Florida International University FIU Digital Commons

$7-2-2014$

\title{
El Posnacionalismo en la Narrativa Cubana Actual: Reivindicación de lo Privado y lo Homoerótico
}

Raul Cabrera

Florida International University, rcabr023@fiu.edu

DOI: $10.25148 /$ etd.FI14071152

Follow this and additional works at: https://digitalcommons.fiu.edu/etd

\section{Recommended Citation}

Cabrera, Raul, "El Posnacionalismo en la Narrativa Cubana Actual: Reivindicación de lo Privado y lo Homoerótico" (2014). FIU Electronic Theses and Dissertations. 1537.

https://digitalcommons.fiu.edu/etd/1537 
FLORIDA INTERNATIONAL UNIVERSITY

Miami, Florida

\title{
EL POSNACIONALISMO EN LA NARRATIVA CUBANA ACTUAL: REIVINDICACIÓN DE LO PRIVADO Y LO HOMOERÓTICO
}

\author{
A dissertation submitted in partial fulfillment of \\ the requirements for the degree of \\ DOCTOR OF PHILOSOPHY \\ in \\ SPANISH \\ by \\ Raúl Cabrera
}


To: Interim Dean Michael Heithaus

College of Arts and Sciences

This dissertation, written by Raul Cabrera, and entitled El Posnacionalismo en la Narrativa Cubana Actual: Reivindicación de lo Privado y lo Homoerótico, having been approved in respect to style and intellectual content, is referred to you for judgment.

We have read this dissertation and recommend that it be approved.

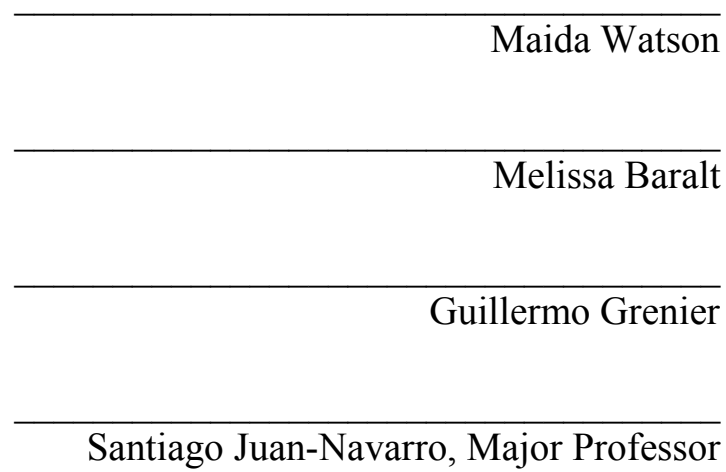

Date of Defense: July 2, 2014

The dissertation of Raul Cabrera is approved.

Interim Dean Michael Heithaus

College of Arts and Sciences

Dean Lakshmi N. Reddi

University Graduate School

Florida International University, 2014 


\section{DEDICATORIA}

A mis padres y a mis hermanos 


\section{AGRADECIMIENTOS}

Este proyecto fue posible gracias a la participación de muchas personas. Me gustaría agradecer a la Dra. Maida Watson por sus sagaces observaciones y carácter desenfadado. Mis reconocimientos para la Dra. Melissa Baralt por su constante apoyo y curiosidad insaciable hacia el tema de la literatura cubana contemporánea. Vayan mis elogios al Dr. Guillermo Grenier por sus valiosas sugerencias y por mantener la puerta siempre abierta a pesar de mis intempestivas visitas a su oficina. Quiero expresar mi gratitud a la Dr. María Asunción Gómez por sus palabras de aliento e infatigable trabajo al frente del departamento. Mi mayor agradecimiento al Dr. Santiago Juan-Navarro, un magnífico catedrático y excepcional ser humano a quien tuve el privilegio de tener como director de tesis y profesor.

Quiero hacer extensivo mi agradecimiento a mis compañeros de clases y amigos que se desvelaron revisando una y otra vez el manuscrito sin desmayar: Alejandra, Cielo, Erja, Eloy, Griselda, Linet, Marilyn. Ellos compartieron muchas jornadas conmigo discutiendo sobre el apasionante tema del posnacionalismo y sugiriendo ideas para enriquecer el trabajo. Es imprescindible agradecer a Marie Guiribitey por su constante amabilidad y por facilitarme horarios de clases flexibles cuando lo necesité. Agradezco también a Jackie, Melissa, Christine y Ketty por el apoyo logístico brindado en todo momento. Finalmente, mi más sincero agradecimiento es para mi hermano Francisco. Gracias a sus ideas, a sus sugerencias y a las muchas horas que dedicó a revisar el manuscrito y a recopilar información este trabajo pudo completarse en tiempo relativamente breve. 


\title{
ABSTRACT OF THE DISSERTATION \\ EL POSNACIONALISMO EN LA NARRATIVA CUBANA ACTUAL: REIVINDICACIÓN DE LO PRIVADO Y LO HOMOERÓTICO
}

\author{
by
}

Raul Cabrera

Florida International University, 2014

Miami, Florida

Professor Santiago Juan-Navarro, Major Professor

La novela posnacional es un fenómeno relativamente reciente en la literatura latinoamericana. Sus orígenes se sitúan en los noventa, como parte de una narrativa que se rebela contra la llamada literatura del Boom originada en los sesenta. Los escritores posnacionales — a diferencia de sus predecesores_ — no se muestran obsesionados por la identidad latinoamericana. La globalización, el fracaso del socialismo y el descrédito de las grandes utopías son otros fenómenos que explican la emergencia de una narrativa que trasciende los márgenes nacionales.

El posnacionalismo cubano se inserta dentro de esta corriente. Luego de la caída del Muro de Berlín, los jóvenes escritores cubanos comienzan a incluir una retórica diferente en sus creaciones: eluden el compromiso político militante, evitan los mensajes altruistas y abandonan las pretensiones de definir posiciones con relación al futuro de la patria o a su propia identidad. El proyecto revolucionario y su destino-tópico narrativo por más de tres décadas - desaparece como tema. El modo particular de la literatura posnacional cubana se expresa en la desesperanza y el desencanto. 
El propósito de esta disertación es ejemplificar dicha noción a través del análisis de los proyectos literarios de tres escritoras cubanas contemporáneas: Ena Lucía Portela, Anna Lidia Vega Serova y Karla Suárez. Además de sus cuentos, se analizan las novelas "Djuna y Daniel”, de Ena Lucía Portela; “Ánima fatua”, de Anna Lidia Vega Serova y "La viajera" de Karla Suárez. Estas novelas, además de ser ejemplos de la existencia en Cuba de una tradición en la narrativa latinoamericana contemporánea desvinculada de las preocupaciones nacionales, rompen con el paradigma del hombre heterosexual revolucionario. Los protagonistas de estas nuevas ficciones, por lo general mujeres, son personas desarraigadas y alejadas de la sociedad, ocasionales consumidoras de estupefacientes y que practican relaciones homosexuales. La transgresión de los estereotipos de género y de los comportamientos heteronormativos se convierten en un instrumento de dinámica posmoderna que presenta nuevos códigos y supone un desafío a los principios tradicionales del modelo revolucionario. 


\section{ÍNDICE}

CAPÍTULO

PÁGINA

INTRODUCCIÓN

I. LA NARRATIVA CUBANA DE LO NACIONAL A LO POSNACIONAL. FORMACIÓN DEL PENSAMIENTO NACIONAL. PRIMERA ETAPA

I.1. Antecedentes

I.2. Formación del pensamiento nacional. Primeros artífices de la nacionalidad

I.3. Acercamiento hacia una definida pertenencia nacional. Patria, destierro y cubanía

I.4. La primera novela cubana: "Cecilia Valdés"

I.5. Polémica en torno a la anexión y la esclavitud. Liberalismo, reformismo y autonomía

I.6. Independencia y soberanía en José Martí

36

I.7. Modernismo, nihilismo y cosmopolitismo. Casal y Varona

42

I.8. Conclusiones parciales

II. LA NARRATIVA CUBANA DE LO NACIONAL A LO POSNACIONAL. SEGUNDA ETAPA

II.1. El telos insular en Lezama y Piñera. El discurso grave de Vitier

II.2. La tríada Nacionalismo, Revolución y Cubanía (1959-1971).

Interludio marxista-leninista (1971-1992)

II.3. Poscomunismo cubano. Mitos y realidades (1992 -Actualidad).

76

II.4. Conclusiones parciales

III. LA TRANSICIÓN A NUEVAS FORMAS ALTERNATIVAS Y SU INSERCIÓN EN EL CONTEXTO LATINOAMERICANO ACTUAL. POSNACIONALISMO

III.1. La aproximación alternativa a los orígenes del canon: Zequeira. Heredia. Martí y Casal

III.2. Los nuevos contornos literarios en la narrativa nacional actual

III.3. Conclusiones parciales

IV. LA PEREGRINACIÓN DEL HOMOEROTISMO: DEL DOLOR A LA EXPLOSIÓN. CARRIÓN, CATÁ, MONTENEGRO, LEZAMA, PIÑERA, ARENAS, PAZ. . BOOM

IV.1. Posnacionalismo y el destape del homoerotismo. ¿Una nueva incorporación al canon?

IV.2. ¿Quiénes somos? La educación sexual bajo control

IV.3. Homoerotismo en la pantalla grande

IV.4. Nosotras (muchos más que) dos 
IV.5. El régimen contraataca 147

IV.6. Conclusiones parciales 150

V. ANNA LIDIA VEGA SEROVA ENTRE DOS AGUAS.

EL DESARRAIGO Y LA IRREVERENCIA DE LA ESCRITURA 153

V.1. Biografía. Obras. Reconocimientos 158

V.2. Bad painting y escribiendo bien. El comienzo del juego 166

V.3. Desde la intimidad. Viñetas y notas al pie. El sexo, el desatino y la marginalidad 168

V.4. Serova y lo posnacional 173

V.5. La fragmentación del alma que pena en el vacío. El desarraigo de la identidad 175

$\begin{array}{ll}\text { V.6. Conclusiones parciales } & 182\end{array}$

VI. KARLA SUÁREZ, DONDE HABITA EL VACÍO. LA BÚSQUEDA DE SU CIUDAD 185

VI.1. Biografía. Obras. Reconocimientos 191

VI.2. Silencios. El interés por el yo y lo cotidiano. La otra feminidad 194

VI.3. De Carroza para actores a Fin de siglo. Del carnaval a la decepción 199

VI.4. La viajera. Antecedentes. Las nostalgias y las añoranzas 205

VI.5. Conclusiones parciales 212

VII. LA RUPTURA CON LO FORMAL EN ENA LUCÍA PORTELA. CON

LAS ALAS ROTAS ... PERO VOLANDO LEJOS Y ALTO 215

VII.1. Biografía. Obras. Reconocimientos 223

VII.2. Siempre una extraña entre las piedras. Djuna en Nueva York 226

VII.3. Antes de Djuna en París. Ena en La Habana 229

VII.4. Adiós a la nación. El desplazamiento del imaginario 234

VII.5. La formidable Barnes. El bosque de la noche 239

VII.6. Conclusiones parciales 242

$\begin{array}{ll}\text { CONCLUSION } & 244\end{array}$

$\begin{array}{ll}\text { OBRAS CITADAS } & 248\end{array}$

VITA 


\section{INTRODUCCIÓN}

A partir de la década de los ochenta, dentro de la relativa estabilidad política y económica que vivía Cuba, muchos jóvenes escritores, nacidos después del triunfo de la Revolución y educados dentro de esta, comienzan a romper con los esquemas tradicionales implantados por el modelo marxista-leninista. Esta avanzada literaria es criticada por los medios de difusión cultural de la isla, pues destapa por primera vez en la aventura socialista temas apartados y censurados hasta el momento. Por ejemplo los fraudes en las becas, el deterioro del compañerismo y las relaciones entre individuos, el machismo, la injusta cruzada homofóbica y los hasta entonces disimulados traumas psicológicos y físicos de la participación de Cuba en los conflictos bélicos de África. Estos jóvenes autores renuevan el quehacer literario en cuanto a temática y estilo, poblando el vacío gris que desde hacía un decenio existía en la expresión poética nacional. El desafío a los patrones literarios imperantes evade los tonos morales o didácticos presentes hasta entonces.

Un giro más llega en los noventa. El desmoronamiento del campo socialista, no por esperado menos dramático, tuvo un enorme impacto en todos los aspectos de la vida del país: económico, político-ideológico, social y cultural. La llamada literatura de la Revolución, que durante treinta años de régimen comunista había predominado, se ha quedado sin asideros. El "hombre nuevo" brilla por su ausencia, ${ }^{1}$ y la distancia que se

\footnotetext{
${ }^{1}$ El llamado hombre nuevo fue el concepto usado para referirse a los seres humanos que crearía la Revolución: seres ideales, carentes de intereses materiales y dedicados a la construcción del socialismo. Ernesto "Che" Guevara en su ensayo "El socialismo y el hombre en Cuba" es quien primero aplica el término a la realidad cubana: "Para construir el comunismo, simultáneamente con la base material hay que hacer al hombre nuevo" (2).
} 
produce entre la realidad del pueblo y la realidad "oficial" que se había logrado imponer se hace insoportable. El discurso y la retórica gubernamental agotan su poder de convocatoria.

Estas experiencias coinciden—según Margarita Mateo Palmer—con las ideas puestas en circulación acerca del fracaso de los grandes relatos ("La narrativa cubana" 53). En estos crudos y desesperanzados nuevos tiempos, los "hombres nuevos" que los "nuevos escritores" van a reflejar son seres marginales dentro de un mundo alienado. La literatura comprometida y pedagógica enfocada hacia lo social, propia de los primeros años de la Revolución, cede paso a otra desencantada y nihilista con tendencia a la introspección, que pone el acento en el individuo. ${ }^{2}$ En los noventa comienza la euforia del desencanto - como la llama Rafael Rojas — en abierta contraposición a la década de la euforia del apoyo a la Revolución que se vivió luego de la toma del poder en 1959 ( $E l$ estante vacio 24). En resumen, señala Ana Chover Lafarga, se observa "la experimentación del orden ideotemático y la representación de personajes y temas hasta entonces inexistentes" (22), que serán explorados bajo formas narrativas poco explotadas en la literatura nacional como son la intertextualidad, la fragmentación, la abstracción, el anacronismo, el uso de la ironía y el sarcasmo.

Se parte de la tesis de que los autores cubanos, para ser integrados al canon nacional, han debido supeditar sus obras a la causa mayor de la Revolución y la Patria. Con la embriaguez que acompañó al triunfo revolucionario se creyó por muchos años concretada, amén de ser impuesta por decreto en los documentos oficiales, la utopía de la

\footnotetext{
${ }^{2}$ El antecedente de este tipo de creación literaria es el llamado realismo socialista, en el cual el objetivo fundamental de la obra era comunicar un "mensaje social" y donde se recreaba un mundo idílico de proletarios y campesinos y se ignoraban los problemas generados por ese sistema.
} 
ideología marxista, con su inherente homogeneización política y social. Los parámetros de la identidad nacional, por su parte, se esforzaban por encumbrar la supremacía del hombre heterosexual y revolucionario como paradigma.

Cuando la inoperancia del proyecto comunista desemboca en el descalabro, con el escepticismo y la desilusión que lo acompaña, se cae en la utopía del desencanto, definida por Jorge Fornet como la aparente despreocupación de los escritores de los noventa por el proyecto revolucionario y su destino. ${ }^{3}$ Ahora el individuo, desconectado de repente del área a la que estuvo conectada por tres décadas, habitante de un espacio y un tiempo imprevistos, y en las antípodas del esquema delimitado por los fundadores del Estado revolucionario, empieza a comulgar con un discurso transgresor y se aparta de los parámetros imaginativos hasta entonces exigidos como los únicos válidos. Emergen modos de vida y actitudes históricamente excluidos de la creación literaria, así como los contenidos se salen del espacio físico nacional. Entre los contenidos que se agregan a la narrativa de ficción a partir de esa década podemos mencionar la dura crisis económica, la prostitución, el mundo de las drogas, el SIDA, las salidas ilegales del país, etc., temas todos propios del desencanto, el pesimismo y la amargura de la época, con sus personajes agónicos y marginales.

Además de los argumentos antes mencionados que salen a la palestra en esta década, es el erotismo otro tema que inicia un camino ascendente, destacando dentro del mismo el de contenido homosexual. Se reivindica el cuerpo, lo íntimo y lo privado en oposición a lo social, a la vez que se comienza a superar la imagen homogénea y

\footnotetext{
${ }^{3}$ Véase el ensayo de Jorge Fornet Los nuevos paradigmas. Prólogo narrativo al siglo XXI. La Habana: Letras cubanas, 2006.
} 
heterosexual que había prevalecido en la narrativa hasta entonces. De aquí parte la hipótesis principal de esta disertación: la literatura cubana contemporánea (finales del siglo XX y principios del XXI) es una literatura marcada por lo posnacional.

El modo particular de la literatura posnacional cubana se expresa en la desesperanza y el desencanto como resultado del agotamiento de la utopía revolucionaria. Hay un desentendimiento total de la estética revolucionaria impuesta por la ideología oficial nacionalista. Más que a través de una oposición frontal contra el sistema, estos nuevos escritores identificados como posnacionales, se limitan a sobrevivir en los márgenes o sitúan sus historias fuera de los límites de la isla, así como fuera del tiempo de la Revolución.

La aparición frecuente del componente homoerótico en las narraciones, a veces central, en ocasiones secundario, es la demostración más clara de que para el escritor posnacional ningún tema humano le es ajeno. Si el papel de la mujer ha sido históricamente el de obediencia y subordinación al hombre, y si la homosexualidad ha significado ser diferente con el riesgo del rechazo social, la demostración última de literatura posnacional será la que tiene como protagonista a la mujer lesbiana. No obstante, es bueno aclarar que lo homoerótico no se reivindica en esta literatura como un derecho tantas veces' denegado por el que hay que luchar, sino que se manifiesta como uno más entre otros de los motivos de inspiración de estos nuevos narradores.

En la apoyatura teórica de este estudio Jorge Volpi tendrá una considerable importancia, sobre todo los ensayos recogidos en su libro El insomnio de Bolivar (2009). Allí explica cómo los jóvenes escritores latinoamericanos (nacidos a partir de 1960), a diferencia de lo que ocurrió con la generación de sus padres (dedicados revolucionarios y 
militantes apasionados), desconfían del orden institucional, se apartan completamente del sistema y son indiferentes a los temas de índole social o pública, interesándose solamente en sus cotidianas experiencias individuales.

El trabajo de Bernat Castany Prado Literatura posnacional: Latinoamérica. Un estudio de caso (2006) tendrá un peso teórico importante. La literatura, de acuerdo con Castany, ha tomado la delantera con respecto a las ciencias sociales y ha tratado de encontrar soluciones propias que manifiesten la irreducible complejidad del mundo globalizado de hoy. A pesar del crecimiento de las interdependencias entre las culturas y las sociedades en el último siglo, las identidades colectivas e individuales son todavía pensadas y establecidas teniendo en consideración modelos nacionales obsoletos.

El investigador Walfrido Dorta Sánchez aporta el concepto de la productividad ideológica que aplicamos en esta investigación. Según este crítico la (in)visibilidad, es decir, la marginalidad o centralidad en los paradigmas críticos de ciertos textos literarios dependen de su productividad ideológica, a saber, la capacidad que tienen para sostener determinados programas narrativos críticos, según las axiologías que articulen esos paradigmas. ${ }^{4}$ De ahí se entienden los ajustes o tachaduras a los que son sometidos para que se reconcilien con una narrativa crítica preestablecida.

El historiador de las ideas y ensayista Rafael Rojas será frecuentado y citado in extenso en este trabajo, en especial por sus aportes al pensamiento crítico para repasar la política y la cultura contemporáneas en Cuba. Entre otras, se recoge su tesis acerca del concepto de la cubanidad como construcción cultural histórica, por lo tanto invención

\footnotetext{
${ }^{4}$ El concepto de productividad ideológica que seguimos en esta tesis es desarrollado por Dorta Sánchez en su ensayo "Productividad ideológica y canonicidad: sobre 'La Ronda' de Manuel de Zequeira y Arango". LL Journal 7.2 (2012).
} 
cambiante, y no como un mito establecido o categoría política, pues esta última entorpece y fija para siempre de manera arbitraria la relación del pueblo con su pasado. Por tanto, el ingreso a la cultura del propio país no puede estar dado por una convicción política $(E l$ arte de la espera 55). Se repasan de este autor igualmente otros conceptos como el de la sacralización de la figura de José Martí y el arraigo del mito martiano, así como la necesidad de deconstruirlo; el de la vasta tradición afirmativa que ha prevalecido en la escritura de la isla que se ha movilizado contra la diferencia; el del mito de la Revolución ${ }^{5}$ no solo como el resultado necesario e inevitable de la historia nacional, sino su destino último; el de la euforia del desencanto que invadió a la sociedad cubana luego de la caída del Muro de Berlín; el de la subjetividad cultural que se intensifica a partir de los noventa con un nuevo paradigma que propugna las alteridades sexuales, genéricas, religiosas y artísticas e impulsa discursos y prácticas posnacionales, entre otros.

De la mano de Víctor Fowler se realiza una revisión sucinta de la homosexualidad y el homoerotismo en la literatura cubana como tema maldito y marginado. Sus ensayos sobre grandes obras de la narrativa cubana que tienen al cuerpo como centro, sirven para situar el contexto histórico de las obras estudiadas en esta tesis. Se aprovecha de Fowler el tratamiento de un tema tabú, el adentrarse en un ámbito prohibido por su desacato y atrevimiento, para establecer la conexión con el concepto de lo posnacional.

Se establece un orden que comienza con los primeros empeños del devenir intelectual y las tendencias nacionales hasta arribar al análisis de las obras y trayectorias

\footnotetext{
${ }^{5}$ Mientras no se especifique lo contrario, en este trabajo utilizaremos el término Revolución (con mayúsculas) para referirnos indistintamente al régimen político, es decir el Estado y sus instituciones, que ha fungido en Cuba desde 1959 hasta la actualidad, bajo el poder de Fidel Castro primero y de su hermano Raúl a partir de 2008.
} 
de tres escritoras contemporáneas de renombre: Ena Lucía Portela, Anna Lidia Vega Serova y Karla Suárez. Los capítulos dedicados a cada una de ellas se centran especialmente en aquellas novelas más relevantes en relación con el tema de esta tesis: Djuna y Daniel, Ánima fatua y La viajera, respectivamente. Estas novelas son ejemplos de la existencia en Cuba de una tradición en la narrativa latinoamericana contemporánea desvinculada de las preocupaciones nacionales. En ellas se promueven actitudes cosmopolitas e individuales, similares a las practicadas por otros escritores latinoamericanos. Las une además el hecho de haber logrado no solo publicar, sino también llamar la atención de la crítica especializada dentro y fuera de la isla.

Mediante el estudio de la obra de estas autoras (sin dejar de traer a colación otros creadores contemporáneos que apoyan esta investigación), se devela cómo en la narrativa insular el concepto de Nación-Revolución se debilita hasta prácticamente desaparecer ya que el lenguaje, los temas y la construcción de los personajes, desconocen lo nacional y sugieren en cambio una alternativa de ruptura. De similar manera, se analiza el tratamiento de la subjetividad homosexual $\mathrm{u}$ homoerotismo en las obras de estas autoras para intentar demostrar que el concepto Nación-Masculinidad-Heterosexualidad es desafiado para reescribir y revisar los límites de la nación. Es decir, el sujeto homosexual se abre paso e inscribe en el espectro de identidades que la nación debe abarcar, ensanchando así sus posibilidades.

El análisis es acometido de manera cronológica. Las ideas que se discuten son aquellas beneficiadas por el designio nacionalista revolucionario en Cuba a lo largo de las sucesivas etapas (colonial, republicana, socialista y poscomunista) propias de la tradición afirmativa, así como las que se presentan como sus contrapartidas o 
alternativas, y que confluyen en el posnacionalismo. Algunas de las convenciones con que la crítica tradicional ha encasillado la producción literaria, son respetadas y separadas por épocas, en aras de una mejor comprensión de la evolución literaria nacional, hasta llegar a las más novedosas tendencias surgidas a finales del siglo XX. Se analizan los antecedentes de la literatura cubana para demostrar que no todo lo post-, incluyendo el posnacionalismo, desfigura la condición nacional.

Con la literatura posnacional se comienzan a superar los eslóganes enarbolados a partir de supuestos "intereses patrios" que suplantan el verdadero cometido literario, habiendo conseguido establecer en el imaginario de la nación cubanidad, cubanía y revolución como conceptos indistintos. ${ }^{6}$ Como bien apunta Rafael Rojas: "Lo revolucionario o lo comunista no pueden concebirse como un rasero para medir cuán cubano es un intelectual. Severo Sarduy y Guillermo Cabrera Infante pertenecen tanto a la cultura nacional como Roberto Fernández Retamar y Lisandro Otero" (El arte de la espera 55). Esta tesis se hace eco de la metodología de Mabel Moraña, cuando señala que "más que la nación como unidad significante y unificadora se estudian sus fronteras y márgenes, y los estratos que la atraviesan como espacios de tránsito cultural y producción de significados heterogéneos y cambiantes que se realizan. . . a través de diversos sistemas de adscripción cultural” (186).

\footnotetext{
${ }^{6}$ Conviene aclarar que en este trabajo los términos lo cubano, cubanidad y cubanía se utilizarán de manera intercambiable mientras no se indique lo contrario. Fue el estudioso cubano Fernando Ortiz en su ensayo "Los factores humanos de la cubanidad" (1940) quien primero intentó establecer una distinción entre ambos vocablos: "Pienso que para nosotros los cubanos nos habría de convenir la distinción de la cubanidad, condición genérica de cubano, y la cubanía, cubanidad plena, sentida, consciente y deseada; cubanidad responsable, cubanidad con las tres virtudes, dichas teologales, de fe, esperanza y amor" (3). Veánse "Cultura, cubanidad y cubanía" de Abel Prieto y "A Willingness of the Heart: Cubanidad, Cubaneo, Cubanía" de Gustavo Pérez-Firmat para más información sobre este tema.
} 
La complejidad y los desafíos que plantea el tema del posnacionalismo, así como lo novedoso e inexplorado del mismo son tan formidables que lamentablemente reducirán el esfuerzo investigativo a una aproximación. Interesa dejar claro además que, como en todo ejercicio académico, se tiende a simplificar lo que en la convulsa y rica realidad cubana es un "ajiaco" de posts- y de -ismos que coexisten. ${ }^{7}$ En el presente estudio se evitará caer en lo que Roberto González Echevarría reprocha a ciertos sectores de la crítica literaria, los cuales se dedican a "cacofónicas parrafadas de pseudofilosofía. . . y se adhieren a diversos "posts": postcolonialismo, postmodernismo, etc., con la ingenua ilusión, muy del marketing norteamericano, de que el próximo "post" será algo realmente nuevo, radical, que borrará todo lo anterior y lo sustituirá" ("Cien años de soledad cuarenta años después"). Nada más lejos del propósito de este trabajo. Aclarado esto, disertaremos a continuación sobre la literatura posnacional en Cuba, intentando identificarla, describirla y conceptualizarla.

El esquema organizativo transitará por los antecedentes de la literatura nativa, tanto por aquellas vertientes defensoras de una entidad "nacional", como por aquellas que la evitan a toda costa. Se pretende demostrar que no todo lo que escribe un cubano se refiere directa o indirectamente al terruño, ni se recubre de estrategia, abierta o velada, para parlamentar sobre las deplorables condiciones de vida en la isla, el fin de la Revolución o cuanta homofobia queda por vencer. Interesa exponer por el contrario, la tendencia cada vez más abierta y amena en la cual el autor posnacional (casi siempre "la"

\footnotetext{
${ }^{7}$ Ajiaco es el nombre popular en Cuba que identifica una sopa que mezcla carnes con vegetales y verduras de diferentes tipos y procedencia, algunas de la cultura indígena cubana y otras traidas por los españoles, los negros africanos y los chinos.
} 
autora), se mueve en las particularidades de su mundo interior plagado de conflictos y desánimos, sin necesidad del auxilio de doctrina política alguna.

Las reflexiones de este trabajo igualmente están encaminadas a mostrar que aunque en los momentos actuales el péndulo de la crítica y la creación literarias, tanto a nivel latinoamericano como vernáculo, se encuentra oscilando hacia el punto de mayor alejamiento del nacionalismo, nada nos garantiza que no vuelva a él. Así, cuando se habla del nacionalismo como algo superado, debe entenderse que se trata de una cosmovisión que ha dejado de ser acatada por la mayoría de los creadores y estudiosos, pero no que carezca de adeptos y seguidores, y mucho menos que haya sido descartada. Sirva de ejemplo la recuperación vigorosa de una retórica nacionalista martiana adornada con ribetes religiosos, resucitada a partir de los noventa luego de tres décadas de oficialismo marxista-leninista en los que se persiguieron las ideas religiosas. Armando Hart Dávalos en su ensayo “José Martí: la tradición ética de la nación cubana”, no solo pone sobre el tapete la sensibilidad cristiana de Martí cuando recoge una célebre frase del "Apóstol” de la independencia: "En la cruz murió el hombre un día: pero se ha de aprender a morir en la cruz todos los días" y exigir de esta manera más sacrificio y entrega a la "causa revolucionaria". Llega incluso a la temeridad de incorporar a Fidel Castro como seguidor de la moral cristiana cuando en fecha reciente cita anacrónicamente las palabras del dirigente cubano en uno de sus discursos a raíz de la toma del poder: "Quién traiciona al pobre, traiciona a Cristo" (Hart Dávalos, “José Marti”").

\footnotetext{
${ }^{8}$ Armando Hart Dávalos (1930) es el actual Director de la Oficina Nacional para el Programa Martiano y de la Sociedad Cultural José Martí. Fungió como Ministro de Educación desde 1959 hasta 1965, y desde 1976 hasta 1997 se desempeñó como Ministro de Cultura.
} 
El primer y segundo capítulos de esta tesis ofrecen una visión general de la génesis y desarrollo del discurso nacionalista desde sus orígenes en el siglo XIX hasta nuestros días. El propósito es mostrar el uso práctico que se ha hecho en la historia literaria de conceptos como cubanía, revolución, patriotismo, y canon cubensis, entre otros. Se ilustrarán las subjetividades que subyacen en el enfoque nacionalista, con la intención de demostrar que el canon implantado por el discurso crítico oficial es la consecuencia de explotar al máximo la productividad ideológica de algunos programas narrativos de nuestras figuras cimeras, en detrimento de otras lecturas.

Se recorrerá la formación del pensamiento nacional en el siglo XIX, comenzando por Manuel de Zequeira y Arango, quien inaugura el canon cubensis por el lado oficial, pero quien también viene a ser una de las fuentes de la que beberá la vertiente alternativa; luego se comentará brevemente la relevancia de José María Heredia como primer ejemplo de la explosión de la obra poética insular hacia un universo internacional y precursor del ejercicio de la palabra poética como estandarte de las ideas independentistas será tratado en el siguiente apartado, para posteriormente presentar a José Antonio Saco López Cisneros, quien fue uno de los pioneros en el acercamiento al concepto de identidad nacional, oponiéndose tanto a la subordinación española como a la corriente anexionista a favor de los Estados Unidos. Se repasa la figura de José Martí por la importancia fundamental que para la política y cultura cubanas continúa siendo su referencia, pero a quien no necesariamente se venera incondicionalmente. Ensayistas recientes se han acercado a la figura y la obra del hombre y escritor que fue Martí soslayando su imagen mítica. Se pasa luego al estudio de una figura que puede entenderse como el reverso de la de Martí: el poeta y ensayista modernista Julián del 
Casal, quien nos revela que ser cubano puede ser mucho más rico y complejo, y también ir más allá que ser patriota revolucionario.

En el segundo capítulo se pasa revista a Orígenes y a la rebeldía existencial de Ciclón, dos maneras contrapuestas de entender el telos insular, representados en José Lezama Lima y Virgilio Piñera respectivamente. ${ }^{9}$ La segunda parte del segundo capítulo abarca el período a partir del triunfo de la Revolución en 1959 hasta la actualidad. Como expresara el cantautor Carlos Puebla en una famosa tonada, con la llegada de los revolucionarios a La Habana "se acabó la diversión, llegó el comandante y mandó a parar". Es el momento a partir del cual se desatan las grandes utopías de la construcción del socialismo cubano y de la creación del "hombre nuevo" imaginado a imagen y semejanza del "Che". El fervor nacionalista deviene una radicalización doctrinaria de la cultura en general, y de las letras en particular. Del intelectual como conciencia crítica de la sociedad en la República y en los inicios de la Revolución, se pasa al requerimiento del intelectual "revolucionario" como contribuyente a la "obra común" de la construcción socialista y no como conciencia crítica frente a ella.

Con la caída del Muro de Berlín, Cuba entra en los noventa en una bancarrota económica, política, ideológica, social y moral. El debilitamiento del sustrato doctrinal marxista-leninista, y de su transmisión a través de los aparatos ideológicos del Estado se ve compensado por una inflamación de la retórica nacionalista. En una sociedad en profunda crisis, los escritores cubanos buscan nuevos retos donde abrirse y abrir al país.

\footnotetext{
9 Orígenes (1944-1956) fue una publicacion cultural dirigida por José Lezama Lima y José Rodríguez Feo. Se publicaron cuarenta números y salía trimestralmente. La revista Ciclón (1955-1957) fue fundada por José Rodríguez Feo luego de la ruptura de este con Lezama Lima. Salieron trece números. Ambas fueron defensoras de "un reducto de la alta cultura conquistada por y para minorías" (Lobato Morchón 75).
} 
Se desata una corriente de autores que no teme tratar explícitamente un tema tabú como la sexualidad (y especialmente la homosexualidad) y que, mediante un lenguaje sucio y profano, rediseña la estructura y los conceptos sobre la sociedad y sus patrones que por más de un siglo habían prevalecido.

En el tercer capítulo se examinan las propuestas que en los ámbitos prácticos, teóricos y estéticos explican el surgimiento, desarrollo y auge del fenómeno posnacional en Cuba, especialmente en la narrativa de ficción. El tránsito a nuevas formas alternativas en la literatura cubana actual se debe a varios factores. Uno de ellos es la transformación social y, con ella, la transformación de las viejas formas de relación humana que han afectado a los países occidentales desde mediados del siglo XX. ${ }^{10}$

Otro factor no menos importante es la globalización, fenómeno que abrió una profunda crisis en la cultura y el conocimiento, y trajo a su vez una honda crisis de criterio y con ella la necesidad de replantearse conceptos modernos como los de EstadoNación, ciudadanía e identidad. A lo anterior se suma el desmoronamiento del socialismo real y el descrédito de las utopías, aspectos que han influido en la manera en que los escritores, en especial los nacidos a partir de 1960, desarrollan su escritura: a diferencia de sus predecesores, ninguno de ellos se muestra obsesionado por la identidad latinoamericana. La narrativa latinoamericana contemporánea de carácter cosmopolita podría enlazarse con el adjetivo de posnacional que se aplica en este trabajo a la narrativa cubana, pues como aquella, también esta rehúsa a ser limitada por sus orígenes

\footnotetext{
${ }^{10}$ La crisis de identidad en las sociedades actuales es de tal envergadura que permite formular al historiador Eric Hobsbawm: "todos los vínculos tradicionales de la comunidad se han evaporado, a excepción de la capacidad más residual o metafórica para definirnos. Todos somos personas desarraigadas" (Identidad" $16)$.
} 
nacionales y busca deliberadamente un lugar de encuentro con otras tradiciones literarias y culturales.

En ese contexto internacional Cuba entra en el "Período especial en tiempos de paz" en los primeros años de los noventa, cuyas características más generales son tratadas en este capítulo. ${ }^{11} \mathrm{El}$ "Período especial", si bien desde el punto de vista económico fue cruelmente duro, trae cambios que beneficiaron a los creadores literarios, pues al deteriorarse el modelo asistencial del Estado, paradójicamente se abren espacios para que los narradores viajen y sean editados en el exterior. En estas nuevas condiciones Cuba se pone "de moda" en el mercado literario internacional y aumenta dramáticamente el interés por parte de los agentes literarios y casas editoriales foráneas, fenómeno que ayuda a que a finales de la década llegue a hablarse de un "new Cuban boom" (Whitfield, Cuban currency 55). Entre los temas que se subrayan, además de la dura crisis económica, se pueden mencionar la drogadicción, el SIDA, o las salidas ilegales del país. Lo privado empieza a destacar en contraste con la dimensión social. Se reivindica el derecho a disentir y al espacio individual.

En este apartado se explica la relación entre la literatura posnacional cubana y el homoerotismo. Se recalca que el repunte o auge de contenido homoerótico en la narrativa, también se está dando (y permitiendo) en otras artes como son el teatro y el

\footnotetext{
${ }^{11}$ Denominación creada por el gobierno cubano para explicar los drásticos recortes a programas sociales y educacionales, nivel económico y en general, la caída abismal de la calidad de vida del pueblo. Se inaugura con el discurso del 28 de enero de 1990, cuando Fidel Castro introduce la frase que luego serviría para designar toda una época: “¿Qué significa 'Período especial en tiempos de paz’? Que los problemas fueran tan serios en el orden económico. ..., tan graves, que nuestro país tuviera que afrontar una situación de abastecimiento sumamente difícil" ("Discurso en la clausura del XVI Congreso de la CTC"). Esta época se cierra extraoficialmente con otro discurso del propio Castro en marzo de 2005: "el 'Período especial' durísimo que vamos dejando atrás" (cit. en Whitfield 159). El país estuvo al borde de un colapso propio de una nación en guerra, exceptuando las acciones s bélicas.
} 
cine. La aceptación social y el apoyo institucional a través de la organización gubernamental Centro Nacional de Educación Sexual (CENESEX) a las demandas de este sector tiene, por otra parte, costos, entre ellos: la pérdida de autonomía y el control del reducto más privado del individuo que es la libre práctica de su elección sexual. Los nuevos narradores a través de una ficción que reniega de los límites nacionales y perciben la nación sin una identidad fija, se adentran en el delicado tema del homoerotismo.

Sin embargo, el homoerotismo, el nihilismo y el desencanto no son exclusivos de la literatura posnacional, los nuevos escritores o la crisis de los noventa. Nuestra investigación recrea cómo en los propios inicios de la literatura cubana la cara oculta de autores canónicos como Zequeira, Martí, Heredia o Casal, si bien tangencialmente, tiene sus vetas homoeróticas. Igualmente, en el siglo XX varios escritores retoman la subjetividad homosexual, entre ellos algunas figuras clásicas o establecidas (varios de ellos solo recientemente están siendo recuperados). De entre todos estos se comenta brevemente la obra de Alfonso Hernández Catá, así como la de Carlos Montenegro, y con algo más de detalle, las de Lezama Lima, Virgilio Piñera, Reinaldo Arenas y Senel Paz.

En los capítulos 5, 6 y 7 se explora la obra de tres jóvenes pero ya renombradas escritoras de la isla: Anna Lidia Vega Serova, Karla Suárez y Ena Lucía Portela quienes revisitan el concepto de pareja y su relación con la sociedad cubana actual. Se les dedica un capítulo por separado a cada una de ellas, en donde se ofrece una visión panorámica de sus obras y características literarias, así como de los puntos en común entre sus poéticas. Las tres transitan por una prosa donde lo homoerótico, la marginalidad y la transgresión protagonizan su quehacer. 


\section{CAPÍTULO I}

\section{LA NARRATIVA CUBANA DE LO NACIONAL A LO POSNACIONAL.}

\section{FORMACIÓN DEL PENSAMIENTO NACIONAL. PRIMERA ETAPA}

El porvenir es de Dios, pero el pasado es de la historia, Dios ya no puede influir en la historia, en cambio el hombre aún puede escribirla y transfigurarla.

Juste Dion (cit. en Padura, La neblina del ayer)

Germán Arciniegas, en Nuestra América es un ensayo dice: “América es ya en sí, un problema, un ensayo de nuevo mundo, algo que tienta, provoca y desafía la inteligencia" (5). Marcando fronteras en el Caribe americano, este primer capítulo estudiará el extenso y profundo debate sobre el nacionalismo cubano, sus mitos, supersticiones y su reflejo literario.

Desde sus inicios, las letras cubanas han estado profundamente politizadas. En nuestros días, el prejuicio a que se encuentran sometidas las obras literarias viene dado principalmente por la censura impuesta a toda manifestación considerada "no oficialista". No obstante, es necesario reconocer que en todas las manifestaciones artísticas, la literatura incluida, han existido iniciativas que no acatan la cuasi obligada cosmovisión nacionalista, y evitan o se apartan de la problemática de la nación como tema. Estas vertientes no se sienten identificadas—ni social ni moralmente—con la interpretación oficialista de la realidad o con los anhelos delimitados por fronteras nacionales.

Mucho se ha discutido en el pensamiento literario y social contemporáneo sobre los nacionalismos latinoamericanos y caribeños, de los cuales el caso cubano es solo un capítulo (importante sin duda) de una historia continental mucho más larga y fecunda. En un estudio más ambicioso podría compararse, por ejemplo, con el caso argentino o mexicano. Ya Silvana Mandolessi advierte sobre cuán incorporado está lo nativo en 
nuestras latitudes cuando enuncia: "El nacionalismo está tan profundamente arraigado en la psicología individual y colectiva, así como en los mismos procesos de producción y conocimiento de la realidad. .., que las identidades individuales y colectivas siguen construyéndose fundamentalmente sobre modelos nacionales, aunque estos resulten caducos" (4).

La literatura fue desde muy temprano, y continúa siendo, uno de los factores más eficaces y activos en la configuración de las identidades nacionales, no solo como instrumento de educación, sino como repertorio de símbolos y espacio de consolidación de las narrativas patrias (Guerrero 75). Con respecto a la poética cubana en específico, el tratamiento del tema en los dos últimos dos siglos, ha sido un discurso y una práctica cultural monopolizados por ciertas élites criollas, sobre todo blancas y mestizas. Estos pensadores han privilegiado un enfoque patriótico revolucionario de la nación sobre otro más abierto y cosmopolita. Aun cuando en las últimas dos décadas el Estado, con la intención de abrir tímidos espacios al desarrollo de relaciones de mercado, ha flexibilizado parte de la gestión burocrática en algunos sectores económicos, todavía "la cultura política pretende definirse desde un nacionalismo cada vez más intransigente. .., con una idea de la nacionalidad que se empeña en identificar históricamente lo cubano y lo revolucionario" (Énfasis añadido, R. Rojas, El arte 53). Imprescindible es advertir entonces el componente extraliterario sobre el que se ha construido el canon poético de la isla: "el canon oficial literario cubensis" - advierte el poeta y ensayista Francisco Morán—, "es un canon ante todo político, y por lo mismo construido a expensas de lo literario. En esto radica su aberración" (Julián del Casal o los pliegues del deseo 25). 
Relacionado con esta cuestión de fijar imágenes, obras y autores que pasan (o no) a engrosar el canon cubensis, y por la importancia que va a tener a lo largo de este estudio, se hace imprescindible introducir el concepto de productividad ideológica, delineado por Walfrido Dorta Sánchez. Para este autor, hay ciertos textos literarios que permiten ilustrar la relación entre discurso literario y discurso crítico a partir de "las tachaduras o ajustes a las que son sometidos, en virtud de lo que podría llamarse su productividad ideológica, a saber, la capacidad que tienen como textos, según las axiologías que articulan esos discursos críticos, para sostener determinados programas narrativos críticos" (1). De esa manera, las tachaduras o ajustes, que podrían llegar a ser desapariciones o apologías admiten, de acuerdo al caso, "la (in)visibilidad de ciertos textos literarios, es decir, su marginalidad o centralidad en los paradigmas críticos” (1).

Lo anterior ayuda a entender mejor el planteamiento de Rafael Rojas cuando señala cómo la escritura de la isla se ha movilizado contra la diferencia en una "vasta tradición afirmativa del ser cubano que se extiende de José Martí a Cintio Vitier”, pasando por Félix Valera, José de la Luz y Caballero y Jorge Mañach (Énfasis añadido, Isla sin fin 106). Es decir, la pertenencia (o no) de textos y autores a la condición de canónicos ha estado ligada a la existencia de una agenda previa condicionada políticamente por aquellos que controlan el aparato cultural. Algunos rasgos específicos en los cuales esta tradición afirmativa ha puesto el acento son: el independentismo, el uso de la violencia como medio de alcanzar fines políticos, el revolucionarismo y el antiimperialismo. Son los representantes de este discurso en Cuba los que predominantemente han pasado a formar parte del panteón literario nacional, sus 
biografías convertidas en hagiografías y sus obras en "bienes nacionales", símbolos de un poder intelectual necesario para la afirmación de la identidad nacional.

A pesar de la preponderancia del nacionalismo afirmativo, ha existido asimismo en el pensamiento de la isla otra variante de nacionalismo, generalmente menospreciada y ninguneada por los que controlan la difusión de la cultura y las ideas. Este discurso alternativo, en oposición al afirmativo (que en la etapa revolucionaria se solapará e identificará con el discurso “oficial”), tiene como principal rasgo su visión irónica y desconfiada de los grandes relatos que forman la nación. A esto habría que sumar una vocación anárquica y una levedad del tono (Del Risco 5). Por último, la autonomía del escritor con relación a las instituciones, y su relativa independencia de los metarrelatos nacionales y los mitos que la sostienen, son otras importantes características del mismo.

A partir de 1959 el gobierno ha favorecido aquella posición mediante la cual el arte ha sido utilizado como un instrumento más dentro del arsenal político del Estado para certificar los valores de la "auténtica cubanía". Morán se refiere a esa intromisión del régimen en la creación artística como "intervención totalitaria de la cultura" (25). Esta intrusión ha demandado la existencia de un "arte revolucionario", concepto que se remoza según la conveniencia o presión política del momento. La posición oficial está ávida no solo de exaltar lo humano del sistema, sino también de ocultar los desaciertos cada vez más profundos del mismo. A la par, trata de soterrar (o atraer a la orilla nacionalista cuando conviene gubernamentalmente) los tinos de aquellos que en desacuerdo con la línea oficial, apetecen un terruño independiente y lo preservan.

Del mismo modo, el régimen ha desestimado a quienes no les importa escribir sobre el pasado, el presente o el futuro de la nación y prefieren adentrarse en temas no 
"oficialistas" como son el universo de la modernidad, el hastío, la sexualidad, etc. Para estos últimos, no hubo prácticamente cabida durante las primeras tres décadas de la Revolución dentro del formato rígido de un Estado nacionalista marxista-leninista. Sin embargo, con el desvanecimiento de las grandes narrativas que acompañó la desaparición de la utopía representada por el socialismo, son precisamente los representantes de la escuela alternativa quienes han adquirido la mayoría de los espacios literarios en donde encajar sus expresiones individuales por tanto tiempo relegadas. Y esto a través de una literatura vibrante y poderosa, pues en la isla se cumplen bien las palabras de Rafael Rojas cuando asegura, "[1]a desilusión teórica que se vive en nuestros días, en vez de restringir la creatividad cultural y política, la desafía y, por tanto, la estimula" (El arte $52)$.

\section{1. Antecedentes}

Ya desde el descubrimiento, empezando con los Diarios de Colón, Cuba “aparece como tema ante una mirada en la que se entremezclan los contornos y caracteres de la realidad con la fabulación" (Historia de la literatura cubana 1:7), y las narrativas que explican la isla se han visto coloreadas por la constante herramienta de la política. Baste tener en cuenta que la nacionalidad se engendró y encontró impregnada por los conquistadores españoles, los negros esclavos africanos, los inmigrantes europeos, chinos, etc., quienes dieron al traste con las aspiraciones del indígena nativo exterminado, tornando un país aislado en una amalgama de tradiciones y yuxtaposiciones multiculturales que resultó en lo criollo. Colón exclama lo bello de nuestras costas en sus escritos enviados con prontitud a la metrópoli, asegurando haber llegado a las Indias, 
instituyendo inmediatamente los intereses ibéricos y trastocando la isla en "sitio para alimentar la imaginación de los peninsulares" (Historia 1:7), y del resto de Europa para siempre.

Los primeros conquistadores y las subsiguientes olas migratorias, junto a los avances tecnológicos de la época—esclavos, alpargatas, cernidores de oro, cepos, piratas, trapiches y hacendados-, introdujeron una irresistible voluptuosidad que permeaba todos los órdenes sociales, y que se convirtió, usando un término culinario popular, en un "ajiaco" de etnias: peninsulares españoles, sus descendientes blancos y criollos, los negros esclavos traídos de África, los mulatos, los contingentes de inmigrantes chinos culíes, gallegos, asturianos y canarios más adelante, fueron conformando lo cubano en la cultura nacional. Es decir, lo cubano en la literatura surge como mezcla de variadas corrientes culturales, influenciadas en un principio por ideas filosóficas, pedagógicas y artísticas provenientes de Europa y Estados Unidos. La formación de la conciencia nacional tiene su origen en el mundo de la cultura, más que en el de la política. Como corrobora Rafael Rojas "toda nacionalidad. . tiene un origen cultural, no político. Cuba fue primero nación y después Estado" (El arte 55).

Entre los siglos XV y XVIII se sedimentan las distintas herencias culturales y aparece lo criollo reflejado en las letras a partir del secuestro del Fray Juan de las Cabezas Altamirano por el pirata galo Gilberto Girón, asesinado luego por el esclavo Salvador Golomón. Esta acción, convertida en poema en 1608 con el título Espejo de Paciencia, pasó a convertirse en el tema central del primer texto acreditado y el único en Cuba de poesía épica renacentista, al estilo de los poemas americanos como La araucana o el Arauco domado. La autoría del poema se le concede a la pluma del escribano del 
cabildo de Puerto Príncipe (hoy Camagüey), de nombre Silvestre de Balboa, canario arribado a puerto cubano a finales del siglo XVI.

La obra se mantuvo oculta o perdida, y no fue hasta 1836 (es decir más de doscientos veinte años más tarde) que el investigador José Antonio Echeverría descubrió los manuscritos en pésimo estado en los archivos de la Sociedad Patriótica de La Habana, entremezclados con otros documentos. No está de más salpicar con un grano de sal esta última observación, pues los originales del supuesto manuscrito nunca han sido encontrados, así como tampoco se conserva la copia que José Antonio Echeverría hiciera del poema. Esto ha tenido a los investigadores y ensayistas enfrascados en interminables discusiones acerca de la veracidad de dicho documento, que bien podría haber sido un tremendo engaño literario. Por ejemplo, el ensayista y poeta Jorge Luis Arcos se resiste a incluir esta obra como parte del canon literario de la isla "en tanto aceptemos la hipótesis de que El Espejo de paciencia fue una invención del círculo delmontino para dotar de un principio coherente, una suerte de Troya tropical, a nuestra literatura" (Énfasis añadido, "Notas sobre el canon" 42). Otro punto a destacar es que si bien en última instancia fuera verídica, vendría a ser la primera obra de literatura escrita en Cuba, no la primera cubana. Querellas aparte, la importancia del poema se ha establecido por su condición de documento fundacional de la literatura de la isla, basado en un hecho histórico concreto e inmediato. En él están la descripción de la naturaleza cubana con sus flores y frutos, conectando además con la tradición renacentista, en una mezcla de elementos mitológicos grecolatinos con la flora, fauna y vestimentas nativas. Como bien apunta Cintio Vitier en su imprescindible recopilación de ensayos Lo cubano en la poesía, en "el desenfado aparejamiento de palabras como Sátiro, Faunos, Silvanos, Centauros. .., con guanábanas, 
caimitos, mameyes, aguacates. .., hicoteas, patios y jutías, se esconde en germen (sin intención ni conciencia del autor, por la sola fuerza de los nombres) un rasgo elemental de lo cubano, y es la suave risa con que rompe lo aparatoso, ilustre y trascendente en todas sus cerradas formas" (cit. en Sarduy, Escrito sobre un cuerpo 69-70). Es decir, lo cubano incluye lo ligero, lo simple, lo intrascendente. Esa "suave risa" que surge de la yuxtaposición de lo heterogéneo.

Vale también destacar la aparición en la narración de los distintos grupos étnicos y económicos de la sociedad de la época, articulando una comunidad de intereses que olvida las jerarquías sociales. Esa relación entre los hechos históricos concretos e inmediatos, así como el carácter popular y colectivo de la acción, ha sido aprovechada por el discurso oficial para acuñar el término "poesía de la participación”, mecanismo que sugiere la existencia en el texto de una voluntad integradora más allá del individuo, lo que refuerza el pensar la nación en términos colectivos. Se arriba así al siglo XIX, momento del comienzo de un verdadero sentimiento nacional.

I. 2. Formación del pensamiento nacional. Primeros artífices de la nacionalidad ¡Oh Cuba mía! ¿Bajaré a la tumba sin verte libre? Anselmo Suárez y Romero (cit. en Bueno xix-xx)

Pretender juzgar a los intelectuales cubanos del XIX por su participación o no en el proceso de lucha independentista es descarriado, aunque habitual en el discurso crítico de la cultura cubana. Ocurre lo mismo cuando se pretende valorar al artista según sus cualidades morales. Es decir, lo estético tiende a quedar supeditado a criterios políticos y morales. Ese ir "más allá arrastra consigo una desestimación del hecho literario 
autónomo- puntualiza Francisco Morán —en favor de las virtudes políticas y morales" (24).

Los escritores cubanos establecen su utopía intelectual en el período colonial como parte de proyectos relacionados con el identitario de la isla y con el imaginario de nación que ellos ayudan a construir. La encrucijada estética entre la disyuntiva de reformistas, patriotas, moderados, independentistas y anexionistas tropezaba con un sector literario de escritores a los que continuar dependiendo de España o pasar a los Estados Unidos no era prioritario. Apetecían antes la expresión sincera de los cotidianos problemas personales y no decidir qué hacer con una Cuba que expandía y desarrollaba la potencialidad y economía criolla, y por ende, las bases para romper el cordón umbilical con la metrópoli. En la década de 1820 la burguesía criolla, fortalecida, comienza sus primeros intentos por emanciparse.

Entre las principales figuras letradas de esta etapa se encuentra Manuel de Zequeira y Arango (1764 - 1846), poeta, ensayista, primer director del diario Papel Periódico de La Havana (entre 1800 y1805), y fundador de El Criticón de La Havana. ${ }^{12}$ Zequeira nació en La Habana, estudió en el seminario San Carlos y luego formó parte de una clase militar instruida, llegando a participar como militar defendiendo los intereses de la corona española, primero contra los franceses en Santo Domingo, y posteriormente contra los independentistas neogranadinos (Historia de la Literatura Cubana 1, 71).

\footnotetext{
12 Papel Periódico de la Havana (1790-1805) fue una publicación periódica creada a partir de los intereses económicas de la sacarocracia criolla. Fundada por Luis de las Casas, a la sazón gobernador colonial, la publicación logró expresar "desde una nueva concepción social de la prensa, una imagen ideológicamente significativa de la sociedad colonial cubana". El Criticón de la Havana fundado en1804 por Zequeira fue importante por sus numerosos artículos de crítica social y de costumbres (Historia de la Literatura Cubana I, 58, 63)
} 
Como recoge la antología Historia de la literatura cubana, "[e]n general ha sido muy controvertida la valoración de cierta 'cubanía' en la obra de Zequeira. .., pero no es menos cierto que. . pueden encontrarse los gérmenes de algunas formas de significar 'lo cubano' en la literatura posterior" (75). Por su parte, Lezama Lima en su Antología de la poesía cubana, considera a Zequeira "el primer poeta cubano en el tiempo, por su calidad y vocación, [y] por el conocimiento estudioso de su instrumento poético" (256).

Zequeira, embrión de lo cubano, inaugura el canon cubensis por el lado oficial, pero paradójicamente también viene a ser la fuente de la vertiente alternativa. Dos poemas ayudan a ejemplificar la afirmación anterior: la bien conocida y estudiada oda "A la piña", por un lado, y el menos citado conjunto de décimas "La ronda. Verificada la noche del 15 de enero de 1808", por el otro. En este apartado, siguiendo el formato general del capítulo, se enfatiza el aspecto de la obra de Zequeira aprovechada por el discurso oficial, representada en este caso por su oda "A la piña", mientras que en el capítulo siguiente se intentará mostrar la cara alternativa de la obra zequeirana. A continuación un fragmento de la oda "A la piña":

Es su presencia honor de los jardines, y obelisco rural que se levanta en el florido templo de Amaltea, para ilustrar sus aras.

Los olorosos jugos de las flores, las esencias, los bálsamos de Arabia, y todos los aromas, la Natura 
congela en sus entrañas.

Y así la aurora con divino aliento

brotando perlas que en su seno cuaja,

conserve tu esplendor, para que seas

la pompa de mi patria. (cit. en Castromori, 17-24, 80-84)

Para Mirta Aguirre, es con ese poema con el cual abren "todas las selecciones antológicas de la poesía cubana al llegar a indiscutida tierra firme", y agrega que "la primera conquista poética cubana es, pues, una conquista frutal" ("Poesía y cubanía" 456). En esta misma línea se ubica Cintio Vitier, quien atribuye al mismo poema "un acercamiento lleno de ternura y donaire a la flora de la isla, precursor velado de emociones patrias más entrañables", y más adelante califica a Zequeira como uno de los anunciadores de José María Heredia (Crítica 1, 3).

El sentimiento patrio se perfila y comienza a manifestarse a través del paisaje, olores, sabores y sonidos. Al final del poema, la piña se convierte, según Vitier, en "símbolo de la isla". Como se observa, el relato teleológico de lo cubano encuentra su principio, aun cuando esto requiera un poco de malabarismo, con este poema. Similar lectura desarrolla Enrique Sainz: "detrás de las alusiones cultas y del ingenuo fervor de un lenguaje hedonista y de una sintaxis de definida simplicidad, hay una devoción criolla que habla por sí misma del sentido de lo autóctono". Y más adelante: "la oposición y alabanza de los dones de la naturaleza cubana frente a los de otras regiones es. . una reafirmación de lo propio, símbolo de una cubanía que habría de madurar con los años" (Énfasis añadido, cit. en Dorta Sánchez 4). De esta manera la oda "A la piña”, sobre todo 
con ese fervoroso final "la pompa de mi patria", desbroza el camino para una interpretación patriótica de la cubanía. Vale referirse de pasada a la no mención por estos mismos críticos, notable por lo insólita, de otra obra mayor del bardo: su poema en décimas "La ronda", el cual se tratará con detenimiento en el próximo capítulo.

Un aspecto digno de mencionar, presente la idiosincrasia criolla desde entonces, es el uso de lo que Vitier refiere como "zumba o chacota", que luego devendría en el conocido "choteo". Otro dato curioso es la tendencia de los versificadores anónimos que escribían para el Papel Periódico de La Havana a cubanizar las fábulas de la literatura universal. ${ }^{13}$ Testimonios de lo anterior vendrían a ser las fábulas "La víbora y el majá", “El tabaco verde y el gusano”, y "La guacamaya, el carpintero y el cao”. De este último se muestra su gracioso comienzo:
Alegres una mañana
se iban paso entre paso
Guacamaya y Carpintero
por un guayabal paseando.
Divisó la Guacamaya, por entre los verdes ramos, una guayaba madura, de nunca visto tamaño. (cit. en Vitier, Crítica 1, 64)

Estas publicaciones empiezan a celebrar los elementos costumbristas en la caracterización del paisaje urbano, sobre una base de fina ironía y velada crítica (Vitier,

\footnotetext{
${ }^{13}$ Cubanizar, de acuerdo con Gustavo Pérez-Firmat "is to make Cuban something that isn't Cuban to begin with, ... cubanizar names the appropiation of the foreign, the reduction of a terra incognita into something as familiar as your own backyard" (5)
} 
Crítica 62-3). Los mencionados, junto a José María Heredia, Plácido o José Martí después, sustentaron la construcción del imaginario de la nación y la identidad de la isla, al menos en las figuras emblemáticas de la literatura neoclásica, romántica y modernista del siglo XIX cubano (Miranda 312).

En las variadas y abundantes publicaciones periódicas del siglo se advierte bajo una gruesa capa de populismo y pintorescos parajes literarios el trasfondo político y la primero velada, y luego abierta, acusación contra el régimen colonial. Sirva como ejemplo la inclusión por Martí de La Ilíada de Homero en el primer número de La Edad de Oro, revista para niños creada y dirigida por él en Nueva York en 1889, coincidiendo con la etapa en que se encuentra enfrascado en la preparación de la Guerra de Independencia desde el exilio. Asimismo, a mediados de 1839, ve la luz el primero de los dos tomos de Cecilia Valdés o La loma del ángel, del escritor y anexionista Cirilo Villaverde (1812 - 1894), considerada la primera novela cubana.

I. 3. Acercamiento hacia una definida pertenencia nacional. Patria, destierro y cubanía

Amar la vida nacional, amarla en todas sus fases históricas, amarla verdadera, profundamente, es condición primera para la dicha y prosperidad del porvenir. La tradición del pensamiento, la herencia de los padres, hay que guardarlas con cuidado y cariño, no divorciándose nunca del pasado. Arturo Farinelli (cit. en Chacón y Calvo 16).

En conferencia en el Instituto de La Habana la noche del 8 de Febrero de 1913, el escritor, periodista y ensayista José María Chacón y Calvo expresa la importancia que le concede a la literatura como instrumento de creación del imaginario nacional, y la conexión del mismo con los ideales de independencia, en los siguientes términos: 
Una literatura genuinamente nacional es uno de los signos más característicos de la unidad étnica de un pueblo.... Se comprende, pues, que la formación de una literatura nacional haya sido uno de los ideales constantes de los pueblos que empiezan a vivir vida propia y de libertad política. ... Por eso todo gran movimiento político de liberación, o de consolidación de la libertad de un pueblo, ha sido siempre precedido de un gran movimiento literario donde se afirma la existencia de ese pueblo con un tipo propio de cultura, con una unidad espiritual clara y definida. (17)

Para comprender el deseo independentista y su primera manifestación nacional, es significativo advertir a su vez que en Cuba, como en el resto de la América conquistada, los "criollos" lo eran a partir de su nacimiento en suelo cubano, aunque hubiesen abierto los ojos a la semana de la migración de su padre desde Canarias o Madrid. Ser criollo en Cuba era una necesaria condena a la subordinación, aunque se hablase castellano, se fuese católico y descendiente directo de españoles (Anderson 92). Por otra parte, un criollo no tenía que temer al exterminio físico, o el sometimiento a la condición de esclavo. Los criollos tampoco eran masacrados como los indios nativos ni tiranizados como los esclavos traídos de África y sus descendientes. Una gran mayoría de los latifundistas criollos eran blancos, por lo general católicos e intelectuales, y se convirtieron en los mediadores necesarios para que la metrópoli dispusiera de la riqueza económica de las colonias occidentales. Explorar Latinoamérica por un cubano oriundo era pasearse por provincias de la madre patria (Anderson 266).

La obra poética de José María Heredia (Santiago de Cuba 1803 - México 1839) rompió con la tradición de la lengua española, incluso en la propia urbe, dominada 
entonces por un neoclasicismo de diversas gradaciones. La dimensión continental del primer gran poeta romántico y exiliado cubano, quién también fue ensayista y dramaturgo, llevaría al romanticismo a su verdadera dimensión. Heredia es el primer ejemplo de la explosión de la obra poética insular hacia un universo internacional y el precursor del ejercicio de la palabra poética como estandarte de las ideas independentistas. Fue además el ejecutor, junto a su logia, del primer estandarte originario, la bandera de los soles y rayos de Bolívar. Heredia es el primogénito de un acercamiento patriótico definitivo y de la añoranza eterna hacia el terruño patrio.

Es en estos aspectos de su creación poética donde pone el acento una vertiente de la crítica oficial en Cuba, siempre pronta a descubrir y destacar lo que de político y épico se pueda encontrar en el arte. El revolucionario y el patriota se despliegan en la poesía herediana en poemas como "Vuelta al Sur", "La estrella de Cuba", "A Emilia", y en el bien conocido "Himno del desterrado”: “ ¡Dulce Cuba! en tu seno se miran / En su grado más alto y profundo, / La belleza del físico mundo, / Los horrores del mundo moral" (cit. en Padura, José María 143). Ejemplo seguido por Nicolás Guillén, arquetipo del poeta nacionalista que reacciona contra la dominación económica norteamericana de la isla, quien con el mismo tono escribe en 1947: "Mi patria es dulce por fuera, / y muy amarga por dentro; / mi patria es dulce por fuera, / con su verde primavera, / y un sol de hiel en el centro" (204). Versos que hacen evocar, una vez más, aquellos otros del "Himno del desterrado" de Heredia antes citados.

Heredia es el primer poeta cubano—-de acuerdo con Vitier—más que todo por "[e]sa profunda y delicada identificación entre sus ideales, entre su vida emocional y sus convicciones políticas" (Énfasis añadido, Crítica 1:4). Este Heredia político, tornadizo y 
azaroso, ha centrado la atención de sus cronistas. Parece que el "torbellino

revolucionario" de la vida y obra del poeta, le apartaba de todo lo que no se refiriera a la liberación de los pueblos. Sin embargo, Heredia es también el abanderado del desencanto ante la realidad política de la isla. En México, bajo una desilusión análoga a la de su héroe Simón Bolívar, escribe una composición poética que desde su título "Desengaños" lo indica todo: "de mi Patria los ojos un momento / atraje sobre mí... ¡Delirio insano!... / de la vana ambición desengañado, / ya para siempre abjuro/ el oropel costoso de la gloria, / y prefiero vivir simple, olvidado, / de fama y crimen y furor seguro" (Heredia 92).

\section{4. La primera novela cubana: "Cecilia Valdés"}

El desarrollo de la industria azucarera en Cuba trajo consigo la oleada africana hacia la isla como mano de obra esclava. El tiempo produjo inexorablemente el mestizaje, producto de la violencia entre el colono español y la negra esclava africana, nuevo prototipo erótico para criollos y peninsulares. Cirilo Villaverde en su novela Cecilia Valdés o La Loma del Ángel destaca los atributos de la mulata para imprimirle un acentuado carácter racial por el desborde de la sexualidad femenina, en un mundo que según los críticos el autor conocía muy bien, pues residió sus primeros años de vida en el ingenio familiar, en donde estaba vigente el sistema esclavista, institución que llegó a odiar profundamente.

Villaverde publicó sus primeras obras en la revista Miscelánea, asistió con asiduidad a las tertulias de Domingo del Monte y colaboró con numerosas publicaciones, entre las que se cuentan Recreo de las Damas, Aguinaldo Habanero, La Cartera Cubana, Flores del Siglo, La Siempreviva, El Álbum, La Aurora, El Artista y Revista de La 
Habana (Márquez Sterling 77). Fue un patriota nacionalista, y junto al General Narciso López y otros, el progenitor de la bandera nacional cubana actual. Hay que apuntar que Narciso López, perseguía la anexión de Cuba a los Estados Unidos, y aunque no hay pruebas, es posible que Villaverde en su condición de secretario particular del General ambicionara similares propósitos.

Cecilia Valdés o La loma del Ángel es considerada como una de las más representativas de la cubanía tanto por sus temas como por su argumento; asimismo, se puede considerar la primera novela cubana y casi todos los críticos coinciden en situarla como "la más importante de nuestro siglo XIX" (Historia 1:395). Su argumento, típico de una época en que las discrepancias entre los nativos y los españoles se acrecientan, versa sobre los años de 1830. Novela en dos tomos, el primero fue publicado en 1839, pero el segundo no vio la luz hasta 40 años después, cuando se publica la obra completa. Esto ocurrió en Nueva York en 1879, ciudad en la que residió el autor casi permanentemente luego de su exilio forzoso desde 1849, cuando escapó de la cárcel por conspirar contra la corona. Y luego en su versión definitiva en 1882 en la cual, "aunque se mantiene algo de lo publicado anteriormente, hay un cambio sustancial tanto de forma como de contenido" (Perfil histórico de las letras cubanas 2:395).

La novela tiene el mérito de "pintar" la sociedad cubana, haciendo un corte transversal de todos los estratos sociales que la componían entonces, empezando por el Capitán General en la cúspide y terminando en la base que formaban los esclavos. El límite racial, que parece que divide a la sociedad en dos espacios claramente delimitados entre negros y blancos, se va haciendo más borroso a medida que avanza la narración, la cual comunica en estado embrionario el nacimiento de la sociedad cubana como 
típicamente mulata. Algunos críticos aprovechan la falta de un héroe protagonista y las múltiples digresiones marginales para destacar que "el método realista que Villaverde sigue lo lleva, desde cierto punto de vista, a no concentrarse en un personaje determinado..., y por eso el verdadero protagonista de la novela es colectivo: esa masa dividida y subdividida" (Énfasis añadido, Perfil histórico de las letras cubanas 2:398).

Cecilia Valdés ha sido adaptada en innumerables ocasiones a diferentes formatos culturales e ideológicos, en dependencia del momento histórico, por su conveniencia con el mestizaje y el tono novelado. Igualmente ha sido trasplantada al género musical escénico de la zarzuela, en una obra del mismo nombre compuesta por Gonzalo Roig y llevada a las tablas originalmente en 1932, con tal éxito que aún es considerada la obra cumbre del teatro lírico cubano. En 1982 fue adaptada al cine por el cineasta cubano Humberto Solás, quien, entre otros cambios, pone el peso de la obra en las tensiones históricas y políticas de la época en que transcurre la trama novelesca (entre 1812 y 1832 aproximadamente), con las conspiraciones abolicionistas de Aponte en 1812 y la intentona independentista de los Rayos y Soles de Bolívar de 1823. A pesar de las incomprensiones y los ataques a la versión del director de cine a raíz de la exhibición del filme en 1982, con los años ha venido a ser considerada un clásico del cine cubano.

En 2012, a treinta años del estreno, el crítico de cine Rafael Grillo menciona como la "reescritura" de Solás, con la incorporación de elementos freudianos "y el perfil edípico de la díada padre-hijo, con la madre como eje primordial del deseo"', se hizo con la intención de ahondar en las motivaciones de los comportamientos humanos y colocarlos más allá de la mecánica de las interrelaciones causa-efecto sugeridas desde el tejido social ("Cecilia"). Los protagonistas de la obra reaparecen en la novela La isla de 
los amores infinitos, de Daína Chaviano desenvolviéndose en papeles muy diferentes al original, y en las que el propio Cirilo Villaverde figura también como personaje $\mathrm{e}^{14}$. Por su parte, el escritor cubano Reinaldo Arenas hizo su propia versión de la novela, en su obra de corte satírico La Loma del Ángel. Se puede afirmar que Cecilia Valdés es representada cada vez a la luz de las cambiantes circunstancias históricas.

I. 5. Polémica en torno a la anexión y la esclavitud. Liberalismo, reformismo y autonomía

La idea de la inmortalidad es sublime porque prolonga la existencia del individuo más allá del sepulcro; y la nacionalidad es la inmortalidad de los pueblos y el origen más puro del patriotismo. José Antonio Saco (Obras 2:9)

José Antonio Saco López Cisneros (Bayamo 1797 - España 1879) fue un sociólogo, periodista, historiador y economista cubano, pionero en intentar un acercamiento al concepto de identidad nacional. Se opuso tanto a la subordinación española como a la corriente anexionista a favor de los Estados Unidos. Sus principales méritos se resumen en ser un promulgador de ideas progresistas y en el avance de la educación, así como en trabajar intensamente en busca del desarrollo e interacción entre la educación y la economía. La figura de Saco es una de las más controvertidas del siglo XIX cubano, y los estudiosos de su obra llegan a conclusiones distintas, y en muchos casos totalmente opuestas, sobre sus ideas. Para algunos, Saco fue un anti abolicionista, defensor de la esclavitud. Para otros, un portavoz del reformismo cubano, pues sus escritos aspiran a obtener por parte de España concesiones políticas pero sin llegar

\footnotetext{
${ }^{14}$ Daína Chaviano (Cuba 1960) reside en Miami desde 1991. Su obra La isla de los amores infinitos recibió la Medalla de Oro en el certamen Florida Book Awards 2006 al Mejor Libro en Lengua Española. La obra ha sido publicada en 25 idiomas y es la novela cubana más traducida de todos los tiempos.
} 
necesariamente a la concesión de la independencia. Otros estudiosos se interesan en el papel que el pensador cubano tuvo en la formación de la nacionalidad cubana (Opatrny, “José Antonio Saco" 81).

Saco es el letrado que por primera vez esboza el concepto de nacionalidad cubana, y aunque se niega a dar una definición explícita sobre el término: “[c]onfieso, que no es fácil definir claramente esta palabra: porque consistiendo la nacionalidad en un sentimiento, los sentimientos se sienten, pero nunca se esplican [sic] bien" (Obras 2:119), la expone con ejemplos y la contrapone y diferencia al concepto de nación, pues si “toda nación supone nacionalidad. . ., toda nacionalidad no constituye nación, por que [sic] hay muchas naciones que se componen de pueblos diferentes, teniendo cada uno de ellos una nacionalidad propia” (Obras 2:120). ${ }^{15}$ Dirigió Saco la Revista Bimembre Cubana desde 1832 hasta su clausura dos años más tarde, momento en que también fue desterrado. El resto de su producción intelectual la desarrollaría fuera de Cuba, a dónde solo volvería en una ocasión.

Otra arista de José Antonio Saco fue su oposición a la aceptación del negro como cubano. Para Saco, el cubano no podía ser negro. El discurso de Saco es en este sentido positivamente racista. El trabajo de los esclavos en las plantaciones_planteaba Sacopodía ser sustituido por los pequeños campesinos, inmigrantes de España peninsular o de las Islas Canarias. Además propugnaba que la faena debería llevarse a cabo por trabajadores industriales asalariados en ingenios modernos y mecanizados. Su principal reserva contra el anexionismo fue el peligro que podría sufrir la cubanidad de los

\footnotetext{
15 Para más información sobre este tema, véanse los ensayos de Saco "Ideas sobre la incorporación de Cuba en los Estados Unidos" de 1848 y "Réplica de Don José Antonio Saco a los anexionistas que han impugnado sus ideas sobre la incorporación de Cuba a los Estados Unidos" de 1850.
} 
habitantes de la isla. Saco puntualiza: "nunca olvidemos. . que la raza anglosajona difiere mucho de la nuestra por su origen, por su lengua, su religión, sus usos y costumbres; y que desde que se sienta con fuerza para balancear el número de los cubanos, aspirará a la dirección de los negocios en Cuba; y la conseguirá" (Obras 2:9). Y sus ideas conclusivas son que Cuba no solo fuese rica, ilustrada, moral y poderosa, sino que fuese Cuba cubana y no anglo-americana.

Gaspar Cisneros Betancourt—en contrapunto—estuvo a favor de aceptar la disolución de la nacionalidad cubana dentro de la sociedad anglosajona norteamericana mediante lo que consideraba un intercambio ventajoso: trocar cultura, lengua y religión cubanas por bienestar, desarrollo y democracia norteamericanas, incluyendo el blanqueamiento de la población a través de la mezcla con la raza anglosajona. En carta a su amigo Saco, escribió:

Independencia para descartarse de España y sus ladrones; anexión para tener un apoyo fuerte contra la Europa y contra nosotros mismos que al cabo, Saco mío, españoles somos y españoles seremos engendraditos y cargaditos por ellos, olindo de guachinangos, zambos, gauchos, negros, Paredes, Santa Ana, flores ¡Qué dolor Saco mío! ¡Qué semilla! ¡Oh Dios! ¡Por Dios hombre; no me digas que deseas para tu país esta nacionalidad! (cit. en Opatrny "La cubanidad" 99)

I. 6. Independencia y soberanía en José Martí

Por diferentes que hayan sido las aproximaciones políticas (a la figura de Martí) existe una especie de consenso. Empujar el mito (de Martí) en una misma dirección: aquella desde la que se le pueda sacar el mayor partido político independientemente de la perspectiva ideológica desde la que se le enfoque. 
¿Qué papel juega en este repertorio mítico la figura, recurrente, de José Martí? Por más de medio siglo, la muerte de Martí en 1895 frente a las tropas españolas fue entendida, por la mayoría de los cubanos, como un sacrificio apostólico que debía ser vengado por el regreso de un Mesías que, por fin, daría término a la "revolución inconclusa" y alcanzaría la libertad de Cuba. Una buena parte de ensayistas recientes han estudiado el deterioro cada vez mayor de esa invención en el ideario nacional. Entre ellos está Rafael Rojas, quien alude al arraigo de esos mitos en la simbología del orden totalitario. Para el crítico cubano residente en México, los bandos antagónicos que representan el castrismo y el anticastrismo tienen un aspecto en común: la sacralización de Martí. En una conversación sostenida con el periodista Ernesto Hernández Busto así lo certifica: "Castro cree haber cumplido esa promesa [la de dar término a la revolución inconclusa] y muchos de sus enemigos aspiran a 'reconquistar' el sepulcro martiano. Sin embargo, ese mito es una construcción de los lectores y ‘discípulos' de Martí” (43). Ya en el año 1953 lo había prometido. En el famoso alegato La historia me absolverá, transcripción de la defensa de Castro ante el tribunal que lo juzgaba por la acción armada, el entonces incipiente líder llega a asegurar que la memoria y las doctrinas de Martí son tan importantes que "hay jóvenes que en magnífico desagravio vinieron a morir junto a su tumba, a darle su sangre y su vida para que él siga viviendo en el alma de la patria. ¡Cuba, qué sería de ti si hubieras dejado morir a tu Apóstol!” (43). Si aun las naciones más liberales y democráticas siguen apuntalando sus identidades en apologías fundadoras, no es de extrañar que el propio Fidel Castro se apropiara del mito martiano para afirmar su programa revolucionario luego del ataque al Cuartel Moncada. 
${ }^{16}$ Mito que ha prevalecido casi incólume desde el triunfo revolucionario. Y esa práctica se retomó con mayor fuerza luego del descalabro del campo socialista, cuando la solidaridad de los proletarios del mundo se hizo añicos.

En 1994, el escritor y ensayista Abel Prieto ${ }^{17}$ vuelve a utilizar la figura de Martí para ilustrar cómo la Revolución vino a cerrar el círculo del ideario martiano:

Martí hizo un repaso de la historia y la cultura de la patria, y volvió sobre los hombres (guerreros, poetas, pensadores) que contribuyeron con su obra y su palabra a edificar la nacionalidad cubana. Tiene de su lado 10 años de historia con sobrados ejemplos de heroicidad y de virtud. Vuelve a la epopeya del 68 continuamente, a su papel en la unión y hermanamiento de amos y esclavos, negros y blancos, ricos y pobres; a su condición de singular escuela para la república futura; a la idea del sacrificio colectivo como purificación del ser nacional. . . . La Revolución. . . puso en primer plano el ideal inconcluso de Martí y de los fundadores. ("Cultura, cubanidad"2)

La importancia de Martí para la política y cultura cubanas continúa siendo fundamental, pero no necesariamente de incondicional fervor. Ensayistas recientes se han acercado a la figura y la obra del hombre y escritor que fue Martí soslayando su imagen

\footnotetext{
${ }^{16}$ El asalto al Cuartel Moncada, en Santiago de Cuba, fue parte de una acción armada llevada a cabo el 26 de julio de 1953 bajo el mando del entonces abogado Fidel Castro. El propósito era tomar el cuartel y llamar al levantamiento popular para derrocar al gobierno del presidente Fulgencio Batista. La acción fracasó y Fidel Castro resultó preso.

17 Abel Prieto (1950), escritor y político cubano, era a la sazón presidente de la Unión de Escritores y Artistas de Cuba (UNEAC). Ministro de Cultura por quince años (1997 - 2012), es actualmente asesor del presidente Raúl Castro.
} 
mítica. Por ejemplo, Antonio José Ponte llama la atención sobre la violencia del estilo de José Martí, “muchas de sus páginas tienen la vehemencia que tienen las imágenes en el cine mudo", estilo que además es tan "arrasador, sublime, grave, que puede a veces llamarse, peyorativamente patético" ("El abrigo de aire" 49). Ese estilo fue una de sus dos pasiones. La otra—continúa Ponte—fue "fundar Cuba". De ahí que "lo que escribió y su nación imaginada y su propia figura, presuponían la cita en los carteles. .., la obligación escolar de leerlo y el servicio a cuanta política cubana aparezca" (Énfasis añadido, 50).

Martí, el intelectual público por antonomasia de la historia de Cuba, el fundador de la ideología revolucionaria y sus estatutos, el que dice "Yo quiero que la ley primera de nuestra república sea / el culto de los cubanos a la dignidad plena del hombre", estrofa adoptada como ley a la Constitución cubana de 1976, es ese extraño político que también desea que lleguen "los días buenos, del trabajo después de la redención. . ., días de buena fe para evitar el exceso de política" y que admite, incluso, que "la política es una profesión enojosa de la que, a veces, se puede desertar" (cit. en R. Rojas, "El intelectual y la revolución" 81).

El canon revolucionario se propone a sí mismo como una representación fiel de las ideas martianas. Cualquier identidad entre su invención nacional y alguna de las construcciones estatales que registra la historia de Cuba, desde su muerte hasta hoy, se ha convertido en un rito más dentro de nuestra cultura. El temor actual del oficialismo cubano es evocar a Martí desde una óptica radicalmente diferente que pueda hacer tambalear los ya roídos cimientos de la credibilidad. El temor actual de la oposición es que el gobierno revolucionario, que ha esgrimido como bandera al apóstol desde 1953 
con el asalto al Moncada y-quiérase o no-lo exportan como el artífice de la misma, reinvente a Martí una vez más:

Como se sabe, el proyecto revolucionario cubano es, desde los días del asalto al cuartel Moncada, declaradamente martiano, y ahora, más que en otras décadas, sostiene en mucho su viabilidad en la idea martiana de la ética, la justicia social, la independencia nacional, el antiimperialismo y el humanismo. ... Lo nacional martiano, desde donde se afianza hoy la Revolución, funciona en la práctica política del Estado como continuidad ideológica totalitaria de los modelos clásicos de totalitarismo del socialismo real, ya inviables. (Morales, "La invención de Rojas” 3)

En el "Manifiesto de Montecristi” están las ideas esenciales del nacionalismo respaldado por Martí: la denuncia del sustento del orden colonial, la apelación a la voluntad nacional y el sentimiento antiimperialista. Un día antes de caer abatido escribe José Martí a su querido amigo Manuel Mercado:

Ya estoy todos los días en peligro de dar mi vida por mi país, y por mi deber — puesto que lo entiendo y tengo ánimos con que realizarlo—de impedir a tiempo con la independencia de Cuba que se extiendan por las Antillas los Estados Unidos y caigan, con esa fuerza más, sobre nuestras tierras de América. Cuanto hice hasta hoy, y haré, es para eso. En silencio ha tenido que ser, y como indirectamente, porque hay cosas que para lograrlas han de andar ocultas. (Obras completas 4:45)

Su visión política era liberal. Además, su obra política y de propaganda muestra estas tres prioridades: la unidad de todos los cubanos como nación en el proyecto cívico 
republicano de postguerra, el fin del dominio colonial español y evitar la expansión estadounidense.

Antonio José Ponte, para definir la ascensión a partir de los noventa del totalitarismo nacionalista cubano, escoge la figura de Cintio Vitier, apoderado y abanderado del Centro de Estudios Martianos, como su mejor adalid. Ponte expresa sobre el poeta y ensayista cubano: "Sobrevivir a Lezama le tendía patente. A sus setenta y un años. . Cintio Vitier mayoreaba la fiesta. ... [S]i el vacío material se había expresado en las escrituras de [Eliseo] Diego a través de un tono sombrío y penoso, para Vitier es todo lo contrario ya que el poeta aprende a sacar soberbia y energía de la escasez que lo rodea" (cit. en Álvarez-Borland 450).

En el tono "grave" más que en sus declaraciones explícitas, Vitier propone que lo comprometido y lo trascendente no es una opción entre otras propuestas por Martí, sino la única que le permitirá al cubano arribar a su destino prometido (Del Risco 58-9). Como un fiel sacerdote del martianismo, Vitier atribuye a Martí una cubanidad esencial, de la cual se considera el eje o la cifra. Es decir, velar por Martí es velar por la esencia nacional. Cierto que lo que Vitier intenta no es trazar explícitamente el perfil de una cubanía típica, sino que aspira a que seamos capaces de sentirlo o presentirlo, cobrando conciencia de su magia, de su azar y su deseo. Para Rojas "una cosa es vislumbrar Cuba como historia abierta, lectura, práctica, habla o escritura, a la manera de Fernando Ortiz; y otra, muy diferente, es asumirla como fundamento poético, sustancia, cifra, emblema, ideología, lenguaje, al estilo de Cintio Vitier" (Isla sin fin 97). La invención de Cuba en Martí crea — parafraseando a Rojas—el centro emisor de luz del canon en la literatura cubana. 
I. 7. Modernismo, nihilismo y cosmopolitismo. Casal y Varona

Casal vivió para el arte, que no por el arte; eso hay que respetarlo, eso es de raíz sagrada. Tiene que ver mucho con mi generación: no estaba el dólar e íbamos al ICAIC aunque no tuviéramos trabajo, íbamos a hablar de cine, nos metíamos ocho, diez horas hablando de cine; nueve décadas atrás Casal con sus amigos hablaba de poesía. Es extraordinario que en un país joven tuviéramos a alguien así, conozco naciones más antiguas que no los tuvieron.

Dean Luis Reyes

Casal. A comienzos de la última década del siglo XIX, y a contrapelo de los fueros independentistas y las luchas entre criollos y españoles, una renovación se produce en las letras cubanas, esta vez a través de la pluma innovadora de un joven poeta: Julián del Casal y de la Lastra (La Habana, 1863 - 1893), pionero y mejor exponente—junto con Rubén Darío-del modernismo en Latinoamérica. La calidad e importancia de su obra, la influencia de su ensayística y sobre todo de su poesía, así como su intensa vida, merecerían una revisión exhaustiva, la cual por razones de espacio es imposible de desarrollar en el presente trabajo. El estudio de su legado y de su propia figura hace más rica y compleja la definición de lo cubano que lo que hasta hace poco se había inculcado.

Una imagen como la que Casal proyecta no se aviene al prototipo del hombre viril sacrificado en aras de la patria y el bien común. Por el contrario, Casal es el prototipo del artista que se consagra a su arte pues "fuera del Arte, nada interesa en la vida" (Julián del Casal. Poesía completa 339) y bien valdría para él lo que escribió acerca del pintor Eduardo Menocal: "amando el arte por encima de todo, no solo por alcanzar la gloria; sino por los goces íntimos que proporciona a los elegidos; teniendo confianza en sus propias fuerzas, que se desarrollan cada día y le aseguran el triunfo definitivo" (Julián del Casal. Poesía completa 307). 
No es asimilable para la política oficialista, aun cuando se refiera a otra época, que las nuevas generaciones se enfrenten a textos que consideran "los tiempos modernos. .. abominables, no solo por sus ideales utilitarios, sino por los millones y millones de lugares comunes que, acerca del amor, de la política, de la religión y de otras cosas más, vomitan diariamente en nuestros oídos sus numerosos panegiristas". Para los propugnadores de la tríada patria-arte-virilidad, una figura tan desacorde con ese canon, un triste "artista solitario que. . . se guarece temprano en su desmantelada buhardilla, sin que el estruendo de la muchedumbre hormigueante le permita hojear en silencio sus libros favoritos, concluir el poema empezado o verter sus lágrimas amargas" ha resultado difícil de incorporar, y por lo mismo ha sido dejado en los márgenes. No obstante, cada día son más los seguidores y admiradores de este poeta (Julián del Casal. Poesía completa 306, 340).

No sería descabellada la revisión de toda una construcción de la identidad nacional que reconozca a Casal como su mejor representante o centro. Quizás esté cada vez más cerca el día en que se reconozca fehacientemente el valor de los "raros". La influencia de la obra de Casal es cada vez más pujante. De suerte con esto, el poeta y ensayista Jorge Luis Arcos señala que "toda la crítica marxista que demeritó a Casal queda derrotada frente al permanente influjo de sus versos, de su pathos, de su imagen" (Desde el Légamo 43), para luego aseverar que "Casal acaso..., es el poeta cubano más importante-por polémico-, de nuestra historia literaria (40).

Sea como precursor o iniciador, sea como miembro de pleno derecho, la producción literaria de Julián del Casal se ubica dentro del panorama literario que se conoce como modernismo. ¿Qué fue el modernismo? Según Oviedo, la multiplicidad de 
manifestaciones a veces dispares que se encierra dentro de la noción de modernismo le permite decir que "no hay un modernismo, hay una pluralidad de modernismos, de amplias vías abiertas dentro de un cauce común. Esta pluralidad no solo se da de autor a autor y de región en región, sino dentro de un mismo individuo. .., ya sea que lo observemos sincrónica o diacrónicamente. Es decir, todos los entrecruzamientos, superposiciones y contradicciones son posibles dentro del modernismo" (Historia de la literatura hispanoamericana 2, 218). Lo que marca más hondamente ese movimiento viene a ser-agrega Oviedo—el "haber establecido como principio esencial del arte la libertad para crear y alcanzar ese 'reino interior' del que hablaba Darío" (218).

En el corto período de tres años, antes que la muerte lo alcanzara inesperadamente antes de cumplir los 30 años, Casal publica los tres libros que constituyen sus obras completas: Hojas al Viento (1890), Nieve (1891) y Bustos y rimas en 1893. Ya antes, el poeta Juan Clemente Zenea, nacido en Bayamo en 1832 y fusilado en 1871 víctima de la política del XIX, y frustrado ante la realidad nacional, había marcado en 1861 una nueva línea en la poesía hispanoamericana. Su deseo de evasión es claro en estos versos de "En días de esclavitud":

Tengo el alma, ¡Señor!, adolorida por unas penas que no tienen nombres, y no me culpes, ¡No!, porque te pida otra patria, otro siglo y otros hombres. Que aquella edad con que soñé no asoma, con mi país de promisión no acierto, mis tiempos son los de la antigua Roma, 
y mis hermanos con la Grecia han muerto. (cit. en Lezama Lima, Antología 199)

Pero es ciertamente Julián del Casal quien con mayor maestría expresa esa sombría relación con la historia, elevándola al nivel de una ética de la indiferencia o del desdén. Es un ente que nada ansía, que se aparta de las aspiraciones típicas de los mortales. En su poema "Nihilismo" se nota la desventura y el desaliento de la existencia del bardo: "Amor, patria, familia, gloria, rango, / Sueños de calurosa fantasía, / Cual nelumbios abiertos entre el fango / Solo vivisteis en mi alma un día" (Julián del Casal. Poesía completa 187).

Tuvo que dedicar Casal muchas horas a la actividad periodística para subsistir. Y su pluma también fue mordaz y crítica contra la burocracia y la ineptitud de las instituciones. Una serie de crónicas titulada La sociedad de La Habana le costó el modesto empleo de escribiente en el Departamento de Haciendas debido a su sátira implacable. Nada menos que la dedicada al capitán general de la isla a la sazón, el general Sabas Marín: “Teniendo la desdicha de estar rodeados de malos consejeros, el general se ha hecho antipático a sus subordinados. Tanto la prensa, a quien persigue tenazmente, como el comercio, a quien no ha querido escuchar, lo han dejado en el más terrible aislamiento. Todos comentan desfavorablemente sus actos gubernamentales" (Julián del Casal. Poesía completa 281).

En Casal se plantea la contradicción entre la búsqueda de plenitud en una belleza imposible o inalcanzable y su circunstancia hostil. Su irradiación, aparte de la que tuvo en el modernismo finisecular, alcanza a los mejores poetas de todo el siglo XX cubano. Para 
apuntalar la importancia de Casal en la poesía de la isla, el también poeta y ensayista Jorge Luis Arcos pregunta:

¿Cómo entender el exotismo lírico de Regino Pedroso, el intimismo simbolista de Dulce María Loynaz, la sentimentalidad poética de Eugenio Florit, el acendrado y solitario purismo de Mariano Brull. . . o el neorromanticismo de Emilio Ballagas, e incluso la veta entre romántica y modernista de una zona de la poesía de Nicolás Guillén, sin un antecedente como Casal? (Las palabras son islas 4)

Vitier en su artículo "Casal como antítesis de Martî" apunta que Martí encarna en nosotros las nupcias del espíritu con la realidad, con la naturaleza y con la tierra misma, mientras Julián del Casal encarna todo lo contrario (cit. en Julián del Casal. Prosa 91). La invención de Cuba en Martí crea—parafraseando a Rojas—el centro emisor de luz del canon en la literatura cubana. Rojas demuestra cómo pueden colocarse en dos galerías contrapunteadas, las que conforman el canon y el contracanon: de un lado los que representan "lo autóctono", lo "sincero", "lo propio" y, del otro, los que reflejan "lo raro", "lo artificial”, “el nihilismo”. Martí y Julián del Casal encabezarían una y otra galería. La imagen histórica de la cultura nacional cubana se ha agotado y el oficialismo actual está necesitado de reinventarse, por lo que cediendo y abriendo espacios a aquellos escritores que desdeñan, obvian y enaltecen la contracorriente porque el antiguo concepto ha dejado de ser el correcto y las inquietudes se alzan frente al muro del imaginario impuesto.

Varona. El educador y ensayista Enrique José Varona (1849 - 1933) no se dejó atrapar por una postura filosófica encerrada o una corriente en particular. De ahí su 
importancia para este estudio, de su duda constante de la definición de nacionalidad que se pretendía imponer a la isla. Simpatizó la mayor parte de su vida con el positivismo sui generis que se manifestó en América Latina, pero también supo dejarlo a un lado y superarlo cuando comprendió sus limitaciones: “¿Y si tropezamos con el Ave Fénix, con el gobernante perfecto? Como el gobernante perfecto ha de ser un hombre, no demos ocasión a que el tiempo cercene y fatalmente ha de cercenarle sus perfecciones. Que sirva en su único período, de modelo y de estímulo" (cit. en Rodríguez Fernández 130).

Este luchador en el campo de batalla durante la Guerra de los Diez Años, ${ }^{18}$ al finalizar se une al movimiento autonómico y reinicia sus actividades literarias las que se vuelven más intensas, dicta y publica en La Habana sus célebres "Conferencias Filosóficas sobre Lógica, Psicología y Moral"; más tarde, ante el fracaso como diputado a las Cortes de España representando a Cuba, rompe con el autonomismo. En 1915 Varona vislumbra lo cubano como imposible, en la Academia de Artes y Letras: "El monstruo que pensamos haber domeñado resucita. La sierpe de la fábula vuelve a reunir fragmentos monstruosos que los tajos del héroe habían separado. Cuba republicana parece hermana gemela de Cuba colonial" (Varona, Textos escogidos 57).

En el 1921 pronuncia su discurso "El imperialismo yanqui en Cuba", colabora asimismo en la Revista Bimestre Cubana, y en 1923 preside a solicitud de Julio Antonio Mella, el acto de fundación de la Federación Estudiantil Universitaria (FEU). El pensamiento de Varona estuvo muy marcado por las influencias de su época, al principio

\footnotetext{
${ }^{18}$ La Guerra de los Diez Años o Guerra Grande, es como se conoce el período comprendido entre 1868 y 1878, declarada la primera guerra de independencia cubana contra la metrópoli española. Comenzó con el Grito de Yara el 10 de octubre de 1868, llevado a cabo por Carlos Manuel de Céspedes, y concluyó formalmente con el Pacto del Zanjón.
} 
fue la huella dejada por Félix Varela y José de la Luz y Caballero, los que influenciaron un pensamiento humanista, idealista, con una marcada postura positivista. Sin embargo, a medida que avanza el nuevo siglo y más precisamente al abandonar la vicepresidencia de la República en 1921, aparecen en él manifestaciones de nihilismo en las que se aprecia la impronta de Nietzsche. Algunos estudiosos de su obra lo han catalogado como un escéptico. Solo al final de su vida parece haber recobrado el optimismo en un momento en que las luchas estudiantiles contra la dictadura de Machado lo convierten en mentor y guía de las juventudes estudiantiles universitarias.

La enseñanza para él ocupaba un lugar primordial en la sociedad, principalmente cuando se cimentaba en recursos y valores modernos y científicos. Su concepción de la educación estaba por delante de su tiempo en Cuba. Apoyó la modernidad, la ciencia, la enseñanza y la democracia como pilares fundamentales del bienestar de una nación:

Que se haga descansar toda la obra de nuestra enseñanza sobre una base estrictamente científica para que sea objetiva, experimental y práctica, hacer que el adolescente adquiera sus conocimientos del mundo, del hombre y de la sociedad de un modo principalmente directo y no de la manera reflejada en los libros y las lecciones puramente verbales, es preparar a los hombres para la activa competencia a que obliga la multiplicidad de relaciones de la vida moderna no espíritus para la especulación fantástica. (cit. en Guadarrama González 33)

Compartió las tesis spencerianas de la defensa del individuo frente al Estado, pero las luchas políticas en Cuba lo llevaron a cambiar de opinión y a considerar que al menos en la situación cubana el Estado debía ser centralizado con energía por el poder ejecutivo. 
El Estado no era tanto la organización de la sociedad, sino la constitución del derecho y la justicia, especialmente la defensa de los derechos humanos. Sabía que los gobernantes inevitablemente se corrompían por el poder.

\section{8. Conclusiones parciales}

En el siglo XIX en Europa y América las literaturas independientes y soberanas se consolidan a partir de procesos democráticos. Pascale Casanova lo ilustra de la siguiente manera: "El lazo entre política y literatura se reafirmó de una forma explícita por medio de las teorías de Herder. Desde entonces el lazo de la literatura con la nación no era ya una simple etapa necesaria en la construcción de un espacio literario, sino que se reivindicaba como un logro" (142). La literatura que emerge en el transcurso del siglo XIX procura una expresión estética de voz propia, actuando a modo de fragmento de la construcción de una modernidad a partir de la lectura crítica y abierta del canon europeo $\mathrm{u}$ otras provenientes de diversos referentes culturales.

Los escritores cubanos establecieron su labor intelectual en el período colonial como parte de proyectos relacionados con el proyecto identitario de la isla y con el imaginario de nación que ellos contribuyeron a construir. Esto se manifiesta en la manera que ha prevalecido a la hora de la conformación del canon cubensis: "ha sido la percepción común cómo el texto"—asevera Enrico Mario Santí—“contribuye a forjar la identidad nacional" (134). Desde sus inicios, las letras cubanas han estado profundamente politizadas y consecuentemente han imaginado una nación utópica auxiliada por un arte nacionalista como patrón. En los dos últimos siglos el tratamiento del tema ha sido un discurso y una práctica cultural monopolizados por ciertas élites criollas, sobre todo 
blancas y mestizas, que se empeña en identificar históricamente lo cubano y lo revolucionario, en detrimento de lo cultural. Como advierte el poeta y ensayista Francisco Morán "el canon oficial literario cubensis es un canon ante todo político, y por lo mismo construido a expensas de lo literario" (24-25).

Hay ciertos textos literarios que en virtud de su productividad ideológica son sometidos a tachaduras y ajustes para sostener determinados programas narrativos críticos. Esto ayuda a entender la pertenencia (o no) de textos y autores a la condición de “canónicos", que ha estado ligada a la existencia de una agenda previa condicionada políticamente por aquellos que controlan el aparato cultural. En nuestros días, el prejuicio a que se encuentran sometidas las obras literarias está dado principalmente por la censura impuesta a toda manifestación considerada "no oficialista". No obstante, es necesario reconocer que han existido iniciativas que no acatan la cuasi obligada cosmovisión nacionalista, y evitan o se apartan de la problemática de la nación como tema. A pesar de la preponderancia del nacionalismo afirmativo, ha existido asimismo en el pensamiento de la isla otra variante de nacionalismo, generalmente menospreciada y ninguneada por los que controlan la difusión de la cultura y las ideas. Este discurso alternativo, en oposición al afirmativo (que en la etapa revolucionaria se solapará e identificará con el discurso "oficial"), tiene como principal rasgo su visión irónica y desconfiada de los grandes relatos que forman la nación. Son precisamente los representantes de la escuela alternativa quienes han adquirido en la actualidad la mayoría de los espacios literarios.

La importancia de Martí para la política y cultura cubanas continúa siendo fundamental, pero no necesariamente de incondicional adhesión. Ensayistas recientes se han acercado a la figura y la obra del hombre y escritor que fue Martí soslayando su 
imagen mítica. Para esos investigadores la obra y vida de Martí se comienzan a alejar de la esquina patriótica para acercarse a la esquina humana de Casal, quien reivindica su estatura al frente de la poética nacional. No sería descabellada la revisión de toda una construcción de la identidad nacional que reconozca a Casal como su mejor representante o centro. La influencia de la obra de Casal es cada vez más pujante, cada vez está más cerca el día de la incorporación plena de los "raros", encabezados por Casal, en la cultura nacional. 


\section{CAPÍTULO II}

\section{LA NARRATIVA CUBANA DE LO NACIONAL A LO POSNACIONAL. SEGUNDA}

\section{ETAPA.}

Pregunta: Más que ocasionalmente usted hizo periodismo, ¿Por qué se desligó de él; no son compatibles el periodismo y la poesía?

Respuesta: Por los años 45 colaboraba con la prensa. Hice periodismo por espacio de catorce años, dejé de escribir cuando a Cuba llegó la Revolución. Dulce María Loynaz (Entrevista con Yamilé Ferrán)

España es derrotada y se instaura la República de Cuba en 1902. Los intelectuales del siglo XX manifiestan las ansias de ser los representantes de la identidad cubana. ¿Quiénes somos y adónde vamos? La literatura, las artes y la filosofía resurgían luego de la euforia y el optimismo, con énfasis en la literatura y las artes escénicas, teatro crítico y realista, representando la tragedia política de una isla ocupada por los Estados Unidos en 1898 y desde 1906 hasta 1959 plena de gobiernos corruptos, cuyos momentos de máxima tensión serían los períodos de las dictaduras de Gerardo Machado (1925-1933) y el segundo mandato de Fulgencio Batista (1952-1958). En las primeras dos décadas de la República se pasó de la exaltación acrítica de la Revolución, que había dado origen a la independencia, al progresivo despliegue de lo que se ha llamado el discurso del desencanto republicano. Como se verá en las novelas que comienzan a publicarse en la segunda década republicana y continuarán durante toda la década siguiente (con Miguel de Carrión, José Antonio Ramos y Carlos Loveira entre los casos más notables), la crítica se centraba sobre la idea de la revolución, o para ser más precisos sobre la idea de revolución puramente política y sobre el tipo de líderes que habían emergido de éstas (Del Risco 192-3). 
En la llamada Revolución del 30 convivió la antigua definición de revolución como insurrección armada contra los poderes establecidos con la de proceso radical de transformaciones políticas, sociales y económicas (Del Risco 196). Por su parte, para la llamada Generación del 23 o Minorista, la Revolución además de política, social y económica, tendrá una dimensión cultural, estética y creativa (Del Risco 199). Glosando a Rafael Rojas y situando también a Anderson, se puede asegurar que a partir de 1959, en el momento en que los revolucionarios toman el poder y logran controlar el Estado, el modelo de nacionalismo oficial alcanza su oportunidad al encontrarse por primera vez con la posibilidad de usar el poder para realizar sus anhelos. La pertinencia es mayor en la medida en que incluso los revolucionarios más decisivamente radicales heredan, hasta cierto punto, el Estado del régimen derrocado, y mientras algunos de estos legados son meramente simbólicos, no por ello son menos importantes (Anderson 224).

Luego de tres décadas y el subsecuente agotamiento ideológico y fracaso práctico de la doctrina comunista en la Unión Soviética y la Europa del este, se produce la aceptación implícita pero aún negada a nivel oficial, del debilitamiento de las doctrinas marxistas-leninistas y de su transmisión a través de los aparatos ideológicos del Estado. El miedo estatal se compensa con una inflamación de la retórica nacionalista (R. Rojas, Cultura e ideología 84).

Durante la década de los ochenta, el pensamiento posmoderno internacional (Foucault, Derrida, Lyotard, Habermas, Bell, Rorty, Vattimo) había cuestionado los discursos identitarios y establecido el reconocimiento de la diferencia como condición de una racionalidad plural y comunicativa. En los noventa, la crítica del enunciado de la identidad cultural se intensificó con el multiculturalismo, un nuevo paradigma que 
propugna las alteridades sexuales, genéricas, religiosas y artísticas e impulsa discursos y prácticas posnacionales. En sociedades poscoloniales como las latinoamericanas, las políticas culturales de fines del siglo XX, alentadas por intelectuales como Néstor García Canclini y Roger Bartra, abandonaron el patrón del nacionalismo subalterno y asumieron la representación de una subjetividad que se diferenciaba más allá o más acá de los grandes relatos identitarios (R. Rojas, Cultura e ideología 88).

En el campo literario los relatos contemporáneos para ser universales, paradójicamente abandonan los ideales que pretendían la universalidad. Es decir, se evita la obra total y se busca la vida cotidiana, las simples emociones y la individualidad, universales en el sentido de idénticas para cualquiera en cualquier lugar del mundo. Se busca lo común, lo anodino. De acuerdo con Chatellus las prosas de hoy "abandonan las ideologías, las normas los -ismos de todo tipo. Desaparecen la política, las utopías y la religión. Las escuelas literarias tampoco existen, y los textos incluso abandonan los ideales sociales" (160).

En Cuba, por el contrario, el gobierno busca apuntalar su autonomía tras la caída del Muro de Berlín, refugiándose en la "defensa de la identidad de la cultura cubana", construida a partir de una politización revolucionaria de la cultura con la llegada de una Revolución antiimperialista al poder. La identidad nacional no puede prescindir de un paradigma político único. La creación de un panteón literario nacional y la historia de los grandes escritores (concebidos como "bienes nacionales"), símbolos de un "fulgor" y de un poder intelectual, se vuelven necesarias para la afirmación de la potencia nacional (Casanova 144). Como expone Casanova, el carácter nacional de la literatura se fijó a través de una serie de rasgos proclamados específicos: la francesa como sucesión de 
siglos, la inglesa a los reinados, la española por generaciones. ¿La cubana? Pascale Casanova en La república de las letras puede ayudarnos un poco a intentar descifrarlos:

Las luchas unificadoras del espacio internacional se libran principalmente en forma de rivalidades dentro de los ámbitos nacionales. Oponen, dentro de un mismo espacio literario nacional, a los escritores nacionales (los que se remiten a la definición nacional o popular de la literatura) con los escritores internacionales (los que recurren al modelo autónomo de la literatura) $\mathrm{Al}$ mismo tiempo, se puede comprender que estas bifurcaciones que estructuran el espacio mundial son las mismas que las que oponen a los formalistas y los académicos, a los antiguos y los modernos, a los regionalistas y los cosmopolitas, a los provinciales o periféricos y los centrales. (150)

II. 1. El telos insular en Lezama y Piñera. El discurso grave de Vitier

¿Qué diría de Fidel Castro una hipotética Enciclopedia Británica a fines del siglo XXI?

Oscuro dictador que vivió en una isla del Caribe en tiempos de Lezama Lima. Gastón Baquero (cit. en Hernández Busto “Gastón Baquero”).

La vanguardia de la Revista de Avance, ${ }^{19}$ la estética insular de Orígenes, cuyos integrantes (católicos en su mayoría) mantenían una posición tradicionalista y elitista respecto al tema de lo cubano, así como la rebeldía existencial de Ciclón manifestada— según palabras de Jean Marie Lemogodeuc —en su carácter "sistemáticamente rebelde y

\footnotetext{
${ }^{19}$ La Revista de Avance (1927-1930) fue una publicación quincenal (y luego mensual) cubana. Entre sus editores figuraron Alejo Carpentier, Jorge Mañach y Juan Marinello. Considerada el principal órgano de la vanguardia literaria cubana en la época, la revista publicó poemas y ensayos literarios, así como se dedicó a la divulgación de artículos sobre música y artes plásticas.
} 
contestatario. . . contra la sociedad burguesa, sobre todo en el terreno de las costumbres y la sexualidad" (cit. en Lobato Morchón 78), fueron silenciadas por el oficialismo revolucionario posterior al triunfo de la Revolución.¿Cuáles fueron los motivos para arremeter y proponer como bandera una literatura ligada, desde la temática hasta los lexemas, a la unidad revolucionaria, girando — como expresó Fowler—alrededor de un "núcleo fundacional” llamado José Martí? Quizás la respuesta pase inexorablemente porque en ellas — como rosas y espinas—están las manos del esencialista Lezama y la posición descreída y antagónica de Piñera, bifurcando en un imaginario nacional intelectual muy diferente a los postulados oficialistas.

La poética propugnada por los origenistas, ${ }^{20}$ en cuyo núcleo se situaban Lezama, Vitier, García Marruz, Eliseo Diego y García Vega, tenía un fuerte componente religioso. Sus integrantes "comparten una profunda repugnancia hacia la conversión de la literatura y la poesía —asevera Duanel Díaz-en actividades autónomas, independizadas, como el propio hombre moderno, de la gracia y la caridad", posición acompañada por "una cierta reticencia ante otras cosas que se caracterizan. . . por su tendencia a dejar de ser medios para convertirse en fines: el sexo, el dinero, el intelecto, los bienes materiales". Es decir, hay una preocupación ante la pérdida de la inocencia del acto poético, al caos de la vida moderna, a través de una "interpretación católica de la modernidad liberal e industrial como una catástrofe que ha dado al traste con un orden cimentado por la fe, la caridad y la piedad" (Los limites del origenismo 20, 26).

${ }^{20}$ Origenista es llamado todo aquel fundador y colaborador de la revista Orígenes. 
Piñera. La aparición de Ciclón (1955 -1959), que lideraba Virgilio Piñera (antiguo miembro de Orígenes), sería una respuesta a la moralidad y religiosidad de los líderes de Orígenes y representó a su vez una lectura negadora del imaginario de la nación cubana que los origenistas erigieron desde su estética. Con estos propósitos, desde sus páginas, Ciclón acercaba una fresca mirada nacional desde perspectivas contestatarias. También se aproxima a este criterio Ricardo Lobato Morchón, quien además añade que la revista no solo se ciñó al rechazo a la política republicana, y no solo debe entenderse como una denuncia coyuntural restringida a la sociedad cubana del momento (80).

Jorge Mañach, el gran intelectual republicano, evocaba en alguna ocasión, quejoso, lo que llamó "la nación que nos falta". La manera en que Virgilio expresa esa falta de nación es a través de una visión negativa de la insularidad, a través del descrédito. Cuba como país sin apenas historia, sin pasado. Es en su poema "La isla en peso", publicado originalmente en 1943, donde mejor se puede apreciar lo anterior. La condición de estar rodeado por mar convierte la existencia en un agobio: "la maldita circunstancia de estar rodeado de agua por todas partes / me obliga a sentarme en la mesa del café. / Si no pensara que el agua me rodea como un cáncer / hubiera podido dormir a pierna suelta" (6). Cuba se refleja en su poema como un pueblo infantil, joven, y la confianza de Piñera hacia la capacidad creadora de sus compatriotas es escasa: “¡Pueblo mío, tan joven, no sabes ordenar”! ¡Pueblo mío, divinamente retórico, no sabes relatar!” (32).

También menciona Piñera ese sol brutal del mediodía que embota los sentidos y no permite pensar. La circunstancia insular impide entender lo que pasa afuera. Interesa 
destacar también la irreverencia del poema en tanto texto que propugna un concepto alternativo de entender la cubanía: es escéptico, secular y vulgar, en oposición a los conceptos de sus contemporáneos origenistas (entre ellos Lezama Lima y Cintio Vitier), profundamente esencialistas, católicos y conservadores. No solo rechaza el entendimiento de la cubanidad en los términos místicos de estos, asimismo se resiste a dar un esclarecimiento del concepto: “País mío, tan joven, no sabes definir!” (10). Este poema, considera Reinaldo Arenas "es la base de toda la obra piñeriana; él nutre y fundamenta lo mejor de su creación. . . Él mismo es el drama de la intemperie y la persecución, la desesperación, el vacío y la asfixia de todo un pueblo" ("La isla en peso" 39). Se entiende mejor ahora, como asevera Mark Weiss con fino humor, que "Piñera seems to have been most comfortable at the margins, and he would have been resistant to inclusion in any circumscribed cubanidad. I imagine him, if asked, echoing Groucho Marx: 'I would not join any club that would have someone like me for a member"” (3).

A Vitier, una de las voces críticas más autorizadas dentro del discurso canónico de la cultura cubana, la angustia existencial y el sentimiento de frustración que atraviesa el poema no le parecen características propias de lo cubano. Nada de pesimismo demoledor y de desidia es admitido. En su libro Lo cubano en la poesía de 1958, años después de la publicación de "La isla en peso" expulsa del canon de la literatura cubana al irreverente texto de Piñera: "Es obvio en el tono y en la tesis de este poema el influjo de visiones que. . . de ningún modo y en ningún sentido pueden correspondernos. Nuestra sangre, nuestra tradición, nuestra historia. . . nos impulsan por caminos muy distintos" (Énfasis añadido, cit. por Juan Padrón 4). Pero no por mucho tiempo los caminos serán muy distintos. Justamente son los nuevos autores los que imitan y reverencian "la lengua 
de Virgilio" en el estilo y sobre todo en el espíritu. La recuperación de la obra de Piñera que se ha producido a partir de los noventa ha desatado el "fenómeno Piñera". Las características más salientes de esta generación—recuerda Damaris Calderón—, "el uso de la parodia, la ironía, la revisión de la épica, la aparición de un discurso gay, la desmitificación del arcadismo social, geográfico, poético, tienen una fuerte impronta piñeriana ("Virgilio Piñera: una poética" 5). Pero también recogen de Piñera su nihilismo y la resistencia a los discursos totalizantes y utópicos que son parte de su obra.

Si en "La isla en peso" Piñera niega el imaginario de lo cubano formulado por la estética origenista, en el teatro, la postura de Piñera contraria a la teleología insular lezamiana se había puesto a prueba antes, en 1941, en su pieza teatral Electra Garrigó. En "Piñera teatral", prólogo del dramaturgo a su Teatro Completo, el autor induce al lector y/o espectador, tanto como al crítico, a descifrar las claves estratégicas no solo de Electra Garrigó, sino de todo su teatro. Del Risco sostiene que los valores indiscutibles de esta pieza y de su autor se deben a que Piñera trasciende como el más consistente productor de un discurso de choque. Por su parte Rafael Rojas ve en Piñera al heredero de Casal, en la medida que acoge el patriotismo débil que antes encarnaba el poeta decimonónico, tanto por su "levedad histórica de Cuba" como por la herejía y la transgresión del texto (Isla sin fin 119).

El protagonista de las obras de Piñera, a veces trasunto del propio autor, es por lo general el hombre desarraigado, desposeído y sin dioses, "héroe (o antihéroe) contemporáneo [que] al asumir la tragicidad, el resplandor, la verdad insular-antillana, y muy especificamente cubana — como certeramente apunta Reinaldo Arenas-, se contempla bañado (o anegado) por una claridad que lo refleja y obsede, [y] está 
conde[nado] a perecer si se rebela y a desaparecer si acepta" ("La isla en peso con todas sus cucarachas" 31 ). Es decir, los antihéroes de Piñera no tienen salida o escapatoria posibles y están destinados al fracaso de antemano.

Un abrumador minicuento de Piñera, que merece ser citado en su totalidad, sirve como un buen ejemplo del desasosiego existencial que afecta al hombre más allá de los cerrados marcos nacionales:

El hombre se acuesta temprano. No puede conciliar el sueño. Da vueltas, como es lógico, en la cama. Se enreda entre las sábanas. Enciende un cigarrillo. Lee un poco. Vuelve a apagar la luz. Pero no puede dormir. A las tres de la madrugada se levanta. Despierta al amigo de al lado y le confía que no puede dormir. Le pide consejo. El amigo le aconseja que haga un pequeño paseo a fin de cansarse un poco. Que enseguida tome una taza de tila y que apague la luz. Hace todo esto pero no logra dormir. Se vuelve a levantar. Esta vez acude al médico. Como siempre sucede, el médico habla mucho pero el hombre no se duerme. A las seis de la mañana carga un revólver y se levanta la tapa de los sesos. El hombre está muerto pero no ha podido quedarse dormido. El insomnio es una cosa muy persistente. ("En el insomnio" 53)

Virgilio Piñera publica en 1967 su novela Presiones y diamantes, una sátira aparentemente situada en una ciudad cualquiera, que sin mucho esfuerzo puede ser ubicada precisamente en La Habana de esos años, pues "el lenguaje es coloquial y directo, los nombres de las personas, incluyendo sus apodos, son típicos del país, los 
modismos y expresiones no pueden ser más cubanos" (Arenas, "La isla en peso" 35). Si a eso se le suma que la trama gira alrededor de la búsqueda de un diamante llamado el Delphi (anagrama de Fidel), que resulta al final ser una piedra falsa sin ningún valor, lanzado finalmente al inodoro, se puede colegir que cuando la "travesura" fue descubierta por las autoridades cubanas "los ejemplares de Presiones y diamantes, retirados de todas las librerías, sufrieron más o menos la misma suerte que el apócrifo Delphi”( Arenas, "La isla en peso" 36), y su autor no pasó de ser un anónimo traductor hasta su muerte en 1979.

Antonio José Ponte resume la obra de Piñera cuando expresa: "Nos legó un repertorio de frases que decir en las guaguas o las paradas por donde no pasan, en las casas de huéspedes y el bar, la esquina y el patio de butacas, la antesala del dentista y la funeraria, el parque y la carnicería, la barbería y la cola del pan, la crónica social y policíaca, el secreteo y el grito del solar. Como personajes suyos hablamos en Piñera clásico, hemos caído en la lengua de Virgilio" ("La lengua de Virgilio" 59). Lo antes mencionado puede explicar el repunte acelerado del aprecio y del estudio entre los jóvenes creadores cubanos de la obra piñeriana.

Lezama. Para muchos especialistas, el conjunto de la obra lezamiana representa dentro de la literatura hispanoamericana una ruptura radical con el realismo y la psicología y aporta una alquimia expresiva que no provenía de nadie. Julio Cortázar fue uno de los primeros en advertir y celebrar la singularidad de dicha propuesta. La obra de José Lezama Lima sigue trascendiendo más allá del tiempo y las fronteras. Muchos poetas y narradores posteriores, cubanos, latinoamericanos y españoles, admiten la influencia significativa que la propuesta de Lezama ha tenido en ellos: el caso más 
notorio sea quizás el de Severo Sarduy, que postuló su teoría del neobarroco a partir del barroco de Lezama.

Roberto Méndez Martínez considera que "la obsesión principal del escritor [se refiere a Lezama Lima] fue esa teleología que es la penetración de la poesía en la historia para conformar un destino" (“Paradiso, cuarenta años" 10). En la obra de este importante escritor hay una voluntad de búsqueda en la cultura cubana del "mito que nos falta". La insularidad, que para Piñera funcionaba como una maldición y un agobio, en Lezama es un reto y acicate para que la isla cree su propio mito que no puede ser medido con los raseros de otras latitudes. En su afán totalizador de esencias, el poeta se empeña en diseñar un sistema poético, que es a la vez una filosofía y un programa estético (Méndez Martínez 7).

Es a través de Paradiso como Lezama mejor desarrolla su sistema poético, alzándose de paso con una de las obras maestras de la narrativa del siglo XX cubano, latinoamericano y universal. En ella confluye toda su trayectoria poética de carácter barroco, simbólico e iniciático. Aventura poética y narrativa que se resiste a definiciones, cuando fue publicada a principios de 1966 por primera vez en las librerías cubanas, fue recibida con escepticismo y asombro: "se habló de hermetismo y pornografía, se le llegó a negar no solo la condición de novela sino hasta la más general de texto literario" (Méndez Martínez 5). Lezama corrió una suerte similar a la de Piñera, y a principios de los 70 y hasta su muerte acaecida en 1976 fue apartado del sistema, mientras toda su producción narrativa fue censurada. No es hasta principios de los noventa, cuando se empieza la recuperación de su obra. 
La complejidad de la producción lezamiana y el carácter críptico de su obra ha confundido y fascinado a buena parte de la crítica y del público. El crítico Emir Rodríguez Monegal ha llamado a Lezama el único barroco de verdad en Cuba "con toda la carga de significación que lleva esta palabra, es decir, tradición de cultura, tradición hispánica, manuelina, berniniana, gongorina" (cit. en Sarduy Escrito 71). De ahí se entiende que una novela como Paradiso "podría leerse como una desplegada Soledad cubana. .., todo el aparato discursivo de la novela, tan complejo, no es más que una parábola cuyo centro — elíptico — es el ‘culteranismo’ español” (Sarduy Escrito 71). A lo anterior Rogelio Rodríguez Coronel agrega la conveniencia de acercarse a la obra lezamiana con una visión integradora "que trascienda los límites de la anécdota, de las modulaciones del sistema de personajes, de la linealidad casualista, de la formulación de mensajes más o menos explícitos. Lo narrativo, pues, se revela en la extensión de la imagen portadora de una solicitud gnóstica que sobrepasa la inmediatez referencial" ("La obra narrativa de José" 201).

De acuerdo con Severo Sarduy, Lezama plasma el fundamento mismo de la isla como una constitución de diferentes culturas. Es decir, lo cubano se da como superposición y no como síntesis de culturas:

Cuba no es una síntesis, una cultura sincrética, sino una superposición. Una novela cubana debe hacer explícitos todos los estratos, mostrar todos los planos "arqueológicos" de la superposición. . y y lograr lo cubano con el encuentro de estos, con su coexistencia en el volumen del libro, o, como hace Lezama con sus acumulaciones, en la unidad estructural de cada metáfora, de cada línea. (Escrito sobre un cuerpo 69) 
En "Introducción a los vasos órficos", el poeta acude al mito de Orfeo y Eurídice para ilustrar sus ideas sobre la esencia de la lírica. Observa Víctor Fowler que en este ensayo "Lezama trabaja con el mito que narra el descenso de Orfeo a los infiernos y hace que el fracaso del amante. . quede transformado en una gigantesca victoria para la poesía" (cit. en Álvarez-Borland 445). En efecto, la trágica historia de Orfeo exhibe los elementos que constituyen la creación de lo poético: la evocación de la pérdida (el canto de Orfeo), la imposibilidad de su recuperación (la triste suerte de Eurídice) y la búsqueda del objeto deseado mediante la imagen (la creación de la poesía). Para Lezama, el deseo o querencia de lo imposible se nutría de la plenitud semántica de la imagen. En sus diversos ensayos sobre la lírica, Lezama describe la poesía como escenario del deseo o el lugar donde el objeto querido estaba siempre ausente. Según él, la salvación del poeta estaba en su capacidad para recrear imágenes y su horror en la falta de ellas (Álvarez Borland 445).

En resumen, Lezama estructuró un sistema poético del mundo pues quiso explicar el conocimiento del mismo desde la otra orilla, desde lo desconocido, y en ese recorrido lograr el desvelamiento de un nuevo ser nacido de la oscuridad: la poesía, creando un sistema para explicar el mundo a través de la metáfora y de la imagen.

II. 2. La tríada Nacionalismo, Revolución y Cubanía (1959-1971). Interludio marxistaleninista (1971-1992)

"Se acabó la diversión, llegó el comandante y mandó a parar" Carlos Puebla

Con la caída de Batista y la toma del poder por el nuevo gobierno, el vocablo Revolución pasó a designar no solo al proceso de transformaciones políticas y sociales 
que se produjeron a partir de 1959 y en los años sucesivos, sino a un persistente conjunto de términos como Patria, Nación, Estado, y hasta Comandante en Jefe, que llegaron a incorporarse en el imaginario popular y eventualmente a utilizarse indistintamente como sinónimos. El populismo de los primeros años evolucionó pronto hacia posicionamientos cada vez más radicales. Los artífices de la Revolución se han apropiado del adjetivo "revolucionario" para referirse a cualquier actividad generada dentro del marco institucional del castrismo. Se crea así un deporte revolucionario, un cine revolucionario, una manera revolucionaria de hacer las cosas, una ética revolucionaria, una actitud revolucionaria, etc. Dentro de ese revolucionarismo institucionalizado desde el poder, se incluye también la literatura. Como dice Del Risco, a partir de 1959 “el término revolución dejó de ser una referencia histórica y política para adquirir una dimensión metapolítica y metahistórica a la hora de darle sentido al relato de la nación” (18).

La Revolución triunfante, de carácter abiertamente popular y nacionalista, que había contado en los inicios con el apoyo y la euforia de la mayoría de los sectores sociales, comenzó una serie de reformas, en los inicios de manera tenue y luego bien radicales, avalada por el inmenso apoyo al proyecto revolucionario. Cuando la correlación de fuerzas se puso a favor mayoritariamente del nuevo régimen, las palabras traidor, contrarrevolucionario y gusano hicieron su aparición para calificar a todo o a todos aquellos que no se plegaran a la política oficial. La típica cultura crítica y de polémica abierta que se practicaba en la República fue acallándose hasta prácticamente desparecer.

Consecuente con esta política de gobierno, también la política cultural fue derivando hacia posiciones de extrema izquierda, azuzadas además por un marcado 
sentimiento antiimperialista. Cuba entraba en una nueva época de su joven y turbulenta historia, trayendo - como asevera Del Risco— "cambios en el vocabulario político" (178). La Revolución cubana, definida por Rafael Rojas de acuerdo a su mitología más profunda, en poco tiempo pasó a ser “no únicamente sus 'logros sociales', el gobierno revolucionario o la figura de Fidel Castro [sino] ante todo la unidad del caudillo y del pueblo, de Fidel y la nación en una guerra permanente contra un enemigo externo, el imperialismo yanqui, y sus posibles aliados en la isla" (cit. en Del Risco 212).

De ahí que la Revolución se convirtiera no solo en el resultado necesario e inevitable de toda la historia nacional, sino en su destino último, en la forma última de la nación. Este discurso constituyó desde entonces la referencia más autorizada a la hora de reconstruir este relato desde posiciones oficiales. La Revolución de proceso se constituyó en norma, en sistema (Del Risco 230). La modificación de la conciencia popular acarreó la transformación en todas las manifestaciones de las artes, incluida la literatura.

No obstante, hay que advertir que luego de la toma del poder, el régimen de Fidel Castro intenta desligarse, mientras se aseguraba las riendas del poder, de la clasificación de régimen comunista. El 21 de octubre de 1959, en un discurso en la provincia de Camagüey, afirma:

Siempre lo mismo, siempre lo mismo. ... ¿Acusarnos de comunistas para qué? Acusarnos de comunistas para ganarse el halago y para ganarse el apoyo de la reacción, para ganarse el apoyo de cancillerías extranjeras; presentarse acusando a los compañeros más valiosos de esta Revolución de comunistas.... Quien se dedique a la innoble y ruin tarea de acusar de comunistas a los compañeros revolucionarios, lo que está haciendo es 
hacerle el juego a Trujillo, a la reacción nacional, a los grandes intereses internacionales, a los criminales de guerra. ("Discurso" 21 de octubre de 1959)

Con la visita en febrero de 1960 del viceprimer ministro soviético Anastás Mikoyán y la concesión de un crédito de cien millones de dólares, además de firmar tratados para la compra de azúcar y la venta de petróleo, comienza la escalada soviética en la isla. En la etapa de 1960 a 1961, la Revolución se articula para resolver históricamente su propia ruptura. En una entrevista realizada al historiador y ensayista cubano Rafael Rojas con motivo de la aparición de su libro Tumbas sin sosiego (2006), este plantea en relación a la destrucción del orden republicano luego del triunfo revolucionario:

La Revolución que. . . en 1959 llevó a Fidel Castro al poder era profundamente republicana, ya que junto a una reforma agraria moderada demandaba el restablecimiento de aquella Constitución de 1940, anulada por Batista. El "renacimiento nacional" o reconquista de la soberanía frente a Estados Unidos no era una demanda importante desde la abolición de la Enmienda Platt en 1934, cuando Cuba dejó de ser, realmente, una entidad neocolonial. De modo que aquel "renacimiento" o "segunda independencia" fue, más bien, una construcción simbólica de las nuevas élites revolucionarias, en 1961, cuando ya estaban decididas a aliarse con Moscú, a insertar a la isla en el bloque comunista de la Guerra Fría y a fomentar, por tanto, el estatus de confrontación con Washington, que tanto 
les ha ayudado a mantenerse en el poder durante medio siglo. (cit. en Hernández Busto 43)

Ejemplos de este fervor nacionalista oficialista se manifiestan en las canciones de Carlos Puebla ${ }^{21}$ como "La Reforma Agraria", "Duro con él", "Ya ganamos la pelea" y "Son de la alfabetización", que sirven de embajadores de los "logros" revolucionarios. En la canción "De Cuba traigo un cantar" se muestra bien claro este papel asignado:

De Cuba traigo un cantar hecho de palma y de sol cantar de la vida nueva y del trabajo creador para el ensueño mejor cantar para la esperanza para la luz y el amor. (Puebla 3)

Ya en el propio 1959, con la creación del Instituto Cubano del Arte y la Industria Cinematográficas (ICAIC) y la Imprenta Nacional de Cuba, y luego en 1961 mediante la creación de la Unión de Escritores y Artistas de Cuba (UNEAC), comienza la intervención activa del Estado en la cultura. En la euforia de los primeros años de la revolución, esta participación estuvo relativamente abierta a la polémica y lo moderno, permitiendo la "inscripción de la isla en las vanguardias de la cultura occidental" (R. Rojas El estante 10).

${ }^{21}$ Carlos Puebla (1917-1989) fue un cantante popular, conocido como el cantor de la revolución por sus loas a las actividades revolucionarias y a sus dirigentes. 
En su discurso de clausura de una serie de reuniones celebradas en julio de 1961 con la intelectualidad, y en el que se debatía si la política cultural iba a ser regida por la censura, y si debía permitirse o no una absoluta libertad de contenido en la expresión artística (alocución conocida luego como Palabras a los intelectuales), Fidel Castro, aunque no precisa una impronta para la escritura del momento, la resume bajo el principio rector, que luego devendría en postura paradigmática: "Dentro de la revolución: todo; contra la revolución, nada". La interpretación y puesta en práctica de "dentro" y "contra" se llevó de una manera arbitraria y voluntariosa. Aquella máxima sirvió como patrón de un discurso contradictorio e inestable, cuya lógica estableció la cuasi obligación de poner a la Revolución en el centro de la vida nacional, tanto en el ámbito social como personal (Del Risco 230). En un principio, este acontecimiento no inhabilitó forzosamente la independencia innovadora de los escritores, pues todavía se aceptaba la idea del intelectual como conciencia crítica de la sociedad y con cierta autonomía de criterios. No obstante, las referencias de los creadores debían tener cada vez más como centro la ideología revolucionaria.

La cultura "guevarista" 22 fue el comienzo del extremismo revolucionario. El Che Guevara afirmaba que "la culpabilidad de muchos de nuestros intelectuales y artistas reside en su pecado original; no son auténticamente revolucionarios" y proponía "injertar el olmo para que diera peras" y hasta recomendaba, en descubierta eugenesia comunista, "impedir" que aquella generación "pervirtiera a las nuevas" (cit. en R. Rojas, "El intelectual" 87).

\footnotetext{
${ }^{22}$ Denominada así por las ideas propugnadas por Che Guevara y vertidas principalmente en su folleto $E l$ socialismo y el hombre en Cuba.
} 
Con la creación en 1967 del Instituto Cubano del Libro ${ }^{23}$ se endurece el control ideológico riguroso por parte del Estado de la política cultural. Se pasa entonces a la idea del intelectual comprometido políticamente con el régimen. También por entonces se encona la polémica sobre el papel social del intelectual, elemento que se torna bien visible durante la entrega de los premios literarios de la UNEAC en 1968 (el famoso “caso Padilla”). Al intelectual para entonces se le exhorta a ser por antonomasia "revolucionario", y como tal—plantea Lisandro Otero—, la cristalización de la conciencia de su papel debe ser "como contribuyente a la obra común y no como conciencia crítica frente a ella” (cit. en Rodríguez Coronel 21). Es lo que Rafael Rojas califica como "intelectual orgánico”, y cuya tragedia es ofrecer su imaginación y su obra al Estado para, a cambio, obtener una precaria libertad: la libertad de sobrevivir (El arte $160)$.

Otros tipos de corrientes y tendencias narrativas van quedando relegadas a partir de la férrea censura constituida por estas fechas en que se persiguen las inmoralidades y “conductas impropias”. Como parte de lo que se llamó la Ofensiva Revolucionaria se institucionaliza el giro dogmático ${ }^{24}$. Escuchar rock, tener el pelo largo, vestir de cierta manera, conductas sociales y sexuales determinadas se convierten en causas suficientes

\footnotetext{
${ }^{23}$ Heredero de la Imprenta Nacional de Cuba creada en marzo de 1959, el Instituto Cubano del Libro se funda en abril de 1967.

${ }^{24}$ Anunciado en marzo de 1968 en uno de los habituales discursos de Fidel Castro, la Ofensiva Revolucionaria fue el término con que se conoció el proceso de confiscación masiva de pequeños establecimientos y negocios. Se calcula que en ese año de 1968 se confiscaron más de 55500 negocios de esas características. Además de las confiscaciones de la propiedad se aplicó la nacionalización de los derechos de autor y de la propiedad intelectual, con lo cual se eliminó solicitar la autorización para divulgar una obra que se consideraba de interés para el país, así como el pago a los creadores por su obra. Véanse "La ofensiva revolucionaria de 1968, 44 años después" de Oscar Espinosa Chepe y "Diccionario del castrismo cotidiano".
} 
para ser enviado a campos de reeducación. Los homosexuales, entre otras víctimas por excelencia de esta política, fueron perseguidos y enviados a "reeducarse" a las Unidades Militares de Apoyo a la Producción (UMAP). ${ }^{25}$

En 1971, en el discurso de clausura del primer congreso de Educación y Cultura, justamente una década después de sus famosas Palabras a los intelectuales, la extensión relativa de libertad expresiva de artistas y escritores de que se había gozado en el país se cierra con una férrea mordaza. En este evento Fidel Castro sentencia:

¿Concursitos aquí para venir a hacer el papel de jueces? ¡No! ¡Para hacer el papel de jueces hay que ser aquí revolucionarios de verdad, intelectuales de verdad, combatientes de verdad! Y para volver a recibir un premio, en concurso nacional o internacional, tiene que ser revolucionario de verdad, escritor de verdad, poeta de verdad, revolucionario de verdad. Eso está claro. Y más claro que el agua. Y las revistas y concursos, no aptos para farsantes. Y tendrán cabida los escritores revolucionarios, esos que desde París ellos desprecian, porque los miran como unos aprendices, como unos pobrecitos y unos infelices que no tienen fama internacional. ... Tendrán cabida ahora aquí, y sin contemplación de ninguna clase, ni vacilaciones, ni medias tintas, ni paños calientes, tendrán cabida únicamente los revolucionarios. (Énfasis añadido, "Discurso 30 de abril de 1971")

\footnotetext{
${ }^{25}$ Las UMAP fueron campos de trabajo forzado que se establecieron en Cuba y estuvieron en funcionamiento entre 1965 y 1968. Se calcula que más de 30.000 jóvenes fueron obligados a trabajar en estos, en labores agrícolas por más de 60 horas semanales. Los más perjudicados por esta política fueron los homosexuales, los testigos de Jehová y los grupos marginales. Veáse el interesante ensayo sobre este tópico de Joseph Tahbaz "Demystifying las UMAP: The Politics of Sugar, Gender, and Religion in 1960's Cuba".
} 
A partir de 1971 y durante las dos décadas siguientes, a la condición mencionada de abrir espacios únicamente para los escritores revolucionarios de verdad, se va a sumar el compromiso de aplicar el canon estético del realismo socialista, configurado de acuerdo con la filosofía marxista-leninista en que va a inscribirse el país, etapa en la cual "se arriba a una mayor madurez ideológica y estética en lo que concierne a la recreación de la realidad socialista" (Rodríguez Coronel 23). Los grandes temas, los únicos avalados y permitidos, son los que giran alrededor del presente y el porvenir de la realidad socialista, su idealización y propaganda triunfal. El mensaje ideológico predomina sobre el artístico.

Apunta Roberto Fernández Retamar que no es “extraño que el rasgo básico de la literatura de nuestra Revolución sea la perspectiva socialista a partir de la cual se producen sus obras", para luego aclarar que la literatura revolucionaria no se constriñe a las obras en que explícitamente aparece la Revolución como tema pues "más allá del tema, más en lo hondo, está la perspectiva, la visión: no es lo que se mira, sino cómo se mira lo que define tal carácter revolucionario” (Énfasis añadido, cit. en Rodríguez Coronel, La novela 17). Las premisas de las regulaciones para la literatura se inscriben dentro de una labor mayor: la de una sociedad en revolución "en un siglo cuya marca principal viene dada por las transformaciones hacia una etapa superior en el desarrollo de la humanidad, hacia el socialismo. . preámbulo del futuro en todo el Continente” (Énfasis añadido, Rodríguez Coronel, La novela 7). Las narrativas deberían tener en consecuencia el punto de mira socialista de la Revolución, estar en sintonía con ella. A grandes rasgos, podemos decir que entre 1971 y 1992, la política cultural se vio limitada 
por la férrea adscripción de la ideología oficial al marxismo-leninismo (R. Rojas $E l$ estante vacio 10).

Es pertinente poner un ejemplo de la manera en que el Estado, en este caso a través de un funcionario de la cultura, se inviste como fuente de legitimación para otorgar cubanía y de paso empacharse de manías de grandeza. El discurso de Abel Prieto ${ }^{26}$ en 1994, cuando fungía como presidente de la UNEAC es ilustrativo de esto: "La Revolución ha sido la obra más trascendente de la cubanía. Logró cambiar para siempre el destino del país, e intervino, sí, y decididamente, en el equilibrio del mundo" ("Cultura, cubanidad"). Como se ve en esta declaración, hay un secuestro absoluto de todos los símbolos patrios, las figuras más representativas de la nación cubana y hasta del concepto de nación. A esa declaración contundente y sin reservas le cabe bien la siguiente explicación de Benedict Anderson:

El modelo del nacionalismo oficial adquiere su pertinencia sobre todo en el momento en que los revolucionarios toman el control del Estado, y se encuentran por primera vez en posibilidad de usar el poder de éste para realizar sus sueños. La pertinencia es mayor en la medida en que incluso los revolucionarios más decisivamente radicales heredan, hasta cierto punto, el Estado del régimen derrocado. Algunos de estos legados son simbólicos, pero no por ello son menos importantes. (224)

\footnotetext{
26 "Cultura, cubanidad, cubanía" es el nombre con que se conoce la ponencia dictada por Abel Prieto, a la sazón presidente de la Unión de Escritores y Artistas de Cuba, en la primera conferencia La nación y la emigración, celebrada en La Habana los días 22, 23 y 24 de abril de 1994. Asistieron "invitados", es decir previamente autorizados por el gobierno cubano, algo más de 200 cubanos residentes en el exterior. En 1995 se celebró la segunda de dichas conferencias y luego en 2004 una tercera.
} 
Hasta aquí se pueden identificar, de manera simplificada para cumplir con los objetivos de esta investigación, dos grandes percepciones muy marcadas (sobre todo en el período 1959-1990) en la historia de la narrativa literaria en la isla: la oficial y la alternativa. Tomando el término prestado a Ambrosio Fornet, se podría decir más bien dos maneras de narrar la nación. En la oficial, la fusión de los conceptos nación, revolución y cubanía se amalgaman, y su misión es la búsqueda de la identidad y de la "esencia" de lo cubano.

Entre los principios que sustentan este designio encontramos el Mito de la Revolución Traicionada o Inconclusa, elaborado por Julián B. Sorel. Según su tesis, los promotores de este mito afirman que con el triunfo revolucionario de 1959 se lleva a feliz término lo que hasta entonces había sido un conjunto de traiciones a un continuum ideal revolucionario que se remonta a las guerras del siglo XIX. En el imaginario político de la Revolución, el fracaso del empeño separatista se debió "no tanto a las características del movimiento (impopular, clasista, regional) como a la actuación de fuerzas externas que perturbaron su natural desarrollo y feliz conclusión" (cit. en Del Risco 176). El 1 de enero de 1959, en el discurso que inaugura la epopeya revolucionaria, Fidel Castro contribuye a la consolidación del mito y reelaborándolo hasta alcanzar la versión definitiva en su discurso del 10 de octubre de 1968.

Empieza en 1959:

La República no fue libre en el 95 y el sueño de los mambises se frustró a última hora. La Revolución no se realizó en el 33 y fue frustrada por los enemigos de ella. Esta vez la Revolución tiene al pueblo entero, tiene a todos los revolucionarios, tiene a los militares honorables. ¡Es tan grande 
y tan incontenible su fuerza, que esta vez el triunfo está asegurado!

(“Discurso 1 de enero de 1959”)

Y remata en 1968:

¿Qué significa para nuestro pueblo el 10 de Octubre de 1868? ¿Qué significa para los revolucionarios de nuestra patria esta gloriosa fecha? Significa sencillamente el comienzo de cien años de lucha, el comienzo de la revolución en Cuba, porque en Cuba solo ha habido una revolución: la que comenzó Carlos Manuel de Céspedes el 10 de Octubre de 1868 y que nuestro pueblo lleva adelante en estos instantes. (“Discurso 10 de octubre de $\left.1968^{\prime \prime}\right)$

A partir de entonces, la teleología revolucionaria establece que la Nación cubana se identifica, indisolublemente, con un Estado, fundando así un orden totalitario (R. Rojas, Isla sin fin 87). Este enfoque instituye igualmente la noción de que patria y cubanía son patrimonio exclusivo de los revolucionarios. Otros rasgos son el antiimperialismo, la militancia izquierdista, el lenguaje teórico marxista y la violencia como vehículo de cambio. Del Risco menciona además que características propias de este discurso son el tono mesiánico, una comprensión teleológica de la historia y una vocación autoritaria (5). Los mejores representantes de esta línea de pensamiento repasados en este trabajo son: Félix Varela, José de la Luz y Caballero, José Antonio Saco, José Martí, Cintio Vitier y Fidel Castro.

Sin embargo en la cara alternativa, cubano y revolucionario no son sinónimos. Esta posición no reclama ni define la "esencia" de lo cubano, pues se compone de discursos múltiples y heterogéneos que interactúan en un juego de posibilidades. La 
aptitud de este discurso es anárquica, su tono es leve y su visión de lo histórico es irónica (Del Risco 5). El afán del mismo es universal, mundano, y como consecuencia la nación aparece fragmentada y atomizada. Sus defensores enfatizan rasgos que se apartan de la interpretación oficial, y son indiferentes, niegan o rechazan, entre otros, la violencia política como vehículo de cambio social, la equivalencia entre revolución y cubanía, la retórica de izquierda marxista y la ideologización de la narrativa.

\section{3. Poscomunismo cubano. Mitos y realidades (1992 -Actualidad)}

Asediados por el hambre, los apagones, la devaluación de los salarios y la paralización del transporte-entre otros muchos males-, Ana y yo vivimos un período de éxtasis. Nuestras respectivas delgadeces, potenciadas por los largos desplazamientos

que hacíamos en las bicicletas chinas que nos habían vendido en nuestros centros de trabajo, nos convirtieron en seres casi etéreos, una nueva especie de mutantes, capaces, no obstante, de dedicar nuestras últimas energías a hacer el amor, a conversar por horas y a leer como condenados-Ana poesía; yo, después de mucho tiempo sin hacerlo, otra vez novelas.

Leonardo Padura (El hombre que amaba a los perros)

Con la pérdida del mapa de los referentes identitarios, la literatura latinoamericana ha ido borrando las fronteras nacionales, lo que supone la ruptura de un modelo de escritor y una recomposición de su papel en la sociedad (Fernando Aínsa 57). Las difuminadas rivalidades oponen, dentro del mismo espacio literario nacional, a los escritores nacionales y los escritores que recurren al modelo autónomo. Para los nuevos literatos cubanos, no hacer mención de la patria, lejos de alejar la nación, enriquecería en su grandeza literaria. El canon debe reconocer y establecer la diferencia como condición de una racionalidad plural y comunicativa.

Sin embargo, se observa en el fenómeno cubano una asimilación de la esencia imperialista en el sentido de que todo lo odiado se asimila para luego, como dice Edward 
W. Said, "repetir sus mismos errores ante las individualidades discrepantes con la oficialidad o las nuevas minorías que, con la independencia, se forman en su territorio" (cit. en Castany Prado 179). Luego el crítico y profesor advierte de "los peligros de la conciencia nacionalista", en el sentido de que a menos que el nacionalismo se convierta en conciencia social, no pasará de ser más que una extensión del imperialismo, y cita a Franz Fanon cuando plantea que "la violencia del régimen colonial y la contra violencia del nativo se equilibran y se responden mutuamente con una homogeneidad extraordinariamente recíproca" (cit. en Edward Said, Cultura e imperialismo, 414).

La imagen histórica de la cultura nacional, consumida en guerras políticas fratricidas, y el amalgamiento de lo cubano y lo revolucionario, y manipulada hasta el agotamiento, ha permitido expresar a Rafael Rojas lo siguiente: "Desde finales de los años 80 se viene escribiendo un nuevo ensayo de la nacionalidad. .., [pues ya] los valores, los símbolos, las ideas, las prácticas y las instituciones del nacionalismo revolucionario experimentan un agotamiento fatal” (R. Rojas, Isla sin fin 217). En la constante búsqueda de una "jerga franca" donde poder abrir al mundo una puerta a los enigmas, los escritores hurgan desde el siglo XIX en su realidad personal. Pretenden osadamente deshacerse de doctrinas, y desertan en sus escritos de la gran realidad que supone Cuba y ser cubano, en un diálogo íntimo y ameno, o abierto y problemático, pero siempre individual, con las circunstancias en que les toca vivir. El contexto cubano impone nuevos retos a los escritores del siglo XXI, en una sociedad que desde la caída del Muro de Berlín se debate en una crisis sin fin.

En Cuba la Revolución y sus sempiternas doctrinas (a casi 55 años de un mismo gobierno en el poder), camufladas y reorientadas, se mantienen. El arte, a pesar de 
eventuales tropezones entre el gobierno y UNEAC, así como la aparición reciente de nuevos espacios culturales para los "no convencionales", sigue encontrándose con los mismos escollos. Es decir, apertura sin apertura. Si por una parte se puede disfrutar de Pánfilo ${ }^{27}$ haciendo críticas en el canal 41 de Miami, y cada semana hay un espectáculo de artistas cubanos que viajan a los Estados Unidos, en la isla no se permite la presentación en vivo de Willy Chirino en los escenarios, ni tampoco la difusión de la música de los artistas de la diáspora en ningún formato. Y así pasa con prácticamente todos los artistas que hayan realizado alguna crítica al régimen.

Como comenta Rojas, “en las últimas [décadas], el exilio interior ha sido un mecanismo de reproducción de la cultura más socorrido y eficaz que el éxodo" (Isla sin fin 187). Hablar de Marx o Lenin en Cuba ahora es como advertir que Buster Keaton existió o la película La guerra de las galaxias ganó el Oscar por efectos especiales, es decir cosas del pasado. Camilo y el "Che" son pinturas hippies en pulóveres y paredes. El debilitamiento del sustrato doctrinal marxista-leninista, y de su transmisión a través de los aparatos ideológicos del Estado, ocurrido luego de la caída del campo socialista, se ha visto compensado por una inflamación de la retórica nacionalista. Raúl Castro, en fecha tan reciente como el 1ro de enero de 2014, insiste en que el triunfo de la Revolución "es el triunfo del mismo ideal de los mambises que en 1868, con Céspedes a la cabeza, iniciaron la guerra por la independencia del yugo español; de Maceo y Gómez, con quienes José Martí en 1895 retoma la gesta libertaria”, para luego agregar que “[e]s también la causa que enarbolaron contra la república burguesa y neocolonial Baliño,

\footnotetext{
${ }^{27}$ Pánfilo es el nombre del protagonista de un programa humorístico de la televisión cubana:"Vivir del cuento" interpretado por el comediante Luis Silva.
} 
Mella, Rubén Martínez Villena, Guiteras y Jesús Menéndez, por solo mencionar a algunos" ("Discurso 1 de enero de 2014"). Es decir, lo mismo de siempre.

Se ha magnificado hasta límites inconcebibles a partir del agotamiento gubernamental—siguiendo a Anderson—la comunidad socialista perfecta del siglo XXI: imaginada, irreal y subjetiva, cargando a rastras la pesada carga, casi insoportable, de una sociedad inherentemente limitada y soberana. Aplicando los principios desglosados por Anderson a la realidad cubana se observa: Primero, en Cuba, a pesar de la existencia evidente de una desigualdad cada vez más pronunciada, la nación se concibe con un compañerismo profundo, horizontal e indivisible que trata de adaptarse y salir ilesa de la crisis mundial. Segundo, es imaginada porque los cubanos no conocerán jamás a la mayoría de sus compatriotas, no los verán ni oirán siquiera hablar de ellos, pero en la mente de cada uno vive la imagen de su representatividad comunitaria, la misma que supuestamente se ve obligada a lidiar con los problemas diarios. Y por último, se imagina soberana porque el concepto nació en una época en que la Revolución destruyó la tiranía.

En 2001, el ensayista e historiador de las ideas Rafael Rojas, concedió una entrevista al periodista Joaquín Ordoqui en la cual precisa que el comunismo cubano no carece de raíces nacionales. Una de esas raíces, a su juicio, es el nacionalismo extremo, es decir: "un conjunto de discursos y prácticas que, a partir de una imagen exaltada de los designios nacionales, moviliza intransigencias, autoritarismos y exclusiones" (1). Sin embargo, inmediatamente advierte que en la cultura cubana también hay testimonios de otros nacionalismos más suaves, que conforman un archivo de reservas cívicas: “ese archivo tendrá —recalca Rojas—... un valor inestimable en las próximas décadas" (cit. en Ordoqui 1). Son precisamente estos nacionalismos más suaves—o leves, como los 
nombra Del Risco- los que se entrecruzan con las coordenadas en las que se sitúa la literatura posnacional. Rafael Rojas con su importante libro Isla sin fin contribuye a desmitificar la cultura cubana y sus leyendas y reinterpreta la historia nacional desde una óptica novedosa, bajo el influjo de lo más sagaz del pensamiento contemporáneo. Su análisis es una arqueología de la construcción discursiva de la nación cubana.

\section{4. Conclusiones parciales}

¿Quién puede reír sobre esta roca fúnebre de los sacrificios de gallos? Los dulces ñáñigos bajan sus puñales acompasadamente. Como una guanábana un corazón puede ser traspasado sin cometer crimen.

Virgilio Piñera. ("La isla en peso" 16)

El refrito canónico oficialista manipula el orden de las prioridades literarias en aras de perpetuar el poder. Sin embargo, gradualmente Lezama Lima, Virgilio Piñera y otros escritores olvidados, obviados o desplazados porque se consideraban no productivos ideológicamente para el proyecto Estado-Nación, no tan solo resucitan, sino que pasan a ocupar altares donde el dominio de los artífices nacionales parecía intocable. Igualmente se está produciendo un fenómeno consistente en "humanizar" a escritores canónicos, desmitificándolos. Como se deduce de nuestro análisis, tan profunda ha sido la radicalización política del arte que la respuesta posnacional, íntima o nihilista está siendo igual de poderosa.

En el artículo "Convivio antillano", que glosa el libro Un banquete canónico de Rafael Rojas, la periodista Julieta Campos se pregunta con el autor: “¿Por qué, a diferencia de las otras literaturas latinoamericanas, la de Cuba sigue tan atada a lo que él 
llama el 'relato cultural de la nación?", y concluye Campos en que "la respuesta está donde él la encuentra: en que no han cesado las condiciones que inducen a seguir formulando un discurso de restitución histórica en torno a la identidad nacional" (Énfasis añadido, 97). En otra parte del mismo libro—siempre siguiendo a Campos—Rojas apunta cómo el intelectual cubano de la época republicana Jorge Mañach registra que la formación de la conciencia cubana, iniciada a principios del siglo XIX con auspicios prometedores, se había detenido con el advenimiento de la República, y ya por los años treinta y cuarenta del XX, la esencia caudillista de la 'ficción republicana', junto con la desilusión que siguió a la frágil independencia y la carencia de sustancia por debajo de la costra jurídico-formal trajeron como consecuencia lo que Mañach acuñó como 'conato de Estado en una patria sin nación"” (Campos 97). En todo caso, la conciencia de ser isla y de ser débiles asedió a los cubanos en los siglos XIX y la primera mitad del XX. Entre la fantasía de haberse adueñado del destino y la angustia de sentirse despojados de un destino han vivido los cubanos (dentro y fuera de la isla) la segunda mitad del siglo XX.

Por su parte, Roberto Fernández Retamar plantea que el cubano, en busca de su expresión, persigue la consolidación de la colectividad en detrimento de la individualidad. Retamar admite sin ambages que no hay espacio para la individualidad creadora, sino para la creación colectiva y asevera: “mi poesía no se ‘inserta' en la poesía cubana: en un momento dado, “es’ la poesía cubana” (Fernández Retamar 40).

De manera equivalente, existe una corriente de novísimos autores que incrementan su protagonismo entre los ya consagrados. Mediante la práctica de una literatura transgresora, violenta y con una marcada tendencia a presentar la sexualidad de forma explícita (a veces mediante un lenguaje sucio y profano), estos nuevos escritores 
rediseñan la estructura y los conceptos que sobre la sociedad y sus patrones existieron por más de un siglo. Paradójicamente, luego de tanta persecución contra lo ambivalente y lo marginal, el oficialismo, como veremos en el próximo capítulo, da cobertura al nuevo género, que inunda las librerías con literatura posnacional. Es la última manifestación de lo que Dorta Sánchez denomina acertadamente el canon cubensis de turno.

Sobre la cultura nacional, con arreglo al modelo que se ha intentado describir y retornando a las ideas de Rojas, el siglo XX podría resumirse en las etapas siguientes:

- 1902-1952: Retórica de la renovación cívica, las vanguardias artísticas y la espiritualidad nacional. Constitución de 1940.

- 1952-1959: Cultura republicana suspendida por la dictadura de Batista.

- 1959-1961: Revolución que se auto declama para resolver históricamente su propia ruptura.

- 1962-1990: Revolución guevarista en los 60; soviética a partir de $\operatorname{los} 70$.

- 1990-2000: Cultura crítica de la transición cubana actual. (R. Rojas, Isla sin fin 167-8)

En el próximo capítulo se tratará el tránsito hacia nuevas formas alternativas y su inserción en el contexto latinoamericano actual: posnacionalismo y homoerotismo. 


\section{CAPÍTULO III}

\section{LA TRANSICIÓN A NUEVAS FORMAS ALTERNATIVAS Y SU INSERCIÓN EN EL CONTEXTO LATINOAMERICANO ACTUAL. POSNACIONALISMO}

Yo he sido una persona con suerte y a lo mejor es por eso. Bueno, también porque nunca le he pisado la cabeza a nadie, ni me he metido en lo que no me importa. He hecho lo que me ha dado la gana, y a lo hecho pecho. Miguel Barnet ("Fátima o el parque de la fraternidad")

Sí, el sexo siempre ha estado presente en la literatura cubana y en la cultura en general, en los bailes, en todas sus manifestaciones. Pero creo que de una manera tan insistente lo he visto sobre todo en estos narradores de los noventa. Es algo constante, en ellos la problemática sexual es muy fuerte y muy abierta. (Margarita Mateo, cit. en Henríquez Lagarde)

En la obra de Calvino Marcovaldo o sea las estaciones de la ciudad, el peregrinar de Marcovaldo, protagonista de las veinte historietas situadas en lo que podría ser cualquier ciudad industrial moderna, "espíritu sencillo. . ., última encarnación de una serie de cándidos héroes pobrediablos a lo Charlot. . ., un Buen Salvaje exiliado en la ciudad industrial", puede ser aprovechado como alegoría del nuevo modo de hacer literatura en Cuba. En el prefacio, el autor esboza el desfase que se da entre la vida y las fantasías con que el protagonista nutre su anodina pero alegre existencia: "en medio de la ciudad de cemento y asfalto, Marcovaldo va en busca de la naturaleza. Pero ¿Existe todavía la naturaleza?" (Calvino 1). Esta especie de fábula del hombre moderno, sitúa la literatura contemporánea a la entrada de una naciente forma de colocar el ojo literario: la de la nostalgia, el nihilismo y el desencanto. Los (anti)héroes de hoy son seres inadaptados y desconectados que sobreviven en un mundo extraño. 
Resultaría asombroso, y en ciertos círculos nos podrían catalogar de sacrílegos, apostar por Zequeira como rimador ambiguo, a Martí bardo nihilista, a Heredia cantor erótico e incluso a Casal juglar nacionalista. Se pretende en este capítulo desligar las lecturas nacionales oficialistas que algunos de nuestros prosistas han llevado escritas rutinariamente en la contraportada de sus libros, hacia otras más inclusivas y abiertas. La ambigüedad, los temas, las atmósferas y las innovaciones formales de algunos de esos textos permiten que los mismos entren en un terreno resbaladizo y extraño, propicio para nuevas y enriquecedoras lecturas. Se busca a continuación promover una lectura productivamente ideológica de Zequeira que se aparte de las interpretaciones convencionales que han predominado en las últimas décadas.

III. 1. La aproximación alternativa a los orígenes del canon: Zequeira. Heredia. Martí y Casal

Zequeira. El precursor más notable de lo que devendría el discurso alternativo al que nos hemos referido antes es el poeta, corresponsal y militar Manuel de Zequeira y Arango. ¿Por qué? ¿Qué hay en este poeta militar que lo hace curiosamente equívoco? Nos interesa precisamente porque los "gérmenes" de significar "lo cubano" que parten de su obra han dado frutos de signos contrapuestos, de acuerdo con la interpretación y apropiación que de ella se ha hecho. Este letrado constituye el embrión de un asimétrico tronco literario en que se va a definir lo cubano a través de dos discursos críticos divergentes. Tronco bifurcado: por un lado, la rama fuerte y "viril” de la tradición afirmativa, y por el otro, la flexible y dúctil rama de la tradición alternativa. 
Además de lo ya mencionado en el capítulo anterior sobre la oda "A la piña", cuando tuvimos ocasión de comentar el aprovechamiento ideológico que se ha venido haciendo de esta composición para colocarla en el origen de un discurso poético nacional de "reafirmación"—-según Enrique Sainz-—de lo propio" y de "una devoción criolla que habla por sí misma del sentido de lo autóctono" (cit. en Dorta Sánchez 4), ahora se prefiere insistir en lo que "tiene del aquelarre y del grotesco" la obra de Zequeira, donde sobresale lo fantasmagórico, lo tenebroso y lo oscuro (Lezama, "Prólogo", 345), así como en lo que en ella hay de erótico.

Para Jorge Luis Arcos "fue Zequeira, antes que Heredia, el primer poeta nacido en Cuba que tuvo una sutil y profunda conciencia de su destino de poeta ('Nadie nos oye, sufro, soy poeta', dice en 'El barquero')”. Arcos se refiere a la condición de Zequeira, aun habiendo nacido en Cuba, como "español de ultramar", todavía moviéndose dentro del ámbito ideológico de la monarquía española: “¿se sentía Zequeira cubano?—pregunta el crítico-. Aunque escriba la frase 'patria mía', se sentía habanero, tal vez. Pero también español" ("Notas sobre Cuba y España"). Es decir, Zequeira queda un poco entre dos aguas, es una figura escindida en la que se debaten lo que Fina García Marruz considera "lo visible español y lo oculto americano" (37).

En la crítica a la obra de Zequeira llevada a cabo por los defensores del canon oficial (v.g. Vitier, Sainz, García Marruz y Mirta Aguirre), es notable la omisión por parte de estos de otra obra mayor del bardo: "La ronda", poema sin embargo rescatado y puesto en primera plana para ingresar en el canon por literatos y ensayistas de la talla de Lezama Lima y Jorge Luis Arcos. Lezama llega incluso a afirmar que esta composición de Zequeira "es para mí uno de los más verídicos momentos que puede ofrecer nuestra 
poesía", para luego agregar: "si se hiciese una selección de nuestros mejores veinte poemas, "La ronda" tendría que ser incluido entre ellos" ("Prólogo a una antología" 345). Con este poema -advierte Dorta Sánchez - "se observará en el discurso crítico de Lezama, en comparación con el de Vitier, una recolocación de los valores atribuidos a la poesía de Zequeira", para inmediatamente añadir que Lezama "es quien se dirige a aquella zona de la poesía de Zequeira olvidada y hasta denostada por la crítica del XVIII y del XIX, para refundar una axiología" (Énfasis añadido, 5). A continuación unos fragmentos de estos enigmáticos versos rescatados:

Yo aquel súbdito obediente

Que en grado superlativo,

Soy militar a lo vivo

Y esqueleto a lo viviente.

Con un silencio profundo

Como si nadie viviera,

Seguimos nuestra carrera

Como almas del otro mundo

No obstante, como concibe

Que todos íbamos muertos,

Con trémulos desaciertos

Gritando nos dá $[$ sic $]$ el quien vive $(251,252,253)$. (Severino Boloña Colección de poesías arreglada por un aficionado a las musas) 
Incursión preñada de alusiones afiebradas, grotescas, fantasmagóricas, ambiguas. El protagonista, una suerte de fantasma en atuendo militar, circula por los puestos de vigilancia que rodean la ciudad amurallada de la época. Durante su periplo, se transmuta confusamente en esqueleto, en fantasma, en muerto, en sapo, etc. Pasa por toda una odisea: es apaleado, mordido por perros, confundido por extranjero. En resumen, se trata de un viaje insólito, un viaje donde las fronteras entre la locura y la realidad se entremezclan y se borran. Somos testigos de una peregrinación poética onírica, y prácticamente demencial.

Se trata de un texto disonante con el resto de su obra. No obstante, considera Lezama que "ninguno de esos delirios lo lleva a perder el sentido de su cubanía..., en sus décimas lo cubano se apodera de sus estrofas ofreciendo en el juego de lo grotesco temas que parecen de comparsa" (Énfasis añadido, "Prólogo" 345). Es decir, desde su nacimiento, lo cubano tiene también de enajenación y de grotesco. Resulta entonces que el poeta inaugural de la "autóctona" cubanía con su oda "A la piña", cuenta en su arsenal con otra composición igualmente destacada que permite identificar otra manera de ser cubano, donde lo destacado es lo vago, lo siniestro, y lo individual, más allá del discurso político, situándose "en un tiempo meramente poético, liberado de toda circunstancia cronológica" (Lezama Lima "Prólogo" 346).

La influencia de Zequeira, y de este texto fundador es fundamental. Tanto es así que Arcos distingue en Zequeira al antecesor de los otros dos líricos más importantes del siglo XIX, José Martí y Julián del Casal, con estas palabras: “'La ronda’ es el texto más raro para comenzar una literatura nacional: con un 'yo' inicial que puede anticipar el de Versos sencillos de Marti'”. Y agrega que Zequeira siente, a la vez, "ese frío que muchos 
años después distinguirá a Casal” (Énfasis añadido, "Notas sobre Cuba y España”). Se observa entonces cómo el poema puede reclamarse para el discurso alternativo y redimensionarse a la luz de la crítica cubana actual por su simbolismo como viaje de enmascaramiento, invisibilidad y desidentidad. La importancia de esta composición poética es trascendental, pues es la primera en plasmar lo cubano a través de un universo individual y de vivencias personales, al margen de atributos patrióticos. Tiene razón Arcos cuando plantea que en "La ronda" hay "otra manera de leer de nuevo nuestra literatura, no desde la perspectiva de la revelación de la nación y de la identidad, sino todo lo contrario" (Énfasis añadido, Desde el légamo 58).

Ese enmascaramiento llega al punto de insinuar travestismo en un fragmento de las décimas. Según recuerda Pedro Marqués de Armas, en la época, el Reglamento de policía tenía establecido que "ninguna persona andara [sic] por las calles disfrazada, ni con el rostro cubierto o enmascarado, pena de diez ducados" (cit. en Ciencia y poder en Cuba 40). De esta estricta norma se libraban los que realizaban las patrullas nocturnas por las garitas que rodeaban la ciudad, pues "este recorrido de policía era efectuado por una 'patrulla de regidores disfrazados'; no en balde es un grotesco matasiete quien le sale al paso al esqueleto en que el autor se convierte y dispone enviarlo al 'gabinete de la historia natural"”, y de esta manera—advierte Marqués de Armas—Zequeira deja ver en su composición como "el poder mismo se ejercía como voluntad de travestimiento" (40). Para terminar con Zequeira, y apelando a una profusión de imaginación por parte del lector, se puede apreciar en el siguiente pasaje del poema lo que bien podrían ser disimuladas evocaciones eróticas: 
Después que entregué el marrón

Vi sirviendo de tintero

Un casco como mortero,

Y por pluma había un cañón:

Al firmar, sin dilación

Mi pluma luego se ecsita [sic],

Y en la espesura infinita

Que el cañón tenía en su talla,

Una rígida metralla

En vez de tinta vomita (253). (Severino Boloña Colección de poesías)

Heredia. El José María Heredia político, tornadizo y azaroso, ha copado casi todo el esmero de sus cronistas. Menos conocido resulta el alcance de su influencia lírica. Parece que aquel "torbellino revolucionario" de la vida y obra del poeta, le apartaba de todo lo que no se refiriera a la liberación de los pueblos y sus anhelos. Sin embargo, durante su primera estancia en México para cursar la carrera de Derecho, los elementos culturales que se respiraban en el país preparan al Heredia del porvenir. La influencia de los poetas salmantinos, el clasicismo formal del siglo XVIII, que contrastan con su espíritu y que observamos con extrañeza en su obra, pueden expresarse por el ambiente humanístico de la época.

Ya en 1915, el filósofo, abogado y ensayista José María Chacón y Calvo, aborda un tema poco recurrido de la vida y obra del poeta: su erotismo. Para el crítico, ese lirismo de la obra de Heredia vendría a constituir un demérito, un defecto, pero lo 
justifica mediante el sofisma de que "muchos de los defectos de Heredia (el falso sentimentalismo, el erotismo exterior...), ... se explican por el influjo de los poetas salmantinos. ... Es menester comprobar ese ambiente humanístico" (246). Esa "ligereza" se aprecia en su poema "La partida" ¡Eres humana y yo soy infeliz !..., en mi destierro en fiestas mil de juventud forzosa viviré entre dolor, y tú cercada que abrasará de tu beldad el brillo, me venderás perjura, y en nuevo amor palpitará tu seno, olvidando del mísero Fileno la fe constante y el amor sencillo. (cit. en Chacón 255)

De esta manera, Heredia es con igual fuerza un poeta erótico y es un poeta social. Su erotismo es físico, exterior. Su poesía social, oratoria en la forma, es de fines utilitarios. Y así se multiplican los ejemplos: "La estrella de Cuba", "El himno del desterrado", su largo poema "Las sombras", su oda "Contra los impíos" ofrecen el mismo carácter. Todas estas composiciones oscilan entre el estilo prosaico y el oratorio (Chacón y Calvo 255).

Heredia, poeta del presente y futuro, poeta nacional por antonomasia, escribe "Desamor", poema apasionado, pero prosaico y de puro erotismo físico: ¡Salud, noche apacible! ¡Astro sereno, bella luna, salud! Ya con vosotras mi triste corazón de penas lleno viene a buscar la paz! 
Del sol ardiente

el fuego me devora.

Sola tu luz. . . sabe halagar mi corazón. (Niágara y 27).

En su poema "La inconstancia", nos encontramos frente a una lírica rayana en lo prosaico.

... Mas ¡ay! el alma,

Que fina te adoró, falsa te adora.

No vengativo anhelaré que el Cielo

Te condene al dolor: sé tan dichosa

Cual yo soy infeliz; mas no mi oído

Hiera jamás el nombre aborrecido

De mi rival, ni de tu voz el eco

Torne a rasgar la ensangrentada herida

De aqueste corazón: no a mirar vuelva

Tu celeste ademán, ni aquellos ojos,

Ni aquellos labios do letal ponzoña

Ciego bebí. . . !Jamás! (Niágara y 15)

Martí. En el limitado espacio de este proyecto se precisa abordar, aunque sea someramente, un aspecto poco divulgado (por controversial) de la vida de Martí, un rasgo que bien puede trazar pautas posnacionales en el proceder de Martí, pues discurre en cuestiones intimistas, separadas en todo de la política, y que toca temas como la sexualidad, dejando de lado los avatares políticos. Es el hombre tras el mito, sensual, eufórico, pesimista: ¿Posnacional nihilista? 
En la literatura ocurre que, en ocasiones, parte de la obra marca a su autor encasillándolo. Típico ejemplo es el de José Martí. El discurso crítico ha favorecido lo épico y grandioso sobre lo sensible, envuelto en una santidad que dispersa y esconde los inevitables defectos propios de su condición humana. Político por excelencia, Martí dedicó su vida pública a la causa de la independencia y soberanía nacionales. Sin embargo, tras los alegatos, partidos, expediciones y combates, existe el elocuente expositor de otras necesidades del ser humano que ostenta a su peculiar manera. No se pretende incorporar anécdotas al mito de José Martí al que estamos acostumbrados, ni dialogar con la levedad o gravedad de su discurso, sino acercar al Martí febril y precursor del actual movimiento posnacional, transfigurando lo mesiánico en lo íntimo:

Como una enredadera

Ha trepado este afecto por mi vida

Díjele que de mí se desasiera

Y se entró por mi sangre adolorida

Como por el balcón la enredadera. (cit. en Quesada y Miranda 102)

Hay una poco divulgada y menos apreciada historia, plagada de riqueza espiritual, que tiene en Martí al "hombre" sensible y apasionado desde sus primeras inquietudes y con una sufrida vida sentimental. Hombre atormentado entre, por un lado los deseos de ver a su patria libre del imperio español y evitar a toda costa que el imperio norteamericano tome el lugar peninsular, y por otro llevar una vida placentera en pasiones porque “sin pan se vive; sin amor, ¡no!” (Obras completas 21:114), Martí deja un legado rico en alusiones sobre lo erótico. Compleja mezcla de romántico y político 
cabal e ilustrado, es Martí el emigrante expatriado, el enérgico incansable y tenaz, el mismo que va a luchar por su patria en 1895 , quien, en franco abatimiento por la reciente muerte de María García Granados, le escribe el 6 de julio del 1878 a Manuel Mercado desde Guatemala:

Ayer mismo, sobre los ruegos de Carmen que lloraba, sobre lo que mi madre llora sin decírmelo, sobre mi palabra misma empeñada al generoso Zayas, me resistía a todo intento de ir a Cuba, y tenía firmemente decidido ir a Perú. ... ¡Creen que vuelvo a mi patria! ¡Mi patria está en tanta losa abierta, en tanta gloria acabada, en tanto honor perdido y vendido! Ya yo no tengo patria. (Obras completas 20:53)

Fue Martí desafortunado en afectos. Desde sus primeros desvaríos juveniles, su relativa y escasa felicidad al lado de su esposa, el silencioso amor por María García Granados y la discreción que envolvió la relación con Carmen Miyares así lo confirman. Cuando el capitán Enrique Satué revisa el cadáver caído en Dos Ríos, encuentra—entre documentos de la guerra — cartas amorosas de Carmen Miyares, su Carmen. Sus amores, ya hayan sido efímeros, alejados, secretos, fatales, o pesimistas, no le impidieron declarar el 26 de abril de 1895 en misiva a la propia Miyares: "poco hace en el mundo quien no se siente amado", y esto revelado apenas un mes después del Manifiesto de Montecristi, muy lejos del pragmatismo exacerbado en aras de la libertad, y a las puertas (el 19 de mayo) de su muerte.

Desde temprana edad, a raíz de su destierro a tierras españolas, Martí comienza sus lides eróticas, la apreciación del organismo, los modelos sobre masculinidad y feminidad, y su papel social. En su cuaderno de apuntes No. 2 escribió: "Pasión por el 
deber: preferencia por el martirio voluntario, esto es el alma que asciende. Lo otro es cuerpo que retiene. Esa clase de cuerpo que hay que vencer". Por su parte, en su Cuaderno No. 3, escritos entre el 1874 y el 1878, aparecen las primeras observaciones sobre el amor sexual cuando escribe: "la amistad no excluye nunca la libertad de criterios" (Obras completas 21:114). Es en España donde escribe su pieza teatral Adúltera, empezada cuando contaba con 19 años y publicada dos años después. Según sus propias palabras "a los 18 años de mi vida estuve por las vanidades de la edad, abocado a una grave culpa" (Obras completas 28:105). Su novia zaragozana Blanca de Montalvo le atemperó la juventud antes de partir a reunirse en México con sus padres y hermanas. Ella fue la que le inspiró su primer cuento "Hora de lluvia", y también se convertirá años más tarde en memoria de sus Versos Sencillos (Santos Moray, "España”).

Catorce años más tarde, en la soledad, el desasosiego y el cansancio, bajo la crudeza del invierno neoyorquino, que lo hace peregrinar hacia las frondosas montañas de Catskill, escribe sus Versos Sencillos, donde añora aquellos primeros goces placenteros de la carne: "Amo la tierra florida / Musulmana o española / Donde rompió su corola / La poca flor de mi vida" (Obras completas, "VII" 16:77). En México, Martí se dedica al teatro y a las tertulias literarias. Su poema "Nocturno" está inspirado en su amor por Rosario de Acuña, mujer fatal responsable del suicidio erótico y no correspondido del lírico Manuel Acuña. El proverbio “Amor con amor se paga” lo escribió de un tirón por otro de sus apegos, la actriz Concepción (Concha) Padilla.

En misiva dirigida a su amigo Manuel Mercado en 1877 habla sobre lo significativo de conciliar el deber asumido con los sentimientos naturales: "Hago lo que debo y amo a una mujer, luego soy fuerte" (Obras completas 20:26), tema que lo inquieta 
y deprime. Ya desde 1876 viene tratando sobre la avenencia de las necesidades, escribe en El Federalista: "El fin de la vida no es más que el logro difícil de la compensación y conciliación de las fuerzas vitales" (Obras completas 6:367). La pugna interna entre disfrutar de los placeres y el deber patrio se acrecienta en el 1887, cuando redacta para el periódico argentino La Nación: "Es natural y humano que el hombre piense constantemente en sí.... Y procure conciliar su adelanto personal y la utilidad pública" (Obras completas 13:161). En 1891 escribe en su Cuaderno No 5, refiriéndose erótica y casi groseramente al órgano viril masculino: “ $\mathrm{Y}$ tantas cosas nobles cómo pudieran hacerse en la vida! Pero tenemos estómago. Y ese otro estómago que cuelga; y que suele tener hambres terribles" (Obras completas 21:160). La necesidad de afecto en Martí es recurrente y altiva. En 1886 postula: "Solo saca de sí su fuerza entera el que vive en la arrogancia interior de ser querido" (Obras completas 13:171). Pero no es el afecto recíproco el que lo atrae, es la incondicionalidad, el acatamiento que le permita perseguir sus avatares y apoyen sus alternos estados de ánimo: “¿Debo correr aventuras que repugno? ¿Podré yo tener todo el aliento que necesito lejos de aquella para quien lo quiero?" (Obras completas 20:20).

El 9 de abril de 1895 Martí se encuentra en plena efervescencia antes de arribar a suelo patrio dos días después y cumplir con su mesiánico empeño de ver una nación emancipada. Entre comunicaciones con los altos mandos de la guerra por venir y la organización de la contienda, firma una extraña misiva a su Carmen Mantilla: "La lealtad es la felicidad cuando no se la exagera, como yo la exageré. Los chinos dicen que en nada debe haber exageración: ni en las virtudes" (Obras completas 19:235). Faltan aún la 
amargura de La Mejorana y los gritos, acallados por Gómez, de “iMartí Presidente!” (Obras completas 19:238). Faltan apenas cuarenta días para su muerte.

El erotismo de la narrativa martiana va incluso un poco más allá, y se sitúa en las lindes de las relaciones lésbicas. En Nosotras dos, antología publicada en Cuba en 2011, y en la cual por primera vez en la historia de la literatura cubana se recogen “cuentos de mujeres que se aman, o que tienen algún tipo de relación íntima más allá del sexo" (7), la editora Dulce María Sotolongo aporta un ángulo nuevo a la manera tradicional de presentar la figura de Martí dentro de la isla. Sotolongo menciona de pasada en el prólogo cómo la génesis de la literatura homoerótica en la isla quizás pueda encontrarse en Amistad funesta, obra que revela "cierta ambivalencia sexual entre los personajes Lucía y Sol” (Nosotras dos 7).

Hay que recordar que esta "noveluca", como el mismo Martí le denominó despectivamente (su primera y única novela), escrita "durante siete días, interrumpido a cada instante por otros quehaceres" (Obras completas 18:192), fue hecha por encargo y salió por entregas en el periódico El Latino Americano de Nueva York en 1885 bajo el seudónimo de Adelaida Lar. Explica Gonzalo de Quesada y Aróstegui, albacea de la obra literaria de Martí y a la sazón Secretario de la Delegación del Partido Revolucionario Cubano (PRC), que él mismo la descubrió por casualidad traspapelada en la oficina, y al preguntarle a Martí sobre la procedencia de dichas hojas, este les restó importancia con estas palabras: "guárdelas para otra ocasión. En este momento debemos solo pensar en la obra magna, la única digna: la de hacer la independencia" (Obras completas 18:188-9). 
Advierte en un prólogo posterior Martí la inconformidad hacia su propia novela cuando la llama "puro cuento. . . que el autor piensa muy mal de él. Lo cree inútil; y lo lleva sobre sí como una grandísima culpa. Pequé, Señor, pequé, sean humanitarios. . . no lo haré más" (Obras completas 18:192). Y ciertamente su inconformidad parece que fue tanta que Amistad Funesta quedará como la solitaria incursión de Martí en el género novelístico. Ya Rojas nos advertía al decirnos que a Martí "se le hizo por momentos insoportable alternar la escritura de la poesía con la fundación de un Estado" ("El intelectual” 4).

La investigadora Patricia Valladares Ruiz abunda un poco más en la naturaleza de las relaciones entre Sol y Lucía, personajes femeninos protagónicos de Amistad funesta entre los que "surge una relación marcada por sentimientos tan ambiguos como recíprocos. . . . La inocencia y vulnerabilidad de Sol la hacen víctima de los celos desmedidos y obsesivos de una Lucía que mucho tiene de los rasgos esquizoides y perversos tan asociados al lesbianismo durante el siglo XIX" y agrega que “deliberadamente o no, Martí nos propone unas fronteras muy frágiles entre las manifestaciones de amor fraternal y sensual" $(21,24)$.

El peso de conciencia parece resolverlo Martí con períodos de depresión que alternan con otros en los que está extremadamente feliz o malhumorado o irritable. Como plantea Omar Ette, este recurso lo utilizará una y otra vez en sus alocuciones y textos, cargados de un peculiar lenguaje "oscuro y simbolista, la lengua que hablan los profetas y los videntes" (1). Volpi, en su interesante ensayo "Yo soy una novela", ilustra: La idea del yo, ese incómodo testigo que al presenciar los hechos nos separa de ellos, es, ya lo apunté, la más compleja y la más frágil. Porque 
el yo siempre se haya solo. Irremediablemente solo. Su única escapatoria consiste en identificarse con ese otro conjunto de ideas complejas que son los demás, sean estos reales o imaginarios. Y, paradójicamente, ese contacto virtual es nuestro único escape del autismo o la demencia. (54)

El 11 de agosto de 1877 Martí escribe a su "amigo muy querido" Manuel Mercado: "hoy andan de paseo las alegrías y están tenazmente despiertas las tristezas. . ., si fueran piedra preciosa, serían ópalo" (Obras completas 20:30). Es a este imaginario arraigado de José Martí, dentro del contexto originario, lo que Slajov Zizek cataloga como la relación entre la fantasía y los antagonismos inherentes a la edificación ideológica (El acoso de las fantasías 11). Las personas reales (vivas o no) son transformadas en meros instrumentos, sacrificadas ante el espectro de un futuro "hombre nuevo".

Casal. Otro tanto ocurre con Julián del Casal (1863 - 1893), quizás la figura precursora por excelencia del escritor cubano posnacional, y uno de nuestros poetas y prosistas más acentuados. De él se dijo en 1963 con motivo de la edición por vez primera de la recopilación de su prosa: "para el regocijo de nuestros hijos, en la luz, se hace esta edición”. José Manuel Oviedo, en su magnífico apartado sobre el modernismo en el tomo 2 de su Historia de la literatura hispanoamericana, se refiere a un aspecto poco tratado dentro de los estudios casalianos: el erotismo homosexual que se puede identificar en algunos de sus versos. Empecemos entonces citando el breve repaso de Oviedo sobre este tópico:

Hay que sumar un hecho que ha sido velado por la crítica y solo muy recientemente sometido a examen: el de la homosexualidad del poeta. 
En La Habana colonial de esos años éste era un tema que no solía hablarse o se hablaba en voz baja y tono condenatorio. Del Casal se cuidó muy bien de revelar lo que, para sus amigos inmediatos, debió de ser algo conocido. Esto hace que sus referencias a lo sexual, frecuentes en un poeta erótico como él, tengan a veces un carácter extremadamente ambiguo y oblicuo. En "Autobiografía”, de su primer libro, hay alusiones que, si se leen entrelíneas, pueden significar algo muy distinto de lo que parecen: ¿cómo hay que entender su recuerdo a “mis amantes compañeros”? ¿Y qué nos dice realmente esa imagen de la opresión que siente "cual si en mi pecho la rodilla hincara! joven Titán de miembros acerados”? Y si en "A la castidad” proclama esa virtud, ¿queda por ello absorbido todo el alcance de los primeros versos: "Yo no amo la Mujer, porque en su seno / dura el amor lo que en la rama el fruto"? No menos ambivalente es su crónica de 1889 sobre "El Centro de Dependientes", donde defiende la institución pero sin señalar que había sido denunciada por ciertas prácticas sexuales que se realizaban allí. El discreto silencio que guardó del Casal crea un inquietante vacío en su obra y es una señal en negativo de la múltiple marginación que tuvo que sufrir en su vida. (“Albores del modernismo" 255)

José Martí, en su escrito aparecido en el periódico Patria del 31 de octubre de 1893, le rinde escueto homenaje, edulcorando la imagen del poeta que acaba de morir, desajustada con el modelo masculino del patriota, al enunciar: "de la beldad vivía 
prendida su alma; del cristal tallado y de la levedad japonesa; del color del ajenjo y de las rosas del jardín” (“Julián del Casal” 225). Sin embargo, poco nos habla la historia de ese Julián crítico, político, arriesgado, que toma las páginas de La Habana Elegante para fustigar, bajo el alias pretencioso de Conde de Camors, a la sociedad habanera del siglo XIX, quizás con más valentía que ningún otro cronista. De su pluma no escapó siquiera el Capitán General de la isla Sabás Marín, al que se refiere en una de sus crónicas de esta guisa: "El General [refiriéndose a Sabás Marín], se ha hecho antipático a sus subordinados. Tanto la prensa, a quien persigue tenazmente, como el comercio, a quien no ha querido escuchar, lo han dejado en el más terrible aislamiento. Todos comentan desfavorablemente sus actos gubernamentales" (Prosas 1, 57). Este artículo, por cierto, le costó su puesto como modesto escribiente de la Intendencia General de Hacienda. ¿No es precisamente Casal quien pone nerviosos a los del Círculo Habanero, a tal punto que lo censuran en comunicación del 6 de abril de 1888? Casal es un patriota con bríos diferentes. Su refinamiento y sensibilidad hastían y son a la vez causas de admiración y rencores.

El 1 de julio de 1890 en La Habana Elegante ${ }^{28}$ sale un artículo de Enrique José Varona comentando el primer poemario de Casal Hojas al viento. En él concede que el poeta "joven de temperamento artístico exquisito. . . perdido en medio de una sociedad que no realiza. . . su concepción de la vida", se refugia "en el mundo ideal de los libros", a partir de los cuales es capaz de crear "obras vigorosas, con vida que nada tiene de

\footnotetext{
${ }^{28}$ Revista cubana que se publicó entre 1883 y 1896 en La Habana. Importante difusora del modernismo hispanoamericano. Julián del Casal se incorpora en 1885 y publica en la revista, de acuerdo con Francisco Morán, lo más significativo de su obra. Véase del propio Morán el ensayo "Nuestra historia. Surgimiento de La Habana Elegante".
} 
ficticia”. Sin embargo, más adelante Varona ataca lo mismo que antes había alabado, es decir, que de la cultura libresca Casal haya elaborado una obra vigorosa. Ahora, al faltarle el elemento patrio, el "influjo decisivo de las reminiscencias de lo leído" es más bien un inconveniente, lo que se aprecia cuando apunta en tono desdeñoso:

Aquí empieza lo insólito del caso del señor Casal, y lo que nos autoriza a llamar artificial el medio puramente subjetivo en que se alimenta su inspiración. En su espíritu flotan visiones que nada tienen que ver con nuestra vida pasada: trovadores vagabundos y castellanas melancólicas. . . ; conventos en ruinas y monjes sombríos... y llega hasta contemplar pastorcillas rubias bajo el sol tropical o a la sombra de los plátanos rumorosos. ... Ese amor le ha venido por el canal de sus lecturas; puesto que ellos nada han podido dejar en nuestras costumbres, en nuestras tradiciones, no perteneciendo a nuestra historia. (Énfasis añadido, cit. en Morán, Julián del Casal (in memoriam) 24)

Se debe recordar para cerrar esta sección las palabras de Vitier cuando enjuicia la poética de Casal como "suma de cosas exquisitas y raras, de sensaciones decadentes y voluptuosas, hijas mentales del tedio, la sed de lo extraño, y la neurosis" (Lo cubano en la poesía 242, 268). Certeramente apunta Francisco Morán que "lo que se exige a Casal—y en lo que Casal no cede—son pruebas de patriotismo vehemente, golpes de pecho, certificado de nacionalidad" (Julián del Casal o los pliegues 226). Se puede percibir como el canon desde nuestros incipientes ejercicios críticos, pasa por el filtro del patrón nacionalista heterónomo como requisito de admisión. Los escritores 
posnacionalistas cubanos recurrirán al homoerotismo como desagravio por tantos años de marginación.

III. 2. Los nuevos contornos literarios en la narrativa nacional actual

¿Don Quijote y Pedro Picapiedra, Hamlet y Lulú, Darth Vader

y Dumbo, Mario y Luigi existen solo para transcurrir horas aciagas, para apresurar la noche y el sueño, para impedir quepobres de nosotros - nos vayamos a aburrir? Sonaría inverosímil: una especie no gasta tanto dinero y tantos anhelos en una actividad que sirve nada más que para colmar las horas muertas. Los humanos somos rehenes de la ficción. Jorge Volpi. ("Yo soy una novela").

Preguntaba Roger Bartra en 1987: “¿Vamos a entrar en el tercer milenio con una conciencia nacional que es poco más que un conjunto de harapos procedentes del deshuesadero del siglo XIX?” (La jaula de la melancolía 18). Creo que nuestras últimas generaciones de escritores nos están ofreciendo ya los elementos necesarios para que empecemos a elaborar una respuesta. Aunque pueda parecer lo contrario, el posnacionalismo también se impone a veces por pura arrogancia. El irlandés James Joyce y el alemán Arno Schmidt hicieron lo que nadie se había atrevido a hacer antes:

desafiando las prohibiciones nacionales y las cuestiones obligadas, impusieron su lengua y su gramática, su discontinuidad narrativa, derrocaron a las jerarquías de los panteones nacionales (Casanova 428).

Los escritores latinoamericanos, a partir de los noventa, comienzan a cuestionar la homogeneidad de las culturas nacionales y critican abiertamente la idea misma de nación. En una frase, se suman a las tendencias de globalización. En buena parte de la literatura hispanoamericana actual "podría leerse una visualización visceral y a menudo traumática 
de la posibilidad o imposibilidad de los vínculos entre literatura y nación”, a través de una narrativa que "postula una identidad mutante, que se urbaniza, se vuelve fronteriza, híbrida, apocalíptica, multiterritorial, universal, posnacional, etc.” (Esteban 10).

Teniendo en consideración que nacionalismo y posnacionalismo son términos vinculados entre sí, y luego de haber llevado a cabo un repaso diacrónico, siquiera breve, de las dos principales corrientes y teorías nacionalistas existentes en el pensamiento cubano, a partir de ahora y en el resto de nuestro trabajo se tratan las propuestas que en los ámbitos prácticos, teóricos y estéticos tratan de explicar el surgimiento, desarrollo y auge del fenómeno posnacional en Cuba, especialmente en la narrativa.

Para empezar, es necesario tener en cuenta que el posnacionalismo cubano se inserta, en un plano más general, dentro de la corriente posnacional que recorre el resto del continente latinoamericano. Es decir, no solo cree que la organización en estados nacionales ha quedado obsoleta desde un punto de vista institucional o económico sino que, además, considera que el alcance de la moral, la estética o la cultura debe ser mundial y puede empezar a serlo gracias a fenómenos como el desarrollo de los medios de comunicación y transporte, la globalización económica, los movimientos migratorios masivos o las amenazas globales. La literatura posnacional, en consecuencia, y como plantea Castany Prado "tiende a dar cuenta no tanto de una sociedad nacional como de una sociedad mundial. Sus estrategias narrativas y estilísticas así como sus temas y símbolos ya no cuentan la historia íntima de las naciones, sino la del mundo" (12).

La globalización—según la tesis de Castany Prado—abrió una profunda crisis en la política, la sociedad, la cultura y el conocimiento. Sin embargo, a pesar de que las colectividades "se repliegan y endurecen ... y de una profunda crisis de criterio", 
Castany reprocha que "nos seguimos hallando con una negativa radical a replantear[nos] conceptos modernos como los de estado-nación, ciudadanía, identidad o racionalidad" (84). Es decir, los marcos para pensar la nación todavía no son totalmente globales. Cada vez más, por otra parte, el descentramiento de lo nacional pone en tela de juicio la idea misma de la importancia de los lazos entre territorio, lengua, cultura y nación.

A lo anterior se suma el desmoronamiento del socialismo real y el descrédito de las utopías, aspectos que han influido en la manera en que los escritores, en especial los nacidos a partir de 1960, desarrollan su escritura: a diferencia de sus predecesores, ninguno de ellos se muestra obsesionado por la identidad latinoamericana $-\mathrm{y}$ menos por la mexicana, boliviana o argentina — aun si continúan escribiendo sobre sus países o incluso los de sus vecinos (Volpi, El insomnio 168). El forcejeo en los límites-como se verá en el caso de Anna Lidia Vega Serova-y el ensanchamiento de las fronteras temáticas de lo nacional al darle la espalda o simplemente ignorarlas-como ocurre en los casos de Karla Suárez y Ena Lucía Portela—-, demuestran que lo nacional no puede ser ya un objeto de imperiosa lealtad, sino una alternativa entre las varias de las que dispone un autor a la hora de construirse una identidad y de vincular su obra a un contexto determinado (Guerrero 80-1).

Dentro de las artes, ha sido la literatura, especialmente la prosa, y dentro de ella la ensayística, la más lastrada por la cosmovisión nacional, siendo en consecuencia un factor importante de construcción comunitaria (Anderson 11). Esta cosmovisión nacional representa un freno a la renovación y al intercambio de las ideas y las formas, un empobrecimiento de las capacidades críticas al subordinar el criterio estético al geográfico (Castany Prado 10). En Cuba la subordinación suma al criterio geográfico, el 
ideológico y el político. El espacio disponible para las artes en general y la literatura en particular ha privilegiado el punto de vista de "que todo escritor debe representar y dirigirse, sobre todo, a su propia sociedad nacional" (Castany Prado 1).

Para comprender la existencia—e insistencia—de la tendencia posnacional en la literatura contemporánea cubana actual, se ha partido del peso fundamental que los postulados nacionalistas han tenido - y continúan teniendo — en la disposición del ideario nacional. Dicho esto, hay que reconocer que algunos escritores continúan, incluso en los primeros años de euforia revolucionaria, expresando sus ideas y publicando en la isla sin plegarse dócilmente a las exigencias oficiales. Para lograr lo anterior, llevan a cabo su labor intelectual mediante lo que Ernesto Méndez y Soto denomina "las distintas formas de evasión" (180). Dentro del marco general de evitar entrar en conflicto con el ideario político de la revolución, una primera manera de evasión es "condena [ando] las contradicciones de la sociedad capitalista" y una segunda manera es abordando "temas ajenos a la realidad social de la Cuba comunista" (180). Unido a lo anterior, otras maneras de evasión incluyen la utilización de recursos narrativos que conceden preferencia a los aspectos formales del relato, dígase el monólogo interior, el tratamiento especial del tiempo narrativo, la narración en segunda persona y el uso del lenguaje. Como consecuencia, la materia narrativa-refiere Méndez y Soto-queda relegada a un segundo plano dentro del diseño estructural del relato" (180).

En su excelente ensayo Méndez y Soto compila a veintitrés autores y treinta y tres obras (publicadas en Cuba algunas y otras en el exilio) en la década del sesenta, que de una manera u otra se pueden ubicar dentro de la alternativa de la evasión, por oposición a la otra, que podríamos denominar la obligación del compromiso. Un botón de muestra 
que sirve de precedente a la literatura posnacional que se estudia en esta disertación, en el sentido de novela cuyo referente geográfico y temporal se aparta de la nación, se encuentra en El siglo de las luces, de Alejo Carpentier. Aunque no existe conexión causal entre una y otra revolución, la novela no solo explica el impacto de la revolución francesa en el Caribe, pues puede ser también entendida como una demoledora crítica contra todas las revoluciones (de la que ciertamente la Revolución cubana no sería una excepción), empezando por el entusiasmo y deslumbramiento del principio al cruel desengaño del final.

En el ámbito latinoamericano, durante la segunda mitad del siglo XIX y la primera mitad del XX, los letrados de las distintas naciones se obsesionaron-plantea Jorge Volpi-con encontrar su "esencia". De allí el surgimiento de una tradición nacional que se oponía, a veces con rabia militante, a la de los escritores "cosmopolitas". Entre los autores cosmopolitas que se destacaron a partir de los años cuarenta del siglo XX, Jorge Volpi propone incluir a Juan Rulfo, Juan Carlos Onetti, Alejo Carpentier, así como también a Carlos Fuentes y Mario Vargas Llosa. Ellos son autores cosmopolitas en la medida en que en "vez de permanecer atados a sus respectivas tradiciones locales, ... preferían mirar hacia afuera e incorporar recursos de la moderna novela europea y estadounidense a sus propias creaciones" (El insomnio de Bolivar 167). Como se aprecia, la confrontación entre estas dos posiciones, por un lado el fundamentalismo nacional y por otro el cosmopolitismo, tiene larga historia en el tiempo y no está limitada al marco de la mayor de las Antillas.

La novísima narrativa latinoamericana, heredera y familia de la tradición cosmopolita, podría emparentarse con la acepción posnacional en la medida en que es 
una narrativa que rehúsa ser limitada por sus orígenes nacionales y que deliberadamente busca un lugar de encuentro con otras tradiciones literarias y culturales (A. González, "Más allá" 52). Los nuevos narradores evitan el romanticismo o el compromiso político militante, y sus actitudes frente a la historia o el futuro no pretenden definir o tener la última palabra. No es ocioso aclarar que esto no significa que la nación haya desaparecido como escenario o centro de interés, pero sí que "empieza a ser percibida con un carácter posnacional, desprovisto de una identidad fija. Es decir se alejan de la ideología que los lleva a preservar los parámetros de la literatura nacional” (Volpi, El insomnio 176).

Cuando la literatura consigue deshacerse de su dependencia política, solo admite su propia autoridad, desentendiéndose, entre otros, de los antiguos patrones establecidos. Esta escritura, a través de los nuevos actores posnacionales, y coincidimos aquí con Rafael Rojas, se halla "desprovista de una sensación de legado" (cit. en Ordoqui 1). El poeta David Lago González ha expresado limpia y crudamente, a nuestro parecer, esa sensación de desidentidad y desafección hacia todo, pero sobre todo a lo que huela a Revolución, reconociendo solo el compromiso con su arte cuando expresa:

Nunca hice nada por la libertad de Cuba ni pienso hacerlo. No tengo obligación de ser patriota, mártir, guerrero, luchador, dirigente sindical ni militante de ningún partido, ni sacerdote ni beato, ni dama vestida de blanco o de cualquier otro color. Posiblemente eso se deba a mi falta de ideales y a un recelo ya "empercudido" hacia todo lo político e ideológico. Yo escribo versos y, a veces, pienso. ("El penthouse de Heriberto") 
Los escritores - al menos una parte de ellos—-pueden entonces negarse, tanto colectiva como individualmente, a aceptar la definición nacional y política de la literatura (Casanova 58-9). Aníbal González incorpora igualmente la idea de la pérdida o ausencia de nostalgia en esta nueva hornada de literatos: "El rechazo de la nostalgia se ha vuelto un gesto colectivo en grupos de escritores latinoamericanos. Las actuales obras de ficción narrativa... buscan ir más allá de la nación como su marco principal y su razón de ser y. . . para ello, buscan apartarse de la nostalgia con la cual se ha entretejido el discurso de la identidad nacional” (“Adiós” 83).

No podemos dejar de mencionar una importante característica de este nuevo enfoque de la narrativa, cuya pretensión final es producir textos universales tanto en la forma como en los temas que tratan. Nos referimos al concepto de cronotopo cero, acuñado a mediados de los noventa en el Manifiesto del Crack. Quizás conviene apuntar antes que el grupo del Crack fue un proyecto compuesto por cinco escritores y ensayistas mexicanos que se agruparon en torno a Jorge Volpi, y cuyos integrantes confesaban su voluntad de distanciarse no tanto del realismo mágico propio de la literatura del boom, como de los imitadores del posboom, y así "romper con una literatura radicada en una América Latina exótica, y volver a una literatura exigente, tal era su proyecto" (Chatellus 159).

El concepto de cronotopo cero, de acuerdo con estos autores, "es lograr historias cuyo cronotopo, en términos bajtinianos, sea cero: el no lugar y el no tiempo, todos los tiempos y lugares y ninguno" (Lateral. Revista de Cultura 6). Es decir, proponen y vindican el derecho de los escritores latinoamericanos a escribir novelas que pasan en 
todos los espacios y lugares, o que no tienen ni espacio ni lugar preciso. Obras, que en definitiva, abandonen las referencias a América Latina.

Las relaciones entre los cambios ocurridos en las estructuras políticas de los Estados y la conciencia nacional que se produce en el mundo occidental a partir de la segunda mitad del siglo XX, fenómeno exacerbado en la última década del período como consecuencia del derrumbe de la gran utopía, ameritan amplios comentarios, imposibles de llevar a cabo en los estrechos marcos de esta investigación. Es preciso mencionar, sin embargo, por la relevancia que tiene para nuestra tesis, una de sus principales consecuencias: la crisis de identidad que trajo consigo.

Como expone Hobsbawm premonitoriamente: “durante la segunda mitad del siglo XX hemos vivido - estamos viviendo [esto lo escribió en 1993]-la transformación social más rápida, profunda y universal de la historia humana. Y con ello todas las viejas formas de relación humana, todos los vínculos tradicionales de la comunidad, se han evaporado", para coronar con este cierre: "todos somos personas desarraigadas" (“Identidad” 16). Esta aseveración es aplicable ciertamente a la situación de Cuba, y en especial, que es lo que interesa primordialmente en este trabajo, a su poética: la literatura de la isla es, en la actualidad, una literatura desarraigada.

La cultura cubana atraviesa por una época de escepticismo ante las grandes narrativas. Habría que añadir además, un sistema político y social en bancarrota, con un régimen empeñado en negar el ocaso del pensamiento nacionalista y tratando de reinventarse para seguir sobreviviendo. Como parte de la crisis del sistema, toda práctica social, ética, cognoscitiva y estética está sujeta a fuertes presiones. Puede exponerse que los habitantes de la isla se encuentran,_-siguiendo la expresión de Castany Prado-en 
una fase de nihilismo explícito pasivo. Es decir, a pesar de la admisión abierta de que el mapa político del mundo cambió drásticamente, el aparato de poder pretende imponer la creencia de que son los demás países los que llevan un rumbo equivocado, y recurre al agotado discurso del bloqueo imperialista para justificar el descalabro en la isla.

En el terreno literario sin embargo, se puede afirmar que cada vez son más los creadores que conforman el campo de los nihilistas explícitos activos (Castany Prado 84), es decir, aquellos que aceptan abiertamente la inminente defunción de las ideas nacionalistas, construyéndose nuevos valores en una comunidad imaginada propuesta, diversa y rica, modificable y cambiante cada vez que la realidad se muestre insuficiente. No obstante, hay que advertir que la combinación Nación-Revolución no ha sido eclipsada del todo, pues la capacidad de adaptación del régimen es vasta. Así, aunque se aprecia cierta apertura para una parte de la producción cultural, la actividad creadora para los residentes en la isla continúa plagada de escollos.

Luis Alberto García, evocando la época anterior a 1989, enumera sucinta y elocuentemente los cambios que ocurrieron en la isla en los últimos años del siglo XX:

Todavía no había dólares, ni Internet, ni parabólicas, ni autos japoneses ni europeos occidentales, ni gerentes, ni choferes diplomados, ni paladares, ni prostitutas visibles, ni corruptos expuestos, ni héroes desinflados ni fusilados, ni la amplitud de los bolsillos medía el éxito, ni muros bien caídos, ni otros mal levantados, ni cuatro verdades y diez mentiras habían cambiado aún de signo. (cit. en Skodowska 108)

Ese período comienza en 1990, posterior a la caída del Muro de Berlín y es llamado comúnmente "Período especial en tiempos de paz". 
Las medidas económicas implementadas durante el "Período especial en tiempos de paz" cambiaron sustancialmente el curso de Cuba y de su literatura. Tomemos por ejemplo la despenalización del dólar, anunciada el 26 de julio de 1993. Esta medida permitió que la divisa estadounidense empezara a circular legalmente y no se castigara más su posesión e intercambio. La disposición estuvo vigente algo más de diez años, hasta noviembre de 2004, momento en el cual el uso del dólar fue descontinuado (aunque su posesión no volvió a ser considerada un delito penado por la ley), y sustituido finalmente por el peso cubano convertible (Whitfield 4). Otra de las medidas que vino a formar parte de la narrativa de la época fue la orientación de la economía hacia el turismo extranjero.

En 1994 se crea el Ministerio del Turismo y al año siguiente se promulga la Ley de Inversiones Extranjeras, con la intención de potenciar, en primer lugar, la construcción y el desarrollo de la infraestructura turística. La decisión de incrementar el turismo, a pesar de ser una fuente potencial y evidente de ingresos en divisas para el país, se había estado postergando por muchos años. Dicha demora ocurrió por las reticencias de la dirección del país a abrir el intercambio directo entre el turista extranjero y el ciudadano común debido a sus probables costos políticos, pues lo veían como una amenaza a la homogeneidad ideológica de la nación. Con la desaparición de la fuente de ingresos provenientes de la URSS y los demás países de Europa del Este se hizo forzosa la reanudación del desarrollo de este sector ${ }^{29}$. La globalización, entendida en este contexto

\footnotetext{
${ }^{29}$ Algunas estadísticas podrían ayudarnos a comprender la magnitud del fenómeno. Si la entrada de visitantes extranjeros en 1990 fue de 340.000 turistas, a mediados de la década esa cifra se había más que duplicado a 745.000, superando los dos millones de visitantes en 2004, es decir casi seis veces más con relación al principio de la década anterior. Los ingresos generados por este concepto en 1995 fueron algo menos de mil millones de dólares, duplicándose la cifra para el 2004 (Perelló Cabrera 8).
} 
como el movimiento desregulado, en su mayoría de productos a través de las fronteras nacionales, es un fenómeno al cual Cuba "came reluctantly, partially, and only as a function of the economic necessities of the especial period" (Whitfield 15). Este salto ayudó a la transformación de un país cerrado y alejado del mundo occidental por tres décadas en un país más en sintonía con su contexto regional.

El auge del turismo, con las consiguientes campañas publicitarias en Europa, puso de nuevo a Cuba en el centro de atención. Es en este ámbito, siguiendo el derrotero de otros productos de exportación, que la literatura comienza a jugar con las leyes del mercado. Los cambios en la producción editorial introdujeron la versión del auto financiamiento de la industria para las empresas estatales. Las ganancias no provendrían de libros en particular, sino de la industria en general. Los libros dedicados al consumo de los turistas que visitaban el país, así como aquellos dedicados a la exportación en divisas - entre ellos las guías turísticas, historias de la Revolución y escritos de Guevara y otros líderes - tenían que subsidiar las obras dedicadas al consumo interno. Aunque la mayor parte de la edición de libros eran educativos, la narrativa de ficción debía estar alineada con la política cultural establecida por la Revolución (Whitfield 88).

Luego del triunfo revolucionario, con la nacionalización primero de las imprentas y la posterior creación en 1967 del Instituto Cubano del Libro, la cadena de producción y distribución de libros, entre ellos los de narrativa de ficción, había estado monopolizada por el Estado. Los creadores tenían que publicar a través de las instituciones gubernamentales, de las que era impensable concebir una existencia al margen. Lo anterior, unido al hecho de una relativa estabilidad económica del régimen cubano subsidiado por el resto del campo socialista, y a la existencia de un mercado nacional del 
libro, permitía una salida a las obras de creadores siempre y cuando no fueran críticos del sistema.

En los noventa el modelo asistencial del Estado se deteriora, paradójicamente abriendo espacios para que los narradores viajen y sean editados en el exterior. Dentro del conjunto de medidas implementadas en esta década, la más significativa relacionada con la producción literaria fue el Decreto Ley 145 de noviembre de 1993, que autorizaba a los escritores a negociar con editoriales extranjeras independientemente de las editoriales nacionales del Estado. Este privilegio había sido otorgado hasta la fecha solamente a los artistas de la música, conocida en la jerga popular como la farándula. Se produce entonces un cambio en el campo cultural, entendido este en los términos de García Canclini, a saber: aquel "sistema de relaciones, que incluye a artistas, editores, marchantes, críticos, público, que determina las condiciones específicas de producción y circulación de sus productos" ("Introducción a la sociología de la cultura" 7).

El sistema de relaciones entre el artista y su obra, y los agentes sociales vinculados con la producción y comunicación de la misma (todos hasta el momento en manos del Estado), en consonancia con las mencionadas disposiciones, es alterado dramáticamente. En las cambiantes condiciones de producción literaria (que abarcan como ya se dijo la escritura, edición, publicación, distribución y lectura, entre otros), el régimen pierde el monopolio del que gozaba. Este novedoso escenario al que se enfrentan los creadores hizo posible — plantea James Buckwalter-Arias—, "the partial re-absortion of Cuban literature by a transatlantic publishing market... [that leads to a] flourishing of a pre- or extrarrevolutionary aesthetic discourse" (cit. en Whitfield 87). 
Las nuevas condiciones materiales en que se empieza a escribir ficción en la isla, unido al hecho de que no se produjera la esperada caída del régimen socialista (a diferencia de lo que pasó en Europa del Este y la Unión Soviética ${ }^{30}$ ), puso a Cuba “de moda" en el mercado literario internacional, aumentando drásticamente el interés por parte de los agentes literarios y casas editoriales foráneas. Este interés, asegura Esther Whitfield en su libro Cuban currency: The dollar and "Special Period" fiction, "culminated in the publication on an unprecedented number of Cuban-authored books and, by 1998, widespread talk of a "new Cuban boom" (55).

Otro de los mecanismos para asegurar la comercialización de la literatura desde y hacia la isla caribeña, pero en este caso sí subordinado a los intereses editoriales del Estado, lo constituyó la revitalización de la Feria Internacional del Libro de La Habana. ${ }^{31}$ A medida que se profundizó la crisis, aumentó la fecundidad y la calidad de la literatura en la isla. Mario Vargas Llosa señala al respecto: "La ficción es un arte de sociedades donde la fe experimenta alguna crisis, donde hace falta creer en algo, donde la visión unitaria, confiada y absoluta ha sido sustituida por una visión resquebrajada y una incertidumbre creciente sobre el mundo en que se vive y el trasmundo" (La verdad de las mentiras 22). Los autores cubanos (tanto los residentes en la isla como los exiliados), fueron objeto de reconocimientos y premios internacionales en toda Europa. Es en esta

\footnotetext{
${ }^{30}$ El término que utilizó el presidente cubano para referirse la destrucción del campo socialista fue "desmerengamiento", es decir, el merengue que se disuelve.

${ }^{31}$ Con un formato similar al Festival Internacional del Nuevo Cine Latinoamericano, La Habana es escenario durante una semana del mayor evento literario nacional. Cabe matizar que desde el 2002, algunas de las editoriales cubanas - Gente Nueva, Letras Cubanas, Ciencias Sociales, entre otras-, trabajan solamente para el marco ferial. El remanente del cónclave es posteriormente enviado a librerías, escuelas y demás.
} 
década cuando se reeditan, tímidamente en la isla, pero de forma exponencial en el viejo continente, las obras de autores cubanos largamente silenciados por la censura: Guillermo Cabrera Infante, José Lezama Lima y Virgilio Piñera son los más reconocidos entre ellos.

En una primera etapa, más que las técnicas literarias o las innovaciones de los escritores, fueron los audaces temas los que vinieron a sustituir a la literatura anterior. Es decir, lo que cambió fue el signo ideológico de la empresa. Según Arturo Arango, el interés de los lectores y editores europeos levantaba sospechas: “¿Es verdaderamente literario - pregunta Arango-, o tiene una base política o, incluso, sociológica? ¿Se quiere saber cómo se escribe en Cuba o cómo se vive en Cuba? ¿Qué escriben los jóvenes cubanos o cómo piensan?" (cit. por Whitfield 89).

La respuesta más acertada abarca ambas posibilidades. La base sociológica, sicológica y política que se observa en la narrativa de ficción que empieza a escribirse en la isla y a consumirse en los mercados internacionales se explica por la necesidad de esos nuevos y curiosos lectores de la realidad cubana. Es decir, desde el lado de la demanda se quiere saber qué está pasando en Cuba con lo que se podría denominar "curiosidad sociológica". Entre otras funciones, es entonces que la narrativa de ficción se convierte, además, en un vehículo de reflejo de la realidad, en una especie de cronista y sustituto del periodismo criollo. Esta fue la respuesta al vacío de credibilidad en que cayó la prensa cuando, a pesar de los cambios en la realidad político-social, continuó en su labor de alabardero del discurso oficial.

Entre los temas que se subrayan, además de la dura crisis económica, están el mundo de las drogas, el SIDA y las salidas ilegales del país. También sale a relucir el cambio de las jerarquías laborales, fenómeno que ocurre cuando los que tienen acceso a 
la divisa, ya sea por las relaciones directas con los turistas que empiezan a visitar la isla (sin olvidar las remesas de los familiares que viven en el exterior) son mejor valorados que aquellos que tienen una profesión.

La fuente del problema ya no se localiza ineludiblemente en los conflictos de clase. Lo privado es ahora lo destacable, en contraste con la dimensión social. Se reivindica el rescate del desacuerdo y de lo individual. De acuerdo con Padura, "las problemáticas abordadas son cada vez más problemáticas y todo parece indicar que los autores se lo proponen con abierta intención: lejos de complacer quieren indagar en su realidad" para luego advertir que la búsqueda estilística no va a la zaga, y ésta se manifiesta en "estilos disímiles, propuestas formales arriesgadas, búsquedas novedosas [que] conviven con la creación de obras de la más recia arquitectura clásica" (cit. en Valle 16). Es decir, la ficción del desencanto (aprovechando la calificación de Rafael Rojas), no dejó de preocuparse por la forma. Estos temas van a ser explorados bajo novedosas formas narrativas tales como la intertextualidad, la fragmentación, la abstracción, el anacronismo, el uso de la ironía y el sarcasmo.

La gran crisis del "Período especial" rompió paradójicamente las camisas de fuerza que aprisionaban a los creadores y les impedían expresarse libremente. Las protestas contra un entorno económico y social extraño, ajeno y discordante con la manoseada palabra Revolución, trae aparejado un endurecimiento del lenguaje. Se muda lo que con poca fortuna trató de imponerse en las dos décadas anteriores, el realismo socialista, en realismo sucio. Ya no quedan héroes tipo Bruno, protagonista de la novela La última mujer y el próximo combate, ganadora del concurso Casa de las Américas de 1971. En ese libro, tan celebrado entonces como tan olvidado ahora se alaba, de acuerdo 
al crítico Imeldo Álvarez "el nacimiento de una nueva conciencia [donde] se reúnen ingredientes del héroe positivo que construye el socialismo" (La novela cubana 110). De similar manera, la novela mereció el encomio de José Antonio Portuondo, influyente funcionario y comisario cultural de la Revolución en aquellos años: "realidad feliz de novela revolucionaria" en que "la imaginación creadora est[á] al servicio de una intención clara y definidamente política: exponer el proceso dialéctico del nacimiento de una conciencia socialista" (Énfasis añadido, cit. en I. Álvarez 110). La literatura como arma, como un instrumento más del arsenal político e ideológico del régimen, como herramienta de transformación social. Para decirlo con palabras del crítico Yuri Páporov: "Cofiño se esfuerza por pronunciar su palabra acerca de cómo hay que vivir, trabajar y luchar para cambiar la vida, para hacerla gozosa y feliz" (Énfasis añadido, cit. en I. Álvarez 110).

A partir de los años 90, sin embargo, son los antiguos "perdedores" quienes, a contrapelo de un régimen empeñado en la búsqueda del "hombre nuevo", comienzan a emerger en papeles protagónicos hasta ahora reservados a héroes como el antes mencionado Bruno, así como a otros de la talla de Alberto Delgado, protagonista de $E l$ hombre de Maisinicú, o Patricio Wood de Guardafronteras. Con ello se abre un abismo entre la concepción del mundo real y el "oficial", junto a la crisis de un discurso ideológico y una retórica nacionalista que resultan inoperantes. Como explica Margarita Mateo Palmer:

La ruptura que estas experiencias ocasionan en el plano ético contribuye a la fragmentación del sujeto, vinculada a su vez con la utilización de múltiples máscaras que se superponen en la vida cotidiana. Estas 
experiencias coinciden, en buena medida, con algunas ideas puestas en circulación por la posmodernidad acerca del fracaso de los grandes relatos, y se ve acompañada por una intensa crisis económica que afecta notablemente a los diferentes estratos de la población cubana. Los novísimos incursionan en zonas temáticas omitidas por la literatura inmediatamente precedente, que no formaban parte del peculiar proyecto de modernidad en que se inscribían aquellos textos. ("La narrativa cubana contemporánea” 53)

Los recién llegados, en un viaje pendular que (re)acomoda las maniobras de subversión y el legado de los "raros", (re)aparecen con una pluma transgresora, sucia y nihilista, y sorprenden al oficialismo, que reacciona adaptando lo mejor posible sus estrategias de conservación.

\section{3. Conclusiones parciales}

En este capítulo se ha estudiado la corriente posnacional en la literatura contemporánea cubana con el propósito de explorar sus límites, examinar su contenido, registrar su peso y, en resumen, establecer su presencia y relevancia como tendencia literaria en el conjunto de las letras cubanas actuales. Asimismo, se ha analizado la herencia cultural que la precedió, tratando de demostrar, al destejer el curioso entramado de los hilos que la conectan desde los mismos orígenes de la cultura cubana hasta hoy, que el posnacionalismo es una tendencia literaria legítima, tan legítima como su contraparte nacionalista. Esta propuesta se ha ilustrado a través de los notables ejemplos de Manuel de Zequeira y Arango, José María Heredia, José Martí y Julián del Casal, 
devenidos simientes de los escritores posnacionalistas cubanos de los noventa que se unen a las tendencias de globalización y surgen en desagravio ante el resonante silencio y la exclusión.

El fracaso del socialismo y el descrédito de las grandes utopías que empieza desde principios de los noventa, han influido en la manera en que los escritores (en especial los nacidos a partir de 1960) desarrollan su escritura: a diferencia de sus predecesores, ninguno de ellos se muestra obsesionado por la identidad latinoamericana. Así, reivindican el derecho a escribir novelas que puedan tener lugar en todos los espacios y lugares posibles, o que no tengan ni un espacio ni un lugar preciso, abandonando frecuentemente toda referencia a América Latina. El posnacionalismo cubano se inserta dentro de esta corriente global. Esta nueva literatura camina con pasos irregulares, unas veces firmes, otras vacilantes. Es decir, estamos en presencia de una literatura con una calidad desigual. La criatura que el canon afirmativo oficialista trató de abortar con su férrea censura vio la luz y, contra todos los pronósticos, continúa creciendo: una nueva Cuba literaria casaliana que reivindica un derecho de expresión alternativo y una cultura que reconozca al fin a los históricamente olvidados.

En el próximo capítulo se trazará un recorrido por la literatura homoerótica cubana hasta llegar al actual boom de la cultura posnacional. 


\title{
CAPÍTULO IV
}

\section{LA PEREGRINACIÓN DEL HOMOEROTISMO: DEL DOLOR A LA}

\author{
EXPLOSIÓN. CARRIÓN, CATÁ, MONTENEGRO, LEZAMA, PIÑERA,
}

ARENAS, PAZ. . BOOM.

Y sin decir una palabra, estreché su mano, cogí el sombrero y me refugié en mi soledad, donde he pensado mucho y donde pienso todavía en aquel extraño joven que, para conjurar su spleen, ha hecho del sufrimiento una voluptuosidad. Julián del Casal ("El amante de las torturas")

Aunque puede ser que estemos ante la presencia de un boom de este tipo de narrativa, ya se ha visto como los temas homoeróticos tienen sus antecedentes en escritores ilustres de nuestras letras del siglo XIX. Otro tanto sucede durante el XX, período en el cual se pueden rastrear textos que tocan tangencialmente o tienen como centro el tema de la "subjetividad homosexual".

Un libro imprescindible para adentrarse en el estudio de esta temática en la isla es La maldición: Una historia del placer como conquista (1998), del poeta e investigador Víctor Fowler, en el cual el crítico repasa el catálogo de narradores "clásicos" o establecidos y de paso menciona una "verdadera oleada" de jóvenes promesas que empezaban a descollar. Entre los primeros cita a Miguel de Carrión, Alfonso Hernández Catá, Carlos Montenegro, Emilio Ballagas, Virgilio Piñera, José Lezama Lima, Emilio Bobadilla, Calvert Casey, Reinaldo Arenas, Severo Sarduy, Antón Arrufat y Abilio Estévez. Del segundo grupo menciona, entre otros, a Senel Paz, quien con su cuento "El lobo, el bosque y el hombre nuevo" (1990), y sobre todo a partir de la adaptación cinematográfica Fresa y chocolate (1994) llevaría la literatura insular en pocos años a lo 
que considera Dean Luis Reyes "la incineración de unos cuantos tabúes que han permitido pasar velozmente de la provocación al debate franco de los rituales carnales en la Cuba de ahora", y facilitaría la entrada en una "época de oro para la evocación de los cuerpos y las liturgias sexuales en todas sus variantes" ("La fiesta de los cuerpos"). Fowler destaca entre estos nuevos pioneros de la narrativa posnacional homoerótica a Ena Lucía Portela. A ella, y a las también jóvenes promesas de los noventa (hoy mejor consolidadas) Anna Lidia Vega Serova y Karla Suárez se les dedicarán capítulos separados en esta tesis.

Carrión. En 1917 y 1919 respectivamente ven la luz dos importantes novelas de la literatura cubana: Las honradas y Las impuras, del escritor, medico y periodista Miguel de Carrión (1875 - 1929). Siempre que se producen reediciones de las obras en La Habana, desaparecen pronto de los anaqueles, lo que da una medida de cómo mantienen las mismas su vigencia. Para Alberto Garrandés "Las honradas y Las impuras [son] un dueto novelesco de lo mejor que se ha producido en Cuba a lo largo de casi cien años" (Garrandés La lengua impregnada 48). Aunque presentan una visión polarizada de la mujer de principios de siglo: "la 'buena mujer' (casada, sexualmente pasiva, sumisa, ama de casa y madre abnegada) y la 'mala mujer' (emancipada, deseante y sexualmente activa)" (Valladares-Ruiz 30), significaron un gran paso adelante en el tratamiento de la temática sexual y del cuerpo femenino en las letras vernáculas.

Victoria y Teresa, protagonistas de las Las honradas y Las impuras "son cuerpos bellos, jóvenes, tibios y deseosos" (Garrandés La lengua impregnada 42), presa de los instintos de sus propios episodios emocionales. Carrión, escritor muy influenciado y exponente del naturalismo positivista, él mismo médico, se cuida de presentar las escenas 
eróticas y de cierto morbo bajo la aureola de un aura trágica, mientras también muestra interés por ahondar en las complejidades psicológicas que subyacen detrás del comportamiento.

Victoria, el personaje protagónico de Las honradas, cuenta su trayectoria vital en primera persona. Es una mujer de buena familia, que luego de algo más de dos años de casada, engaña a su marido. Posee una educación conservadora típica de las mujeres en la época, aspecto que influye en su conducta íntima con su marido, hacia el que actúa de manera reprimida, pues es "ante todo, madre, después esposa y finalmente hija", condiciones que "casi borraron la peligrosa personalidad de 'mujer' de la cual se derivaron todos [sus] infortunios [posteriores]" (Las honradas 143). Infortunios que tienen como causa el contacto con Fernando Sánchez de Arco, hombre acaudalado, encantador y ciertamente vanidoso de la que Victoria se convierte en amante: "Yo te he enseñado a ser mujer, al poseerte por primera vez"-le asevera Fernando en un pasaje de la novela - "aunque otro haya sido el autor de tu desfloración material. Si mañana nos separásemos, a mí solo tendrías que agradecer el milagro de tu transformación” (107). El romance tiene su final cuando Victoria sale encinta y es obligada por su amante a recurrir a los servicios de una comadrona para que le practique un legrado. No hay un final trágico, y no hay una condena por las acciones de Victoria, que regresa "victoriosa" a los brazos y al amor de su marido.

Las impuras es considerada un clásico de la literatura cubana, sobre todo por la maestría con que Carrión hilvana los nexos entre la moral y el instinto. Narración donde se describe con lujo de detalles el ambiente habanero de principios de siglo, cuenta el 
viaje de Teresa, amante de Rogelio, desde un amor casto entregado sin reservas a un hombre casado, hacia el desencanto y la caída final en el meretricio.

En la obra se proporciona una pronta y explícita referencia a la práctica homosexual del protagonista masculino Rogelio quien "mostró, desde sus primeros años, un temperamento sensual e inclinado a la molicie... Tuvo aventuras amorosas entre sus mismos compañeros, que le valieron una terrible reputación; y como era osado y jactancioso, él mismo se encargaba de abultarlas, completándolas con toda clase de mentiras" (Énfasis añadido, Las impuras 55). Esta será la única referencia explícita a la relación homosexual de Rogelio, pues como se encarga de precisar Carrión, "cuando terminó el bachillerato, los amores fáciles de lupanar y algunas criaditas de su casa, cazadas al descuido, se encargaron de encauzar sus ardores por otros derroteros" (Énfasis añadido, Las impuras 55).

Interesa señalar sin embargo, que su inclinación sexual ya queda definida al comienzo, por lo que el devenir de Rogelio durante el resto de la narración podrá inferirse a partir de esa "ligereza" manifestada prontamente. De semblante jovial, era un dandy seguidor de los más insignificantes detalles de la moda, lo que "denotaba la absoluta consagración del que lo llevaba al culto de su persona". Igualmente débil de carácter, fantasioso y utópico en los disparatados proyectos que emprende, termina dilapidando la pequeña fortuna legada por su padre. Se casa todavía siendo un adolescente, sin estar enamorado, cuando Florinda queda encinta desde los primeros días de su unión y, a pesar de no "tener aún el concepto claro del compromiso que contraía. . ., se dejó conducir a la boda sin el menor disgusto" (Las impuras 56). Y así transcurre su vida entre auto lamentaciones, “iQué idiota fui! ¿Qué idiota he sido siempre!” por una 
parte y entregado a "la vida sensual y fácil de la ciudad, llena de aventureros de la política dispuestos a gozar sin escrúpulos de todos los placeres”, por la otra.

Hernández Catá. Prolífico escritor y diplomático, hijo de militar español ubicado en Santiago de Cuba y madre cubana, Alfonso Hernández Catá (1885-1940) nace circunstancialmente en Salamanca mientras su padre se encontraba en la península de permiso, y viaja a Cuba con apenas tres meses de nacido. Su padre muere cuando Hernández Cata tiene ocho años, y cuando cumple los catorce su madre lo envía a una academia militar en Toledo, lugar que abandona pronto para dirigirse a Madrid. Allí vivió en condiciones precarias por varios años, trabajó como ebanista y estudió idiomas y Psicología. Esto último le sirvió mucho en la caracterización de sus personajes. El estudio de los idiomas lo ayudó a entrar en el servicio diplomático cubano desde 1909. Representó a Cuba como cónsul en Madrid y otras ciudades de España, así como en Le Havre, en Francia, y también en Río de Janeiro, Brasil, lugar donde murió en un accidente aéreo mientras cumplía funciones de embajador de Cuba.

Este pequeño recorrido biográfico puede ayudar a explicar la vocación universal que se respira en sus obras. Además de su vocación ecuménica, Catá se afanó en reflejar en sus obras las pasiones humanas hasta "presentar casos psicológicos que lindan con lo morboso". De ahí que Salvador Bueno pueda decir que "a este escritor no le interesaba la reproducción de rasgos nacionales o regionales. La recreación localista o autoclonista estaba más allá de sus apetencias literarias" ("Prólogo", Cuentos y noveletas 10, 14). De ahí también se puede colegir que justamente por esa condición cosmopolita "tuvo que sufrir un cierto exilio: el no ser plenamente admitido ni en Cuba ni en España. En España 
se le consideró un escritor cubano; en Cuba se le negaba con frecuencia la patria literaria por españolizante” (cit. en Rius Xirgu “137. Alfonso Hernández Catá”).

Tema frecuente dentro de la producción literaria de Catá es el erótico, pero sin excederse en la sensualidad del lenguaje. Por lo general presenta la degradación o el vicio en que caen sus protagonistas con intenciones moralizantes. En el prólogo de su libro La juventud de Aurelio Zaldivar (1917), en donde se insinúa de manera ambigua el tema del homosexualismo, se refiere que la obra:

cuenta la degradación de su héroe con lenguaje tan casto, tan adolorido, que ni un momento tiene el lector la impresión de que va a leer uno de esos libros de gusto dudoso para satisfacer liviandades. .., si el autor ha puesto a tan bajo nivel al protagonista es para que su pura ansia de redención, su manotear en el vacío, su llama estéril a todas las puertas de la indiferencia, resulten más dramáticas. (cit. en Bueno, Cuentos y noveletas 8 )

Cabe mencionar otras narraciones que tratan temas similares de su autoría: Cuentos pasionales, Novela erótica (colección de cuentos y novelas cortas publicado en 1909), Los siete pecados, El placer de sufrir, etc. En 1923 se publica en Madrid El sembrador de sal, noveleta donde aparece el tema del homoerotismo femenino.

María Isabel es una joven habanera enviada por su padre a estudiar a Liverpool, Inglaterra, que en una tarde lluviosa y con unos tragos de más, es violada por su profesor de francés. Ese incidente "devastó los restos de su inocencia. Por la hazaña de aquel hombre salaz, 'el hombre' perdió su belleza para siempre” De regreso a La Habana "en su desconfianza de los hombres llegó a temer hasta de su padre, y empezó a dormir con 
Rosalía, la hija de la negra, menor que ella tres o cuatro años; pero ya formada con esa exuberancia que pone el trópico en sus obras" (El sembrador de sal 23).

Aquí los ingredientes de una trama explosiva para la época están presentes: el incesto, el sadismo, relaciones lésbicas interraciales: "Rosalía hubo de aprender a ser esclava, porque María Isabel la desposeyó de su voluntad. . ., la [sic] pegó y acarició a su antojo. ... La menor sombra de protesta desencadenaba cóleras, arañazos, penitencias crueles, desprecios y amenazas, que por las noches borraba con besos" (El sembrador de sal 24). Rosalía se convierte así simultáneamente en "esclava sexual” y objeto de adoración de María Isabel. Luego de la muerte de su padre, María Isabel calcula y ejecuta fríamente su próximo paso: casarse con un español, hombre de negocios de posición acomodada y que le doblara la edad para que se muriera pronto.

Durante la estancia en París en el viaje de bodas le es infiel al marido en repetidas ocasiones con una muchacha francesa, y cuatro meses luego del regreso a La Habana la decisión de María Isabel no deja de sorprender. Decide regresar a París ya que "no podía más, no sabía engañar, no tenía fuerzas para seguir viviendo a su lado" y lo único que quiere es irse lejos de "La Habana [que] la ahogaba" (El sembrador de sal 60). Deja claro cuando toma su decisión que no le interesa el dinero del marido, pues tendría con sus ahorros y con lo heredado de su padre.

En 1928 Hernández Catá vuelve a la carga con el tema de la subjetividad homosexual, ahora en el mundo masculino, en lo que se considera quizás como el primer libro que aborda este tópico de manera explícita en la literatura cubana. Novela que intenta apresar la agonía íntima de un hombre cuya integración social dentro de los paradigmas de "respetabilidad" se ve amenazada por una irrefrenable inclinación 
homoerótica (M. Bobes, "El homosexualismo"). En honor a la verdad hay que ser preciso, pues es en España donde se publica la novela El ángel de Sodoma ${ }^{32}$. Pasaron noventa y un años, en 2009, para que fuera editada en Cuba por primera vez. Este dato sirve como un magnífico ejemplo de la apertura que el tema de la subjetividad homosexual goza en la mayor de las Antillas en el momento actual.

El prestigioso endocrinólogo, miembro de la Academia Española de la Lengua y de la Academia de Medicina, especialista en los temas de la sexualidad, quien en 1926 había publicado "Tres ensayos sobre la vida sexual", hace una defensa de la novela sobre la premisa de que se trata de un asunto real tomado de la vida, como hace la ciencia. Marañón ve la homosexualidad como extravío, es un "problema" o "aberración", pero no debe ser criminalizada. Apoya su afirmación cuando escribe: "el homosexual es simplemente el hijo de un extravío evolutivo. No es un enfermo ni un monstruo, ni tampoco un delincuente, aun cuando pueda delinquir como el individuo de sexo más perfecto" (cit. en Rodríguez Coronel, “Alonso Hernández Cata” 12). El propósito de Marañón es doble, acoge el libro de Catá a la vez que se defiende de las interpretaciones de que sus ensayos han sido víctimas, pues sus propias obras científicas o de divulgación sobre la sexualidad estaban siendo blanco de ataques hostiles.

Marañón se adelanta a Wolfgang Iser y sus concepción sobre "el texto como una estructura potencial que es 'concretada' por el lector en relación a sus normas, valores y experiencia extraliterarios" (Selden, La teoría literaria contemporánea 74), cuando parte

\footnotetext{
${ }^{32}$ La primera impresión con una tirada de 3300 ejemplares se agota inmediatamente, y todo parece indicar que se desata un gran escándalo en la sociedad madrileña, pues la segunda edición viene "escoltada" por un Prólogo del doctor Gregorio Marañón y un Epílogo del criminólogo Jiménez de Asúa (Rodríguez Coronel, “Alonso Hernández Cata: ¿Un olvidado?” 11).
} 
del hecho de que un texto, luego de transmitido, se desliga del productor "con personalidad casi autónoma", con independencia de cuales hayan sido sus pretensiones originales. La imposibilidad de saber con certeza cómo se recibe el texto y el continuo cambio de ajustes que realiza cada lector es aún más valido cuando se trata de temas sexuales pues "el sufrimiento — consigna Marañón—sexual está tan hundido en nuestra personalidad, tan ligado a los accidentes de nuestro propio sendero, que cada cual necesita un consejero y un consejo específicos" (Zubiaurre, "Prólogo" xxi-iii).

La novela transcurre en una ciudad innominada de la que no se dan referencias específicas, ni importa darlas. Puede haber sido La Habana, pero también cualquier ciudad de Latinoamérica o de España. Se habla de hecho de "la comarca" y eso es un aspecto que la crítica ha soslayado dando por sentado que se trata de Cuba. De esa manera Hernández Catá se convierte un poco en precursor de los escritores posnacionales, en cuyas obras se desdibujan las referencias locales, y cuyas tramas son susceptibles de ocurrir en cualquier ciudad.

José-María Vélez Gomara, el protagonista, es un joven de 18 años, el mayor de cuatro hermanos (dos varones y dos hembras) de una familia venida a menos. La madre ha muerto hace unos años, y el padre acaba de suicidarse para que los hijos cobren el seguro de vida. A diferencia de su hermano menor Jaime que rezuma virilidad por todos los poros, José-María es "pálido, aguileño, de piel marfilina y ojos verdes", de "belleza tímida y frágil, de flor", y le fascinan la pulcritud y las tareas del hogar, a lo que se suma que siempre está en compañía de sus hermanas y fantaseando sobre cosas de mujeres.

El autor se refiere a José-María en un pasaje como si se tratara de una muchacha. Cuando regresan del entierro del padre, José-María toma las riendas de la casa y lo 
primero que decide es que hay que dar un baldeo a la casa, pues hace falta "limpiar esto como Dios manda. ¡Da asco!”, luego de cuatro horas y cuando todo queda impoluto el narrador refiere como "ella, con las arañas de sus manitas tejedoras de orden, dirigía, por primera vez, del todo el hogar" (Énfasis añadido, El ángel de Sodoma 6).

José-María intenta luchar contra su inclinación homosexual, "flor pestífera" que para él mismo era una aberración: "un hombre renegado de su sexo, vilipendiándolo con el anhelo de cada uno de sus poros, con la feminidad de sus entrañas, era odioso, repugnante" (El ángel de Sodoma 26). Trata de endurecer el cuerpo con "media hora de gimnasia todas las mañanas" y hacía lo imposible por aplicar los estereotipos del heterosexual a su deseo. Comienza a fumar y a beber, todas actividades para la época que eran privilegio masculino, pero todo es inútil para ese joven "con cutis de jazmín” (21). Llega a la osadía de ir a un prostíbulo para "antes de desesperarse, correr la prueba última. Tal vez al contacto de la mujer la mala inclinación cediese, y triunfara para siempre en él el hombre", pero dicho intento fue un total fracaso, al quedar "helado de repugnancia por el beso húmedo y penetrante con que la hembra quiso sellar petición y promesa" (28).

A pesar de sus esfuerzos, José-María no puede dejar de pertenecer en espíritu y deseo a lo que el narrador llama "la funesta secta de las víctimas del error de Dios", y se dirige a París, en donde su anonimato sería seguro. A lo mejor allí podría darle curso a los deseos también de su cuerpo, pero es imposible y finalmente, a punto de darle satisfacción a sus apetitos por siempre reprimidos, se lanza debajo de un tren en lo que hace aparecer como un accidente. 
Montenegro. En 1938 se publica en México la novela Hombres sin mujer, de Carlos Montenegro, escritor cubano nacido en Galicia, España, en 1900 y venido a Cuba en 1907. Montenegro estuvo preso por doce años, de 1919 a 1931, cumpliendo una condena por asesinato. En su estancia en prisión comienza a escribir, y envía sus cuentos a concursos y revistas cubanas. Una vez que su fama de escritor se hace manifiesta le reducen la pena gracias a gestiones realizadas por influyentes intelectuales (entre ellos Enrique José Varona) que se unieron para pedir el indulto.

La novela, que había sido publicada por entregas en revistas nacionales de la isla, nunca vio sin embargo la luz como libro, pues como refiere Emilio Bejel, "fue recibida de manera negativa. . . debido mayormente a consideraciones morales. ... De hecho, no sería exagerado decir que Hombres sin mujer fue un escándalo en Cuba aun antes de publicarse como libro" ("Sexualidad carcelaria" 273). Como se puede apreciar, la suerte de Hombres sin mujer corrió paralela a la previamente mencionada El ángel de Sodoma. Aquella recibió el bautismo literario en suelo cubano en 2000, aventajando a El ángel por solo nueve años.

La desventaja de Montenegro en comparación con Hernández Catá es que mientras el velo de silencio que cubrió a Catá fue parcial, a Montenegro se le mantuvo completamente olvidado en la isla durante cuatro décadas de gobierno "revolucionario". Tal y como confiesa el autor en el prólogo en su obra se denuncia la homosexualidad que se da en las cárceles como consecuencia de la falta de la mujeres. Esto causó una gran conmoción en la escena literaria de la isla. Hombres sin mujer no ha dejado de trasmitir "sus pulsiones por medio de arquetipos socioculturales"-apunta Alberto Garrandés"que se refieren no solo al sexo, la sexualidad y los roles de género, sino también al 
sentimiento amoroso, al deseo, y al estatuto de la compañía y su nexo con el erotismo" (“Su majestad Carlos Montenegro”).

Lezama. No es hasta Paradiso cuando el tema de la homosexualidad alcanza dimensión de arte reflexivo y hasta que en los noventa el grupo de novísimos escritores la reivindica. Paradiso contiene unas de las escenas eróticas homosexuales más explícitas que se han publicado en español. Por ello, el régimen detuvo su publicación y quitó los ejemplares de las librerías cubanas. En el Capítulo 8 de Paradiso Lezama asume y resuelve el desafío del drama homoerótico de una manera descarnada y con un alto valor estético, a través de su inimitable lenguaje barroco:

Antes de penetrar Farraluque en el cuadro gozoso, observó que al rotar Adolfito, ya es hora que le demos su nombre, mostró el falo escondido entre las dos piernas, quedándole una pilosa concavidad, tensa por la presión ejercida por el falo en su escondite. Al empezar el encuentro, Adolfito rotaba con increíble sagacidad, pues cuando Farraluque buscaba apuntalarlo, hurtaba la gruta de la serpiente, y cuando con su aguijón se empeñaba en sacar el del otro de su escondite, rotaba de nuevo, prometiéndole más remansada bahía a su espolón. . . . La búsqueda de una bahía enloquecía a Farraluque, hasta que al fin el licor, en la parábola de su hombría, saltó sobre el pecho del miquito deleitoso, rotando este al instante, como un bailarín prodigioso, y mostrando, al final del combate, su espalda y sus piernas de nuevo diabólicamente abiertas, mientras, rotando de nuevo, friccionaba con las sábanas su pecho inundado de una savia sin finalidad. (269-70) 
Piñera. Otro de los casos de un intelectual vilipendiado y reivindicado es el de Virgilio Piñera. Dramaturgo, poeta y traductor matancero, como la inmensa mayoría de los cubanos de aquel entonces "le dieron la bienvenida a la Revolución cubana de 1959. La dictadura de Batista—recuerda Santí- había sido tan destructiva, su corrupción y crueldad tan totales, que cualquier cambio político se percibía para bien” (239). Piñera, ya en un ensayo aparecido en 1955 en la revista Ciclón, a raíz de la publicación de una edición de la obra poética de Ballagas declara en su ensayo sobre Ballagas, "y acaso por primera vez en la historia literaria de Cuba: las tensiones de la vida bisexual, lo que el propio Ballagas llamaba 'mi angustia desdoblada"' (Santí 238). En una sociedad tradicional como la cubana, en la que un hombre es un destino, un provinciano pobre y desconocido prácticamente no existía; y en esa misma cultura machista, donde la autorrepresión hacía que hasta homosexuales (como el propio Lezama) asumieran una postura homófoba, otro homosexual como Piñera, podía ser rechazado hasta por sus congéneres (Santí 234).

Arenas. En los setenta, el oficialismo entabló una cruzada homofóbica, acentuado por el sobrado canon nacionalista. Varios de nuestros más representativos escritores, entre ellos Reinaldo Arenas, fueron víctimas de esos extremos: "Ahora oigo como murmullan en la cocina. Hablan. Hablan. Hablan: están buscando la forma de matarte. Están buscando la forma de matarte.... Si yo pudiera hablarte te diría algo, aunque no sé lo que te diría, pero no puedo: me han cosido la boca con un alambre de púas y una bruja me acompaña siempre con un garrote" (Celestino 58-9).

Reinaldo Arenas es uno de los muchos autores que reaccionaron contra la degeneración nacionalista. Nacido en Aguas Claras (en la parte norte de la provincia de 
Oriente), su adolescencia campesina y precoz se vio marcada por el manifiesto enfrentamiento contra la dictadura de Batista. Colaboró con la Revolución cubana, hasta que, debido a la exclusión a que fue sometido, optó por la disidencia. Su presencia pública e intelectual le granjeó contrastadas aversiones en las más altas instancias del Estado, lo cual, unido a su homosexualidad, provocó una implacable y manifiesta persecución en su contra. Arenas solo pudo publicar un libro en Cuba: Celestino antes del alba, que obtuvo primera mención en el concurso nacional de novela de 1965.

En el caso de Reinaldo Arenas, su literatura no fue tratada como "democrática". Por el contrario, sufrió persecución no solamente por una desinhibida homosexualidad, sino por su resuelta oposición al comunismo, elementos ambos que le cerraron cualquier posibilidad de desarrollo como escritor e intelectual durante los años de mayor ostracismo cultural en la isla (Matías, El desengaño de Reinaldo Arenas 194).

En su autobiografía, Antes que anochezca, criticará como se acusó de traidor a todo aquél que se atreviese a discrepar: "agente de la CIA era la etiqueta que le pegaban, desde entonces, a cualquiera que disentía del régimen de Fidel Castro" (93), y explica como se limitó la libertad de prensa: "los libros que pudieron ser tachados de "diversionismo ideológico" desaparecieron de inmediato" $(100)^{33}$. Esgrime la homosexualidad personal para afianzar la disidencia política y atacar la opresión del poder, y reivindicar la libre elección y la humanidad como condición indispensable. Su

\footnotetext{
${ }^{33}$ Como "diversionismo ideológico" se define cualquier acción, concepto, idea, conversación o publicación considerada por el gobierno capaz de 'confundir' a la población y de 'servir' y 'hacerle el juego' a los intereses del 'enemigo'. Por lo general ese enemigo es el 'imperialismo norteamericano'. Por consiguiente, cualquier acto (o aún sospecha) de esas características debe ser reprimido y castigado. Véase "Diccionario del castrismo cotidiano".
} 
relegación al ostracismo, prisión en El morro, exilio y suicidio, hacen de Arenas un escritor enfrentado a su propio infierno personal, rebelde y colérico.

Querido:

Detrás de todas las fiestas públicas. Detrás de todo desfile, himnos, despliegue de banderas y elogios. Detrás de toda ceremonia oficial, se esconde la intención de estimular tu coeficiente intelectual y explotarte.

Esto me lo dijo Carlos Marx, haciendo un gracioso giro, soltando una carcajada y marchándose apresurado tras los fondillos de los niñosmilitares que integraban la retaguardia. (Arenas 33)

Las represalias contra Arenas se manifiestan también en la crítica que los voceros simpatizantes del régimen hacen hacia su obra. Por ejemplo, la ensayista Marilyn Bobes cataloga el homosexualismo del autor en antidemocrático y político: "Tal es el lamentable caso de un escritor como Reinaldo Arenas, quién convierte su testimonio Antes que anochezca en un alegato político donde la relación erótica se banaliza y se reduce a una suerte de persecución del placer cruelmente castigada por las instituciones y que parece, en sus historias, socialmente aceptada y permitida por los miembros de la comunidad" (Bobes, "El homosexualismo").

Paz. El escritor y guionista Senel Paz, pone definitivamente el dedo en la llaga con la inaudita e improbable amistad entre un comunista y un homosexual en la Cuba revolucionaria de finales de los años $60 .^{34}$

\footnotetext{
34 El cuento "El lobo, el bosque y el hombre nuevo", fue publicado en 1990 y adaptado a la pantalla grande bajo el nombre de Fresa y chocolate por el cineasta Tomás Gutiérrez Alea tres años después.
} 
David y Diego son personajes contrarios, patrones antagónicos. Diego es admirador de Lezama Lima, modelo literario contestatario y homosexual declarado, y propugna que el arte no debe tener una función política. Por el contrario David promulga la idea oficialista del arte subordinado al enfoque marxista de la lucha de clases. David propone como buen comunista la igualdad y la sobriedad; Diego, quien para David es en un principio un personaje decadente, disfruta la literatura elitista y lo extravagante. Heterosexual versus homosexual, futuro contra decadencia, fuerza y debilidad.

Diego es un practicante católico, otro aspecto que iba en contra de los principios de la Revolución, pues hasta principios de los noventa, tanto el catolicismo como la santería eran incompatibles con la política oficial. Diego, gran conocedor de la cultura cubana prerrevolucionaria, es el portador del saber cultural que fue eliminado y tildado como decadencia burguesa por el nuevo régimen. David, educado en el socialismo, es sin embargo un desconocedor de la tradición cultural cubana. Son las aspiraciones literarias de David las que facilitan que el versado Diego se convierta en su tutor particular, no sin especificarle abiertamente su condición de homosexual:

Antes voy a precisarte algunas cuestiones porque no quiero que luego vayas a decir que no fui claro. Eres de esas personas cuya ingenuidad resulta peligrosa. Yo, uno: soy maricón. Dos: soy religioso. Tres: he tenido problemas con el sistema; ellos piensan que no hay lugar para mí en este país. Pero de eso, nada, yo nací aquí; soy, antes que todo, patriota y lezamiano, y de aquí no me voy ni aunque me peguen candela por el culo. Cuatro: estuve preso cuando lo de la UMAP. Y cinco: los vecinos me vigilan, se fijan en todo el que me visita. 
¿Insistes en ir? "Sín", dijo el hijo de los campesinos paupérrimos, con una voz ronca que yo apenas reconocí. (cit. en Dettman 16)

El final de Diego, no por previsible menos doloroso, es que tiene que abandonar la isla donde nació. Su condición de cuerpo "extraño" y nocivo para la nación requiere que sea extirpado de ella.

Por fin con los noventa, y en medio de tantos cambios políticos, económicos, sociales y de todo tipo, llegan también "vientos de cambio" para el modelo hegemónico masculino, heterosexual y homofóbico.

IV. 1 Posnacionalismo y el destape del homoerotismo. ¿Una nueva incorporación al canon?

Razas, lenguas, historia, religiones, todo eso son vestiduras de quitaipón, debajo de las cuales surge, envolviéndolas y dominándolas, la esencial e invariable naturaleza humana.

José Martí (Obras completas 10:475)

Avec la révolution cubaine, un système de contrôle hégémonique s'instaure en soulevant l'homogénéisation de l'exercice de l'individualité. Malgré cela, les pratiques sexuelles alternatives ne sont pas arrêtées de se manifester dans la société cubaine.

Néanmoins, elles ont continué à être condamnées à l'ostracisme du silence. Patricia Valladares Ruiz

La ficción es la realidad de la que se nutren los sueños. No hay que insistir en la importancia de la ficción para coincidir con Volpi en que "escribimos cuentos y novelas no solo porque no podemos dejar de hacerlo, no solo porque nos hagan disfrutar con la perfección de sus frases o la fuerza de sus historias, sino porque los cuentos y las novelas nos han hecho quienes somos" ("Yo soy una novela" 54). 
La literatura se degrada cuando persigue una finalidad politizada, toma partido o esgrime criterios totalitarios, ideologías o banderas. Como nos expone Hannah Arendt: "la guerra y la revolución constituyen aún los dos temas políticos principales de nuestro tiempo. Ambas han sobrevivido a todas sus justificaciones ideológicas. En una constelación que plantea la amenaza de una aniquilación total mediante la guerra frente a la esperanza de una emancipación de toda la humanidad mediante la revolución" (Énfasis añadido, Sobre la revolución 3). De ahí se entiende esa permanente posición del oficialismo que continúa imponiendo el canon nacionalista a partir de una idea ya caduca del concepto de Revolución. Sin embargo, nuevas escritoras y escritores llevan algún tiempo cuestionando el macizo sujeto: “el desmembramiento del sujeto-nación les permite no solamente tematizar la diáspora cubana afuera de la Isla, sino también las diásporas contenidas en las diferentes identidades que emergen en la crisis del sujeto nacional" (Énfasis añadido, Lidia Santos 195).

Es necesario resaltar que existen pocos estudios críticos sobre el homoerotismo en la literatura cubana. Polemizar sobre la diversidad sexual es difícil, y no siempre puede achacarse a cuestiones morales o evasión de la crítica. El metarrelato de la "nación", históricamente impregnado de la perspectiva hegemónica de la literatura canónica heterónoma, ha calado profundamente en el imaginario popular.

Este fenómeno se exacerba a partir de 1959. Conjuntamente con la manida condición de "revolucionario" que se le exige a cada ciudadano Suquet Martínez plantea que "el discurso revolucionario, expresado como una batalla interminable en que numerosas circunstancias de disímil génesis son referidas en términos bélicos, ... reafirmó, aun sin pretenderlo, una axiología homofóbica", lo que se expresa en la 
homogeneización "que descansa sobre los rasgos emblemáticos de la masculinidad” ("La hamaca o el tajo" 49). De ahí se entiende el uso de términos que presentan al pueblo como una masa compacta, indistinta y sobre todo como "actor masculino": "el pueblo uniformado", el "pueblo viril", "el pueblo unido", "el pueblo combatiente". El agotamiento de un mismo discurso totalizador y perenne, cada vez más vacío de referentes, ha desatado la necesidad la búsqueda de nuevas formas de entender esas pequeñas minorías, esas pequeñas y necesarias "diásporas" que conforman las diferentes y diferidas identidades, entre ellas las relacionadas con la sexualidad y el erotismo.

La cultura nacional cubana, como consecuencia inevitable del contacto con el exterior que comienza a partir de los noventa, ha experimentado un rico proceso marcado por el tanteo formal y la ascensión de corrientes de pensamiento y arte contemporáneos, en cuya dinámica prevalecen revistas literarias y culturales. Se abre así el diapasón de ideas y de temas poco explorados hasta entonces, por desconocidos o por susceptibles de censuras. Se intenta seguir en este trabajo la sugerencia propuesta por Patricia Valladares Ruiz cuando plantea que "el hecho de que en Cuba las identidades sexuales alternativas estén constreñidas a construirse a partir de la teleología revolucionaria impone la reconsideración de coyunturas sociales, políticas y económicas que surgen con el advenimiento de la Revolución" (69).

Los escritores cubanos actuales que han abordado en sus obras los temas de las relaciones íntimas y sexuales, específicamente de orientación homosexual, se han adentrado en un terreno poco transitado, plagado de prejuicios y anacronismos. El sentido emancipador de la escritura que tiene como centro estos temas, hay que entenderlo a partir de la tradición de (y contra) la que se deriva, de los avatares que la 
han excluido, así como también de la historia de su reafirmación (Fowler, La maldición 8). Proceso emancipador en el que el concepto tradicional de "nación cubana" se niega, se difumina y se dinamita desde adentro para demostrar, en palabras de Bhabha, que:

"The 'other' is never outside or beyond us, it emerges forcefully, within cultural discourse, when we think we speak most intimately and indigenoulsy 'between ourselves"” (cit. en Valladares Ruiz 73). Eso es aún más cierto en el caso de los estudios sobre el homoerotismo femenino. Lacarra Lanz nos advierte que "la falta de testimonios documentales concretos sobre la homosexualidad femenina puede llevar al estudioso a recrear en los textos literarios un discurso poco afortunado, tergiversado o no siempre pensado, escrito o pretendido por el autor, sea este masculino o femenino" (12).

IV. 2. ¿Quiénes somos? La educación sexual bajo control

Puede parecer que el fenómeno de la aceptación y el apoyo a la publicación y circulación de literatura homoerótica sea una manifestación de que en Cuba actualmente se lucha contra la discriminación por la orientación sexual. Entre las corrientes influyentes a nivel global o de signo occidental, está la tendencia en las sociedades de Europa y de Norteamérica hacia una aceptación y legalización de las relaciones homosexuales y su integración definitiva en el sistema de derecho de esos países. Esta vertiente del desarrollo de la sociedad en los Estados occidentales colocó mas a la defensiva al modelo socialista cubano con su históricamente precario récord de cuestionable y fallido tratamiento de los asuntos homosexuales, razón por la cual el oficialismo cubano ha optado por tomar el rumbo de las políticas de máximo efecto 
propagandístico y a su vez con mínimos costos políticos (tales como el subsidio de las operaciones de cambio de sexo).

El límite del compromiso castrista continúa siendo la representación política organizada. En ese sentido, el régimen ha sido previsor. En 1989 se crea el CENESEX (Centro Nacional de Educación Sexual), con la misión de "gestionar la aplicación de la política cubana de educación sexual al coordinar la participación de entidades y organismos que se encargan de la comunicación social, el trabajo comunitario, la educación, la orientación y la terapia sexual” "“Quiénes somos”, CENESEX). De esta manera, la retórica oficial canaliza y controla, desde el Estado, un aspecto más de la identidad individual, en este caso la relacionada con la sexualidad. ${ }^{35}$

Cierto es que dicha institución se presenta como protector de los derechos sexuales de los individuos. No obstante, si se echa una mirada a las actividades fundamentales que desarrolla, no escapa que las acciones que lleva a cabo muestran otra faceta más de lo que podríamos llamar "el arte de gobernar" del castrismo. Es decir, el arte de imponer las ideas y decisiones desde el poder, y hacerlas parecer como decisiones colectivas. Este mecanismo para el control de la sexualidad, pariente "light" de las infames Unidades de Apoyo a la Producción (UMAP), no es algo excepcional, sino cotidiano en la vida de la isla. El CENESEX es una forma más de intervenir férrea y activamente en la vida privada del ciudadano. Es tal la prioridad que se le asigna a las cuestiones relacionadas con la sexualidad que quien dirige esta institución es Mariela

\footnotetext{
35 Entre las tareas del CENESEX están las siguientes: Proponer, asesorar y coordinar la política cubana de educación y salud sexual; Dirigir la Comisión Nacional de Atención a Personas Transexuales; Diseñar e implementar productos audiovisuales y editoriales informativos y comunicacionales; Diseñar, implementar y evaluar a nivel nacional e internacional, programas académicos de formación ("Quiénes somos", CENESEX).
} 
Castro, hija del presidente Raúl Castro. Así se pretende enviar el mensaje a los homosexuales de la seriedad de las intenciones por parte del gobierno cuando el presidente delega en su hija semejante responsabilidad.

A partir del triunfo de la Revolución, la homosexualidad fue considerada y tratada como parte y consecuencia de la corrupción del antiguo régimen, muy peligrosa para el proyecto comunista oficial. En 1965, el mismo año en que se ponen en funcionamiento las UMAP, respondía Fidel Castro de esta manera a un periodista extranjero acerca del tratamiento hacia los homosexuales: "Diré que los homosexuales no deberían ser admitidos en posiciones en las que puedan ejercer su influencia sobre la gente joven. En las condiciones bajo las que vivimos, debido a los problemas que enfrenta nuestro país, debemos inculcar en nuestros jóvenes el espíritu de la disciplina, la lucha, el trabajo. ... Esta actitud tal vez no sea la más correcta, pero es lo que sentimos" (cit. en Lockwood 107).

Los detentores del poder en la sociedad cubana procuraron eliminar o reprimir la manifestación de todo aquello que se consideraba "diferente" o "raro". Sin embargo, a partir de los ochenta el tratamiento hacia esas supuestas desviaciones comienza a cambiar, "reivindicándose como emblema de la cultura cubana a figuras como Lezama y Sarduy” (I. Álvarez 32). La retórica patriarcal, masculina y homofóbica que había dominado el imaginario nacional desde su formación, se empieza a llenar de agujeros. ¿Por qué el imaginario nacional todavía se concibe solamente desde la óptica de la Revolución? Quizás la respuesta más acertada la encontremos en Paul Lidsky cuando asevera que "el soplo lírico o épico y el entusiasmo se prestan a un fresco revolucionario, difícilmente a una obra contrarrevolucionaria" (99). 
En las dos últimas décadas las cosas en este aspecto han cambiado hacia la aceptación de las nuevas formas reivindicativas sexuales. Al retomarse el turismo como principal fuente de ingresos, no queda otra alternativa que echar mano de los viejos mitos tradicionales, a tenor del imaginario nacional: "la mulata de libido voluptuosa y la isla donde toda desinhibición es posible" (Pérez Inmaculada 33).

\section{3. Homoerotismo en la pantalla grande}

En la Cuba de hoy la subjetividad homosexual ha pasado de ansia de expresión a medio de supervivencia. Dos buenos ejemplos de lo anterior los podemos ver en una de las historias de la película documental Suite Habana del realizador cubano Fernando Pérez, y en la recién estrenada cinta en el 2014, La partida, coproducción hispanocubana dirigida por el cordobés Antonio Hens. ${ }^{36}$

En la primera cinta se cuenta la historia de Iván Carbonell, hombre casado, trabajador diurno en un hospital habanero. El plato de comida se coloca en la mesa porque su trabajo a tiempo parcial como travesti en un show, es el que le aporta el dinero mínimo para sobrellevar su vida. El sueño de Iván es que lo contraten para un gran espectáculo, y no otra que su esposa es quien lo prepara cada noche a transformarse como transgénico. El público aplaude y se excita con las bailadoras exóticas mientras las olas arremeten contra el Malecón en desesperado intento transformador. El segundo filme ha sido estrenado en los Estados Unidos, Alemania y España y Cuba. Aborda el

\footnotetext{
${ }^{36}$ Suite Habana obtuvo el Premio Coral del Festival del Nuevo Cine Latinoamericano (2003), evento que se celebra en La Habana anualmente. La cinta es un documental que sigue la vida de varias familias habaneras en un día típico. No hay diálogos, solo imágenes y sonidos. El sueño de Iván Carbonell, uno de los protagonistas es "actuar en un gran escenario".
} 
tema de la prostitución y el turismo sexual en la Cuba de hoy. La diferencia con otras cintas del mismo tópico es que ahora la historia no es la ya típica de la prostituta (conocida vulgarmente como "jinetera") sino de su variante masculina: el "pinguero".

Reinier y Yosvani son dos jóvenes amigos y practicantes aficionados de fútbol. Reinier es casado y tiene un niño pequeño, y Yosvani vive con su novia. Reinier, con el conocimiento y la anuencia de su esposa y de su suegra, se dedica a intercambiar sexo por dinero con hombres extranjeros homosexuales, para ganarse la vida y a la vez intentar de esa manera conseguir una vía para irse del país. Cuando avanza el filme vemos como se desata entre los dos amigos una delirante historia de amor y pasión mutua, y somos testigos de escenas homoeróticas ricas en detalles explícitos. Sin embargo, esto no estorbó el rodaje, la producción y hasta la compra de los derechos de distribución en la isla: "Tuvimos que convencerles [a los funcionarios del ICAIC] de que no era una película contrarrevolucionaria. Una vez convencidos de ello, todo lo contrario, he tenido más facilidades en Cuba que en España”, aseguró el director (Hens).

El ensayista Emmanuel Tornés Reyes conecta a la crisis de los noventa con este cambio de actitud cuando expone: "la crisis [se refiere a la época que comienza con el llamado "Período especial" nos condujo a un estadio de superior madurez, coadyuvó a que la cultura, incluida la cultura social, fuese más democrática, giro notable, por ejemplo, en la comprensión de la existencia de lo diverso, la permisión de la visibilidad de inquietudes de las parejas de otras identidades sexuales y su personificación en la literatura" (17). 
IV. 4. Nosotras (muchos más que) dos

A finales del 2012, un libro inunda el quehacer nacional como rara joya en la literatura de la isla, aunque no era ya el primer caso, como se verá más adelante. La Editorial de la Mujer nos trae de la mano de Julio César González Pagés Por andar vestida de hombre, una reconstrucción sobre la historia real de la mujer suiza Enriqueta Favez que visitó doce países, estudió medicina en La Sorbona de París y ejerció como cirujano en la Cuba de principios del XIX.

Denunciada y denigrada, fue juzgada y puesta en la cárcel y finalmente deportada de Cuba. Pero la historia de Favez, según declaraciones de González Pagés, no es tan importante por su condición de transgénico, su carrera o su matrimonio lésbico sino por el atrevimiento de aquella a transgredir fronteras infranqueables para su tiempo. Por los motivos de impía conducta fue condenada a pasar cuatro años prestando servicios en el hospital de Paula, en La Habana (González Pagés 85).

Ya la vida de esta doctora suiza tan vilipendiada y expulsada de Cuba había sido recogida en otros estudios, además de novelada por Benito Pérez Rojo en Mujer en traje de batalla, publicada por Alfaguara en 2001. Camayd-Freixas considera justo "resaltar la ‘cierta manera', el arte de Antonio Benítez Rojo, la maestría y sensibilidad con que le devuelve a Enriqueta Faber su rostro humano" (226). El libro de Benítez Rojo no parece que haya ni sido mencionado en Cuba.

Un año antes había salido en La Habana la primera antología homoerótica femenina en la historia de Cuba: Nosotras dos, libro que recibe las mejores críticas y alcanza récord de ventas en el país. Expone Rodríguez Sosa que Nosotras dos es un libro privilegiado. La editora, Dulce María Sotolongo Carrington propone la primera selección 
que en el panorama editorial cubano de hoy, reproduce relatos que cuentan sobre el amor o la relación íntima más allá del sexo, entre mujeres.

El periodista Félix García entrevistó a la compiladora y editora del libro para el periódico Tribuna de La Habana. Sotolongo Carrington expresó: "En ella traté de incluir a escritores cubanos, y a una buena cantidad de gente, en la batalla que libra el país contra todo tipo de discriminación, exclusión y homofobia” (cit. en García 13). Al permitir la publicación y el compendio de todo un volumen con un tema tabú antes apenas publicitado, los severos censores hasta incluyen relatos de escritores cubanos en la diáspora.

De los 50 relatos que componen el volumen, 32 corresponden a mujeres y el resto a hombres. En la colección hay por lo menos tres autores cuya residencia está fuera de Cuba: Mayra Montero, Achy Obejas y Sonia Rivera-Valdés. La primera reside en Puerto Rico y las otras dos en los Estados Unidos. Cuentos actuales, localizados todos en ambientes urbanos, la referencia directa a Cuba, y en este caso específicamente a la ciudad de La Habana, se puede detectar en alrededor de cinco cuentos. En los otros se puede inferir pero no queda claro, aunque sí el ambiente urbano de la narración. El ambiente universitario es frecuentemente encontrado en las historias.

En cuanto a la temáticas son variadas, entre ellas están: la insinuación del deseo homoerótico, el homosexualismo reprimido, el amor homosexual, la infidelidad a la pareja heterosexual, la experiencia lésbica en la adolescencia, la infidelidad imaginaba, el suicidio, las experiencias homosexuales femeninas en las becas, las relaciones de mujeres más maduras con jóvenes, el onanismo, la zoofilia, lo escatológico y el incesto. 
Sin entrar en apreciaciones subjetivas con relación a la calidad literaria que puedan tener las reivindicaciones de González Pagés en su novela Por andar vestida de hombre o las 50 historias recogidas en la antología homoerótica Nosotras dos, el solo hecho de su publicación y recepción favorable en la isla es un elemento positivo en sí mismo, que no se debe menospreciar. Además, es una señal del agotamiento de temas revolucionarios.

No obstante, este atrevimiento hacia una subjetividad homosexual literaria, y que de seguro también tiene su correlato social en la Cuba de hoy, no debe crear falsas expectativas más allá del propio hecho cultural. Rafael Rojas en Cultura e ideología en el comunismo cubano advierte: "En La Habana de hoy, por ejemplo, se puede ser católico, judío, santero, o protestante; rockero, jazzista, salsista o rapero; nihilista, liberal, conservador o marxista [y "jinetera", "pinguero", gay o transexual—se podría agregar], siempre y cuando no se sea públicamente opositor o disidente" (165).

Es decir, la condición sexual en sí del individuo no es todo el problema, sino también se valora su proyección o militancia política. Aún en los años de mayor represión sexual en Cuba, a finales de los sesenta y principios de la década siguiente, el castigo no era indiscriminado. Las UMAP, la parametrización, ${ }^{37}$ las pateaduras, los juicios por "escándalo público" y la pérdida del puesto de trabajo no se aplicaban a todos los homosexuales por igual. La "reeducación" podía tocarle a uno en suerte o no. Anna

\footnotetext{
${ }^{37}$ La parametrización (también llamado parametraje o parametración) es un neologismo surgido luego del Primer Congreso Nacional de Educación y Cultura y la creación del Consejo Nacional de Cultura en 1971. La parametrización establecía los "parámetros" de confiabilidad que tenían que cumplir los trabajadores de la educación y la cultura para continuar ejerciendo sus puestos. Como consecuencia de la aplicación de estas medidas muchos homosexuales fueron expulsados de sus puestos de trabajo. Para más información véase El martillo y el espejo: directrices de la política cultural cubana (1959-1976), de Emilio José Gallardo Saborido.
} 
Veltfort, alemana que vivió en Cuba esos años, y que por su condición homosexual fue pateada y golpeada y encima sometida a juicio, finalmente abandonando el país, hace una valoración esclarecedora:

Ocurría todo el tiempo que la sexualidad de las personas era pasada por alto. En un mundo pequeño, todo el mundo sabe quiénes son todos los demás. En un mundo pequeño el tabú es solamente una herramienta útil cuando resulta conveniente. Todos sabemos de líderes prominentes en el Instituto Cubano de Arte e Industria Cinematográficos que eran gays en esos días, ¿no? (Énfasis añadido, cit. en Martínez-San Miguel 190)

IV. 5. El régimen contraataca

La UNEAC es el Moncada de la cultura, y tenemos que ser consecuentes con ello. Miguel Barnet (VIII Congreso de la UNEAC. 2014)

Cómo era de esperarse, el oficialismo no se queda de brazos cruzados frente a la arremetida posnacional. La historia de Cuba ha demostrado una y otra vez que el Estado no tolera cómodamente la marginalidad, el nihilismo o el homoerotismo. Por más que pueda parecer que el régimen, al abrir las puertas a la inversión extranjera en los asuntos literarios, da razón suficiente para que una literatura de nuevo signo avance y se establezca, resulta bastante improbable. Algún que otro autor puede ser publicado tanto en el exterior como dentro del país y tener cifras de ventas sustanciales y ganar algún que otro premio, pero en el patio si no eres obediente y fiel de las normas oficiales y crees que puedes hacer "revolución literaria", las puertas se te cerrarán. 
Abel Prieto en entrevista concedida a Arturo García Hernández, y refiriéndose a los errores del denominado "quinquenio gris" ${ }^{38}$ que se mantienen en la actualidad, admite como uno de ellos la exclusión de los homosexuales, pues "venimos de una tradición machista muy fuerte. Cuando entré a la universidad, en el año 68, conocí gente muy honesta e intelectualmente con mucha preparación, pero que eran homófo[b]os" ("La política cultural de Cuba, sin dogmas ni sectarismos").

En fecha tan reciente como el 11 de abril de 2014 Miguel Barnet, en la inauguración del VIII Congreso de la UNEAC expresó: "El mercado no puede dictar la política cultural" (cit. en L. Pérez, "Miguel Barnet en inauguración del Congreso") ${ }^{39}$. En otro momento de su discurso, reiteró que los escritores y artistas en la UNEAC aspiraban a un pueblo culto y retomó las palabras de Fidel "la cultura es lo primero que hay que salvar", con lo cual queda despejada la duda, es decir, se continuará imprimiendo lo que esté avalado por la el oficialismo. Este escritor y político cubano obtuvo el premio Juan Rulfo en el año 2006 por su cuento "Fátima o el Parque de la Fraternidad", que paradójicamente nos lleva de la mano por la vida de un travesti. Expresamos paradoja porque la transgresión se encuentra indisolublemente ligada a la nueva ola homoerótica nacional, y corresponde como ninguna otra vertiente literaria, a la necesitada por el mercado, el mismo que dicta pautas y del que respondió la UNEAC en la voz de su presidente.

\footnotetext{
${ }^{38}$ Período de severa censura y represión entre los años 1971 y 1976, también conocido como el período estalinista.

${ }^{39}$ Miguel Barnet es el actual presidente de la UNEAC y miembro del Comité Central del Partido Comunista de Cuba. Es un escritor premiado y reconocido, con obras como Biografía de un cimarrón y Oficio de ángel.
} 
Esta es la misma UNEAC que vetó a Reinaldo Arenas, por citar un ejemplo. Barnet se refugia, hecho que se repite en todos los discursos, manifiestos y proclamas oficiales desde 1961, en que nos encontramos dentro de "un país acosado y bloqueado como Cuba; un privilegio en un planeta donde prevalece la rapiña, si bien, no ha sido un camino de rosas". Para el dirigente de la cultura cubana, las necesidades de revitalizar, transformar y reestructurar el canon no es más que encontrarnos ante "criterios economicistas" que deben ser resistidos en provecho de los valores espirituales del país, por tanto, "hay que sentar pautas de jerarquía en materia de literatura y arte". ... El mercado no puede invadir nuestro mercado porque es incompatible con la cultura, con la sociedad, con la naturaleza y acaba con el pensamiento. El mercado es el dinero y este la fuente de la corrupción y de la pobreza" (cit. en L. Pérez)

En el acto por el 55 aniversario de la entrada de Fidel a la Habana, efectuado el 10 de enero de 2014, el primer vicepresidente de Cuba Miguel Díaz-Canel Bermúdez dictó: "En nuestro caso, como sucede en varias regiones del mundo, se perciben intentos de introducir sutilmente plataformas de pensamiento neoliberal y de restauración del capitalismo neocolonial, enfiladas contra las esencias mismas de la Revolución Socialista" ("Nosotros continuaremos adelante"). No hay medios tonos ni grises, el oficialismo ha echado a andar su maquinaria represiva una vez más. En una clara alusión a los novísimos escritores posnacionales y otras artes, Díaz-Canel interviene para puntualizar cual debe ser el papel de las universidades y centros de investigación:

Productores de ideas y cultura, escenario por excelencia para discutir y reflexionar sobre los grandes problemas de la sociedad. Deben conceptualizar los procesos que vive la nación, en particular trabajar 
en la fundamentación teórica de nuestro modelo socioeconómico. Tienen un papel insustituible en la difusión de las ideas marxistas, leninistas y martianas, que no en balde son motivo de crítica y tergiversación permanentes por parte de los alabarderos de las peores causas. Debemos estimular el debate ideológico y la polémica, la capacidad de análisis crítico, comprometido y revolucionario, el conocimiento y respeto de la historia, que es la base de la cultura política del ciudadano. (Énfasis añadido, "Nosotros continuaremos adelante")

Nos encontramos en presencia de lo que en el argot popular se denomina "recoger pita". El binomio Estado/Nación establece la (in)creíble ilusión de apertura, recoge algo de dividendos y luego cierra las compuertas. Así ocurrió con muchas de las paladares (restaurantes privados de doce sillas), pequeñas salas de cines 3D y negocios de desodorantes y artículos de aseo; otros pequeños negocios de venta de ropa importada de Ecuador, etc. Todos eliminados virtual o completamente luego de algún tiempo de funcionamiento por supuestas violaciones. Puede que no pase mucho tiempo para ser testigos de ver como los escritores posnacionales sufren una suerte parecida.

\section{6. Conclusiones parciales}

Aprendí que era pobre, que era homosexual y que me gustaba el Arte. Virgilio Piñera ("La vida tal cual")

La crisis de identidad que ha vivido el mundo occidental a partir de la segunda mitad del siglo XX, como parte de la transformación "social más rápida, profunda y 
universal de la historia humana" (Hobsbawm, "Identidad" 16), unido al desmoronamiento de la última gran utopía del siglo: el socialismo, ha conllevado a la destrucción y evaporación de los vínculos tradicionales. Con la crisis de los años ochenta comienzan a ocupar los papeles protagónicos las historias marcadas por el desequilibrio y la ambigüedad. El machismo, las drogas, la prostitución, la intolerancia, la doble moral y el homosexualismo se destraban de la censura y se incorporan en el camino literario. El régimen admite y publica, pero no es un movimiento bien visto y menos apoyado.

Si se observan los textos que han tratado la subjetividad homosexual, se aprecia que durante largo tiempo estuvo ligada dicha problemática a la idea de lo sucio y lo impuro, relacionado con el pecado. El placer del sexo, y más si se trata del placer homoerótico, es visto como problema, en ocasiones como crimen y en otras como enfermedad. En la narrativa contemporánea dicha noción está siendo superada, y la inclinación homosexual se acepta como legítima.

(Re)construir el discurso nacional en la Cuba de hoy, resulta imprescindible para la cimentación de nuevos valores de identidad cultural. El homoerotismo se asume y se acepta en la isla como intento por revitalizar los atractivos de la propuesta socialista cubana, obligada en capitalizar el turismo y la inversión de capitales. El fenómeno del turismo sexual, encarnado por la "jinetera" primero y ahora acompañada por el "pinguero", se incorpora al nuevo concepto oficialista del imaginario nacional.

La literatura homoerótica como componente del canon posnacional ya cuenta con sus seguidores. Nos encontramos en presencia de un género que pugna por instituirse y trascender. Sin embargo, algunas obras desarrollan una transgresión tan brutal que provoca el alejamiento de un público harto de temas manidos y de historias marginales 
que al final se vuelven en contra de los propósitos que se desean alcanzar. Un ataque sin sentido no legitimiza la literatura que se desea sostener. Algunos estudios hechos en Cuba sobre los temas antes señalados no escapan a este lastre. Igualmente se debe tener en cuenta no tan solo las condiciones que antecedieron al surgimiento de la nueva tendencia posmoderna entre escritores novísimos, sino además, hacer mención del impacto de los nuevos conceptos de globalización, desterritorialización y deshistorización. Vale destacar, asimismo, la influencia de los medios audiovisuales en el canon actual, los cuales universalizan la cultura en general y la literatura en particular.

Existe, al margen del entorno tradicional cubano, un grupo de narradores con valores culturales, patrones estéticos e intereses relativamente globales. En un plano más abarcador, se perfila un público protagonista y a la vez destinatario de estas letras posnacionales, familiarizado con fenómenos económicos y expresiones culturales de Occidente: Cohabita el insípido producto de Nestlé con el aromático café local; la superproducción cinematográfica de Hollywood con el espartano cine nacional; el costoso video clip musical de una Beyoncé con una artesanal producción musical nativa. Los contornos literarios en la narrativa cubana posnacional actual propugnan, entre otros postulados, la reivindicación de la universalidad, el desentendimiento con relación a los destinos de la nación, y su vocación experimentalista. 


\title{
CAPÍTULO V
}

\section{ANNA LIDIA VEGA SEROVA ENTRE DOS AGUAS. EL DESARRAIGO Y LA IRREVERENCIA DE LA ESCRITURA}

\author{
De nuevo has vuelto a escribir poesías. \\ Esta vez con más furia que antes, ahora todo el barrio sabe quién eres. \\ Ya no tienes escapatorias. \\ Reinaldo Arenas (Celestino antes del alba) \\ But something is happening here \\ But you don't know what it is \\ Do you, Mister Jones? \\ Bob Dylan ("Ballad of a Thin Man")
}

Mixtura de los submundos marginales de igualdad y diferencias entre Cuba y Rusia, en Vega Serova confluyen lo que Hinkson denomina "teoría social de la posmodernidad" y que Appadurai explica como formas culturales fracturadas que se yuxtaponen de manera politética, es decir, carentes de regularidades, estructuras y fronteras (La modernidad 42-3).

Parecería que la influencia de las costumbres y la cultura rusas, tan ajenas al estilo e idiosincrasia cubanos se difuminó completamente después de 30 años de "hermandad" socialista. Sin embargo, ese período todavía marca la vida de la isla. Más aún de aquellos vinculados por lazos de sangre, como es el caso de la autora que ocupa la atención de este capítulo.

La cita a continuación vino a ser del conocimiento del autor de este trabajo cerca ya de la culminación del mismo, y se presenta muy bien para justificar la inclusión de Vega Serova entre las escritoras estudiadas en esta tesis. Forma parte de una entrevista realizada por la profesora de Letras Hispánicas de Davidson College Angela L. Willis a la escritora, durante la visita de aquella a la capital cubana en fecha tan reciente como 
junio de 2013, originalmente aparecida en la revista académica The Latin Americanist en diciembre de ese propio año. Dice así:

Anna Lidia Vega Serova, escritora prolífica ruso-cubana (nacida en Leningrado en 1968 de padre cubano y madre rusa); Anna Lidia Vega Serova, lesbiana y madre; Anna Lidia Vega Serova, ganadora de múltiples premios, tanto en Cuba como en Latinoamérica; Anna Lidia Vega Serova, una gran cuentista reconocida por una narrativa que evoca una juventud complicada, desdichada, y casi siempre solitaria que transcurre entre Rusia y La Habana donde predomina un ambiente crudo de drogas, infidelidades, y vidas rotas; Anna Lidia Vega Serova, quien ofrece esperanza a pesar de todas las adversidades que le han tocado vivir; Anna Lidia Vega Serova, desgraciadamente poco conocida por la Academia norteamericana. (Willis 131)

Vega Serova ha sido tildada, entre otras cosas, de novelista sucia, enajenada, hippie, lésbica, grotesca y sórdida. Sin embargo, críticos y lectores coinciden en que forma parte indispensable de una hornada de escritoras que - con un grumoso respaldo retórico - volcaron sobre la escena de la isla una perspectiva innovadora para la prosa escrita por manos femeninas en los finales del siglo XX y principios del XXI.

Valga como soporte a tal afirmación el hecho inusual de la reedición, en 2012, por Letras Cubanas, del título Ánima fatua. Inusual en el sentido de la prácticamente nula costumbre en Cuba de segundas ediciones, salvo las usuales excepciones de las obras consideradas canónicas por el aparato cultural. Este éxito fue reflejado en la prensa escrita por lo insólito y específico y por "su capacidad para ahondar en el drama de la 
identidad desde sus distintas facetas: las búsquedas del Yo (identidad personal), las exploraciones del Otro homoerótico (identidad sexual) y el drama de la transculturación (identidad nacional y cultural)" (Cubanow, "Isla de letras" 1).

La periodista Marta Rojas, quien ha gozado siempre del favor oficial por sus vínculos con el aparato cultural de la Revolución, por su parte ha usado una expresión concisa para describir a Vega Serova: Alma dividida. Con una singular voz femenina, Anna Lidia Vega Serova aporta a la literatura cubana contemporánea su peculiar visión de la convivencia ruso-cubana en su libro Ánima fatua. Convivencia, que conviene recordar, fue muy estrecha durante treinta años en lo militar, político, ideológico y económico en la isla, pero que asimismo (si bien a regañadientes) tuvo un impacto social.

En la novela, que recorre la niñez y juventud de un ser nacido de una madre rusa y un padre cubano en un drama de niñez, adolescencia y temprana juventud madura, y que transita por hechos y sensaciones morales filiales y sensuales, se mezcla el trágico peso secular de la tradición literaria rusa con el gracejo cubano. La prosa de Anna Lidia—nos dice M. Rojas—ofrece un contrapunteo lacerante que da cuenta de una identidad compartida, en la que afloran conflictos psicológicos, sociales y sexuales generados tanto por el amor como por el desarraigo. Narrada en primera y tercera personas indistintamente, el relato va a las profundidades de una dualidad tumultuosa. Vega Serova cautiva al lector por su aparentemente sencilla construcción literaria, indicadora de lo que de hermoso y mísero tiene un alma dividida ${ }^{40}$.

\footnotetext{
${ }^{40}$ Se calcula que a la caída del Muro de Berlín habían vivido en la isla (sin contar los asesores militares) cerca de 18.000 soviéticos, de los cuales una gran mayoría la abandonó tras el colapso socialista. Hoy se estima que viven, contando a sus descendientes, cerca de 6.000. Desde el mismo 1961 y hasta 1990 estudiaron en la antigua Unión Soviética (tanto técnicos medios como en estudios graduados y posgraduados) entre 100.000 y 300.000 jóvenes (Heredero).
} 
Hay que agregar que los métodos pedagógicos aplicados en Cuba a partir de principios de los setenta hasta principios de los noventa, fueron aquellos que venían del llamado campo socialista. Los libros de textos escolares en la educación primaria, secundaria y universitaria venían en su mayoría de estos países, incluyendo los manuales de filosofía marxista-leninista, de materialismo histórico y de materialismo dialéctico. El experimento solidario internacional comunista llegó a la aberración de imponer la enseñanza en los estudios secundarios y universitarios de asignaturas con títulos tan pretenciosos como "socialismo científico", y posteriormente, "comunismo científico".

Lo expuesto permite entender cómo una novela como Ánima fatua haya sido tan bien recibida por los lectores de la isla. El caso de Vega Serova corresponde bien a una generación específica de escritores nacidos con la Revolución bajo la duplicidad étnica de dos culturas - "agua tibia" o "polovinka", como se denominan comúnmente a los hijos de matrimonio ruso y cubano-y que con la conmoción de deambular en territorio de nadie, trajo el enriquecimiento posnacional a un sector que comenzaba a dar signos de agotamiento por su encasillamiento desacreditado en un discurso patriótico en degeneración. Otra escritora "agua tibia" que va labrándose en la isla un camino es Polina Martínez Shviétsova, ganadora del premio Iberoamericano de Cuento Julio Cortázar en 2009 con su narración "Skizein (Decálogo año cero)”.

Anna Lidia Vega Serova dirige la atención sobre el escenario desde lo femenino, evitando tanto los clichés nacionalistas como la abierta confrontación política. Su ficción realista formula los estragos de una generación que opone resistencia a la ya insoportable monotonía nacionalista oficial. Por otra parte, ella pertenece a un grupo selecto de 
creadores cubanos que también han desarrollado una obra pictórica. Como anota Luis Rafael:

Siguiendo la senda, entre pictórica y literaria, de los cubanos Amelia Peláez, Arístides Fernández, Víctor Manuel, Wilfredo Lam o Fayad Jamís, la Serova se debate entre la paleta de colores y el negro crecedor sobre la página blanca....

Fiodor Dostoievski, Antón Chejov, Boris Pasternak, Julio Cortázar y J.D. Salinger, iluminan su indagación del ser ante la crisis de valores, sus malabares eróticos y sus exploraciones socio-culturales". ("Las fronteras de Anna Lidia Vega Serova")

La obra de Anna Lidia Vega Serova es poseedora de una interesante y provocadora prosa, sus protagónicos están impresos de una compatibilidad fragmentada e irreconciliable. Escritora de la condición humana es, junto a prosistas de la talla de Marilyn Bobes, Wendy Guerra, Karla Suárez y Ena Lucía Portela, parte de la avanzada que clama por leer el interior del ser humano, sus conflictos, alegrías y sinsabores, en una sociedad escindida.

Se trata de una autora que tiene el poder para pregonar el cataclismo, no importa el camino que escoja — y son varios-para expresarse. Por ejemplo, puede destacarse desde su incursión en el realismo sucio con obras como Bad Paiting (Premio David, 1997), Catálogo de mascotas (1999) e Imperio doméstico (Premio Dador, 2005), cuyos contextos estéticos se encuentran marcado por una visión bufa y voyeurista de la realidad cubana, hasta su inusitado libro Mirada de reojo (2010), que se trata en más detalle luego. 
V. 1 Biografía. Obras. Reconocimientos

Serova nace en Rusia, de madre rusa y padre cubano. Con tres años, luego de la culminación de estudios del padre, va a Cuba donde permanece por un período de seis años. De vuelta a Rusia con nueve años, allí pasa el resto de su niñez y toda su adolescencia. Con diecinueve años regresa a la isla caribeña para conocer a una hermana y reencontrarse con su progenitor, justo en medio del derrumbe de la URSS y del paradigma socialista. Desde entonces reside de manera permanente en la isla. En una entrevista concedida a la periodista Helen Hernández en 2008, Vega Serova explica la dificultad que ha significado en su vida la doble condición de rusa y cubana. A la pregunta ¿Ser hija de rusa y cubano influyó en su identidad y en su manera de percibir el mundo?, responde:

Cuando empecé a escribir, para mí era una especie de escape de la realidad, estaba tratando de construir un mundo ficticio porque lo real me resultaba demasiado agresivo precisamente por esa doble nacionalidad. La palabra patria no tiene plural en ningún idioma. Sin embargo, en mi caso y en el de otros hijos de matrimonios mixtos, nos vemos en medio de un desarraigo tremendo porque no somos ni de aquí ni de allá.

Cuando yo estoy en Cuba, muchas personas me dicen la rusa y cuando estoy en Rusia me dicen la cubana. Es muy dificil encontrar un sitio propio. Yo traté de buscarlo de diferentes formas hasta que lo encontré, creo, en la literatura. A la hora de escribir, la doble nacionalidad también 
funciona como un catalizador para mis angustias. (Énfasis añadido, "La literatura es un juego")

Quizás la ambivalencia de dos mundos tan disímiles como cercanos y yuxtapuestos en un momento de la historia, descubre en la ágil y múltiple pluma de Serova la relación simbiótica entre arte y humanidad, cuando ensambla personajes de disímiles naturalezas, capas sociales, ideologías o nacionalidades. A veces nostálgica, a veces irónica, Serova nos lleva a un universo evasivo de personajes marginados y enajenados mediante el uso frecuente del narrador protagonista femenino, quien intenta sobrevivir a como dé lugar mediante gestos y puntos de vista apesadumbrados.

Anna Lidia Vega Serova es pintora, novelista, prolífica poeta y cuentista. Ha incursionado con éxito de crítica y público en Cuba y dirige una peña literaria en Alamar, un barrio en las afueras de La Habana. Fue galardonada por su cuaderno de cuentos Bad Painting con el Premio David (Ediciones Unión1997).

El desarraigo se encuentra presente en Noche de ronda (2001), finalista del premio Casa de las Américas para narrativa experimental, novela estrafalaria y burlesca llena de paisajes oníricos y guiños intertextuales. Novela juguetona, la narradora vuelve una y otra vez a las historias dándole siempre un enfoque diferente y cambiando el contenido, expresión de la imposibilidad de aprehender la realidad: “A decir verdad, no fue así como sucedió todo eso. Es muy difícil contar las cosas objetivamente, pero lo intentaré otra vez"; "Quiero aclararles que esa gente no dijeron nada de eso. Eso fue lo que pensaron decir. Pero en la vida real nadie dice lo que piensa decir, ni hace lo que dice pensar. Ni siquiera yo"; "Me imagino que ustedes se imaginan que nada de eso fue así. Les contaré la verdad verdadera de cómo fue" $(17,24,31)$. 
Novela con un vocabulario donde sobresale lo procaz, la protagonista se refocila igualmente en relaciones homoeróticas lésbicas como heterosexuales. La relación lésbica no se considera orgásmica mediante el sexo tradicional, sino mediante la búsqueda de soluciones más placenteras y creativas:

Bunny Banana se despertó con dolor en los huesos. Se pasó toda la noche templando con Mariluz, adoptando posiciones incómodas para mayor estrafalariamiento.... (¿Cuándo fue la última vez que templaste? ¿Cuál es tu promedio de orgasmos mensuales?) No es lo mismo templar con un tipo que con una tipa. Pero para la pobre Bunny que se iba a echar un perro, a falta de pan...”. (17)

Lo anterior contrasta con la manera en que se plasman las relaciones heterosexuales, las cuales aparecen plagadas de violencia, perversión y opresión. Un ejemplo de esto último se ve cuando la narradora se refiere a los años de matrimonio de Bunny Banana con Yoswasleydis Puñales en estos términos: "Cada uno respectivamente fue: máquina para lavar-planchar-cocinar-fregar-hacer el amor y máquina para exigir que se lave-planche-cocine-friegue-haga el amor. Máquinas fuertes y bien diseñadas. Anticorrosivas" (11). En Noche de ronda los protagónicos sustituyen el amor tradicional de la familia por madres que niegan el sacrificio y el amor. La condición lésbica no supone una controversia de mujer insatisfecha o transgredida, al contrario, las mujeres que practican la homosexualidad son retratadas como seres más completos y creativos.

Dentro de la cuentística se incluyen los volúmenes Bad Painting (1997) y Catálogo de Mascotas (1999), en los cuales Serova examina el tema homoerótico explícitamente en varios de sus cuentos, por ejemplo "La estola" y "En familia". En 
ambos, los encuentros lésbicos presentan deseos y exploraciones sexuales con derroche e irreverencia.

En "La estola" se atacan los patrones heterosexuales, representados como opresivos, y el deseo lésbico interviene como elemento desestabilizador. Un triángulo amoroso contado desde el punto de vista de cada uno de los tres participantes (un hombre casado que desea a la nueva ascensorista, mientras que esta se siente atraída por la esposa de aquel, Elsa). El protagonista masculino, de cuyo nombre solo conocemos sus iniciales J.M., y que se siente agobiado por la vida de familia tradicional: "Elsa me asfixia en esa obsesión suya con la fidelidad, las verdades y la seguridad doméstica", está deseoso por tener una aventura con la joven: "tengo ganas de enamorarme de una muchacha con ojos violetas, así, sin compromiso, sin obligaciones, sin esclavitud, sin convivencia. Llegar un día y decirle te amo y que pare de tejer y me sonría" (71-2). Esta actitud contrasta con la de joven ascensorista, la cual no tiene nombre propio en la historia y que es la figura desestabilizadora, a pesar de ella misma. En su imaginación fantasea con una relación con Elsa (esposa de J.M.) pero no solo desde la perspectiva de una aventura homoerótica pasajera sino desde una amorosa. El homoerotismo queda planteado como posibilidad, como deseo y sentimiento.

En el libro Limpiando ventanas y espejos de 2000 (y al cual se le dedica un aparte), Anna Lidia sobrepasa la ironía y el humor amargo de sus anteriores escritos para con maldad incisiva burlarse de todo. Muy destacable el cuento "Esperando a Elio", donde una mujer intenta suicidarse cuando encuentra una cana en su pubis.

En la cuentística seroviana siguen las colecciones Imperio doméstico (2004) y Legión de sombras miserables (2005). El día de cada día de 2006 es una colección de 
cuentos donde lo que prevalece es la reflexión sobre la soledad esencial del ser humano. En el primer cuento del volumen "La guardiana", la protagonista Sara repasa su vida en los últimos años, período en el cual todos sus amigos se han ido del país, siempre con la promesa de un pronto regreso y de mantener la comunicación, sin cumplir con ninguna de las dos. Sara se convierte en la depositaria de muchos objetos de los amigos que se marchan, y así intenta mantener viva en la memoria el recuerdo de ellos. Tiene, por otra parte, un sentido de culpa: "Se iban todos los que la rodeaban, todos los que de cierto modo había rozado, como si cargara con una maldición" (14). Al final un fuego destruye el apartamento, y con ello también los recuerdos y la poca esperanza que aún le quedaba para seguir viviendo.

La original estructura del libro incluye viñetas o intertextos intercalados entre cuento y cuento que narran aparentemente elementos autobiográficos de Vega Serova, entre ellos las reflexiones luego de una dolorosa ruptura de la autora con su novia. Aquí también el narrador insiste en lo frágil y poco convincente que pueden ser los recuerdos. Este es un extracto de una de dichas viñetas:

Mi ex novia y yo recordamos los inicios de nuestra relación. Es sorprendente la diferencia entre sus impresiones y las mías. La diferencia de la imagen que yo tengo de mí misma de aquella época y lo que para ella era yo...

Mi ex novia y yo recordamos los inicios nuestros.... Ahora que todo acabó, volvemos a ser atentas y cariñosas, como si nunca nos hubiéramos hecho daño, como si nunca nos hubiéramos traicionado. 
Mi ex novia y yo recordamos los inicios. Espérate, le digo, tienes un churre en el ojo....

Mi ex novia y yo recordamos. ... No nos besamos. Sabemos que un solo beso en estos casos puede ser fatal. ...

Mi ex novia y yo. Temblamos. Los sueños muriendo dentro nos hacen temblar. ... Eva Camila, nuestra bebé....

Mi ex novia. Su voz. Sus ojos. Su olor. ...

Siento bajo las costillas el cosquilleo de la libertad, como burbujas de champán. (83)

En el cuento "El día de cada día" que da título al volumen, aunque no hay mención directa, se detecta la realidad cubana a la que se refiere el texto: "no hay comida — no hay dinero—no hay ropa limpia —no hay detergente para lavar la sucia $—$ no hay jabón para bañarse — no hay champú—no hay pasta de dientes... "para qué quieres cepillarte los dientes si no hay comida? No hay dinero—no hay—no hay—no" (102), así también se nota una voluntad transgresora, sórdida y marginal en la escritura seroviana:

Mi amiga Beba tiene poca experiencia en el arte de vender el culo. Comienza con rodeos, no hay comida, dice, no hay dinero. Pupo mira sus ojos hermosos, Tato aspira su olor mágico aunque no hay jabón, no hay desodorante. Serás la reina de esta casa, lo tendrás todo.

Bien, dice ella, comienza. Él se saca la pinga, la babea abundantemente, la amasa ¿te la puedo echar arriba? Ella se 
desnuda, se quita la más limpia de sus ropas sucias, se toca, vamos, dice, qué rico. (104)

Esta autora tiene varios poemarios, entre los que se cuentan Eslabones de un tiempo muerto (2005), con creaciones elaboradas entre 2000 y 2004 y donde se aprecia el amargo sabor de la existencia a la vez que se toca el la subjetividad homosexual: "Todo el mundo quisiera / acostarse con mi novia, / sentarse en mi sillón a fumar / . . . Todo el mundo ignora que mi novia está obsesionada con los sombreros, . . . / que vivo en un hueco / profundo / profundo / profundo" (53).

En 2010, Serova publica Mirada de reojo, libro a medio camino entre la prosa poética y el cuento, y que por su talante podría ser confundido con un libro para niños, está compuesto por 50 textos, de ellos 42 con títulos y 8 viñetas o intertextos. Las narraciones, especie de mini cuentos poéticos con una extensión de entre una y tres cuartillas y casi siempre acompañado por un dibujo de la propia autora, dialogan con el lector mientras la autora realiza un inventario del apartamento. Cada historia lleva por título un objeto de la casa (la cama, la mesa, la silla, el televisor) sin que falte el inodoro: "Ha sido una ironía macabra que el recipiente que tanta mierda recoge lleve el nombre de inodoro, ¿no crees?” (Mirada de reojo 101), o un objeto significativo en su intrascendente supervivencia diaria (el cigarro, el reloj, el libro, el pincel).

La influencia de El principito de Saint Exupéry en la escritura de este volumen es palpable. Ese tándem entre supuesta tozudez e inocencia con que empieza: "Sé que mi misión es de una gran responsabilidad, aunque suene ridículo”, para luego crear un rapport cándido con el lector cuando lo convida a "mantener oculto todo respecto a nuestro contacto" e inmediatamente llamar a su conmiseración mediante una pueril 
excusa: "[q]uiero disculparme por mis torpes dibujos, la mala letra y las faltas de ortografía" (11) le debe mucho al escritor francés. Es también muy íntimo, muy cercano, y por supuesto muy individual: "necesito que tengas presenta que jamás, en ningún momento, escribiré en nombre de la Humanidad" (Énfasis añadido, 11). Pero al igual que El principito, este es un libro que trasciende el marco de la niñez o de la adolescencia y puede ser leído por los adultos con igual satisfacción.

Conviene transcribir íntegro uno de los mini cuentos cargado de poesía, sin título, en el cual se presta atención a la adhesión de esta autora por su arte (el de la literatura en este caso): "Escribo con lágrimas en las paredes y con saliva sobre mis muslos, en la nata oscura de la noche, en las telas de araña de la esquina, en las manchas de sol. Escribo, escribo, no tengo para cuándo acabar" (81).

Su lista está íntegramente conformada por objetos físicos que hallamos en una casa y lo que nos cuentan esos textos es su relación personal con esas cosas. Entreteje los textos de su memoria particular de objetos con unos intertextos, que en esta ocasión no aparecen en cursiva, sino por signos tipográficos que están carentes de presentación previa por parte de la autora, que ahora se ha desdoblado en Alia Pérez Petrova:

Presiento que no soy la única elegida de mi raza; así como yo, debe haber otras personas que retraten para ti y los tuyos los detalles de nuestra civilización a partir de las cosas que le rodean y que forman su mundo. Tal vez, sumando numerosos reportes, te lleves una idea más o menos completa de lo que hemos sido. (Mirada de reojo 12)

El uso de intertextos o viñetas, recurso que ya había utilizado en El día de cada día para hablarle directamente al lector, y que se diferenciaban por las cursivas y por 
mantener una especie de encadenamiento entre ellos, también se usa como recurso en este volumen, solo que ahora se intercalan esporádicamente y no vienen diferenciados con itálicas. Tal vez deseó jugar a continuar engañándonos. Esta es la viñeta que da conclusión al libro: "He logrado acallar las voces que sonaban en mi interior, ha sido un alivio, no sé cómo pude vivir con aquel infierno tras el cráneo. Todo se vuelve simple, como una hoja en blanco, tan perfecto, tan puro. Hay una puerta que se abre. Luz tras el umbral. Se me cierran los ojos" (Mirada de reojo 116).

V. 2. Bad painting y escribiendo bien. El comienzo del juego

En el Primer Forum de Narrativa Cubana (1984) la escritora y ensayista Luisa Campuzano llamaba la atención sobre la escasez de producción narrativa femenina de las tres décadas anteriores (“La mujer en la narrativa de la Revolución: ponencia sobre una carencia"), y en 1996 todavía se lamentaba de que "entre 1984 y 1995 no ha llegado a una veintena de libros de narrativa publicados por autoras cubanas", para agregar que “esto no es del todo imputable a los efectos de la contracción económica que sufre el país”, pero sin aclarar o dilucidar cuáles eran las causas de dicha carencia (Las muchachas de la Habana 141). Sin embargo, a finales de los noventa, la eclosión de cuentos y novelas escritos por mujeres se había convertido en una de las marcas de la literatura cubana del momento.

Las características de las obras de estas autoras que toman por asalto la fortaleza literaria por tanto tiempo en manos masculinas son entre otros: El experimentalismo, el erotismo como fuerza liberadora, la intertextualidad, el desencanto como fórmula de creación y las refracciones del absurdo. También el abordaje de tópicos hasta entonces 
tabúes como la homosexualidad, la prostitución, el éxodo, el SIDA y la marginalidad, comienzan a poblar los textos del amplio grupo de mujeres que salen al ruedo literario insular. Entre las escritoras que la conforman se encuentran Adelaida Fernández de Juan, Mylene Fernández Pintado, Ena Lucía Portela, Karla Suárez y la propia Anna Lidia Vega Serova. Es esta quien se alza con el premio David en 1997 con una recopilación de nueve cuentos alusivos a las artes plásticas en sus títulos y a veces en sus temas y personajes, Bad Painting. De esta manera relata Vega Serova sus comienzos en las faenas retóricas nacionales:

En Cuba, comencé a traducir algunos de mis cuentos del ruso al español. Por suerte coincidí con algunas personas del medio que me impulsaron. Mi esposo de aquel momento, me propuso mandar a un encuentro de talleres literarios municipales uno de esos textos. Gané ahí y en el encuentro provincial, y luego obtuve mención en el nivel nacional. Me sugirieron que siguiera escribiendo y yo me di cuenta de que para mí era muy fácil, que yo podía escribir muchísimas cosas como esas. En unos tres meses armé el libro Bad Painting y luego lo mandé al concurso David. El primer año obtuvo un premio de la Asociación Hermanos Saiz y al año siguiente ganó el David y me dio a conocer como escritora. (H. Hernández, "La literatura")

Con Bad Painting comienza el juego literario de Vega Serova. Jorge Rufinelly describe bien las principales características de los personajes protagónicos que desde entonces con pocas variaciones habitan de los textos serovianos: Primero crea un protagonista "genérico" con su "propio universo", que con variantes y alternativas 
transitará a lo largo de su trayectoria como escritora de una manera más o menos estable. Este protagonista es una mujer joven, habitualmente alejada de los demás, quien establece una fobia social a medida que se relaciona con la ciudad y sus personajes, recuerda una infancia traumática y vive el correr de los días con la angustia de la conciencia sobre la fragilidad e inoperancia de las acciones humanas (especialmente se siente esto en la ausencia de amor). A medida que pasen los años y protagonice nuevos cuentos de nuevos libros, ese personaje "básico" tendrá parejas y relaciones (que se disolverán), explorará la homosexualidad, etc., pero en todos los casos, la felicidad será siempre elusiva (“Anna Lidia Vega Serova de San Petersburgo a La Habana” 43-50).

Esta narradora ha ido diseñando uno de los universos personales más inquietantes de la narrativa cubana del momento. Como asevera Víctor Fowler: "su tratamiento de lo expresionista, monstruoso y grotesco, así como lo rutinario de la violencia y sordidez que habitan sus personajes, carece de paralelos entre los escritores de hoy" (cit. en Jiménez Campo 5).

V. 3. Desde la intimidad. Viñetas y notas al pie. El sexo, el desatino y la marginalidad

Al fin y al cabo, es su propia vida la cosa más cercana que cada escritor tiene para echar mano. Antonio Skármeta

Limpiando ventanas y espejos (2001), tercera obra publicada de Vega Serova, se compone de doce cuentos donde los protagonistas son figuras "raras" o marginales: travestis, mujeres con todo el cuerpo cubierto de pelos, o del mundo de la farándula, que 
es como se refiere comúnmente en Cuba al ambiente en que desarrollan la vida social los artistas: pintores, fotógrafos, pianistas, etc. ${ }^{41}$

El periodista y crítico literario Dean Luís Reyes argumenta sobre la dureza y el desarraigo existencial que se respira en las narraciones de este volumen de esta manera: “Su escritura [la de Vega Serova] es una zona álgida en el diálogo de la nación con su cuerpo, allí donde concurren y se hacen ingobernables - y por ello transparentes-las quiebras, el desasosiego y las pústulas. . ., para Anna Lidia la escritura es centro de su angustia, no la anécdota" ("Pasando el Trapo"). Limpiando ventanas y espejos recrea un mundo ingrávido donde la bondad se ha extinguido y predomina el ímpetu de lo perverso y el mayor de los desencantos. Personajes transmutados en la propia duplicidad de la escritora en su esfuerzo por transmitirnos la pérdida de los valores propios del idealismo. Ya no quedan optimistas. Esa existencia en una ciudad ¿Alamar? que se convierte en un fractal de La Habana, que es a su vez un fractal de la isla que ha quedado olvidada, aislada y sin recursos, hacen de Vega Serova una representante fiel del discurso nihilista, aislacionista y cerrado, siendo las palabras el espacio donde puede plasmar el desencanto. Una de las características peculiares de este libro es la sobre abundancia de notas a pie de página (en casi cada hoja) que intentan ser confesiones íntimas donde la autora refiere, por ejemplo, a quiénes están dedicados los cuentos, o la fuente de inspiración de historias y personajes, o detalles de las situaciones narradas que se relacionan con sus gustos, fobias, o anécdotas personales. Por ejemplo, el cuento que abre el libro

\footnotetext{
${ }^{41}$ Para los que conocen la barriada periférica de Alamar (como ocurre en el caso del autor de este trabajo), lugar donde habita Serova y donde lleva a cabo su peña poética mensual, no se necesita mucha imaginación para reconocer en este volumen de cuentos la cultura de barrio bajo de La Habana, la sordidez de sus calles, la mezcla underground entre prostitución, rap social, delincuencia y enajenación. Por citar un ejemplo, el dúo de rap más contestatario y controversial de Cuba en el momento actual, Los aldeanos, proviene de allí.
} 
“Esperando a Elio", está dedicado a Manín. La autora inserta una nota al pie donde explica quien es Manín de este modo: "Quiero decirles que Manín es un tipo fuera de serie: yo lo admiro cantidad, aunque peleemos a menudo. Manín se llama Manuel Ávila. Es poeta y también es el papá de mi hijo Cristian" (Limpiando ventanas y espejos 7).

Este recurso literario de insertar comentarios "autobiográficos" se ha convertido en una característica de la escritura de Vega Serova. Ya desde la primera página del libro la autora está tratando de atrapar al lector y traerlo a su mundo privado, y de esta manera comprometerlo. El tono coloquial para calificar a Manuel Ávila primero por su apodo "Manín" y luego como "tipo fuera de serie" al que admira "cantidad", es una estrategia que utiliza el narrador para crear empatía.

El comentario, como bien apunta Mónica G. Zoppi Fontana, "es uno de los procedimientos internos de control del discurso y se caracteriza por funcionar como un juego de identidad del texto consigo mismo, como un proceso de repetición indefinida de lo mismo" ("En los márgenes del texto" 15). Paloma Jiménez del Campo refiriéndose a las notas al pie que aparecen en el cuento "La chica que no fuma los sábados" ahonda: "Vemos a través de las dos primeras notas, cómo la autora emplea este recurso paratextual con una doble función: ficcionalizar la vida (la de su amiga Lourdes [a quien va dedicado el cuento] que no fuma los sábados) y otorgarle un fundamento real a lo ficticio (al personaje de la joven hirsuta del cuento). Los sábados son días especiales para la protagonista" ("Casa propia" 7).

Otra de las innovaciones a las que recurre Vega Serova para lograr el rapport con los lectores son las viñetas, en este caso entendidas como textos de una cuartilla o menos intercalados entre los capítulos, en los que supuestamente la autora nos desvela elementos 
reales de su biografía. En su volumen El día de cada día las viñetas intercaladas sirven como reflexión luego de la reciente ruptura con su novia. Aprovecha este recurso como descarga íntima, sensible y lastimera de sus emociones a modo de testimonio. Así ocurre en la segunda viñeta:

A veces me pregunto quién será la loca que escribe estas líneas envuelta en humo de incienso y cigarro. Me volteo para ver su imagen en el espejo. ¿Una histérica bajo tratamiento psiquiátrico por pensar casi ininterrumpidamente en el suicidio? ¿Una lesbiana que intenta vengarse del mundo haciéndole tragar letra a letra sus frustraciones y excrementos? ¿Una princesa envejecida de tanto andar en su laberinto de sueños y ruinas? ¿Una bruja?

A veces me pregunto quién serás tú". (El día de cada día 19)

Otro tanto sucede con el tema de la maternidad, que se vuelve opresiva y por tanto un estorbo para mantener su libertad y su deseada autonomía sexual, como en el caso de Noche de Ronda: "El niño se tiró llorando sobre mí y comenzó a abrazarme. Pensé que con otra entidad podría tener a otro hijo: rosado, gordito, limpio y con ropitas de revistas... ¡Mi niño flaco y eternamente mocoso! Lo abracé también” (39).

El escape se produce hacia el dislate en algún caso, pero sin abandonar el elemento lúdico-sexual: “'Es un caso clínico’-llegaron a mis oídos las palabras de uno de los policías. Me demoré mucho tiempo, incluso les pedí que me enseñaran los penes, antes de comprender: ¿YO soy un caso clínico?” (Noche de ronda 39), o el onanismo: “se bajó el blúmers, se sentó. Temblando de ansias y emoción sobre una roca, suspiró, cerró los ojos, rezó un Padrenuestro a su manera y comenzó a frotarse el clítoris con la mano 
derecha, mientras compartía los dedos de la izquierda entre la vagina y el ano" (Noche de ronda 43$)$.

En 2004 aparece una edición con ocho cuentos recogidos en el volumen Legión de sombras miserables. En "Capirulis menti o efectos secundarios de un cuento anónimo", recogido luego en la antología Nosotras dos de 2012, la narradora, una estudiante universitaria narra en primera persona sus fantasías eróticas con su profesora de Química, mujer que pasa de los cuarenta y es a todas luces soltera.

La evolución de los sentimientos de la alumna, en un principio inocentes: “iPobre profesora! Cuántas veces ha imaginado que tocan a la puerta de su casa y es un desconocido o desconocida, hombre o mujer que llega y la seduce y le regala todo el amor que le ha faltado por años" (57), deriva en alucinaciones sicalípticas que cubren un espectro amplio, desde el onanismo hasta la zoofilia (pasando por relaciones heterosexuales, homosexuales y orgías), todo en un breve relato ${ }^{42}$.

En febrero de 2014 otra antología femenina se publica en La Habana: Palabras sin velo, editada por el Centro memorial Martin Luther King Jr. La misma se compone de una entrevista y un cuento respectivamente de diez escritoras de la isla, entre las que se encuentra Anna Lidia Vega Serova. De acuerdo con la compiladora, la periodista Helen Hernández Hormilla, "el conjunto pretende una mirada global a las principales temáticas femeninas tratadas por ellas, sus actitudes ante la feminidad tradicional, sus necesidades

\footnotetext{
${ }^{42}$ Un ejemplo de onanismo en el cuento se puede apreciar en este pasaje: "Mi profesora de Química difícilmente se masturbó con un cirio de iglesia, habrá usado algo menos ortodoxo, un rodillo de cocina, por ejemplo, o el pomo del perfume que le habíamos regalado por el Día del Maestro, o un pepino que luego cortaría en rodajas". El bestialismo, por su parte, queda expuesto crudamente en este otro: "Paulina [nombre de la profesora] se entrega al simio como al más preciado amante, sus olores le excitan hasta el vértigo, su aliento acre, su salvaje olor de mono le infunden delirios" ("Capirulis menti", Nosotras dos 57, 59). No quedan dudas de que hay una visión completamente desprejuiciada, abierta y transgresora de las relaciones sexuales.
} 
de subversión de un orden androcéntrico, y la posible voluntad reivindicativa" (cit. en García Álvarez).

\section{4. Serova y lo posnacional}

La objeción política, a estas alturas, parece claro que no invalida la pertenencia de un autor al patrimonio cultural de la nación. Aquel escandaloso dislate que propició que un escritor como Guillermo Cabrera Infante no figurara en el Diccionario de la Literatura Cubana, por lo menos sirvió para tomar conciencia del error.

(Juan Antonio García Borrero 66)

Mucho se especula sobre la sinusoide del arte nacional, específicamente la literatura de los últimos años, como una posliteratura. Es preciso mencionar que lo posnacional en Cuba viene acompañando por el desencanto. Como dice Fornet: “el meridiano cultural. . . pasa por cualquier parte de Occidente si se quiere culpabilizar en abstracto, pero sobre todo pasa, sin duda, por el propio omphalos nativo: por el canon del desencanto nacional" (cit. en Picart 3).

En los noventa los nuevos escritores cubanos se reiteran tanto que agobian. Gina Picart se lamenta de la saturación a que se ha llegado repitiendo los mismos temas: "parece haberse llegado a un nivel de agotamiento en que pululan hasta el hartazgo las ya clásicas "jineteras", el onanismo, el sexo homo y hetero, la alienación juvenil, el desarraigo, la marginalidad, los balseros. ... Un momento en que se comienza a escribir exclusivamente para las delicias de jurados (y) o las caricias de un premio" ("Los nuevos paradigmas" 5). Por tanto, se agradece cuando, dentro del desencanto hiperbólico, una autora ensaya ser diferente.

Resulta muy difícil encontrar artistas de hoy con remembranzas mixtas inter artes (Da Vinci, Goya) La modernidad atrae especialización, y la especialización obliga a la 
definición en detrimento de la mixtura. Serova, quizás por su misma sangre duplicada y transgredida, accede y disfruta de la multiplicidad en su indagación existencial mediante el arte. Es cuestionable afirmar que entre los intelectuales que dejaron Cuba en la década de los noventa no se da cierto sentimiento de nostalgia o una cierta idealización del pasado de Cuba, pero sí es cierto que se advierte en ellos un sentimiento de desengaño generalizado.

Este desengaño y la ausencia total de nostalgia por una Cuba actual y pasada se aprecia, por ejemplo, en Iván de la Nuez. Este intelectual que reside ahora en Barcelona, salió de la isla en 1991, como tantos otros cubanos a partir del momento en que arrecia el llamado "Período especial en tiempos de paz". Con El mapa de sal. Un poscomunista en el paisaje global (2001) Iván de la Nuez abre una perspectiva del exilio cubano diferente de la que ha protagonizado lo que él llama el "Exilio Jurásico" (28). Este autor propone la balsa como objeto de culto de los artistas cubanos y "como hundimiento de la simbología nacional" (28). Se proclama exiliado sin nostalgias y se propone dibujar un mapa de sal para posicionarse "tanto frente a los fundamentalismos del comunismo vencido, como en contra de la globalización pletórica de su victoria" (30). Por eso propone un mapa de sal apátrida. De la Nuez plantea una visión crítica y sarcástica del mundo globalizador occidental, pero también del paisaje poscomunista que se ha creado tras la caída del Muro de Berlín en 1989.

En ese espacio podríamos ubicar la obra de Serova. Su personaje observante y desprejuiciado se mueve furtivamente en la narración bajo la forma de mujer, con una vida interior consciente, anhelante, plena de sensualidad y de secretos, congojas, goces y sueños, siempre buscando la complicidad con el lector a través de sutiles y eficaces 
recursos estilísticos. Para Vega Serova, el hecho de coexistir entre dos culturas que entraron en profunda crisis simultáneamente, y en un momento de plena adolescencia (recordemos que nace en 1968), ayudó a desdibujar en ella un nacionalismo oficial, retrógrado e impuesto, para crear una obra intimista pictórica literaria donde no parece haber límites. Su cuentística desafía lo real y lo imaginado. Personajes que existen solo por el gusto de hallarse a sí mismos, que aman y desacralizan su cuerpo, que viven en atmósferas sórdidas y violentas o son dulces amantes de lo cotidiano. Pero lo más curioso, es que a veces las historias de Vega Serova encierran y rebasan todo eso. Existencia marcada en graffitis hippies que buscan la plena libertad humana, desde el contrapunteo ideológico generado entre los escritores dentro de la isla y los de la diáspora.

V. 5. La fragmentación del alma que pena en el vacío. El desarraigo de la identidad Ánima fatua ha regresado a las librerías cubanas. El hecho es un tanto insólito porque las editoriales del patio no tienen el hábito de las reediciones. Cabe pensar que la lógica triunfó por esta vez y se reconoció la necesidad de poner al alcance de nuevos lectores una novela que se esfumó inmediatamente de los anaqueles cuando salió la primera edición, en 2008. Cubanow (Isla de Letras: "Anna Lidia Vega Serova”)

En Ánima fatua penetra más allá de lo estrictamente fenoménico, y va hacia el trasfondo de lo aparencial. Se devela una Serova en plena madurez artística, con dominio de técnicas literarias y capacidad de modular el mundo interior de sus personajes. Supera la crítica tenaz y discutidora de sus anteriores obras, la descripción iterativa de situaciones transgresoras para aproximarse como conciencia crítica. Novela desgarradora e insolente, lanza a Serova junto a las autoras con mayor presencia en el panorama 
literario nacional. Marilyn Bobes expone que "el hecho de que el argumento se desarrolle en la antigua Unión Soviética permite a los lectores un esbozo tangencial de la crisis que precipitó el derrumbe socialista en un país donde los jóvenes optaron por la desesperanza a falta de unos valores éticos que no se correspondían con sus expectativas y posibilidades" (“Todos los demonios" 1).

Novela de formación (bildungsroman) en que la protagonista, especie de alter ego del autor, relata la vida de Alia (simultánea o sucesivamente Alia, Alfa, Fanny o Sofía, de acuerdo a las necesidades de desdoblamiento del personaje). Descendiente de singulares progenitores: madre blanca rusa y padre negro cubano, obligada a vivir a caballo su niñez y adolescencia entre Rusia (entonces todavía comprendida dentro de la URSS o Unión Soviética) y Cuba, Alia es una niña y adolescente desgarrada y escindida entre dos culturas: "partida en dos pedazos irreconciliables, dos mitades en pugna, una combinación incompatible y cruel", a la vez que inocente e infantil.

En la novela se desarrollan los temas del amor en todas sus manifestaciones, los problemas de la identidad, el maltrato filial, la relación con "el Otro", la literatura como meollo de la existencia, los problemas interraciales, el significado de las artes plásticas, el mundo hippie como alternativa de vida, la sociedad soviética de la época de la Perestroika, y otros. Por muy tentador que pueda parecer querer identificar la protagonista y la autora, ¿Alia quizá como "alias" de Vega Serova?, es conveniente tener en cuenta la opinión de esta última en una reciente entrevista:

Lo de la confusión entre la ficción y autobiografía, te diré que aunque me baso en detalles de mi propia vida, la novela está bastante lejos de ser un recuento de mi pasado, quisiera que los lectores logren separarme de Alia. 
Muchas veces utilizo mis experiencias en mis escritos, pero no escribo solo sobre mí. Hay muchas cosas que invento o que mezclo con lo que creo que ha sucedido y el resultado sale bien alejado de la realidad real; no me gustaría que me confundan con mis personajes, aunque sé que los lectores tienden a hacerlo. (Willis 134)

Ánima fatua destaca dentro de su producción literaria por el abordaje de temas álgidos recurrentes como el amor lésbico o las implicaciones de la convivencia rusocubana. También resulta en una suerte de pintura expresionista matizada por las emociones de Alia, su protagonista, de los últimos tiempos de la era soviética (téngase presente que Vega Serova es pintora), y resuena algo de Rayuela de Cortázar por su estructura fragmentaria, a base de capítulos breves que pueden ser degustados de manera independiente. En el primer capítulo cuenta como se produce el encuentro de las padres de la protagonista:

Ella era una mujer sola, muy joven y romántica; le gustaban las películas trágicas con finales felices y los vinos dulces, le gustaba caminar por Leningrado sin rumbo, detenerse en el medio de cualquier puente, mirar el agua negra del Neva sobre la que trazan figuras serpenteantes las luces reflejadas de la ciudad. Ella era joven, pura y muy feliz, aunque creía lo contrario y lloraba por las noches, con la cara hundida en la almohada, y le pedía a Dios - un Dios muy particular suyo - que cambiara su destino. Esperaba de la vida sensaciones fuertes, grandes pasiones, cambios, cambios. Ella era joven, común, y era mi madre, aunque todavía no lo sabía. 
Un día en el comedor de la universidad se dio cuenta de que un hombre la miraba fijamente, o quizá fue cualquiera de sus compañeras la que le hizo notarlo.... En cualquier caso, pasaron mucho tiempo solo mirándose de lejos: él intensamente, sin tregua; ella, rápido, leve, apenas. ¿Tenía miedo? Indudablemente, le temía. No era un hombre común; al menos, no para ella: era un hombre negro....

El resto fue vertiginoso. Saciado de mirarla de lejos, él se le acercó impetuoso, y en un horrible ruso le propuso matrimonio. Ella aceptó casi mecánicamente. Era el mes de las noches blancas: noches insomnes, cuando de día y de noche es de día, y los enamorados pueblan los puentes de la ciudad-ventana. Esta vez la ventana se abría más allá de Europa....

Se llamaba Pedro y era zar. Su zar. Tenía la piel oscura, unos labios gruesos y suaves, unos ojos verdes, las pestañas larguísimas, y un olor exótico a "la playa lejana". "Pushkin", confesó ella. La noche siguiente, tan clara como la anterior, llevó a la cita el primer tomo de su Poeta. Cuando leyó el último verso del último tomo, se casaron. He visto la foto: ella, tan blanca, vestida de blanco; él, oscuro, de traje oscuro, intercambiando un beso.

Exactamente a los nueve meses nací yo. (7-9)

La opinión de Marilyn Bobes según la cual "todos los demonios de Anna Lidia Vega, y también su tierno mundo interior, aparecen reflejados en esta historia que es un canto de amor a Cuba y un acto valiente de honestidad intelectual" ("Todos los demonios 
de Anna Lidia Vega Serova" 4), es compartida con reservas en este trabajo. La presencia de la isla caribeña es inevitable, pero ocupa apenas 4 páginas de un libro de 280. Es el período que transcurre entre los 3 y los 9 años de edad, en los cuales Alia vivirá con sus padres en Cuba antes de marchar de regreso a la entonces aún Unión Soviética luego del divorcio de aquellos. Importante porque Alia encuentra a Malena "el primer amor de [su] vida" (10) y luego descubre en la escuela la ventaja de ser rusa: “Todos los varones querían ser novios míos. Ser novios significaba que me llevaran la maleta, y se sentaran a mi lado, y me dejaran copiar las tares a cambio de un besito en la mejilla de saludo, y otro de despedida" (12).

En otros momentos de la narración, hay un par de menciones aisladas de Cuba, una vez desde el recuerdo nostálgico: "en la cafetería vendían piñas en conserva, algo que me emocionó hasta las lágrimas. Compré una ración, me senté en la mesa saboreando cada trocito de la fruta semiolvidada, cerré los ojos para reconocerla únicamente con el paladar y olfato: 'Cuba'” (117-8), y otra cuando visita por dos semanas a un hermano de la actual esposa de su padre que la invita a Moscú. Allí comparte con aquel y su familia "una latinidad casi olvidada, la música salsa y la comida criolla, mucho café negro y muchas conversaciones al estilo "recuerdas-allá-en-La-Habana"” (90). Pero el grueso de la novela está en función de narrar las aventuras, o mejor dicho, las desventuras de su adolescencia en una Unión Soviética a punto de desaparecer.

Escrita en un estilo aparentemente simple, con personajes entrañables que parecen sacados de un filme, sin permitirse lástima ni juicios, Ánima fatua transita como una mirada hacia el entorno y el interior de un personaje cuya duplicidad escapa de los estereotipos. Obra donde el sexo masculino es violento, las mujeres sin embargo 
fructifican mediante la solidaridad. La manera en que Alia pierde su virginidad a manos del amante de su mejor amiga Elena "el tercer amor de su vida. . ., diez años mayor que [ella] y muy bonita. Tenía el pelo muy negro y los ojos muy negros y la piel muy pálida" (65), no tiene nada de romántico, sino todo lo contrario. El hombre la emborracha un fin de año y de una manera brutal le "desgarró las entrañas”, lo que la lleva a intentar suicidarse: "Recuerdo el dolor. Nunca antes había sentido ese dolor. Tragaba aire, pero no lograba respirar. Después yo estaba en el baño sacando de la envoltura una cuchilla de afeitar, pasándomela por la muñeca una y otra vez, y la sangre se abría en abanico sobre los azulejos verdes" (69).

Otro de los ambiente que recrea Vega Serova en su novela es el mundo marginal de los hippies. Los hippies de la ex Unión Soviética que retrata la escritora solo reproducen las formas externas de vida y conducta del movimiento de los sesenta en los Estados Unidos, sin lograr articular la esencia. Vega, en un alarde satírico, ridiculiza a varios de ellos, haciéndolos vagabundear sin una idea clara de lo que quieren o hacen. Los presenta como simples imitadores de actitudes sin sentido, por el solo mero de hacerlo, idólatras de estrellas foráneas. Por ejemplo, si la imagen de Che Guevara en casa de uno de los cobijadores hippies en la protagonista trae el recuerdo de "Cuba, la escuela, yo de uniforme, parada en una hilera de niños gritando al unísono: ‘ ¡Pioneros por el comunismo: seremos como el Che'", y aún piensa que se trata de un héroe cubano, con toda la inercia política que dicha imagen mantiene para ella, su anfitrión pronto la saca del error y le aclara que "ese es un argentino. .., tremendo hippie y tremendo loco" (161). Es decir, Che Guevara es un hippie más, y el hippie a su vez es la materialización metamorfoseada de aquel alabado "hombre nuevo". 
Otra de las características de la obra es la comparación que establece los cubanos y rusos. Por un lado están los amiguitos cubanos de la infancia con actitudes faltas de prejuicios, mientras que muchos en la Unión Soviética detestan a una cubana hija de rusa blanca con cubano negro, y la primera es la madre: “iMaldito sea el día en que te concebí! — chilla. ¡Y madito sea tu padre y toda tu condenada raza!” (79). La madre es una mujer pálida en afectos, desprovista de cariño, incapaz de mostrar la menos intención de apoyo a su hija en medio del infortunio, quien deviene alcohólica para olvidar sus propios fracasos.

Ánima fatua es la novela del descrédito emocional de un proyecto social quebrado, en el cual solamente queda emplear la experiencia del engaño. Es el resultado de una propuesta de vida que resultó en catástrofe y arrastró a todos al descalabro. Anima fatua verifica la distorsionada imagen de una sociedad que se vendía como ejemplo a seguir y traicionó sus ideales fatuos, representa lo que pudo ser, el sueño truncado, la euforia verificada en la nada.

Obra realizada con pericia y sensibilidad, Ánima fatua muestra a una novelista en pleno dominio de su quehacer estético. Vega Serova llega a la raíz de los traumas de una infancia lacerada por la falta de amor, pasa por la soledad de una adolescente condenada a la incomunicación, es en fin el drama de un ser humano que se siente rechazado y termina por no saber a dónde pertenece, con una responsabilidad que no ha pedido y para la cual no está preparada, en medio de dos terruños cuya historia se desgaja.

Y no es el menor éxito de Ánima fatua el hecho de que el insalvable abismo cultural no aparezca en sus páginas ni una sola vez como acusación abierta o toma de partido evidente. En Ánima fatua todo ha sido mostrado, todo ha sido dicho. 


\section{6. Conclusiones parciales}

El concepto de diversidad cultural no solo se extiende como una mancha de aceite y sigue inspirando políticas públicas respecto de las industrias de la cultura, sino que su creciente audiencia desde el comienzo del nuevo milenio demuestra que las desborda y que tiende a convertirse en una referencia fundamental para la búsqueda de una nueva ordenación del planeta. Los gobiernos se valen de él.

Las agencias del sistema de las Naciones Unidas lo ponen de actualidad. Las asociaciones profesionales y el movimiento social se movilizan en su nombre. (Armand Mattelart 139).

Con una carrera intelectual en desarrollo, amparada ya con importantes reconocimientos y galardones, pero todavía poco conocida fuera de los marcos de Cuba, Serova es de las dramaturgas que han logrado un público diverso que va que desde su círculo literario en el barrio de Alamar (de donde extrae muchas de sus innovadoras ideas), hasta otro más cosmopolita e internacional, resultado de las numerosas invitaciones que ha recibido para dar conferencias en universidades extranjeras (principalmente norteamericanas).

En sus títulos encontramos constantes temáticas como el desarraigo, los personajes tortuosos y la intertextualidad. Los protagonistas de Vega Serova, que transitan entre una violencia rutinaria y una sordidez exacerbada, manifiestan instintos perversos y actitudes nihilistas. Es abundante la presencia de relaciones homoeróticas lésbicas en sus textos, las cuales se consideran más placenteras y creativas que las heterosexuales lastradas por la esclavitud y el sometimiento. El patrón heterosexual se presenta como opresivo, mientras que el homoerotismo para ser reconocido no tiene que darse como fait accompli, pues puede quedar a nivel de posibilidad, deseo y sentimiento. 
Para Serova, ningún personaje es peor o mejor que ella misma: "Uno escribe cosas que saca de su propia cabeza". Sus escritos parecen no tener fronteras, desafían lo real y lo imaginado en constante transgresión, ya sea lésbica, violenta o hippie, con personajes rodeados por ambientes míseros donde no hay lugar para el amor. Su respuesta hacia lo real intolerable y ofensivo es una ficción cargada de desarraigo, de personajes marcados por el estigma de un exilio interior.

Las historias de Vega Serova destruyen las estructuras estables institucionales de la heterosexualidad: pareja estable, familia, maternidad, roles tradicionales de género, vigilancia sobre el cuerpo, para imponer variantes o modos alternativos de satisfacer la sexualidad, no solamente la subjetividad homosexual, sino en ocasiones el incesto, el onanismo o incluso la zoofilia. Ella es además una singular voz femenina que cautiva por su habilidad para simultanear lo bello y lo grotesco de la vida, evitando trampas nacionalistas y traspiés políticos. Sus temas se centran en la desesperación y el desapego, alejadas de un canon que ha dejado de representar a las nuevas generaciones que hoy vagabundean sin rumbo ni motivación.

Escritora que indaga en nuevas y variadas técnicas estilísticas y temáticas, sin abandonar un vocabulario conciso, Serova va desde la catarsis hasta él voyeurismo, desde la ironía hasta la nostalgia, y destaca en sus textos la relación simbiótica entre arte y humanidad, al yuxtaponer personajes y situaciones de disímiles ideologías y naturalezas, que luchan por mantenerse a flote en sus ingrávidos, enajenados y angustiosos mundos. Otra de las características de su escritura es la inclusión de viñetas y notas a pie de página en sus narraciones, recurso para descubrirnos (supuestamente) elementos íntimos y 
autobiográficos. Este es un extracto de una de dichas viñetas, no utilizada en el resto del capítulo:

Ha habido un error. Intento rebobinar los recuerdos, captar el momento a partir del que las cosas rodaron cuesta abajo y no logro comprender en qué me equivoqué. En realidad, he fallado muchas veces, pero intuyo que ha habido algo esencial que no encuentro. Añoro cierta forma de amar, cierta forma de sentir, cierta forma de percibir la realidad. Soy un desastre. (El día de cada día 77)

Mediante un imaginario nutrido de la transculturación entre dos antiguos modelos del bienestar social como fueron los de la URSS y Cuba, la escritora nos diluye en un único mundo: el de la decadencia y el desencanto de un sueño truncado. Unas veces esperanzada, otras violenta, otras ajena, pero siempre lésbica y underground, Anna Lidia Vega Serova participa en la construcción de un nuevo canon: el posnacional. En el próximo capítulo se estudiará otra de sus compañeras de aventuras extraterritoriales: Karla Suárez. 


\section{CAPÍTULO VI}

\section{KARLA SUÁREZ, DONDE HABITA EL VACÍO. LA BÚSQUEDA DE SU CIUDAD}

Mi país no existe. Existe, eso sí, una isla llamada Cuba y avecindada en las aguas poco elementales del Mar Caribe. Por lo demás, cualquier trámite no pasa de ser un asunto más entre la geografía y yo. Ladislao Aguado ("Polvo en el viento")

Olvidadizo de que ya lo era, quise también ser argentino. Jorge Luis Borges (Luna de enfrente)

Bajo el ordenamiento cultural impuesto tras el triunfo de la Revolución de 1959, el intelectual, en la primera década paulatinamente y a partir de principios de los setenta de una manera casi total, dejó de existir como ente individual para formar parte de la "masa" y del "pueblo uniformado", y su obra consecuentemente resuelta en una narrativa negadora y apartada de lo personal. Ese estado de cosas en el cual "es la lealtad el vínculo básico entre los intelectuales y el poder, y la condición de positividad [es la característica] de todos los discursos" (R. Rojas, Isla sin fin 195), funcionó sin contratiempos visibles por más de tres décadas. Las voces discordantes sencillamente no se permitían ni en la literatura ni en la política.

No obstante algunos escritores, sobre todo aquellos defensores o simpatizantes de la Revolución, pudieron publicar dentro de la isla novelas que de manera oblicua y a través de un prisma actual, podrían leerse de manera alegórica como la fábula de la Revolución (y su conversión en dictadura) a partir de algunas constantes que se produjeron en otras revoluciones, ya sea la Comuna de París, la Revolución de Octubre, la Revolución Mexicana, etc. Sirvan de ejemplo las novelas El siglo de las luces (1962), de Alejo Carpentier, y Temporada de ángeles (1983) de Lisandro Otero, sobre las 
revoluciones francesa e inglesa respectivamente. Pero estos casos son la excepción que confirma la regla.

A mediados de los ochenta con la Perestroika (reestructuración) en los sectores de la economía y la Glasnost (apertura) en los aparatos políticos y burocráticos del Estado soviético, impulsados por Gorbachov, comienzan los cambios que eventualmente llevarían a la disolución de la Unión Soviética. En Cuba, todavía en ese momento bajo la esfera de influencia soviética, se impulsa desde la dirección del régimen un proceso similar cuyo objetivo era acabar con el idealismo, la corrupción y otros " "vicios capitalistas' como los errores del economicismo [sic] y del mercantilismo" ("Discurso" 2 de diciembre de 1986) ${ }^{43}$.

Lo que importa resaltar aquí es que de todos esos aires de cambio que se respiraban en los ochenta en la Europa socialista ayudaron a la apertura de espacios culturales en la isla, y entre ellos también en la literatura. Por ejemplo en Santiago de Cuba, Amir Valle y Alberto Garrido entre otros, forman en 1984 lo que se denominó Los seis del 80. Su pretensión, acuñada en el acta de fundación del grupo, rezaba: "Llevar a cabo una 'búsqueda estilística' y realizar un trabajo novedoso y arduo en temas hasta el momento vírgenes en nuestra literatura" (cit. en Uxó 6) , y agregaba, entre otros, el "tratamiento o rescate de temas por entonces muy escabrosos, como el de los fraudes estudiantiles en la educación cubana, las concepciones erróneas predominantes en las MTT (Milicias de Tropas Territoriales) ${ }^{44}$, las anquilosadas injusticias del sistema militar,

\footnotetext{
43 Fidel Castro fusionó los dos términos con el neologismo "errores de mercachiflismo".

44 Las MTT (Milicias de Tropas Territoriales) es parte de la llamada doctrina de la "Guerra de todo el Pueblo". Compuesta por más de un millón de integrantes, de ellos la mitad mujeres, consiste en una especie
} 
la ética machista cubana contra la ética del homosexualismo y la 'otra cara' de la guerra de Angola, esencialmente" (Valle, Brevísimas 9).

Un año después ve la luz en La Habana el grupo El Establo al que pertenecieron Ronaldo Menéndez, José Miguel Sánchez, Verónica Pérez Kónina, Ricardo Arrieta, Raúl Aguiar, Sergio Cevedo y Karla Suárez, quien en aquel entonces era una adolescente de 18 años. El Establo, además de mantener postulados parecidos a Los seis del 80, se distinguía por incluir temáticas centradas en la marginalidad y por un afán de ruptura más radical en lo formal. Varios premios David fueron adjudicados a sus integrantes, con lo que alcanzó cierto empuje nacional antes de su desintegración en 1990. Como dato curioso, vale añadir que este grupo fue frecuentado por Ena Lucía Portela.

Estas nuevas agrupaciones y otras que no alcanza el espacio para mencionar aquí, se forman aprovechando los espacios abiertos por el régimen. En alguna ocasión, como es el caso de los creadores agrupados alrededor del proyecto cultural Diáspora(s) y su revista correspondiente, el proyecto persigue una manera diferente de leer la patria. Como su nombre indica, su propuesta incluía "trascender los límites de la nación y proponer una lectura inmanente de la cultura contra la transcendencia de signo teleológico" (Muñoz 71). Dorta Sánchez explica con más detalles que la revista fue:

Un zamisdat que estos autores editaban, imprimían y distribuían clandestina, precaria e ilegalmente entre los escritores de la comunidad letrada cubana a los que podían llegar (luego estos ejemplares se multiplicaban, en una suerte de metástasis productiva). De tal manera que

de ejército a nivel de barrio. Tuvo su mayor auge a mediados de los años ochenta. Su esencia era en que cada cubano tuviera un lugar, una forma y un medio en la lucha contra una agresión "imperialista". 
con esta empresa pretendían tensar hasta el máximo las complejas relaciones entre el intelectual y el Estado en Cuba: una publicación no autorizada por el gobierno que daba cabida a escritores hasta ese momento prohibidos dentro del país. .., fue ante todo un dispositivo incómodo dentro del campo cultural cubano, asediado por la inminencia de su desaparición y por el nada improbable riesgo físico de sus promotores. (“Discursos posnacionales" 2).

Casi todos los integrantes de este proyecto terminaron marchándose hacia la diáspora real, el exilio. Entre ellos Rolando Sánchez Mejías y Pedro Marqués de Armas, así como un importante colaborador de la misma: Antonio José Ponte. En principio este fue un grupo informal y sin vínculos oficiales, consciente de su papel rompedor, que pretendió hacer temblar las convencionales tradiciones del ensayo y la poesía sobre todo, y transgredir las impuestas normas literarias.

Herederos de esta cruzada intelectual, quizás con menos rigor académico y menos espíritu iconoclasta, pero sí con similar entusiasmo, empezaron a aparecer de manera cada vez más creciente jóvenes autoras en la palestra literaria. En 1996, con la publicación de Estatuas de sal, antología de textos narrativos de escritoras de la isla, se "rompe el hielo", que llevará a partir de entonces a una eclosión que continúa hasta hoy. Mabel Rodríguez Cuesta en coloquio del año 2004 lo recoge de esta manera:

Hay un grupo de mujeres buscando la representación y visibilidad como partes de una realidad en la que también, además de ser musas hermosas, o pálidas y perversas doncellas, o hechiceras y brujas, o lesbianas que provocan imágenes apetitosas a los deseos masculinos, o jineteras perdidas 
ante el dinero y los viajes. . y cuantos tipos de mujeres se te ocurran, son también un cuerpo que sangra con dolor o satisfacción. . ., la memoria de una virginidad perdida con susto y desconcierto. . ., los relatos de la maternidad con su respectiva carga mítica heroica o anti heroica. . ., las sensaciones de ser un monstruo femenino, peludo y encerrado (Anna Lidia Vega). (Cuesta 2)

Aparte de lo anterior, se incorporan igualmente temas considerados tabúes hasta la fecha como los relacionados con las subjetividades homosexuales, el erotismo, la prostitución, el incesto, la violencia doméstica, la pedofilia y la drogadicción. Los personajes que hacen su aparición son también extraños o "raros", y pasan a formar parte de los textos de una manera natural, es decir, no se produce un aprendizaje o mejora por parte del protagonista durante la trayectoria de la narración, y si acaso, un empeoramiento de su vicio. Por lo general se evitan los juicios de valor. Esta incorporación trae a su vez, como lo explica Patricia Valladares, una "transformación y reformulación de conceptos tales como sexo, (homo/hetero) sexualidad y deseo sexual" (13). Aspecto a destacar de esta nueva literatura es el tratamiento oblicuo o lateral de las temáticas sociales, las que se evitan ser referenciadas. Es el "yo" con sus problemas, con sus frustraciones, moviéndose en espacios claustrofóbicos y cerrados, a veces marginales, lo que prevalece.

Rodríguez Coronel refiere que más que la marginalidad lo que importan son los personajes marginales. Es decir, el contexto en que se mueven los personajes puede ser ficticio e irreconocible, de hecho en ocasiones hay una voluntad expresa por parte de los autores de enmascarar el espacio geográfico donde ocurre la acción, pues lo que interesa son las vicisitudes de los protagonistas. Cualquier ambiente urbano es igualmente válido. 
Es importante resaltar en esta nueva promoción de escritoras la abundante autorreferencialidad al mundo intelectual. Muchas de las historias tienen que ver con el contexto universitario por ejemplo. También se centran en la vida de la farándula, de los escritores. Ese sentimiento de culpa, ese sentimiento de vergüenza que acompañaba la labor intelectual, propia de los primeros años de la Revolución, ahora ha desaparecido.

En la obra de Karla Suárez se invita al despliegue del tacto, de los olores, de la música y de los colores. El humor de sus escritos a veces ácido, alimenta la tesis sobre la imposibilidad del arraigo, pues el destino te mantiene vagando por la geografía y la literatura. Mas su dinámica va más allá del discurso nihilista y no queda en una prosa complaciente o fatalista. Suárez es más que una emigrante o una viajante en continuo desplazamiento, es, además una pertinaz observadora del íntimo universo femenino, festejadora de la fortaleza y la independencia de la mujer. Ella ha viajado en el espacio, en el tiempo y en la literatura. Desde Espuma, esta joven literata ha desarrollado todo un discurso retórico donde el peregrinar, válido en su obra y en su vida real (ha vivido en París, Roma, Portugal), y el deseo de establecerse, dominan su hacer. Ha obtenido premios relevantes, participado como jurado de numerosos concursos, posee su página web y de vez en vez imparte algún que otro curso de informática, especialidad de la que es graduada. Dentro de los temas empleados por Suárez no falta la subjetividad homosexual. Con su segunda novela La viajera, publicada en España en 2005 (todavía sin edición cubana), a través de una prosa plagada de personajes autoritarios, independientes y caprichosos, alcanza gran éxito de ventas y crítica y se traduce al francés, italiano y portugués, lo que expande las puertas a la narradora cubana en el mercado literario internacional. 
VI. 1. Biografía. Obras. Reconocimientos

Amo el bronce, el cristal, las porcelanas Las vidrieras de múltiples colores... y las brillantes lunas venecianas Julián del Casal ("Mis amores", Hojas al viento 77)

Karla Suárez nació en La Habana el 28 de octubre de 1969. En 1984 se gradúa en curso elemental de guitarra clásica en el Conservatorio de Música y en 1992 lo hace de ingeniería electrónica en el Centro Universitario Julio Antonio Mella (CUJAE), ambas instituciones en La Habana. Desde niña ya compone poemas y cuentos, y durante sus estudios en la CUJAE comienzan sus visitas al taller literario universitario. En 1994 publica su primer trabajo, el cuento "Aniversario", en la revista Revolución y Cultura, el cual es estrenado en Cienfuegos como obra de teatro en 1996. En 1998 la Fundación Alejo Carpentier de La Habana le otorga la beca Razón de Ser para un proyecto de novela, y ese mismo año se instala en Roma, donde continúa escribiendo, combinando esa labor con la profesión de ingeniera y la enseñanza de la informática.

Ha recibido varios premios de importancia a lo largo de su trayectoria literaria como son: Premio narrativa Manatí (La Habana 1997) por su cuento "En esta casa hay un fantasma". En 1999 en España se alza con el Premio Lengua de Trapo con Silencios, su primera novela, traducida luego al francés, italiano, portugués, alemán y esloveno. Esta obra se publicó finalmente en Cuba por la Editorial Letras Cubanas en 2008.

Suárez fue seleccionada por el diario El Mundo entre los 10 escritores noveles del año 2000 y por el Hay Festival y Bogotá Capital Mundial del Libro entre los 39 escritores más representativos de América Latina menores de 39 años en 2007. En el 2005 escribe lo que se considera por algunos críticos su mejor novela: La viajera, publicada por la Editorial Roca, libro que viene acompañando con un $\mathrm{CD}$, pues la música tiene vital 
importancia en la obra. Canciones como El Concierto de Aranjuez, La vie en rose, y otras diversas y melancólicas piezas musicales se venden con el ejemplar editado en España, ayudando a la promoción del libro. Seis años después trae Habana Año Cero, publicada en Portugal por la Editorial Quetzal. Especie de novela de aventuras donde los protagonistas viven situaciones difíciles en el fatídico y ya mencionado comienzo del “Período especial en tiempos de paz", el año 1993. Un poco como el resto de la producción literaria de esta autora, esta novela es "divertida y amarga a la vez", como ella misma confiesa, y a continuación agrega: "hay algo que siempre me ha llamado la atención, cuando las personas están en una situación límite son capaces de aferrarse a cualquier cosa para sobrevivir y eso hacen mis personajes, intentar sobrevivir cueste lo que cueste" (cit. en Sheyla Valladares).

Suárez también abarca la cuentística con resultados loables. En 1999 se publica el volumen de cuentos recogidos con el título de Espuma por Letras Cubanas, luego reeditado en Colombia en el 2001 por la Editorial Norma. En 2011, con un retraso de 10 años con relación a la primera edición llevada a cabo en España, la cubana Ediciones Unión saca a la venta la colección de cuentos con el título Carroza para actores. La escritora también ha llevado adelante proyectos en colaboración con fotógrafos. La belga Editorial Husson publica en 2007 Grietas en las paredes en versiones en español y en francés, libro que tiene a la ciudad de La Habana como escenario y en donde se reúnen relatos de la autora y las fotos del artista luxemburgués Yvon Lambert. Cuba, les chemins du hasard es el primero de un proyecto de dos libros en conjunto con el fotógrafo Francesco Gattoni y la cubana. Se compone de aventuras y anécdotas en distintas 
ciudades y lugares de la isla y de la península italiana, contadas por Karla Suárez, mientras las fotografías van por cuenta del italiano.

Los relatos "El ojo de la noche" y "En esta casa hay un fantasma" de la colección Espuma fueron adaptados para la Televisión Cubana en 2002. En 2003 traslada su domicilio a París. En Francia ha recibido varias becas de creación literaria, entre ellas las que otorgan el Centre National du Livre de Paris (CNL), la Maison des Écrivains Etrangers et Traducteurs de Saint-Nazaire (Meet), la Agence Régionale pour l'Écrit et le Livre en Aquitanie (ARPEL), en Burdeos y Clermont Communauté, en ClermontFerrand. En el 2008 traslada su domicilio a Lisboa, Portugal, donde reside actualmente. Ese mismo año su novela Silencios fue adaptada al teatro por la compañía de teatro francesa Peu importe.

La escritora figura entre los representantes de la llamada diáspora cubana, en contra posición a lo que podríamos llamar el exilio cubano. Sin entrar en profundidad, por cubano de la diáspora se entiende aquella persona que vive fuera de Cuba pero que mantiene una relación fraternal, o al menos de no confrontación con el gobierno. Es decir que se cuida de hacer ningún tipo de crítica política contra el régimen. Desde este punto de vista, Suárez no es una exiliada, sino una cubana presidente en el exterior. Este estatus le posibilita que al menos parte de su obra se publique en la isla.

En una entrevista concedida a la publicación cubana la La Jiribilla, la escritora, en una respuesta típicamente posnacional a una pregunta relacionada con la difusión de la literatura cubana en Europa respondió:

Muchos editores, periodistas o críticos tiene una idea preconcebida de Cuba y aceptan solo lo que se ajuste a esa idea.... Son como fórmulas, 
como recetas de cocina: un escritor debe hablar de ciertos temas si es cubano, o de otros si es haitiano, o de otro si es mexicano, de lo contrario pueden dejar de interesarse en ti. ... Por fortuna no todos los editores son así, hay mucha gente. . que apuestan por un autor y publican su obra porque creen en él. Hasta ahora he tenido este tipo de editores y la verdad es que no he renunciado a nada y seguiré con ellos mientras pueda, porque no voy a renunciar a nada. (cit. en Hernández, "La diáspora que se acerca a la isla")

VI. 2. Silencios. El interés por el yo y lo cotidiano. La otra feminidad

Si una cosa desarrolló la represión sexual en Cuba fue, precisamente, la liberación sexual Reinaldo Arenas (Antes que anochezca 132)

Silencios es la primera novela de Karla Suárez y comparte muchos puntos de contacto con la novela Ánima fatua analizada en el capítulo precedente. Al igual que en el libro de Anna Lidia Vega Serova, Silencios puede ser considerada una novela de aprendizaje (bildungsroman) de la protagonista principal, en un período de 20 años que van desde su infancia a su madurez. La estructura temporal de la novela es lineal y está escrita en un lenguaje claro y conciso, sin regodeos barrocos. Los personajes no tienen nombre, solamente genéricos: la abuela, Mamá, Papá, el tío, Merca (la merca es una manera de referirse a la cocaína), Cuatro ojos, y la protagonista La Flaca. También están El Poeta y Dios. Este último es muy importante en la vida del personaje principal. Es quien la estimula y ayuda y le enseña sobre literatura: 
Dios era un hombre casado y trabajaba en el ICAIC, donde todos eran jóvenes y todo eran esperanzas de construir un mundo nuevo. En estos tiempos, ya todos eran un poquito viejos y Dios hacía rato estaba sin trabajo y sin mujer, pero no le importaba: estaba lleno de libros y de música y amigos jóvenes, como yo, que acudían a su casa a emborracharse con él, mientras soñaban con ser grandes escritores o poetas. (Silencios 115)

Silencios es la historia de la destrucción y el descalabro de una familia, de una casa, "un apartamento grande lleno de cuartos con mundos diferentes; el de la abuela, una tía soltera, un tío masajista y nosotros tres [la madre, el padre, y la protagonista]" (Silencios 9). Somos testigos también de la destrucción de un proyecto de vida y de un sistema político-social. Que haya habido que esperar hasta el 2007 para ver la primera edición cubana no resulta sorprendente, pues como se dijo antes, en esta novela aparecen múltiples temas por el aparato ideológico y cultural de régimen hasta hace muy poco, entre ellos la participación de los cubanos en la guerra de Angola, que no es vista como una acción heroica y necesaria de solidaridad internacionalista, sino como una guerra innecesaria que solo trajo la pérdida inútil de vidas humanas: "tantos años y al final... demasiados muertos...”(151). Papá, antaño orgulloso y alabado militar y cabeza de familia, quien terminará despojado de sus grados de militar, expulsado deshonrosamente del ejercito y convertido en reparador de televisores rusos, aceptará los dólares que su exmujer trae de Argentina para poder cambiar las gomas de su carro: "gesto simbólico que declara que a extremistas de su naturaleza no les ha quedado más que aceptar el 
nuevo panorama social, aquel en el que solo quienes entren en contacto con la moneda dura, podrán sobrevivir" (Cuesta 190).

¿Pero todo para qué? Como le dice la madre de la protagonista a su exmarido luego de tomar la decisión de regresar definitivamente a Argentina: "Vos perdiste los grados, para qué?, regalamos nuestra juventud, ¿para qué?, En este país hay demasiados pelotudos con poder, y no pienso regalarles un año más de mi vida" (Silencios 202). Este párrafo, que expresa claramente el nivel de desencanto y frustración por el fiasco y por toda una juventud perdida, realmente sorprende en un libro publicado en la isla.

La pedofilia y la homosexualidad, en este caso practicada por el tío, es otro de los temas tabúes tratados; también está la drogadicción con drogas duras como la cocaína, elemento que incluso para el autor de este trabajo resultó novedoso, pues durante la época en que esto ocurre, este fenómeno era inusual, por no decir desconocido.

La Mamá, llegada de Argentina en los años sesenta a estudiar teatro, se enamora de Papá, en aquel momento un joven oficial del ejército “de esos que dieron el paso al frente y lucían el uniforme que tanto gustaba a las muchachas, sobre todo a las progresistas como Mamá, que quedó profundamente enamorada y renunció a su nacionalidad para que mi padre no se sintiera incómodo por andar con extranjero" (9). En aquella época en Cuba para los militares era prohibido mantener relaciones personales con extranjeros, y aun los ciudadanos comunes y corrientes podían verse en dificultades. De ahí se puede colegir muy bien la decisión de la Mamá de renunciar a su nacionalidad, siendo esta la mejor manera de demostrar su lealtad a la Revolución. Este gesto la enemistó con su familia en Argentina. Silencios plantea la idea del destierro afectivo como solución para aquellos que con igual intensidad se incluyen o disienten del 
proyecto revolucionario. La ruptura de relaciones de la familia argentina con la Mamá es exactamente la misma a la que la familia de la casa grande [en realidad recuérdese que es un apartamento] ha condenado al tío mayor (quien nunca aparece en la novela, más que referido) cuando aquel se fue a Miami (Cuesta 189).

Todos se van: La abuela muere. La Mamá regresa a Argentina, y de paso pretende llevarse a La Flaca. El tío homosexual que es expulsado de la casa por culpa de un escándalo que se desata, nunca regresa, y finalmente abandona el país. Sus amigos más cercanos, Cuatro ojos y El Poeta al final también se van para Europa y Miami respectivamente. El Merca, drogadicto irremisible y con quien la protagonista tiene un romance, también opta por irse del país: "esto no hay quien lo tumbe, pero tampoco quien lo arregle, Y yo no aguanto más, ahora que abrieron las puertas, vamos a hacer una balsa y que el último apague el morro" (221), y se insinúa a la posibilidad de que haya muerto ahogado tratando de alcanzar las costas de los Estados Unidos, pues más nunca se tienen noticias de él; la tía, que nunca estuvo bien de la cabeza termina en un hospital psiquiátrico completamente loca. Sin embargo, la Flaca se niega a irse, por lo menos en los marcos de la novela esa salida no se produce. Queda la posibilidad, como en el filme Memorias del subdesarrollo, de un final abierto. La idea de un encierro que dé cauce a esta escritura liberada presenta altos niveles simbólicos—comenta Cuesta—, pues resulta difícil constatarla en la realidad, a menos que quien la lleve a cabo esté subvencionado desde el extranjero, lo cual sería quizá lo que la autora nos insinúa estará sucediendo a La Flaca gracias al apoyo que a partir de un momento determinado recibe de su madre argentina. 
Novela del caos y el desarraigo por excelencia, donde "el amor, esa palabra que tantas vueltas da, podría seguir dando sus giros sin acercarse a mí", no pretende ser un ajuste de cuentas con nada, es un dejarse llevar: "Yo no sabía exactamente qué era lo que quería, pero estaba totalmente convencida de lo que no quería, no quería llorar y hacerme sombra, ni achacarle mis culpas a los otros. Los seres más sensibles son los que más sufren y los que siempre pierden. Y yo no quería perder. Nunca". (Silencios 74). Inconforme con los cánones clásicos femeninos, Silencios exhibe la liberación de la sexualidad impuesta por patrones, sin ir más allá de la autocomplacencia, dando muestras de que el estereotipo del "raro" puede lograr ser poderoso y subyugante en el interior del ser.

La Flaca se desenvuelve con soltura dentro del colectivo freak de drogas, alcohol y música sin darle mayor importancia al amor, la política, la ideología o la sociedad en que se vive. Aquí se da cuenta de los seres que marcaron el mundo de la infancia habanera para los nacidos con la Revolución. Suárez narra con gran firmeza expresiva y al mismo tiempo con gran economía de medios, la formación de una joven que se proyecta a través de los apremios de su familia y amigos más cercanos con la sociedad y con la historia que los ha marcado y que tanto ha exigido de ellos. Mientras, La Flaca se mantiene en casa escribiendo sus historias en una vieja máquina que rompe el silencio.

Época donde se explota hasta la saciedad la rebeldía de los escritores denominados novísimos, quienes exageran la transgresión e inteligentemente aprovechan vertientes literarias que por su repercusión, resultaban de mayor interés. Como se ha dicho antes en este trabajo, la literatura de estos años se caracterizó por la tendencia a sustituir el periodismo. La propia narradora de Silencios así lo confirma: 
Me parecía que en Cuba la literatura la escribían los políticos, el resto eran redactores, colocaban signos de puntuación, le daban un título y voilà, la littérature. No sé si sería la carencia de un periodismo verdadero, pero se me antojaba que los escritores hacían periodismo. Nadie contaba historias. Todos decían lo que yo podía ver con solo asomar las narices fuera de las paredes. Hablaban de gente fugándose en balsa de la isla, jineteras en las noches de La Habana, el dólar que subía y bajaba, la esperanza que bajaba y bajaba. Resultaba aburrido. (Silencios 220-1)

El autor de este trabajo coincide en este punto con la protagonista, más que literatura a veces parecía reportaje, pero es que faltaba periodismo, faltaban las noticias, la sociedad estaba cambiando rápidamente, la gente estaba llena de preguntas y los escritores se hacían las mismas preguntas en sus textos. Si se contrasta la ficción que se escribía en esos años con la prensa que se publicaba, la ficción va a ser una fuente más autorizada y fidedigna para conocer la realidad de la época. Curiosamente, a pesar de la propia cita anterior en donde la narradora critica la literatura como crónica, una de las lecturas de Silencios lleva a los mismos resultados. Una de las lecturas de esta novela en estos momentos permite leerla como crónica de un período convulso en la historia de la isla.

VI. 3. De Carroza para actores a Fin de siglo. Del carnaval a la decepción

El peso de la ortodoxia del testimonio . . . es aligerado y desplazado, hacia la condición de componente testimonial en la obra de la más reciente promoción de narradores cubanos. Dicha desautomatización del género se resuelve subvirtiendo algunos ejes del discurso: el ideológico, el referencial, el formal y el argumental.

Ronaldo Menéndez ("El gallo de Diógenes”, Revista Encuentro 222) 
Luego de 10 años de impreso en España, aparece en 2011 en las librerías cubanas Carroza para actores, un libro de cuentos sobre historias encontradas que transcienden el mundo harto explotado de los temas marginales en torno a friquis, drogadictos, “jineteras”, homosexuales y lesbianas. Carroza para actores destaca por su originalidad. De pluma ágil y dinámica, Karla Suárez nos entrega un libro dividido en cuatro partes, concebido como una obra teatral-musical, cada una con tres historias que van desde la búsqueda íntima de la emancipación, hasta la imperiosa necesidad de amar y ser correspondido. Esta estructura, así como la división y el título de las secciones, recuerdan la formación musical de la escritora (sus otras dos pasiones son la literatura y la programación en computadoras), ejecutante de guitarra clásica egresada con nivel elemental de conservatorio a los 15 años (I. Sánchez "Según Karla Suárez, Ellos mienten").

La primera parte, Allegro ma non troppo, se sumerge en la filosófica reflexión sobre la urgencia de libertad individual mediante los cuentos: "La Coleccionista", "Joni Mitchell estaba cantando blues" y "Desvarío". El segundo segmento, Adagio, nos introduce en la búsqueda de la realización personal en un mundo donde prevalecen la soledad y falta de comunicación a través de los cuentos: "Fin de siglo" [se le dedica un espacio más abajo], "Carroza para actores” y "La baby sitter". De la tercera entrega, Andante, son las anécdotas "Problemas del corazón”, "La estrategia" y "El viaje”. Las cuerdas se han tensado y nos encontramos atrapados entre desencuentros, encuentros, rupturas, miedos, esperanzas, desasosiegos. El cuarto y último episodio, Andante cantabile, está integrado por las narraciones "Hay días en que realmente debería suicidarme", "Ganas de volar" y "Las notas falsas". En este cierre se recrean historias 
enmarañadas, fracasadas, incompletas, es el reflejo del día a día de muchos de sus lectores en la vida de la isla, que sentirán bajo los párpados el haber contemplado una esquela de relatos auténticos.

De Carroza para actores dice su escritora:

Son personajes tan intensos que a veces rozan en el delirio, pero es precisamente esto lo que los vuelve interesantes para mí. Hay enamorados y suicidas, solitarios y maníacos, unos seguros de sí mismos y otros completamente desorientados, y todos buscan ser felices, aunque, como dije antes, el concepto de felicidad es personal y si implica a más de uno pues las cosas pueden complicarse, entonces vienen las desdichas. Pero no me gusta decir que están marcados por la desdicha (yo les tengo cariño), ellos simplemente viven y sí, a veces las cosas no les salen muy bien, pero eso es parte de la vida, ¿no? (cit. en Hormilla, "Enferma de optimismo”)

Karla Suárez se postula como experta en la soledad de las almas con su cuento "Fin de siglo", donde las disyuntivas y sus análisis psico-sociológicos se trasponen a través de un recurso novedoso: El encuentro físico como [des]aliento al imaginario virtual. Los desencuentros y desamores muestran el interno mundo de la desesperanza en esta fábula [cíber] nihilista:

Leonardo, ¿estás ahí?, soy yo, Leonardo, acabo de entrar, voy por un cigarro y regreso, dime si estás ahí. . .

Leonardo, ¿dónde estás? Si no apareces cierro, porque tengo hambre, solo quería darte las buenas noches, acabo de llegar a casa, ¿estás ahí? 
¡Anais! Hola, princesa, te estaba esperando, ¿cómo estás? ¿por qué demoraste tanto esta noche?, estaba hablando con Roberto 35, y por eso no te respondí enseguida; cierra y nos vamos al privado, estoy feliz ("Fin de siglo" 309)

Recurso para ejercer la transgresión de manera virtual, impersonal, aislada, donde uno puede ser quien desee, llamarse como le plazca, manejar cualquier profesión y vida. Crear un perfecto Avatar personal para sobrellevar el peso de la vejez y soledad. Cuento sobre la decepción de la realidad frente a la esperanza de la ilusión y la mentira: "Habían prometido no mandarse fotos nunca. Ellos serían ellos mismos sin necesidad de un rostro etiquetado dentro de un montón de bits. Así serían libres de conocerse e incluso de imaginar los gestos que pudieran estar al otro lado de la línea" ("Fin de siglo" 310). Cubiertos por el anonimato que significa el chat, Anais y Leonardo han tejido un enmarañado imaginario el cual, ante la inminencia del anhelado y temido encuentro, caerá como castillo de naipes: “¿Y si lo decepciono? Seguramente me cree más joven, o a lo mejor me cree de mi edad, pero no le gusto. Si le resulto fea no será capaz de decirlo, pero no dirá más nunca que me ama. Quizá fue un error no mandarnos fotografías, ni siquiera sé cómo se llama verdaderamente” (“Fin de siglo" 313). Esgrimiendo ágiles y sorpresivos finales, en esta ocasión utilizando la internet como trasfondo, el encuentro / desencuentro amoroso a través del éter, una vez concretado en la realidad los hace evitarse y lo que pudo ser una historia de amor concluye en el peor de los fracasos y con la más burda justificación:

Anais, amor mío. No imagino qué habrás pensado cuando no me viste llegar al bar. Todo ha sido un desastre, parece que la fatalidad me 
acompañará por siempre. Mi ex mujer, aquella que no veía desde hace tantos años, tuvo un accidente y está hospitalizada, casi al borde de la muerte. Cómo no tiene parientes, me toca ir para ayudarla. Parto de la ciudad y no imagino por cuanto tiempo". ("Fin de siglo" 317)

Como se dijo antes, este volumen de cuentos, originalmente aparecido en 2001 en España, vino a ser publicado en la isla 10 años más tarde. La ciudad donde se desarrolla la narración (no mencionada en el texto) a finales de siglo, que podría ser cualquiera de Europa o de América Latina, está descartada que sea La Habana u otra urbanización o pueblo del interior de Cuba. En la mayor de las Antillas en 2014 la inmensa mayoría de los ciudadanos no tiene acceso a Internet, y mucho menos a un servicio de chat en tiempo real. En ese sentido se puede afirmar sin temor a equivocaciones el carácter posnacional del cuento.

En 1999 Karla Suárez incursiona con una historia que abre la colección del libro Espuma: "El ojo de la noche", en la cual el protagonista femenino defiende un tipo de sexualidad placentera, y mantiene una actitud a favor del auto reconocimiento. En el cuento la protagonista, una joven que vive una vida bastante anodina con su enamorado: "La siguiente noche fue como de costumbre. Jorge sudando encima de mi cuerpo y yo acelerando el movimiento para dejarlo exhausto. Luego la pausa. El suspiro final y Jorge echándose a mi lado boca abajo, murmurando un diminuto 'hasta mañana"' (8), recibe un regalo de este consistente en un telescopio. Regalo que le va a cambiar la vida cuando empieza a observar cada noche a un hombre que vive en el edificio de enfrente y que siempre trae nuevas conquistas amorosas al apartamento. Convertirse en voyeur y tratar de adivinar noche por noche el misterio del vecino la lleva a reflexionar sobre su propia 
vida: "No sé, los hombres no soportan estar solos. Él llenaba sus noches de mujeres y luego, ¿qué? ¿qué nos cura del gusto del vacío?... La noche es el gran espejo. Uno se empeña en construir el todo con remiendos, Como partes de un mosaico infinito, pero algo sucede cuando estos subterfugios se convierten en bufones burlándose de nosotros" (11).

Desde el claustrofóbico apartamento, con un liberador balcón desde donde se concibe la esperanza a través de un catalejo, mientras su pareja duerme luego del rutinario sexo, la protagonista imagina la vida afuera del asfixiante espacio reinventándose historias a pesar de sentirse insignificante: “Él la acercó hacia así y supe que se besaban sin importar que yo mirara desde acá. Yo ¿qué era? ¿qué podía determinar? Nada, absolutamente nada, conclusivamente nada" (14).

En "El ojo de la noche" la imaginación femenina ayuda a la mujer a conocer su propia realidad, una experiencia fracasada de amor heterosexual, y deja abierto un abanico de infinitas posibilidades y un futuro por crear (Cabrales 80). Karla Suárez motiva y cautiva con un entendimiento eficaz de la percepción de lo contemporáneo. Historia sobre el amor verdadero observado por un catalejo, mientras reflexiona sobre su vida, escenas que ocurren a ambos lados del catalejo y que son utilizadas para eliminar una relación y forjar su propia libertad. Voyeur incorregibles que se repiten en su obra y que son parte importante también de la escritura de Anna Lidia Vega Serova y Ena Lucía Portela. 
VI. 4. La viajera. Antecedentes. Las nostalgias y las añoranzas

Te hablaré de la vía y por lo tanto puedo llamarte viajero, caminante, vagabundo, pero prefiero llamarte buscador, ser que prefiere andar en vez de quedarse en casa. Mario

Corradini (El Buscador)

Desilusionada de la relación con su prometido cubano, Iluminada Peña se pone a coquetear y finaliza casada con un francés, terminando por exiliarse en Francia. Marilyn Bobes (Pregúntaselo a Dios).

La viajera trata del viaje de búsqueda hacía sí mismas y hacia fuera de dos amigas cubanas mientras buscan su propio espacio en el mundo. Una cubana que añora su Habana natal desde la diáspora romana, frente a otra que busca con anhelo "su" ciudad, que definitivamente no es La Habana pero que no encuentra en parte alguna. La mayoría de los personajes de la novela no viven en la ciudad que los vio nacer, nunca dejan de ser "alguien que vino de fuera", con todo lo que ello comporta, porque el que emigra, sea cual sea el motivo, lleva dentro de sí parte de la ciudad natal y si vuelve a ella tampoco es el mismo porque arrastra todo el polvo del camino. Ese parece ser el sino de la época.

En cierta manera, es lo que les pasa a los personajes, mezcla de varios lugares sin ser nunca ciudadano del todo de uno. Como un anuncio premonitorio del desmantelamiento de la nación, los personajes de Suárez en La viajera van creando un imaginario poco fiable, interferido por la nostalgia del que parte y la inconformidad del que se queda, ambos representando la distorsión de una realidad nacional que se debate entre dos aguas. Roberto Bolaño desarrolla este tema cuando comenta que viajar es un acto igual al respirar como destino precondicionado de vida y resulta imposible detenerse: "Realmente es más sano no viajar, es más sano no moverse, no salir nunca de casa, estar abrigado en invierno y solo quitarse la bufanda en verano, es más sano no abrir 
la boca ni pestañear, es más sano no respirar, pero lo cierto es que uno respira y viaja" (cit. por Jungwon 182).

Como se ha visto antes en este estudio, los escritores en los años noventa como generalidad presentan una visión marginal y de crisis de valores, de vacío y de desesperanza. Sin embargo, en esta novela el autor mantiene viva la esperanza sin una nostalgia corrosiva, a pesar del desarraigo y la soledad. La Viajera puede ser situada en el catálogo de obras posnacionales que participan, entre otros de los nihilismos explícitos, tanto pasivos como activos, tal y como los define Castany Prado: "Nihilista explícito pasivo en cuestiones nacionales sería aquél que se da cuenta de que la nación es una realidad condenada a desaparecer tal y como él la había concebido hasta el momento, pero que no es capaz de sobreponerse a dicha pérdida.... El nihilista pasivo cree que si la nación desaparece él ya no podrá tener una identidad clara y precisa" (94). Por su parte:

El nihilista explícito activo. . . acepta, si no con alegría, sí con valentía o curiosidad, la muerte de la nación.... [N]o existe una sola propuesta nihilista activa sino todo un cúmulo de propuestas posnacionales que coinciden en afirmar la necesidad de difundir una mirada cosmopolita que dé cuenta y se enfrente a la efectiva cosmopolitización de la realidad. (96) Lucía y Circe son, respectivamente, representantes de cada uno de estos modelos posnacionales. Para la primera, la nación se mantiene durante todo su peregrinar como punto obligado de referencia. Allí quedan su familia y sus amigos, y no puede desprenderse de una vez y por todas de esas ataduras. Laura necesita la referencia de su patria, sus acciones se subordinan a la aprobación, siquiera simbólica, de aquellos que 
quedaron en la isla. Circe por su parte acepta con alegría y sin tapujos la muerte de la nación, concepto obsoleto y vacío que para ella no significa nada. En realidad la nación que quedó atrás no tiene ninguna importancia, y para nada influye en su toma de decisiones. A pesar de no haber llegado a ninguna parte, Circe "vagaba y vagaba, siempre buscando sin encontrar, A pesar de su sonrisa y su particular manera de relacionarse con el mundo y definirlo" (96).

Karla Suárez pertenece al mundo de los escritores, como explica Castany Prado, que rechazan dejarse encerrar en categorías que no dan cuenta de la complejidad y la ambigüedad de las identidades individuales. Hay puntos de semejanza entre La viajera y los protagonistas del cuento "Los desarraigados", de la escritora uruguaya exiliada en España Cristina Peri Rossi, pues aquellos "piensan que permaneciendo mucho tiempo en la misma ciudad o país es posible que alguna vez le sean concedidas unas raíces postizas, unas raíces de plástico, por ejemplo, pero ninguna ciudad es tan generosa"

\section{(Cosmoagonías 139).}

La búsqueda de una identidad propia, cargada de reflexiones y con pulso muy bien manejado por la escritora a través de sus personajes, obtuvo de La Viajera lo que muy pocos textos de noveles escritores: una extensa cobertura por parte de la prensa internacional. El diario Deia del País Vasco expuso que la obra era "una historia imbuida de reflexión vital, emotividad e intuición”. Los críticos franceses de La Gazette expresaron: "Una novelista ha nacido: Karla Suárez. De origen cubano, esta prometedora semilla de autor se implanta definitivamente en el paisaje literario contemporáneo para enriquecerlo con una escritura original, moderna, directa y lúcida, en un terreno tan negro como fértil: la sociedad cubana actual". A vous libre, refiriéndose al desarraigo comentó 
que La viajera era "una novela marcada por la ausencia de la isla, de una verdadera casa. ... Es también una novela sobre el exilio y las ciudades. Tiene páginas maravillosas sobre las ciudades de viaje de Circe y sobre la imposibilidad de sentirse de algún lugar una vez perdido nuestro propio origen", criterio compartido por la prensa colombiana: "Más que una búsqueda de la ciudad que esté a la medida de sus deseos, es una búsqueda de identidad: una identidad, podríamos añadir, personal, individual, alejada del concepto de identidad colectiva tan querida por los protectores del nacionalismo cubano.

La viajera califica como obra posnacional en la medida en que recupera la presencia de personajes culturalmente confusos en el sentido de su posible adscripción a culturas radicalmente diferentes. A la vez concibe el cosmopolitismo como un acompañante cotidiano de la vida contemporánea. Se va definiendo, en sintonía con este sentir, un tipo de estilo que Castany llama "mundialismo literario", caracterizado por enumeraciones que trascienden el ámbito nacional, el uso de palabras de campos léxicos muy conocidos y difundidos en el plano mundial, la evocación de la diversidad y mezcla de idiomas debido a los movimientos migratorios y a la influencia de los medios de comunicación y el despliegue de recursos formales en sintonía con el ya mencionado escepticismo (Literatura posnacional 155-6).

Por lo que respecta a la narrativa, Castany Prado da cuenta de las "perspectivas vértigo", consistentes en violentos cambios de enfoque espacio-temporal, referencias a la simultaneidad de ciertos fenómenos mundiales y ciertos espacios internacionales de dimensión mundial, todo lo cual hace comprensible la sintonía que la literatura posnacional mantiene con la literatura de viajes, la picaresca o la literatura pacifista (Literatura posnacional 356-7). La viajera nos ofrece su mirada a una Cuba errante a 
partir de dos personajes contrapuestos y complementarios. En sus líneas hay una referencia lúcida a los incidentes de una comunidad dispersa que busca su lugar en el mundo. Libro intimista sobre la vida de dos mujeres, sus sueños, ilusiones y añoranzas, en La viajera el desarraigo es protagónico. Los personajes no viven en la ciudad que los vio nacer, con todo lo que esto comporta, aunque lleven dentro de sí parte de la ciudad natal. Diario o relato de viajes del exiliado, contrapunteo entre dos arrastres transcendentales: la ausencia de las raíces y la necesidad de arraigo, la persecución de una quimera y la huida de lo nacional conocido. Con relación al cosmopolitismo presente en el personaje de Circe, dice Mabel Cuesta:

Circe, como nombre propio, además de no responder a ninguna simbología específicamente nacionalista, se inscribe perfectamente en un marco de referencias de cultura universal. Así, refuerza la idea del viaje no como una maldición local a la que pueden estar condenados solo sus coterráneos, sino como un propósito ontológico de tan larga tradición como la misma historia de las civilizaciones. (Cuesta 199)

Lucia, a contrapelo, arremete contra el capitalismo y el consumismo: "Querida señora, le proponemos el aparato fundamental para estar en forma. Una especie de pedales donde simulas que caminas, aberrante. ¿Para qué tendrá que comprar algo que simule los procesos naturales? Como si no fuera más fácil caminar (15).

Lo que se cuestiona en La viajera es la noción de Patria, entidad intangible que puede llegar a través de la música, la comida, el lenguaje o la expresión corporal. En una de las entrevistas divulgadas en Cuba sobre La viajera (libro que por cierto aún no se ha 
publicado en la isla) se le preguntó a Karla Suárez: ¿Cómo fue el viaje de este libro, cuáles satisfacciones le ha dejado? La joven escritora respondió así:

En algunos lugares me fue mejor que en otros pero, en general, ese libro me llevó a algunos sitios que no conocía y me permitió conocer gente muy interesante... Otra cosa bonita que me pasó hace poco tiempo fue que encontré un librero en Nueva York y me dijo que solía recomendar La viajera y poner el disco en su librería (la edición española incluye un CD con la música de la novela).Yo ni podía imaginar que allí se encontrara el libro en español, pero los libros son así, como los hijos, salen de casa y cada cual hace su vida, yo espero que su viaje aún no haya terminado. (cit. en S. Valladares)

La viajera es una obra íntima donde el hecho de no pertenecer a parte alguna es manifiesto. Nos va develando transformaciones, quimeras, dudas y añoranzas. Lucía es una cubana que echa de menos su Habana aunque le gusta Roma, mientras que Circe es una cubana que aún no ha encontrado su ciudad y la sigue y seguirá buscando para no sentirse extranjera en cada lugar que pisa. La mayoría del resto de los protagonistas no viven en su ciudad natal, portando en su interior parte de su terruño. Sin embargo, al regresar a sus lugares de origen ya no se sienten autóctonos, pues han sido transformados por otras culturas y quehaceres.

Circe y Lucía son dos mujeres cubanas que deciden construir su vida fuera de la isla. Se conocen en São Paulo, Brasil, donde comparten apartamento juntas por un tiempo. Posteriormente Lucía se marcha y establece residencia en Roma con Bruno, un italiano que había conocido mientras trabajaba de camarera en un restaurante de São 
Paulo, con el que se casa. Circe, en cambio, sigue viajando en la búsqueda de su lugar en el mundo, mientras toma nota de todas sus peripecias y consideraciones en su Cuaderno de Bitácora (especie de diario). El contacto entre las dos amigas se reduce entonces a las postales que Circe envía desde las distintas ciudades que visita en su peregrinaje.

Seis años después de verse por última vez, Circe llega a Roma con un hijo (cuya existencia Lucía desconocía), un bonsái y su Cuaderno de Bitácora, que da a leer a la amiga. A partir de este momento, la vida aparentemente estable del matrimonio LucíaBruno va a perturbarse. Lucía descubrirá la aventura vital de Circe durante los años de separación, asistirá a un testimonio distinto del tiempo vivido en Brasil y, sobre todo, se enfrentará a sus propios miedos. La novela se mueve entre el presente en Roma y el pasado plasmado en el Cuaderno de Bitácora de Circe. Ante los ojos del lector se traza un lazo de amistad inolvidable: Circe, extraña y seductora, extravagante y diferente, capaz de estimular con su presencia la vida de los demás, es además una mujer de difusa y vigorosa sensualidad.

En la novela la música también es protagonista. En el ir y venir por São Paulo, Ciudad de México, París, Madrid y Roma cambia la melodía que los personajes escuchan. Es la ficción de un viaje en el que se delibera por qué o de qué depende que te sientas o no extranjero en un lugar determinado donde algunos se sienten bien, otros quieren regresar a su país, encontrar otro destino y demás.

Suárez refuerza la importancia de la escritura como recurso para conjurar la pérdida de la memoria y aliviar la crudeza de la realidad, algo susceptible de ser experimentado tanto dentro como fuera de la isla. Es por ello que Circe siempre lleva consigo los Cuadernos de Bitácora durante su perenne deambular transnacional. Para 
Mabel Cuesta, Circe "tiene la urgencia de documentar su vida y tematizar la especial relevancia de la memoria” (200) y desde ahí parte al darle razón de ser a su escritura como un ejercicio para no olvidar. Lucía, sin embargo, lucha por mantener su identidad siempre con una mano atada a la patria.

Por sus características La viajera puede ser considerada una típica obra posnacional. Nos encontramos a las puertas de un tipo de literatura en que, como diría Appadurai, "el Estado-Nación, tal y como lo conocemos, se encuentra en su fase terminal. En el largo plazo, ya libres de los constreñimientos de la forma nación, puede que descubramos que la libertad cultural y que una forma sostenible de justicia en el mundo no tienen por qué presuponer la existencia general y uniforme del Estado-Nación. Esta inquietante posibilidad podría ser uno de los dividendos más apasionantes derivados del hecho de vivir en una modernidad sin contenciones" (Appadurai 24).

\section{6. Conclusiones parciales}

Si el emigrante debe conservar en su país de origen todos los derechos, formales y materiales, incluidos - por supuesto - los políticos, la organización de estas significativas conferencias La Nación y la Emigración deben, muy pronto, dejar de ser organizadas por

el Ministerio de Relaciones Exteriores, pues los interlocutores del Gobierno no son extranjeros, sino cubanos. Roberto Veiga González (“La nación y la emigración” 27)

Karla Suárez busca un nuevo discurso reconfigurador del imaginario dentro de un género donde la escritura protagonice una nueva identidad, ahora fragmentada entre la tribulación y la ilusión. Es una mujer errante con la mirada enfocada hacia el mundo (interior también) y sus habitantes. Plasma por una parte el desarraigo y por otra la esperanza, y diseña la mentalidad de los emigrantes y su alegre añoranza por su tierra 
natal, ofreciendo un testimonio sobre la emigración y el desplazamiento, con o sin destino prefijado, cimentado alrededor de las opciones de las protagonistas femeninas.

$\mathrm{Al}$ igual que en algunos de los personajes de sus cuentos y novelas, la propia Karla Suárez sale también del molde estrecho del nacionalismo oficial para vagar por el mundo haciendo música, poética y arte. Es una de las voces literarias de una generación de creadores irreverentes surgidos dentro de la Revolución cubana, pero que se alejan del nacionalismo impuesto por el oficialismo.

Las características básicas de los temas y personajes que Karla Suárez desarrolla en su obra (poesía, cuentos y novelas), son de manera concentrada los de mujeres que progresivamente se aíslan, con cuerpos no convencionales que son utilizados como arma de poder transgresor. Estos seres inadaptados, muchos de ellos a partir de infancias traumáticas, se encuentran en una constante búsqueda de un imaginario personal. La satisfacción elude a los personajes, inadaptándolos. El abuso de estupefacientes, del alcohol, la promiscuidad, la sordidez y la homosexualidad forman parte de lo cotidiano en la obra de Suárez.

En sus escritos siempre se va a la búsqueda de un sentimiento puro, aunque el novísimo posnacionalismo se encuentre plagado de una pretensión desintegradora, áspera y autodestructiva; en Karla Suárez encontramos una lectura diferente. Como expresara Amir Valle sobre la obra de esta escritora:

Leer una historia sobre el deseo y la búsqueda del verdadero amor sorprende y confunde dentro de este panorama temático..., aunque comparte con algunas de sus colegas promocionales ese afán desintegrador, burlesco, incisivo y hasta destructivo del universo en que se 
mueven sus personajes e historias, se diferencia del resto por salvaguardar lo humano que todos poseemos. (Brevísimas demencias 101)

De las tres escritoras escogidas para acercarnos a la vertiente posnacional cubana, resulta necesario hacer la siguiente salvedad: Karla Suárez, a pesar de la transgresión con que dota a su cuentística, revela también la intención de rescatar valores. Amir Valle, corroborando esta línea de pensamiento dice: "aunque comparte con algunas de sus colegas promocionales ese afán desintegrador, burlesco, incisivo y hasta destructivo del universo en que se mueven sus personajes e historias, se diferencia del resto por salvaguardar lo humano que todos poseemos (Brevísimas demencias 101).

A través de sus personajes, Karla Suárez se afana en reconstruir la nacionalidad diaspórica desde su privilegiada estatura posnacional, y reivindica a la mujer y sus derechos. Pero esto no lo realiza (afirmación válida también en los casos de Vega Serova y Portela) desde una literatura de género, etiqueta que siempre ha rechazado para referirse a su obra. Si aparece en antologías femeninas es porque es mujer. La misma Suárez asevera: "Siempre me ha molestado la diferenciación de 'literatura femenina', porque nunca he escuchado que exista la 'literatura masculina'. .., no estoy pensando particularmente en mi condición femenina a la hora de escribir”. Ella reconoce, no obstante, el denuedo que puede tener la literatura más allá de los valores estéticos: "No creo que la literatura pueda cambiar la realidad, pero sí que puede llamar la atención sobre ciertos aspectos, claro, en el caso de que el libro llegue a muchas manos" (cit. en Hormilla, "Enferma de optimismo"). 


\section{CAPÍTULO VII}

\section{LA RUPTURA CON LO FORMAL EN ENA LUCÍA PORTELA. CON LAS}

\section{ALAS ROTAS. . PERO VOLANDO LEJOS Y ALTO}

... se volvía a las enseñanzas de la vanguardia, a determinados prosistas europeos, al universo del rock, al mundo de la mujer, a los espacios imaginarios, al minimalismo, a la filosofía occidental y al orbe del sexo y de la noche, esta última como útero del mito de la ocultación.

Alberto Garrandés. (La cuentística cubana del siglo XX)

-¡Ah, la gran incógnita! - dijo el doctor- ¿Has pensado en todas las puertas que se han cerrado por la noche y que han vuelto a abrirse? . . . Reúne esos mil ojos en uno solo y taladrarías la noche con el gran foco ciego del corazón. Djuna Barnes (El bosque de la noche).

La victoria revolucionaria trajo aparejada el imaginario del santo supresor de las viejas, obsoletas y republicanas creencias nacionales. En un principio, el mismo Lezama Lima fue cautivado con el encanto de los barbudos: "La Revolución significa que todos los conjuros negativos han sido decapitados. ... Comenzamos a vivir nuestros hechizos y el reinado de la imagen se entreabre en un tiempo absoluto. Cuando el pueblo está habitado por una imagen viviente, el Estado alcanza su figura" (Confluencias 339)

El santísimo influjo no duró demasiado. Los nuevos mitos resultaron catastróficos. Rafael Rojas en su disertación "El intelectual y la revolución. Contrapunteo cubano del nihilismo y el civismo", relata:

La mayoría de los intelectuales cubanos. .. se dejó arrastrar por ese frenesí que, más que un conjuro o exorcismo, era una expiación colectiva: la expiación de la culpa del nihilismo, de la apatía, del frívolo y provinciano simulacro de cosmopolitismo, de la ausencia inveterada de vocación cívica. Descubierto en su complejo de culpa frente a un joven poder que, a 
su vez, estaba envanecido por una popularidad arrolladora, el intelectual cubano se propuso, como quería Marx, cambiar su rol de educador por el de quien es educado. (86)

La mujer en el canon nacional posterior a 1959 no ha pasado de ser un estereotipo de los deseos masculinos. Son escritores, escultores, cineastas y músicos (hombres) los que colocan los arquetipos de la mujer, quien ve relegado su hacer cultural (con sus consabidas excepciones) a un pasivo rol en pos de mantener los logros de la Revolución: El icono con que quedaron identificadas las mujeres [A partir de los 60] insiste en la idea de una posible lucha armada que se alienta hasta nuestros días a pesar del fin de la Guerra Fría. Se trata de ese exacto enemigo norteño a quien las federadas han de combatir, mano a mano con los soldados, aunque para ello deban arrastrar a sus hijos al campo de batalla. Para militarizar aún más los eventos, recordemos que la inmediata presidenta de la organización—desde su creación hasta su propio fallecimiento — no sería otra que Vilma Espín, esposa de Raúl Castro Ruz. (Cuesta 7)

La época de subordinación al canon machista ha comenzado a ceder y hoy vemos un grupo de mujeres lidiando por un espacio propio donde hacer literatura. Al mismo tiempo_quizás sin proponérselo—adaptan el feminismo norteamericano y europeo para hacer tambalear el monolítico bloque oficialista del arte y la literatura. Las escritoras utilizan un texto resistente referenciado mediante la combinación tradición culta/ melodrama popular la que, dosificada, abre el espacio para que otro orden literario avance. 
En las obras de las nuevas escritoras están presentes diferentes conflictos femeninos como son aquellos provocados por la ausencia del esposo y los hijos, o los propios de las familias marcadas por la emigración, los relacionados con las madres solteras, entre otros muchos problemas característicos de la era postsoviética. Sin embargo, la angustia contemporánea deja fuera héroes y patrones para usar como referente, en cambio, al cubano de a pie. Bárbara Riess expone que los escritores masculinos son propensos a catalogar las representaciones de la mujer cubana en los patrones siguientes:

La abnegada Teresa de Gertrudis Gómez de Avellaneda, la mulata sensual de Cirilo Villaverde, la que canta boleros de Cabrera infante, la madre de José Cemí, de Lezama Lima, la que te mira más de la cuenta, de Edmundo Desnoes, la oportunista, de Severo Sarduy, la virgen adolescente, de Senel Paz, se representa estereotípicamente por medio de la óptica masculina. (cit. en Minjarez Sesma 4)

Resumiendo, la literatura cubana escrita por mujeres no empezó a proliferar hasta los finales de los ochenta y principios de los noventa. Prueba de lo anterior es que entre 1965 y 1979, solo se publicaran en la isla dos novelas firmadas por mujeres (Cuesta 9). El desplome soviético trajo aparejado un descalabro a todos los niveles de la sociedad. De los cambios que vinieron a reflejarse en la narrativa podemos mencionar: el encarecimiento de los productos básicos, la violencia extrema, la aparición de las drogas, el repunte de la prostitución, las comidas sin grasa, los interminables apagones, la ausencia casi total de transporte público, las calles desoladas, la aparición de nuevas jerarquías de clase y de nuevos personajes. Entre estos destaca el friqui, mezcla de joven 
antisocial underground, generalmente asociado con una vida nocturna atiborrada por el alcohol, la marihuana y otras píldoras de diseño (casero principalmente), y amante y practicante de la música heavy metal. El friqui es el joven contestatario por excelencia: tatuado, con piercings, viste con ropas oscuras y botas de cuero negro, y el pelo teñido. Podría considerarse como el equivalente cubano del punk rocker.

Este capítulo analizará la narrativa escrita por mujeres a partir de los noventa, con el fin de mostrar los elementos que se repiten en los discursos de sus representantes. Al respecto, parece apropiado observar los signos de violencia y de humor recurrentes en algunos textos de la época. Solem Minjarez establece certeramente la iniciación del desencanto socio-político con la llegada del "Período especial en tiempos de paz" a principios de los noventa, momento en que Cuba sufre una vez más duras transformaciones que afectarán en consecuencia la producción literaria. El Estado cubano opta por crear el imaginario renovador de una paulatina apertura temática enfocada en la desidealización de la realidad sociopolítica, lográndose con ello el replanteamiento de las distintas caracterizaciones de los personajes femeninos (Minjarez Sesma, Humor, violencia y memoria nacional 2).

Dejar para el final a la escritora Ena Lucía Portela no es un hecho fortuito. A pesar de su juventud, en ella recae la responsabilidad de haber sido la primera creadora en abordar abiertamente el homoerotismo lésbico y ser además pionera de la literatura posnacional en Cuba. A pesar de que la transgresión de sus primeras ficciones ha transitado hacia un lenguaje menos agresivo y coloquial en sus creaciones más recientes, lo que se explica por la ampliación geográfica del espectro de sus lectores, que abarca tanto a Europa como a los Estados Unidos. El nombre de Ena Lucía Portela, afirma 
Saylín Álvarez Oquendo, es "obligada referencia en nuestra literatura contemporánea" y luego agrega con algo de sorna y mucho de verdad: "Portela es apenas una de las figuras más prominentes de las letras cubanas de todos los tiempos, y con esto habrá que conformarse por el momento. . . aunque no suene tan espectacular" ("No me hagas preguntas capciosas"). ${ }^{45}$

Ena Lucia Portela es conocida en el mundo de las letras nacionales desde muy temprano y no precisamente por su adhesión al régimen. Saylín Álvarez, comentando sobre la niñez de la escritora nos relata su aureola de "leyenda negra de niñita desobediente, indisciplinada, anarcosindicalista y con cierta abominable tendencia a la crueldad verbal" ("No me hagas preguntas capciosas"). La propia Ena Lucía, quien ha mantenido desde joven una férrea oposición al régimen, relata como ya era censurada dramáticamente en sus años de estudiante:

También salió a relucir, claro, el asunto de la política. Yo no era propiamente anarquista. ... Pero igual no era comunista, ¡vade retro!, y me vanagloriaba de no serlo, y me la pasaba burlándome del gobierno y haciendo chistes "contrarrevolucionarios". Para más folclor, viajé a los USA como escritora antes de discutir la tesis, me tiré lindas fotos a la entrada de la Casa Blanca y junto a la Campana de la Libertad en Filadelfia, y le traje de regalo una bandera americana a una chiquita de mi grupo que era anexionista. Afoqué demasiado. Entre eso, la carencia de

\footnotetext{
45 Traducida a nueve idiomas y publicada en más de veinte países, la obra de Ena Lucía Portela se estudia ya, entre muchos otros lugares del ámbito académico, en la Universidad de Madison en Wisconsin, en la City University of New York, en la Universidad de California, en la Sorbona, en Leyden, en Gotemburgo, en la Universidad Hebrea de Jerusalén y en la Universidad de Kansas. Las reseñas sobre sus libros han aparecido en periódicos y revistas como Le Monde, Libération, Le Humanité, Le Figaro, Telerama y La Femelle du Requin (De Armas).
} 
"humildad" y el mal de Parkinson que me habían diagnosticado en agosto de 1993 (y que nunca me ha impedido ser moi même en todo mi esplendor), me cerraron las puertas no solo de nuestra Facultad, sino también las de la Casa de las Américas, las del Instituto de Literatura y Lingüística, las de la Fundación Alejo Carpentier y de no sé cuántas instituciones más. (cit. en Álvarez Oquendo, "No me hagas")

Es Ena Lucía Portela la primera escritora cubana en tratar los temas acuciantes de la crisis de los noventa. En la propia voz de Portela leamos las presiones a que se encontró sometida: “Claro que no había ninguna autonomía, ni libertad de cátedra ni la cabeza de un guanajo, pero al menos no te botaban por expresarte como si vivieras en un país libre" (cit. Álvarez Oquendo, "No me hagas"). La subjetividad sexual atrevida y audaz que frecuentemente habitan los textos de Portela como son los que tienen que ver con las primeras experiencias eróticas, el lesbianismo y el homoerotismo, el tráfico sexual, los conflictos de pareja y generacionales, junto con la marginalidad, son a duras penas tolerados por las editoriales oficiales cubanas, la UNEAC o el Ministerio de Cultura.

En 1990, con apenas 18 años irrumpe fuerte Portela con "Dos almas perdidas nadando en una pecera", cuento que para Marielena Olivera Córdova "inaugura el protagonismo lesbiano en la narrativa cubana" (8) y que "es la primera, explícita narración lesbiana de la literatura cubana" (Riccio). En el cuento (nótese que el título es una traducción casi literal de la parte de la canción Wish you were here de Pink Floyd que reza "we're just two lost souls swimming in a fish bowl"), las dos protagonistas, Mónica y la Pelirroja, protagonizan una relación lesbiana sin reconocerlo ni asumirlo, y al final 
una de ellas termina suicidándose. Transgredir los patrones heterosexuales se paga con la vida, como ya vimos pasó con José-María en El ángel de Sodoma de Alfonso Hernández Catá.

Portela redefine la historia en "Sombrío despertar del avestruz", cambiando el trágico final. Aquí las dos jóvenes, que se encuentran en La Habana de principios de los noventa, terminan amándose carnalmente y disfrutando, sin grandes complicaciones. La narradora y protagonista, escritora por más señas y autora del cuento "Dos almas perdidas nadando en una pecera", se describe a sí misma como "delgada, nerviosa, tengo una cara bastante bonita (y vulgar), no soy virgen, ni buena deportista, tengo supersticiones con las arañas, fumo cantidad Y en diciembre cumpliré 20 años" (“Sombrío despertar del avestruz", Nosotras dos 27). La autorreferencialidad con la verdadera Ena Lucía Portela es abrumadora. La narradora pareciera ser un alter ego de la escritora. Ese "borrar las fronteras entre la realidad y la ficción”_ explica Iraida H. López_-, "frecuente en la literatura de Portela, es parte consustancial de su ars poetica" ("Prologo", El viejo, el asesino, yo y otros cuentos xviii).

Transgresor, con una fuerte carga erótica y lúdica, elementos que ayudan a establecer distancia con respecto a la narración, así como mediante la constante referencias a otras obras literarias y culturales, ya sea por alusión, reflexión, citas directas o indirectas, parodia, entre otros recursos intertextuales, este cuento es un buen ejemplo de literatura que entretiene y deleita, y que pide un lector informado, o al menos curioso.

Sin el ánimo de ser exhaustivos se pueden mencionar algunos referentes culturales explícitos que desfilan por el cuento, reales o apócrifos, que recorren desde el mundo contemporáneo hasta el antiguo, desde el histórico hasta el de ficción: Baudelaire, 
Albert Camus, Raymond Raduiguet, Alain Resnais, Marguerite Duras, Pink Floyd, Remington, Norma Jean, Diana de Cabies, Apolo de Belvedere, Safo, Castabula de Sicilia, Isis de los egipcios, Milita de los persas, Astarté de los fenicios, Mini Reina del Cielo de los hebreos, Alillat de los árabes, Diana Febea. Como se aprecia, la literatura y la cultura de todo signo ocupan un lugar central en su obra.

Esta narración, incluida en la antología Nosotras dos sobre literatura homoerótica cubana, publicada en la isla en 2011, hace mención a los lugares de encuentros de los intelectuales y de los que pretenden serlo, que frecuentan la Cinemateca de Cuba, la Casa del Té, "donde solían reunirse ciertos personajes extrovertidos para hablar idioteces desde la apertura hasta el cierre" (28), el Coppelia, etc.

Para López Cabrales, Portela con su literatura abre un diálogo sobre un tema tabú inexistente en las letras cubanas. (80). No obstante, el aparato cultural burocrático mantiene la literatura cubana tan atada al relato cultural nacionalista como antaño, de donde escapa apenas susceptiblemente la literatura homoerótica. Rafael Rojas refiere que a pesar de lo que pueda pensarse, en la isla "no han cesado las condiciones que inducen a seguir formulando un discurso de restitución histórica en torno a la identidad nacional” y agrega que en el último medio siglo los cubanos, tanto dentro como fuera de la isla han vivido "entre la fantasía de haberse adueñado del destino y la angustia de sentirse despojados de un destino" (cit. en Campos 6).

Aun así, las novísimas escritoras, entre las cuales Ena Lucía es pionera, enarbolan el estandarte posnacional con obras donde el homoerotismo, la ingravidez y la individualidad son elementos recurrentes. Esto a pesar de que, como continúa Rojas "los mitos de intransigencia y rechazo a cualquier negociación, como el de la Protesta de 
Baraguá, o el del sacrificio de Martí, la 'revolución inconclusa' y la vuelta del Mesías (Fidel Castro), que reconquistaría la independencia nacional, están muy arraigados en la simbología histórica del orden totalitario" (cit. en Hernández Busto "Entre tumbas y fantasmas").

VII. 1. Biografía. Obras. Reconocimientos

Ena Lucía Portela nace en La Habana, el 19 de diciembre de 1972. Es Licenciada en Lenguas y Literaturas Clásicas por la Universidad de La Habana. Textos suyos (cuentos, ensayos, testimonios, artículos de crítica, fragmentos de novela) han aparecido en diversas antologías, y en revistas y otras publicaciones periódicas, cubanas y extranjeras. A los dieciocho años escribe el cuento "Dos almas perdidas nadando en una pecera", que presenta al XVII Encuentro Debate de Talleres Literarios de la Ciudad de La Habana. Posteriormente este cuento fue insertado junto con "La urna y el nombre (cuento jovial)”, en Los últimos serán los primeros, compilación llevada a cabo por el crítico Salvador Redonet en 1993.

Otro de sus cuentos: "Últimas conquistas de una catapulta fría", se incluye en Doce nudos de un pañuelo, antología también editada por Salvador Redonet en Mérida, México. "Sombrío despertar de un avestruz" fue publicado por la revista Unión No. 22, enero/marzo 1996 y reaparece en la compilación El ánfora del diablo editada por Salvador Redonet, La Habana, Ediciones Extramuros, 1999.

Obtuvo el premio Cirilo Villaverde de la UNEAC (1997) por su novela El pájaro: pincel y tinta china, a la a cual se le dedica un aparte. Dos años más tarde obtiene el premio Juan Rulfo de Radio Francia Internacional por el cuento El viejo, el asesino y yo. 
Premio Jaén (Caja de Ahorros de Granada, 2002) por la novela Cien botellas en una pared, que también obtiene el codiciado Premio Dos Océanos - Grinzane Cavour de la Crítica francesa (2003) a la mejor novela latinoamericana publicada en Francia en dos años. Premio de la crítica cubana (2008) por la novela Djuna y Daniel. Seleccionada en la Feria del Libro de Bogotá entre los 39 escritores más representativos de América Latina menores de 39 años en el 2007.

El norte de la obra de Portela es la literatura, alrededor de la cual giran la mayoría de sus textos. Hay numerosas alusiones a libros y autores de todas las épocas, a las artes plásticas, al cine y a la música. Se trata de una literatura culta, pero accesible; seria y lúdica a la vez. La Cuba de hoy aparece como telón de fondo en la narrativa, mas no de una manera burda o panfletaria. Incluso cuando se da la crítica, esta se pone al servicio de la intención literaria. Ena Lucía Portela, es justo reconocerlo, navega por la cuentística con el velamen un experimentado patrón. Raya la exquisitez en su vocabulario rico y culto.

En el cuento "El viejo, el asesino y yo" (2000), publicado por primera vez en Nuevos narradores cubanos, edición a cargo de Michi Strausfeld en Madrid por la editorial Siruela, y que obtuvo el Primer Premio de Cuento Juan Rulfo de Radio France Internationale en 1999, se manifiesta la importancia primigenia que ocupa la literatura como tema en su universo creador. La autorreferencialidad y la metanarratividad, como se ha mencionado antes, es la marca común entre las ficciones de Portela, Vega Serova y Karla Suárez. Los personajes principales son una joven y un viejo, ambos escritores. A pesar de que los dos tienen sus respectivas parejas, la joven tiene una fuerte atracción hacia el viejo. El trasfondo de la historia se desarrolla en una solitaria Habana que ha 
perdido su encanto y que solo queda en la memoria de aquellos que tuvieron el privilegio de conocer y disfrutar de la algarabía de tiempos mejores: "Que La Habana no es la de antes, los carros, los bares, los olores, la forma de vestir —el amor en La Habana tampoco es el de antes_-" (López "El viejo, el asesino y yo" 63). La narración atrapa, el viejo escritor, centro del conflicto, es codiciado por la chica, pero el joven amante de aquel se interpone impidiendo la concreción del romance. Diálogos precisos, elocuentes, hábiles, llenos de seducciones y pasiones, con un final inesperado que se ha ido construyendo desde las primeras oraciones urdidas a sabiendas por la narradora, perspicaz, irónica y maligna:

Me sacude. Forcejeo. No consigo deshacerme de él. No sé por qué no grito. Alguien tendría que venir. Vivimos en un mundo civilizado, ¿no? No se puede retener a las personas contra su voluntad. ¿Y si gritara? ... Con la mano libre le doy una bofetada.... Me suelta para propinarme la bofetada más grande que haya recibido en mi vida. Tanto es así que pierdo el equilibrio. Con la última frase mis dedos resbalan por el pasamanos. Mármol frío. No hay nada bajo mis pies. Él trata de sujetarme y hay un instante donde se arrepiente. Al menos eso me parece, pues grita mi nombre y, en lugar de "puta", oigo un "Dios mío". Su voz resuena, se multiplica, se fragmenta, viene de muy lejos. Golpes, muchos, incontables, quiebran. Por todas partes. En la espalda y algo se congela. En la cabeza y cómo es posible tanto dolor y de repente nada. Se acabó, final del juego. ¿Era tan fácil? A partir del segundo descanso no soy yo quien rueda por la escalera, es solo mi cuerpo. Dejo de oír. Me siento flotar, algo se hace 
lento. Hay un abismo, un resplandor. Pienso en Amelia. (López, “El viejo, el asesino y yo" 84)

VII. 2. Siempre una extraña entre las piedras. Djuna en Nueva York

$-¿$ No es lo que toman en tu país? -¿En qué país?

-Bueno, pensé que eras de alguno de esos países donde lo toman. ... No me gustaron nada sus preguntas. Yo era extranjero, ¿qué importaba de qué país? José Manuel Prieto (cit. en Newman 45)

En 1999 se publica en La Habana por la Editorial Letras Cubanas el volumen de cuentos Una extraña entre las piedras. El libro está compuesto por seis narraciones que pueden considerarse representativas de la literatura posnacional. Acciones que ocurren en un cementerio de cualquier ciudad; una muchacha voyeurista que se regodea mirando en las noches mientras el joven que le gusta comparte intimidades con un adefesio; las aulas de una universidad que sirven de contexto para discutir sobre la poesía de García Lorca; la obsesión de un fotógrafo con su modelo.

"Una Extraña entre las piedras" es el cuento homónimo que cierra la colección. En él Portela abandona los sofocantes recorridos de la marginalidad cubana y traslada su historia a la ciudad de Nueva York en los años ochenta. El título del cuento es tomado de un verso del poema "Para Ana Veldford" de la cubano-americana Lourdes Casal, quién marchó exiliada a los Estados Unidos en $1962^{46}$. Esta composición, para los que viven,

\footnotetext{
${ }^{46}$ Lourdes Casal (1938-1981) fue fundadora de Areito, revista editada en Nueva York que promovía ensayos y estudios de intelectuales de izquierda (Aime, "Lourdes Casal para nosotros"). Recibió post mortem el premio Casa de las Américas. Casal era lesbiana y de acuerdo con la declaración de Anna Veltfort (alemana que vivió en Cuba en los sesenta y que conoció luego en Nueva York a Casal), "cultivaba una personalidad pública muy ambigua: haciéndose accesible y potable a personas con ideas políticas muy
} 
como vivió ella, una existencia desarraigada, tiene una carga sentimental extraordinaria. A continuación los últimos versos del poema "Para Ana Veldford":

Pero Nueva York no fue la ciudad de mi infancia, no fue aquí que adquirí las primeras certidumbres, no está aquí el rincón de mi primera caída, ni el silbido lacerante que marcaba las noches.

Por eso siempre permaneceré al margen, una extraña entre las piedras, aún bajo el sol amable de despedida de verano, como ya para siempre permaneceré extranjera, aún cuando regrese a la ciudad de mi infancia, cargo esta marginalidad inmune a todos los retornos, demasiado habanera para ser newyorkina, demasiado newyorkina para ser, —aún volver a sercualquier otra cosa. (cit. en Martínez-San Miguel, "En busca de 'Ana Veldford”")

En "Una Extraña entre las piedras" la protagonista lleva por nombre Djuna, como el personaje principal de la novela que luego se estudiará. Djuna es una escritora emigrante, ya mayor, que vive en Nueva York a principios de los noventa y repasa momentos de su vida amorosa con dos mujeres: Sombra y Nepomorrosa. Habla

diversas" (cit. en Martínez-San Miguel). Véase "En busca de la 'Ana Velford' de Lourdes Casal: exilio, sexualidad y cubanía" de Yolanda Martínez-San Miguel. 
“espanglish" con acento, presumiblemente cubano, pero las menciones directas a Cuba son apenas perceptibles: “¿Junto a los escombros de Queens o de La Habana Vieja?”; "para ver si de verdad el Capitolio era idéntico al de la Habana”; “. . p para convertirme, como Andy García y otros compatriotas con gran capacidad de adaptación, en una 'gloria hispana"”(96, 109, 119).

La historia gira alrededor del Clan Campbell, una "barra lésbica" donde Sombra, una afluente profesora universitaria, lesbiana y militante de izquierdas, antigua prosandinista, esnob y prepotente es la líder. En sus manos cae Djuna, que ha dejado su país no por razones políticas ni económicas, sino sencillamente "emigrando, como los pájaros, por razones de clima".

Djuna, que había sido una escritora de bastante éxito, vive, siente, piensa y escribe desde el corazón de Nueva York, protegida por la autoritaria Sombra y con el consuelo de las demás amigas, dentro del clan. Sin embargo, la serie de círculos concéntricos—homosexualidad, etnia, condición femenina—que protegen a la protagonista, al mismo tiempo la aíslan y la marginan de su contexto: entre las piedras de Nueva York será siempre una extraña, entre los brazos de Sombra sentirá siempre su extrañez, así como se ha vuelto extraña para su padre, escandalizado por las preferencias sexuales de su hija, y es extraña también para sus compatriotas a los que la ata solo el tenue hilo del tabaco perfumado que creen fumar "en libertad" (Riccio).

"Una extraña entre las piedras" cambia el alegato con relación a lo previamente escrito por Ena Lucía. La desarticulación del discurso adquiere mayor coherencia que por ejemplo en "Sombrío despertar del avestruz". Se mantiene una narración generosa y áspera. Hay en esta obra un deseo de abrirse a la sociedad, introduciéndose la 
automarginación. "Una extraña entre las piedras" recrea una historia intensamente sensible en el imaginario de la emigración. Los personajes de Portela quieren ser parte de todos los mundos marginales, pero también, sobre todo, quieren pertenecer al mundo. Djuna, escritora, intelectual, esnob, viene a encontrar la felicidad con Nepomorrosa, obrera dominicana en una fábrica de Nueva York, quien le enseñará que todos tenemos nuestro lugar en el mundo donde descansar.

VII. 3. Antes de Djuna en París. Ena en La Habana.

Papá, nativo de Camaguey, de adentro de un tinajón, como él decía, se dedicaba a los devaneos $\mathrm{Z}$ con sus amigotes y sus amiguitos. . . Mamá, nativa de París, se dedicaba a ser nativa de París. ¿Acaso los existencialistas no se dedican a existir? (Cien botellas en una pared 37)

Con El pájaro, pincel y tinta china Portela obtiene en 1997 el premio Cirilo Villaverde de la UNEAC y la beca Fronesis de la Asociación Hermanos Saiz. El jurado [Antón Arrufat, Miguel Mejides y Rogelio Rodríguez Coronel] decidió otorgarle el premio "por la estructuración de un discurso rico, gozoso y creativo; por la densidad cultural que surge a partir de una lograda madeja intertextual que abre espacios semánticos inusitados en la actual narrativa cubana, así como por la concepción de un mundo narrativo en el cual viven personajes construidos con humor y distintos niveles de significación” (Portela, El pájaro, pincel y tinta china. Contra carátula).

Ena Lucía Portela es una escritora de peculiar carácter, que impregna sus creaciones de un marcado y desenfadado erotismo, y que se mueve también con facilidad en un espectro de referencias culturales común en su bibliografía que a veces puede parecer abusiva. Su primera novela, El pájaro: pincel y tinta china (1998), establece 
diversas relaciones con su obra narrativa anterior, a través de lo que la crítica ha denominado un "proceso autofágico en relación con su escritura" (Araujo 30) y que se mantiene también en la posterior. Un ejemplo sobresaliente lo constituye la superposición de sus personajes en situaciones, lugares, épocas y obras reconocidas de la mitología, el séptimo arte, la literatura o la historia, en una madeja que incluye lo grotesco y lo sexual. Tómense dos apartados como muestra. En el capítulo I "Ese loco de rostro renacentista", aparece Fabián, uno de los protagonistas:

Apenas lograba, sin embargo, recordar una época distinta, con olores y sabores menos lacerantes: La Edad de Oro, La belle époque, nuestros años felices.... De naturaleza grandilocuente y por añadidura en los tonos de Séneca o Racine... (11) había conseguido aprender el antiguo dialecto ático, la lengua del Banquete y del teatro clásico, de Tucíbides y Jenofonte. ... En las tres voces griegas tuvo en sus brazos a una criatura deliciosa, más linda que las doradas flores, Cleis mi adoración, aconsejó con vehemencia al joven Cimo..., cantó a Nanno y a los dulces dones de la diosa. . . (12), se deslizaba florentino por las esquinas del quattrocento (13). . . [y] será al final reducido, expiado y condenado en virtud de los preceptos morales y estéticos de Van Dynne (15)....

Siempre (Es casi un decir), quiso bañar a Herminia, diminuta bola de pellejos y olor a molusco podrido dentro de un escaparate. Hubiera deseado visitar a maricones para pedirles amablemente 
que la dejaran por su cuenta (21). ., pero la digna anciana se había horrorizado y le había dicho asqueroso. . . pervertido, mierdero, exhibicionista, lo cual era más bien un contrasentido. . . . Él le había dado una bofetada, una solita para no desencuadernarla. La había empapado con alcohol y se había puesto a jugar con fósforos y confesarle su más recóndita piromanía (22). . . .

No tuvo la suerte de desmayarse en el momento desgarrador de la penetración. .. . Era más fuerte (y más estrecha) de lo que había supuesto. ... Nunca antes había deseado tanto la muerte. Nada podía ser peor que aquel infierno. . . . Silenciosa estuvo llorando durante horas, mientras Fabián, que no se sentía en lo absoluto violador (23). . y pensaba que así se debe desflorar, la secaba suavemente con su enorme toalla verde una vez detenida la hemorragia.

En su capítulo II "Como revolcándose un poco" la maternidad es enunciada de manera bufa, descarnada:

Compasión y asco fue todo lo que expresó el rostro de Fabián.

Sobre todo asco. Tan fatigada y lenta, con los senos hinchados y aquella barriguita de seis meses debajo de algo harapiento. ... Camila se le antojaba, ahora sí, la peor de las cucarachas ¿No decías tú, pedazo de imbécil que necesitabas una mujer en la casa? Pues bien, ahí la tienes. . ¿En qué estabas pensando, 
socoñame? ¿En el peón de la torre, no? Capablanca. El

superajedrecista volador. ¡Agarra ahora tu peoncito! Tu

Fabiancito, gran horror... (34)

Con este libro Lucía Portela ha otorgado ámbito y aliento mayores a ese continuum narrativo, nutrido, ambicioso y logrado corpus de esta década, por el que desfilan y se intersectan personajes que en su mayoría pertenecen a un pequeño mundo intelectual, underground y bastante sórdido, desde el que cínica e intensamente es presentado el entorno social, entre bromas y humor que no perdonan a nadie ni a nada. Novela que persigue hacer pensar y divertir, en la constante búsqueda de la exquisitez. Poética de la narrativa, esa es Ena Lucía Portela.

Con humor coloquial, la anatomía de un doble homicidio, Cien botellas en la pared "aunque parezca aventurado afirmarlo. . . novela negra posmoderna" (I. López, "Prologo" Cien botellas vii) se desenvuelve en La Habana de los noventa y sigue las peripecias de Zeta y de su amiga Linda ambas escritoras (la primera aficionada y la segunda escritora profesional) de thrillers, quienes nos adentran en el ámbito marginal de la ciudad, ese que no aparece en las guías para turistas. A diferencia de otros textos de la última década del pasado siglo, donde se desmitifican "los logros" de la Revolución de modo casi documental o hace gala el realismo sucio, Cien botellas en una pared prefiere derribar esa concepción de una manera desenfadada, con un una buena dosis humor y ostentando al mismo tiempo el amplio diapasón escritural de la autora, que va aprovecha desde las locuciones coloquiales y dichos populares hasta los juegos intertextuales. A continuación un fragmento del capítulo 1 que lo ejemplifica: 
No se le ocultaba el lado absurdo y hasta ridículo de su ira. Sabía que todos aquellos bellacos, miserables, imbéciles, fucking bastards, jamás conseguirían hacerle tragar ni el más diminuto de sus embelecos. Les faltaba astucia, chispa, mundo. Les faltaba clase. Les faltaba todo lo que él tenía de sobra, hasta para regalar, para hacer dulce. ¿Pero qué se habían pensado, eh? ¿Que él había nacido ayer? ¿Que era un parvulito, un chama del círculo infantil? ¿Que podían embaucarlo así tan fácil? Qué atrevidos, los malditos....

En más de una ocasión había intentado estrangular a su terapeuta, pero sin demasiado éxito. Por suerte, nunca se decidió a portar armas. Se limitaba a soñar con un rifle, con una Asociación Nacional del Rifle de la que él sería presidente y máximo energúmeno. Porque ellos, los sinvergüenzas, no lo dejaban tranquilo. Ellos insistían, reiteraban, porfiaban hasta el infinito con una calma asquerosa. Y aún se atrevían a mirarlo con sorna, tan campantes, los muy hijos de mala madre, con sus ojuelos cínicos....

Había que andar a cien ojos. Porque si los dejaba salirse con la suya aunque fuera una sola vez, una solita, lo más probable era que intentaran hacerle creer nuevas mentiras más insolentes aún que las anteriores, más apestosas, más hediondas. Y luego otras y otras y otras... La historia de nunca acabar. ¡Y a él sí que no lo 
cogían pa’eso! Qué va. Él tenía sus estrategias. Como decían los antiguos romanos: si vis pacem, para bellum....

Mientras, yo debía dejarme de tanta lloradera y tanto artistaje, levantarme de una buena vez antes que él me levantara de un sopapo o me arrastrara por los pelos e ir al antro de los bajos (en la primera planta de la Esquina del Martillo Alegre hay un bar clandestino, el de Pancholo Quincatrece, socito mío, donde también se puede conseguir marihuana; yo vivo en los altos) a comprar un litro, ah, y cigarros (cuando estaba muy furioso, hecho una fiera, el moñito solía fumarse dos a un tiempo, agarraba uno en cada mano y los absorbía de manera alterna), porque no había en el mundo todo panorama tan indecente como el de una gorda subnormal y despatarrada en el suelo, con el rímel corrido, llorando lágrimas negras y haciéndose la víctima, la dama de las camelias. ¡Mira que yo le había salido trágica! Ni que fuera Greta Garbo. (11-15)

La eficacia con que la escritora expone la narrativa y la excelencia de las situaciones, convergen para conservar el abismo, narrarlo con todo detalle.

VII. 4. Adiós a la nación. El desplazamiento del imaginario

Porque a Ena Lucía Portela le importan sobre todo las palabras, la poesía de las palabras, y, por supuesto, el intento soberbio de llegar con ella lo más cerca posible de la perfección. Abilio Estévez (Djuna y Daniel, contraportada) 
Escritas en un lenguaje coloquial, sin dejar de ser más o menos estilizado según el caso, las anteriores novelas de Portela, a saber, El pájaro: pincel y tinta china (1999), La sombra del caminante (2001) y Cien botellas en una pared (2002) están ambientadas en Cuba y en el presente inmediato. Todo eso cambia con Djuna y Daniel, cuya primera edición se publica en Cuba en 2007.

En esta entrega, donde se pierde la referencia a la mayor de las Antillas y los personajes deambulan en escenarios de Europa y los Estados Unidos tan variados como París, Londres, Berlín, Múnich, Viena, Ámsterdam, Budapest, San Francisco y Nueva York, también faltan el barroquismo y los juegos verbales localistas de aquellas novelas anteriores y de los cuentos portelianos. Ahora el estilo se aligera considerablemente, el español se vuelve más estándar, y faltan también las abundantes alusiones literarias y culturales por la que es reconocida su prosa. La ensayista Yarelis Cabrera pregunta retóricamente: “¿Importa esto, cuándo una obra así va a ser traducida a no sé cuantos idiomas? Y justifica esa disminución en el rigor de su escritura cuando asevera "la autora exacerba como nunca su punto de vista universal", lo que implica el querer llegar a muchos más lectores (Cabrera, "Djuna Barnes resucita en una novela cubana").

Ya en 1997, en su libro El pájaro: pincel y tinta china, había evocado a quien diez años más tarde tomaría el papel protagónico de Djuna y Daniel: Djuna Barnes. En 1999 repite con Una extraña entre las piedras, cuento en el cual el personaje principal, escritora cubana emigrante que vive en Nueva York en los ochenta, lleva por nombre Djuna, y además se refiere a "la otra" Djuna Barnes durante todo el relato: "El espejo del baño, último y fatigado espacio de los circuitos interiores, no solo era testigo, sino también cómplice de sus mejores incertidumbres. El espejo era capaz de provocar 
espasmos, mortales contracciones, como diría Djuna Barnes" (El pájaro, pincel y tinta china 13).

Ahora, en una vuelta de 180 grados, Portela se aventura por nuevos rumbos y presenta una novela histórica posmoderna y posnacional que tiene como escenario la época transcurrida entre la Primera y Segunda Guerras Mundiales. En Djuna y Daniel, somos transportados a la vieja Europa [París, Londres, Múnich, Viena, Ámsterdam, Budapest] y a América [Nueva York, San Francisco] mezclando incidentes reales y ficticios de la vida de la legendaria Djuna Barnes y el anómalo Daniel Mahoney. Djuna y Daniel se alzó con el Premio de la Crítica cubana en el 2008, en una acertada comedia con algo de melodrama, agraciada y trivial. Posmodernismo cosmopolita donde las locuciones coloquiales, los dichos populares y los juegos intertextuales comunes en su literatura — Cuba como país incluso—pasan inadvertidos. La misma autora se refiere a este abandono del país de este modo:

Djuna y Daniel tiene que ver con Cuba solo en el sentido de que, en última instancia, en este mundo globalizado todo tiene que ver con todo. Por lo demás, no hay personajes cubanos en esta novela, ni referencias a la Isla, ni alusiones al clima tórrido, el subdesarrollo agobiante y el dictador decrépito; en sus casi 350 cuartillas no aparece ni una sola vez la palabra Cuba. Se comprenderá que en modo alguno procedía que Djuna, Dan, Thelma Wood, León Meir, Emily Coleman, el gordo Jean-Luc, Henriette Met-mierda, el padre Sean, Bobby McAlmon, Joyce, Charles Imposible, Peggy Guggenheim y el resto de la tribu, 
hablaran como la gente de mi barrio acá en La Habana. Debía yo, pues, emplear un lenguaje muy distinto al que había manejado hasta entonces, no solo en las novelas, sino también, dicho sea de paso, en los cuentos, y hasta en los ensayos y artículos. Debía escribir en español. ¡Ay de mí! (Portela, “Algunos rumores sobre Djuna y Daniel")

Aquí, en esta quizás la más posnacional de todas las obras nacionales, la habitual y siempre eficaz habla coloquial con que Portela logra sus transgresores tonos se trasmuta en un castellano más plano, sin el abuso de tintes o jerga nativa, aspectos que le dan a la historia un perfil internacional. Pero tampoco debemos creer a pies juntillas esa declaración de la autora de poner a los personajes del libro a "hablar español" en contraposición del lenguaje de "la gente de mi barrio acá en la Habana". A veces se le escapan expresiones típicas del idiolecto cubano. Y sobre todo cuando estas expresiones sirven para ofender o expresar estados de ánimo. Repasemos algunas de ellas al azar: “¡Me cago en tu madre, maricón...!, o algo por el estilo, en francés” (15); “iNanay!” (17); “¡Cara de croqueta!”; “Oye, tú, cara de culo” (27); "él no era loco ni pintoresco ni un cojón" (32); "nunca ha podido salir así de una curda" (32); "Le pegaba la gorra a todos sus conocidos" (41).

En Djuna y Daniel, obra universal sin dudas, Ena Lucía ha planeado cada diálogo, situación, actores, recursos y lenguaje de forma tal que el imaginario de la nación se esfuma en aras de una Djuna Barnes creíble. La recreación de Portela le debe 
mucho a la obra académica del biógrafo Phillip Herring y sirvió como base para hacerla creíble:

Lo cierto es que Mahoney estaba acumulando resentimiento por la descripción que se hacía de él en la novela. El orgullo que pudiera haber sentido cuando se publicó se evaporó al parecer en determinado momento, quizá porque uno de sus amigos, a quien había insultado, compró muchos ejemplares, marcó los pasajes poco halagadores para él y los repartió por el barrio. Mahoney se presentó una noche furioso en el piso de Djuna a la una y cuarto de la madrugada y estuvo amenazándola hasta las cinco. (Herring, Djuna Barnes 215)

Djuna y Daniel redactada por una escritora de experiencia en el buen hacer, es amena y eficaz, y entrelaza una amalgama de eventos reales e imaginarios en la vida de la legendaria Djuna Barnes. Djuna y Mahoney van por París entre todo lo que a alcohol huela, unas veces atacándose, otras apoyándose. La raíz argumental de la obra es la amistad, aunque temas como la dipsomanía, el destierro y las intimidades también se encuentran presentes.

En el París bohemio de los veinte, el de la Generación perdida, Daniel A. Mahoney, norteamericano de origen irlandés que "después de mucho vagabundear por dos continentes, resolvió quedarse en París" (Djuna y Daniel 11), colérico tras descubrir que el personaje O'Connor de Nightwood (El bosque de la noche) toma como base sus propias vivencias, acude en medio de la madrugada a pedir cuentas a su amiga Djuna Barnes, a quien intenta sacar de su sueño etílico en el apartamento de la Rue Saint- 
Romain. A partir de esta escena que entreteje la narración se suceden los saltos temporales mediante los cuales Portela traza el retrato de una generación que se perdió.

Tomando como base la biografía de Philippe Herring sobre Djuna Barnes, Portela se adentra en el Quartier Latin y desvela en una bien hilvanada y desenfadada metaficción la amistad que unió a Djuna con Dan Mahoney “faiseur d'anges, gozoso y fatídico, homosexual y clown”. Blanca Riestra comenta así la obra: “Aunque el proyecto es ambicioso, la escritura adecuada y los personajes están tratados con convicción y con cariño. .., el lector hubiese deseado mayor osadía por parte de Portela. Aquellos personajes que Barnes había hecho incandescentes, metafísicos, profundamente oscuros, quedan desgraciadamente desvelados por una aproximación demasiado de facto" ("La tormenta en un vaso").

VII. 5. La formidable Barnes. El bosque de la noche

La mujer que se presenta al espectador al espectador como un "cuadro" compuesto y acabado es, para la mente contemplativa, el mayor de los peligros. Djuna Barnes (El bosque de la noche 29)

Djuna Barnes, escritora de culto prácticamente desconocida, fue un personaje fascinante y contradictorio. Amiga de Joyce, protegida de Peggy Guggenheim, célebre belleza de la Rive Gauche, fotografiada por Man Ray, se eclipsó a edad temprana, y se recluyó en Greenwich Village hasta su muerte en 1982, a la edad de 90 años, víctima del alcoholismo, escribiendo poemas que tiraba por el suelo y cultivando una merecida fama de excéntrica. Había nacido en Nueva York el 12 de junio de 1892 en el seno de una familia con intereses artísticos. 
Después de una infancia tormentosa, estudió arte, fue periodista e ilustradora, formó parte de la bohemia del Greenwich Village neoyorkino -Eugene O’Neill, Gertrude Stein_-, pero fue en el París de la década del veinte en donde se asentó junto a su amante, la escultora Thelma Wood, y vivió su esplendor como artista y mujer. Había sido enviada por Harper's Magazine para escribir un reportaje acerca de los vanguardistas y allí se convirtió en uno de ellos (Alonso). Andrew Field recogió en su biografía no autorizada sobre Djuna Barnes que ella misma había expresado: "No soy lesbiana. Simplemente amé a Thelma”. De hecho tuvo numerosos amantes masculinos e incluso un embarazo abortado. Field sostiene que la falta de hijos es uno de los temas recurrentes en la obra de Barnes y no tenerlos un dogma profundamente asumido por la creencia de que la carne es en sí misma esencialmente perversa y debe ser resistida. Su tío abuelo Thomas Cushman Buddington, uno de los muchos espiritualistas de la familia, publicó en 1886 un libro que trataba de Julián el Apóstata y de las relaciones entre el paganismo y el cristianismo. Zadel Barnes, la abuela de Djuna, descendía de tres hermanos Barnes que a principios del siglo XVII se trasladaron a los Estados Unidos procedentes de Inglaterra.

Djuna Barnes nunca fue a la escuela ni a ninguna otra institución educativa. Siendo aún adolescente empezó a colaborar con diversas publicaciones neoyorquinas escribiendo artículos, columnas o reportajes que ella misma ilustraba. Su abuela Zadel fue una figura clave en su educación. Hanna O. Semicz explica lo siguiente sobre las dificultades que enfrentó El bosque de la noche antes de su publicación:

Cuando regresó a Nueva York, Djuna Barnes empezó a presentar su novela a los editores. El manuscrito no sufrió las consabidas demoras sino 
que entraba y salía de los despachos "como expulsado por una engrasada puerta giratoria de una película muda". Pero la novela había ganado fervientes admiradores antes de llegar a imprenta: Dylan Thomas, Edwin Muir y T.S. Eliot. Un joven editor de Faber ya había rechazado el manuscrito por sus temas y sus posibilidades comerciales.

Barnes había escrito 190.000 palabras que redujo a 65.000. Cuando al fin la novela fue aprobada, Eliot dijo que quisiera reducirla más aún. Pero su más notable aportación fue el título: de Anatomy of the Night pasó a Nigthwood. Djuna lo aceptó de buen grado. El título contenía la involuntaria marca secreta de Thelma (El bosque de la noche). Además wod significa locura en inglés antiguo [Wood era también el apellido de Thelma]. . . Después Eliot escribió el consabido prólogo y la novela salió al aire. El bosque de la noche recibió críticas favorables pero no se vendió. Oscura, difícil, retrato decadente de un mundo en crisis, lésbica, isabelina, art deco construida con un propósito trágico, piedra angular de su tiempo. Fue evidentemente incomprendida. (Semicz 1-5)

Roman à clef que tiene mucho de autobiografía, todos los personajes se identifican con personas cercanos a la escritora. Ella misma es Nora Flood, la protagonista, sobre lo cual T.S. Eliot afirmó en el prólogo que escribió para la primera edición de la obra en 1936: "Djuna Barnes ha descubierto su propio dolor, lo ha identificado y le ha dado una palmada en el hombro" (cit. en Cabrera, "Djuna Barnes resucita en una novela cubana"). En Djuna y Daniel, el posnacionalismo cosmopolita puede palparse. Desde la argumentación hasta los recursos narrativos empleados, la mano 
firme de Portela acerca a Djuna Barnes a una segunda oportunidad de ser mundialmente conocida.

VII. 6. Conclusiones parciales

Son dos conocidos o conocidas, dos neutros en fin - "neutro" no significa "homosexual", significa precisamente, "neutro", no vayas a confundirte. Ena Lucía Portela (El pájaro, pincel y tinta china 141)

Ante la desventura, los aprietos económicos y las privaciones materiales de todo tipo que se acrecentaron en la isla a partir de los años noventa las escritorasespecialmente las novísimas - utilizan el humor y los conflictos ficcionales como herramienta de resistencia. López Cabrales lo define de esta manera: "Reconfigurar unos sujetos femeninos transgresores que se niegan a hundirse en los momentos de crisis" (López Cabrales 104). Poco a poco, escrito tras escrito, en la medida en que se amplía el círculo de lectores, el complejo, rico, grotesco y transgresor estilo de Portela se aligera. El barroquismo de El pájaro: pincel y tinta china y Cien botellas en una pared se ha disipado cuando llega Djuna y Daniel. Los juegos verbales locales y el lenguaje coloquial cubano, y particularmente "habanero" (asunto de nula importancia para el mercado internacional) pierden juego y ceden paso a un castellano más neutro.

A pesar de ese cambio de estrategia escritural, no hay que olvidar que estamos en presencia de la primera literata que expresó abiertamente la experiencia lésbica en la literatura cubana, ya no tan solo como homoerotismo, sino en un campo más extenso, que como recuerda Madeline Cámara incluye "los enfrentamientos generacionales, la iniciación sexual, el homoerotismo, los conflictos con la pareja, las actitudes de 
marginación social voluntaria o involuntaria, los friquis y las “jineteras”' (cit. en López Cabrales 75-6.).

La lectura y apreciación de la obra de Ena Lucía Portela no acepta medias tintas. Uno puede llegar a apasionarse o a repeler sus anécdotas, ambientes y hasta la tan llevada y traída verbosidad de un narrador evocativo y en ocasiones presuntuoso. Puede, incluso, sorprenderse de hacia dónde van a parar algunos de sus personajes, de cuya existencia real y cultural en La Habana de hoy a muchos no les queda duda de que la autora ha representado fielmente en sus obras (práctica considerada desleal por algunos y para otros solo licencia, pasatiempo paródico). Pero hay que admirar el tono de una espléndida prosa imaginativa en la que no se pierde de vista la sintonía de las formas. 


\section{CONCLUSION}

Presentar y comentar, en tan breve espacio, los desafiantes nuevos contornos literarios del posnacionalismo en la narrativa cubana actual, ha requerido establecer un intercambio con la historia de la literatura cubana, desde el siglo XIX hasta la actualidad, revelando su contribución a la compleja, industriosa y beligerante constitución y resistencia del orden social.

El fracaso del socialismo y el descrédito de las grandes utopías que empieza desde principios de los noventa, han influido en la manera en que los escritores (en especial los nacidos a partir de 1960) desarrollan su obra: a diferencia de sus predecesores, ninguno de ellos se muestra obsesionado por la identidad latinoamericana. Se reivindica el derecho de los creadores latinoamericanos a escribir novelas que pasan en todos los espacios y lugares, o que no tienen ni espacio ni lugar preciso, abandonando frecuentemente toda referencia a América Latina.

El posnacionalismo cubano se inserta dentro de esta corriente. Los nuevos narradores eluden el compromiso político militante, evitan los mensajes altruistas o las moralejas ejemplarizantes. Se produce un abandono total de las pretensiones de definir posiciones con relación al futuro de la patria o a su propia identidad. Esto no significa necesariamente que la nación desaparezca siempre como escenario, sino que se distingue a través de una mirada posnacional, es decir, desprovista de una identidad fija y alejada de ideologías preestablecidas. La identidad nacional y sus fronteras ya no constriñen ni limitan al escritor. El embrión de un nuevo imaginario logra asirse a un tema recurrente: 
la diversidad cuyos patrones se basen en discursos monológicos es ya una quimera. El nacionalismo, especialmente el autoritario y excluyente, tiene sus días contados.

A pesar de la preponderancia del nacionalismo afirmativo, ha existido asimismo en el pensamiento de la isla otra variante de nacionalismo, menospreciada por los que controlan la difusión de la cultura y las ideas. Este discurso alternativo tiene como principal rasgo su visión irónica y desconfiada de los grandes relatos que forman la nación. Sus representantes han adquirido en la actualidad la mayoría de los espacios literarios en lo que se podría considerar un discurso posnacional. Es decir, una manera diferente de acercarse a la nación. Esta corriente se inserta en el posnacionalismo en cuanto sitúa sus historias fuera de la isla, ya sea en un lugar geográfico enunciado que no es Cuba, o en sitio deliberadamente impreciso que al no constreñirse en los límites de la isla, ya sean ideológicos, históricos, económicos, etc., libera las manos y mentes de esas escritoras para tratar cualquier tema, sortear la censura, el miedo o los prejuicios. Esta narrativa construye sus ficciones sostenidamente fuera de la época revolucionaria. La Revolución que fuera tema obligado, marco obligado, referencia obligada desaparece en estas obras, sin importar cuán profunda haya sido su impronta. El posnacionalismo cubano intencionalmente se desidentifica no solo de la geografía si no sobre todo de la historia revolucionaria y eso lo distingue y singulariza.

Escritores olvidados, obviados o desplazados porque se consideraban no productivos ideológicamente para el proyecto Estado-Nación no solo resucitan, sino que pasan a ocupar lugares privilegiados en el canon cubensis, a la par que se produce un fenómeno consistente en desmitificar y humanizar a escritores canónicos históricos. 
En Cuba, con la crisis económica se produce una revelación de la narrativa femenina que a finales de siglo se ha convertido en una de las marcas de la literatura nacional de hoy. Académicas, escritoras y artistas en general se organizan e intervienen con sus prácticas profesionales en la vida cultural, específicamente en la vida literaria del país, y refuerzan por esta vía su presencia y participación, tan necesaria en momentos de crisis e incertidumbres.

El uso desprejuiciado del cuerpo por parte de las nuevas narradoras, constituye un signo recurrente en sus textos, donde el disfrute sexual femenino ya no es un tema tabú. La descripción del acto sexual y del cuerpo, su uso como centro temático, la presencia de modelos de sexualidad no convencionales como el sadomasoquismo y el homoerotismo, conducen a pensar en una mujer que va superando las limitaciones en torno a su sexualidad. El erotismo, un íntimo discurso en marcado contraste con la dimensión social, resquebraja el concepto de nación y de Estado y su hasta ahora irreprochable carácter unitario.

La existencia de un discurso que parte desde el género para dar cuenta de la identidad y la diferencia femeninas, manifiesta un tránsito a favor de una identidad posicional en las mujeres, la cual no responde a criterios estáticos, sino que se caracteriza por su diversidad y sugiere una concepción más abierta de lo que significa ser mujer, entendida como una circunstancia a la que corresponden valores históricos, culturales, simbólicos y, en especial, que parte de las experiencias de cada ser humano.

En Vega Serova, Karla Suárez y Ena Lucía, la totalidad de su quehacer literario gira en torno a la sexualidad, con un marcado énfasis en el discurso homosexual. La homosexualidad rechaza la ideología homogénea y normativa, reivindicando su sentido 
emancipador. Estas tres autoras se expresan mediante un lenguaje agresivo de gran impacto emocional. Sus textos evocan mujeres sexualmente diversas, enamoradas, confundidas, que no pueden soportar el envejecimiento y que evocan un pasado y lo rememoran; mujeres que, a pesar de todo, son capaces de afrontar sus respectivas realidades y avanzar.

La narrativa de estas escritoras contiene una serie de rasgos comunes. La transgresión de los estereotipos de género y de los comportamientos heteronormativos se convierten en un instrumento de dinámica posmoderna que presenta nuevos códigos y supone un desafío a las perspectivas tradicionales. Otro tema que emerge en los textos de estas autoras es el de la reflexión sobre el oficio de escribir y el mundo de las letras, un énfasis antes inexistente, lo que al margen de otras consideraciones, sin duda subraya la importancia adquirida para ellas, en tanto mujeres, de un espacio al mismo tiempo de riesgo y libertad, de indagación íntima y realización personal, de búsqueda formal y proyección pública, de aceptación o rechazo de patrones y autoridades establecidos.

Como hemos podido ver, en la obra de las autoras más recientes de la narrativa cubana hay una aceleración de esa tendencia que ya describiera Octavio Paz años atrás: "la carrera hacia el tiempo perdido, la búsqueda frenética del presente, el furor de ser contemporáneos de todos los hombres" (El laberinto de la soledad 235). El posnacionalismo lucha por la necesidad de acceder a la temporalidad para obtener una consagración concreta de permanencia y deberá animarse a penetrar el tiempo literario como "única promesa de salvación artística" (Casanova 127). 


\section{OBRAS CITADAS}

Aguado, Ladislao. "Polvo en el viento". Opinión. Archivo Work in Progress. www.inworkprogress.wordpress.com 10 dic. 2010. Digital. Fecha de acceso 23 feb. 2014.

Águila, Rafael de. “¿Pathos o Marketing?”. El Caimán Barbudo. 31.292 (1998): 2-3. Impreso.

Aguirre, Mirta. "Poesía y cubanía". Estudios literarios. La Habana: Letras cubanas, 1981: 43-78. Impreso.

Aime. "Lourdes Casal para nosotros". Havana Times 21 nov. 2013. www.havanatimes.org. Digital. Fecha de acceso 5 may. 2014.

Aínsa, Fernando. "La reescritura de la historia en la nueva narrativa latinoamericana". Cuadernos Americanos 4-28 (julio-agosto 1991): 13-31. Impreso.

---. "Palabras nómadas: Los nuevos centros de la periferia". Alpha (Osorno) 30 (julio 2010): 55-78. Impreso.

Alonso, Odette. "Djuna Barnes, los ojos de la noche”. Sáficas 26 sep. 2008. www.saficas.blogspot.com. Digital. Fecha de acceso 3 abr. 2014.

Álvarez Álvarez, Luís. "En torno al poeta Virgilio Piñera”. www.cubaliteraria.com. 4 de may. 2012. Digital. Fecha de acceso 17 dic. 2013.

Álvarez-Borland, Isabel. "El silencio del hambre: figuras de la carencia en Antonio José Ponte". Hispania 90.3 (2007): 443-52. Impreso.

Álvarez, Imeldo. La novela cubana en el siglo XX. La Habana: Letras cubanas, 1980. Impreso.

Álvarez, Inmaculada. "El discurso sexual como valor de identidad nacional de lo cubano". Revista de Humanidades: Tecnológico de Monterrey 14 (2003):13-36. Impreso.

Álvarez Oquendo, Saylín. "No me hagas preguntas capciosas. Conspirando con Ena Lucía Portela”. Otro Lunes. Revista Hispanoamericana de Cultura 27 (2013). www.otrolunes.com. May. 2013. Digital. Fecha de acceso 14 de feb. 2014.

Anderson, Benedict: Comunidades imaginadas. Reflexiones sobre el origen y la difusión del nacionalismo. México: Fondo de cultura económica, 2006. Impreso. 
Appadurai, Arjun. La modernidad desbordada: dimensiones culturales de la modernización. Buenos Aires: Trilce, 2001. Impreso.

Arciniegas, Germán, ed. "Nuestra América es un ensayo". Latinoamérica. Cuadernos de cultura latinoamericana 53 (1979): 5-17. Impreso.

Arcos, Jorge Luis. Desde el Légamo. Ensayos sobre pensamiento poético. Madrid: Colibrí, 2007. Impreso.

---. et al., Historia de la Literatura Cubana. La colonia: desde los origenes hasta 1898. Tomo I. La Habana: Letras Cubanas, 2002. Impreso.

---. et al., Historia de la Literatura Cubana. La Revolución (1959-1988). Con un apéndice sobre la literatura de los años noventa. Tomo III. La Habana: Letras Cubanas, 2008. Impreso.

---. "Notas sobre el canon (Introducción a un texto infinito sobre el canon poético cubano)". Desde el Légamo. Ensayos sobre pensamiento poético. Madrid: Colibrí, 2007. 33-46. Impreso.

---. Las palabras son islas. Panorama de la poesía cubana del siglo XX. (Ed., introducción, selección y notas). La Habana: Letras Cubanas, 1999. Impreso.

Arenas, Reinaldo. "La isla en peso con todas sus cucarachas". Virgilio Piñera: La memoria del cuerpo. Ed. Rita Molinero. Madrid: Plaza Mayor, 2002. Impreso.

---. Antes que anochezca. Barcelona: Tusquets, 1992. Impreso.

---. Celestino antes del alba. Barcelona: Tusquets, 2000. Impreso.

Armas Marcelo, J.J. "Mundo literario: Prólogo a La Habana para un infante difunto". Artesanías literarias. www.artesanosliterarios.blogspost.com. 15 feb. 2010. Digital. Fecha de acceso 13 mar. 2014.

Armengol, Alejandro. "Relatos de un cubano, que no habla de Cuba". armengol.blogspot.com, 2009. Digital. Fecha de acceso 11 oct. 2014.

Aseguinolaza, Fernando Cabo y María do Cebredo Rábade Villar. Manual de Teoría de la Literatura. Madrid: Castalia Universidad. 2006. Impreso.

Barquet, Jesús J. Consagración de la Habana: las peculiaridades del grupo Orígenes en el proceso cultural cubano. Miami: Iberian Studies Institute, 1992. Impreso.

---. Teatro y revolución cubana. Subversión y utopía en Los siete contra Tebas de Antón Arrufat. New York: The Edwin Mellen Press, 2000. Impreso. 
Bejel, Emilio. "Sexualidad carcelaria en Hombres sin mujer, de Carlos Montenegro". ALEC 31.1 (2006): 269-86. Impreso.

Blanchot, Maurice. El espacio literario. Madrid: Editora Nacional, 2002. Impreso.

Blackmore, Susan. La máquina de Memes. Oxford: University Press, 1999. Impreso.

Bobes, Marilyn. "El homosexualismo en la literatura cubana. Algunas aproximaciones a un tema tabú". www.lajiribilla.cu. Ene. (2002). Digital. Fecha de acceso 23 ene. 2014.

---. "Todos los demonios de Anna Lidia Vega Serova". La letra del escriba. http://www.cubaliteraria.cu/revista/laletradelescriba/n74/index.html. Noviembre 2008. Digital. Fecha de acceso 14 ene. 2014.

Bobes, Velia Cecilia. La nación inconclusa. (Re)constituciones de la ciudadanía y la identidad nacional de Cuba. México: Flacso, 2007. Impreso.

Boloña, José Severino. Colección de poesías arreglada por un aficionado a las musas. 2 t. Habana: Oficina de José Boloña, 1833. play.google.com. Digital. Fecha de acceso 12 feb. 2014.

Buckwalter-Arias, James. "Reinscribing the Aesthetic: Cuban Narrative and Post-Soviet Cultural Politics". PMLA 120.2 (2005): 362-74. Impreso.

Bueno, Salvador, ed. Costumbristas cubanos del siglo XIX. Caracas: Ediciones Ayacucho, 1985. Impreso.

---. Ed. Cuentos y noveletas. Alfonso Hernández Catá. La Habana: Letras cubanas, 1983. Impreso.

Cabrera, Yarelis. "Djuna Barnes resucita en una novela cubana". Cubarte 21 ene. 2009. www.cubarte.cult.cu. Digital. Fecha de acceso 14 abr. 2014.

Camayd-Freixas, Erik. Etnografia imaginaria. Historia y parodia en la literatura hispanoamericana. Guatemala: F\&G Editores, 2012. Impreso.

Calderón, Damaris: Duro de roer. Habana: Ediciones Unión. 2005. Impreso.

---. "Virgilio Piñera: una poética para los años 80". www.fflch.usp.br.virgilio. Digital. Fecha de acceso 16 feb. 2014.

Campos, Julieta. “Convivio antillano”. Letras libres (nov. 2000): 96-7. Impreso. 
---. "Un banquete canónico, de Rafael Rojas". Letras libres (nov. 2000).

(http://www.letraslibres.com/revista/libros/un-banquete-canonico-de-rafaelrojas). Digital. Fecha de acceso 3 feb. 2014.

Campuzano, Luisa. Las muchachas de La Habana no tienen temor de Dios... Escritoras cubanas (S. XVIII-XXI). La Habana: Unión, 2004. Impreso.

---. "La mujer en la narrativa de la Revolución: ponencia sobre una carencia".Quirón o del ensayo y otros eventos La Habana: Letras Cubanas, 1988. Impreso: 66-104.

---. Narciso y Eco: Tradición Clásica y Literatura Latinoamericana. Buenos Aires: La Bohemia, 2006. Impreso.

---. "Narradoras cubanas de hoy: un mapa de bolsillo". La isla en peso 4. www.uneac.org.cu. Digital. Fecha de acceso 3 abr. 2014.

Cantizano Pérez, Félix. "Eros prohibido: transgresiones femeninas en la literatura española anterior al siglo XVIII". AnMal Electrónica 32 (2012). www.anmal.uma.es. Digital. Fecha de acceso 24 jun. 2013.

Careaga, Roberto. "Cuba edita obra de Padilla, símbolo de la censura castrista". La Tercera 20 feb. de 2013. www.latercera.com. Digital. Fecha de acceso 17 ene. 2014.

Cárdenas y Rodríguez, José María: La literatura costumbrista cubana de los siglos XVIII y XIX. IV. Los escritores. La Habana, Oficina del Historiador de la Ciudad de La Habana, 1962: 101-8. Impreso.

Carrington, Dulce María Sotolongo. Nosotras dos. La Habana: Ediciones Unión, 2011. Impreso.

Carrión, Miguel de. Las honradas. Biblioteca Nacional de Cuba. www.bdigital.bnjm.cu. Digital. Fecha de acceso 5 mar. 2014.

---. Las impuras. La Habana: Organización Continental de los Festivales del Libro, 1959. Impreso.

Casanova, Pascale: La república mundial de las letras. Barcelona: Anagrama, 2001. Impreso.

Casal, Julián del. Páginas de vida. Poesía y prosa. Caracas: Biblioteca Ayacucho, 2007. Impreso.

---. Julián del Casal. Poesía completa y prosa selecta. Ed. Álvaro Salvador. Madrid: Verbum, 2001. Impreso. 
---. Julián del Casal. Prosas 1. La Habana: Consejo Nacional de Cultura, 1963. Impreso.

Castany Prado, Bernat. Literatura Postnacional: Latinoamérica. Un estudio de caso. Dis. Georgetown University, 2006. Washington DC: UMI, 2007. 3247345. Impreso.

Castro Ruz, Fidel. "Discurso pronunciado en el campamento Ignacio Agramonte, en Camagüey, el 21 de octubre de 1959". www.cuba.cu. Digital. Fecha de acceso 25 nov. 2013.

---. "Discurso pronunciado en la clausura del Primer Congreso Nacional de Educación y Cultura, efectuado en el teatro de la CTC, en La Habana, el 30 de abril de 1971". www.cuba.cu. Digital. Fecha de acceso 25 nov. 2013.

---. "Discurso pronunciado en la clausura del XVI Congreso de la CTC, en La Habana, celebrado en el teatro "Carlos Marx", el 28 de enero de 1990". www.cuba.cu. Digital. Fecha de acceso 25 nov. 2013.

---. "Discurso pronunciado en la clausura de la sesión diferida del Tercer Congreso del Partido Comunista de Cuba, celebrado en el teatro "Carlos Marx", el 2 de diciembre de 1986". www.cuba.cu. Digital. Fecha de acceso 25 nov. 2013.

---. "Discurso pronunciado en La Demajagua, Manzanillo, Oriente, el 10 de octubre de 1968". www.granma.cubaweb.cu. Digital. Fecha de acceso 25 nov. 2013.

---. "Discurso pronunciado en el parque Céspedes de Santiago de Cuba, el 1 ro de enero de 1959". www.granma.cubaweb.cu. Digital. Fecha de acceso 26 nov. 2013.

---. La historia me absolverá. www.bureau.comandantina.com. Digital. Fecha de acceso 3 abr. 2014.

Castro Ruz, Raúl. "Discurso del General de Ejército Raúl Castro Ruz, ... en el acto de conmemoración del 55 Aniversario del triunfo de la Revolución. . .en Santiago de Cuba, el 1ro de enero de 2014". www.cubadebate.com. Digital. Fecha de acceso 3 mar. 2014.

Castromori, Javier de. "Iconografía cubana XXXIII: 'Oda a la Piña', reina de los campos de Cuba". Memorandum vitae 30 jul. 2013. Digital. Fecha de acceso 13 feb. 2014.

Cenesex. "Quiénes somos". Centro Nacional de Educación Sexual. www.cenesex.org. Digital. Fecha de acceso 15 mar. 2014.

Chacón y Calvo, José María. Ensayos de literatura cubana. Madrid: Ed. Saturnino Callejas, 1922. Impreso. 
Chatellus, Adélaide de. "Del cuento hispanoamericano a las formas breves en lengua castellana: hacia lo universal". Literatura más allá de la nación. De lo centrípeto y lo centrifugo en la narrativa hispanoamericana del siglo XXI. Madrid: Iberoamericana, 2011: 155-65. Impreso.

Chover Lafarga, Ana. El cuarto de Tula. Erotismo y sexualidad en las narradoras cubanas del Periodo Especial. Dis. Universitat de Valencia, 2010. Impreso.

Cicero, Arsenio R. Variantes de una posmodernidad: el caso cubano, mitos y narrativas. Dis. University of Wisconsin. 2011. Impreso.

Coelho, Pablo. Once minutos. Madrid: Planeta, 2010. Impreso.

Corradini, Mario: El buscador. Life Quality Project International. http://www.motivaciones.org/MOTIV003/ctoseelbuscador.htm. Digital. Fecha de acceso 12 nov. 2013.

Cortázar, Julio. "Carta de Julio Cortazar a Roberto Fernández Retamar - 10 de mayo de 1967”. http://www.autoreseditores.com/blog/2011/08/31/carta-de-juliocortazar-a-roberto-fernandez-retamar-10-de-mayo-de-1967/. Digital. Fecha de acceso 24 nov. 2013.

Cubanow. Isla de Letras: Anna Lidia Vega Serova, Octubre 18, 2012. Digital. Fecha de acceso 16 feb. 2014.

Cuesta, Mabel. Hacia un nuevo imaginario nacional: Narradoras cubanas de los noventas. Dis. City University of New York, 2011. New York: UMI 3481498, 2011. Impreso.

De Armas. Armando. "El lobo, la caperucita, Ena Lucía Portela y yo" Guaimaro. Belén institucional de la nación cubana. www.revistaguaimaro.blogspot.com.

Digital. Fecha de acceso 20 oct. 2013.

De la Nuez, Iván, ed. Cuba y el día después. Doce ensayistas nacidos con la revolución imaginan el futuro. Barcelona: Mondadori, 2001. Impreso.

---. La balsa perpetua. Soledad y conexiones de la cultura cubana. Barcelona: Casiopea, 1998. Impreso.

---. El mapa de sal. Un poscomunista en el paisaje global. Barcelona: Mondadori, 2001. Impreso.

De la Paz, Luis. "Celebrando a Virgilio Piñera, memorias de un congreso". www.elnuevoherald.com. 31 de agosto 2013. Digital. Fecha de acceso 22 oct. 2013. 
De la Riva, Juan Pérez. "La población de Cuba, la guerra de independencia y la inmigración del siglo XX”. Revista de la Biblioteca Nacional. 3er. Trimestre 1971: 17-27. Impreso.

Del Risco, Enrique. Elogio de la levedad: Mitos nacionales cubanos del siglo XX y sus reescrituras literarias. Dis. NYU, 2007. New York: UMI 3269778, 2007. Impreso.

Dettman, Jonathan. "El lobo, el bosque y el hombre nuevo. Una versión anotada para el estudiante de literatura". M.A.T. Spanish. Northern Arizona University. hamalweb.com.ar. Digital. Fecha de acceso 13 dic. 2013.

Díaz, Duanel. Los límites del origenismo. Madrid: Colibrí, 2005. Impreso.

---. Palabras del trasfondo. Intelectuales, literatura e ideología en la Revolución Cubana. Madrid: Colibrí, 2009. Impreso.

Díaz-Canel Bermúdez, Miguel. "Nosotros continuaremos adelante, conscientes de la fuerza que emana de la unidad y la fe en la justeza revolucionaria" (Discurso). Juventud Rebelde 10 ene. 2014. www.juventudrebelde.cu. Digital. Fecha de acceso 21 mar. 2014.

Diccionario del castrismo cotidiano. Códigos y lenguaje de la nomenklatura. www.cubanalisis.com. Digital. Fecha de acceso frecuente.

Dorfman, Ariel, y Armand Mattelart. Para leer al Pato Donald. Comunicación de masa y colonialismo. México D.F: Siglo XXI, 2005. Impreso.

Dorta Sánchez, Walfrido. "Discursos posnacionales, políticas de (des)autorización y terror-ismo literarios: la poesía no lírica de los escritores del grupo Diáspora(s) (fragmento)". www.gc-cuny.academia.edu. Digital. Fecha de acceso 6 mar. 2014.

---. 'Productividad ideológica y canonicidad: sobre 'La Ronda' de Manuel de Zequeira y Arango". LL Journal 7.2 (2012). Impreso.

Espinosa Chepe, Oscar. "La ofensiva revolucionaria de 1968, 44 años después. Cuando en Cuba se llegó a pensar en eliminar el dinero". Cubaencuentro 27 mar. 2012. www.cubaencuentro.com. Digital. Fecha de acceso 23 mar. 2014.

Esteban, Ángel, y Jesús Montoya Juárez. “¿Desterritorializados o multiterritorializados?: La narrativa hispanoamericana en el siglo XXI'. Literatura más allá de la nación. De lo centrípeto y lo centrífugo en la narrativa hispanoamericana del siglo XXI. Madrid: Iberoamericana, 2011: 7-13. Impreso. 
Ette, Omar. José Martí, apóstol, poeta, revolucionario. Una historia de su recepción. México: UNAM, 1995. Impreso.

Fauquié, Rafael. "Escribir la extrañeza: Jorge Luis Borges, José Lezama Lima". Espéculo. Revista de estudios literarios 29 (2005). Impreso.

Fernández Álvarez, Diego Emilio. “Cecilia Valdés”. Reseñas de zarzuelas, revistas, operetas y óperas españolas. lazarzuela.webcindario.com. Marbella, $15 \mathrm{de}$ febrero de 2010. Digital. Fecha de acceso 11 ene. 2014.

Fernández Busté, Julio. "La constitución de 1940 desde nuestra actual perspectiva". Honda 20 www.josemarti.cu. Digital: 1-7. Fecha de acceso 12 abr. 2014.

Fernández de Juan, Laidi. "La vida es mágica. Entrevista a Vega Serova. http://www.latinartmuseum.com/vega-.htm. Digital. Fecha de acceso 3 may. 2014.

Fernández Retamar, Roberto. “Entrevista”. Trilce 14 (1968): 40. Impreso.

---. Para una teoría de la literatura hispanoamericana. Bogotá: Publicaciones del Instituto Caro y Cuervo, 1995. Impreso.

Ferrán, Yamilé, y Maitheé Rodríguez. Luz y sombra de mujer. La Habana: Letras cubanas, 1998. Impreso.

Fornet, Jorge. Los nuevos paradigmas. Prólogo narrativo al siglo XXI. La Habana: Letras cubanas, 2006. Impreso.

Fowler, Víctor. La maldición: una historia del placer como conquista. La Habana: Letras Cubanas, 1998. Impreso.

Fuguet, Alberto y Sergio Gómez, ed. McOndo. Barcelona: Grijalbo Mondadori, 1996. 13. Impreso.

García Álvarez, Ibet. "Palabras sin velo de Helen Hernández Hormilla. Unión de Escritores y Artistas de Cuba 2 feb. 2014. www.uneac.org.cu. Digital. Fecha de acceso 12 may. 2014.

García Borrero, Juan Antonio. "Breve introducción al discurso audiovisual de la diáspora cubana”. Revista Surco Sur 1 (2010): 64-9. Impreso.

García Canclini, Néstor. "Introducción: La sociología de la cultura de Pierre Bourdieu”. Sociología y cultura. México, D.F.: Grijalbo, 1990: 1-23. Impreso. 
---. "Pensar en medio de la tormenta". Imaginarios de nación: pensar en medio de la tormenta. Bogota: Cuadernos de nación, 2001. Impreso.

García Hernández, Arturo. "La política cultural de Cuba, sin dogmas ni sectarismos. Entrevista con Abel Prieto, Ministro de Cultura de Cuba". La Jornada Invierno (2007). www.aerodigital.net. Digital. Fecha de acceso 23 dic. 2013.

García Ronda, Denia, et al. "Venturas y desventuras de la narrativa cubana actual". Temas 24-25 (2001): 166-192. Impreso.

Garrandés, Alberto. Cibersade. La Habana: Letras cubanas, 2002. Impreso.

---. La lengua impregnada. Fluencias libres sobre erotismo y sexualidad en la narrativa cubana contemporánea. La Habana: Letras cubanas, 2011. Impreso.

---. “Rapunzel”. Nosotras dos. La Habana: Unión, 2011: 73-90. Impreso.

---. "Su majestad Carlos Montenegro". Cuba La Gran Nación. Así somos. Mariana50 9 jun. 2010. www.cubalagrannacion.wordpress.com. Digital. Fecha de acceso 23 ago. 2013.

González, Aníbal. "Introducción”. Más allá de la nación en la literatura latinoamericana del Siglo XXI. Special Issue Revista de Estudios Hispánicos 46.1. (2012): 50-3. Impreso.

González Echevarría, Roberto. "Cien años de soledad cuarenta años después”. Otro Lunes. Revista Hispanoamericana de Cultura 4 (sept. 2008). www.otrolunes.com. Digital. Fecha de acceso 24 abr. 2014.

González Pagés, Julio César. Por andar vestida de hombre. La Habana: Editorial de la mujer, 2012. Impreso.

Grillo, Rafael. "Cecilia. De Villaverde a Solás". La Jiribilla 11. 22 al 28 de sept. 2012. http://www.lajiribilla.cu/2012/n594_09/594_02.html. Digital. Fecha de acceso en 13 de feb. 2014.

Guadarrama González, Pablo. "Enrique José Varona ante la condición humana". Anuario de Filosofia Argentina y Americana 18-19 (2001-2002):13-38. Impreso.

Guerra, Wendy. Ropa interior. Barcelona: Bruguera, 2009. Impreso.

Guerrero, Gustavo. "Literatura, nación y globalización en Hispanoamérica: explorando el horizonte post-nacional”. Revista de Estudios Hispánicos 46.1 (2012): 73-81. Impreso. 
Guevara de la Serna, Ernesto. "El socialismo y el hombre en Cuba". La Habana: Editora Política, 1988. Impreso.

Hart Dávalos, Armando. "José Martí: la tradición ética de la nación cubana". Escuela nacional de salud pública. www.ensap.sld.cu. Digital. Fecha de acceso en 23 mar. 2014.

Hens, Antonio. “Antonio Hens, La partida y por qué no puede haber futbolistas gays". La información.com 18 mar. 2014. noticias.lainformacion.com. Digital. Fecha de acceso 20 abr. 2014.

Henríquez Lagarde, Manuel. "Sexo, violencia y lenguaje de adultos". 37 (2002) www.lajiribilla.cu.. Digital. Fecha de acceso 19 jun. 2013.

Heredero, Liliet. "Las diez huellas soviéticas en Cuba". BBC Mundo América Latina 17 ago. 2011. www.bbc.co.uk.. Digital. Fecha de acceso 21 dic. 2013.

Heredia, José María: Niágara y otros textos: poesía y prosa selectas. Caracas: Biblioteca Ayacucho, 1990. Impreso.

---. "Desengaños". Niágara y otros textos: poesía y prosa selectas. Caracas: Biblioteca Ayacucho, 1990: 91-2. Impreso.

---. "Niágara”. en José María Heredia. La patria y la vida. Leonardo Padura. La Habana: Ediciones Unión, 2003: 136-41. Impreso.

Hernández Busto, Ernesto. “Entre tumbas y fantasmas. Una conversación con Rafael Rojas”. Letras libre 60 (2006). Impreso.

---. “Gastón Baquero: lo que no se dice”. Penúltimos días 26 de feb. 2009. www.penúltimosdias.com. Digital. Fecha de acceso feb. 122014.

Hernández Catá, Alfonso. El ángel de Sodoma. Google eBooks. www.google.com. Digital.

---. El sembrador de sal. Madrid: Publicaciones Prensa Gráfica, 1923. Edición facsímil. bibliotecadigital.jcyl.es. Digital. Consultado en abr. 52014.

Hernández, Cristina. "La diáspora se acerca a la isla”. La Jiribilla 18 al 24 feb. 2012. www.lajiribilla.cu. Digital. Fecha de acceso 5 may. 2014.

Hernández, Helen. "La literatura es un juego. Entrevista con Anna Lidia Vega Serova". La Jiribilla 24 al 30 may. 2008. www.lajiribilla.cu. Digital. Fecha de acceso 3 abr. 2014. 
Hernández, Rafael. "Huellas culturales rusas y de Europa del Este en Cuba". Panel de discusión realizado el 28 de mayo de 2009, en el Centro Cultural Cinematográfico ICAIC. Part. Rafael Hernández, Zoila Barash, Julio Cid, Dmitri Prieto Samsonov, Yoss. www.temas.cult.cu. Digital. Fecha de acceso 15 mar. 2014.

Hernández Salván, Marta. "A Requiem for a Chimera: Poetics of the Cuban PostRevolution". Revista de Estudios Hispánicos. 43.1. (2009): 149-70. Impreso.

Herring, Philip. Djuna Barnes. Barcelona: Circe, 1997. Impreso.

Hinkson, John. "Postmodernism and Structural Change". Public Culture 2.2 (1990): 82101. Impreso.

Hobsbawm, Eric J. “Identidad”. Revista internacional de filosofia política 3 (1994): 5-17. Impreso.

Hormilla, Helen H. "Enferma de optimismo. Entrevista con la narradora cubana Karla Suárez". La Jiribilla 18 al 24 feb. 2012. www.lajiribilla.cu. Digital. Fecha de acceso 7 may. 2014.

Instituto de Literatura y Lingüística de Cuba. Historia de la Literatura Cubana. La colonia: desde los orígenes hasta 1898. Tomo I. La Habana: Letras Cubanas, 2002. Impreso.

---. Historia de la Literatura Cubana. La Revolución (1959-1988). Con un apéndice sobre la literatura de los años noventa. Tomo III. La Habana: Letras Cubanas, 2008. Impreso.

---. Perfil histórico de las letras cubanas. Desde los orígenes hasta 1898. 2 T. La Habana: Editorial Félix Varela, 2006. Impreso.

Jiménez del Campo, Paloma. "Casa propia. El mundo narrativo de la cuentística cubana de Anna Lidia Vega Serova". Lejana. Revista Crítica de Narrativa Breve 5 (2012):1-13. www.lejana.elte.hu. Digital. Fecha de acceso 5 mar. 2014. Impreso.

Lacarra Lanz, Eukene. "Representaciones del homoerotismo femenino en algunos textos románicos". Atalaya. Revue d'études medievales romanes 12 (2011). atalaya.revues.org/674. Digital. Fecha de acceso 20 febr. 2014.

Lago González, David. "El Penthouse de Heriberto". heribertopenthouse.blogspot.com. Digital. 
Largacha Martínez, Carlos. "Identidad y memoria: La construcción de nación en América Latina”. Comunicación, cultura y política. Revista de ciencias sociales 1.2 (jul.dic. 2009): 86-94. Impreso.

Lateral. Revista de Cultura. "Manifiesto Crack" 70 (2000). www.lateraled.es/tema/070manifiestocrack.htm. Digital. Fecha de acceso 11 feb. 2014.

Lezama Lima, José, otros: Antología de la poesía cubana. Madrid: Verbum, 2012. Impreso.

---. Confluencias. La Habana: Letras Cubanas, 1988. Impreso.

---. Cronología bibliográfica. La Habana: Letras cubanas, 1998. Impreso.

---. "Prólogo a una antología". Letras. Cultura en Cuba 8. Ed. Ana Cairo Ballester. La Habana: Pueblo y Educación, 1997:337-63. Impreso.

Lidsky, Paul: Los escritores contra la comuna. México: Siglo XXI, 1971. Impreso.

Lobato Morchón, Ricardo. El teatro del absurdo en Cuba. 1948-1968. Madrid: Verbum, 2002. Impreso.

Lockwood, Lee. Castro's Cuba. Cuba's Fidel. London: Westview Press, 1990. Impreso.

López Cabrales, María del Mar. "Desde las entrañas del deseo homoerótico en Cuba" Confluencia 2005. Impreso.

López Corzo, Elizabeth. "Un boleto al paraíso para Gerardo Chijona. Entrevista a Gerardo Chijona". Unión de Escritores y Artistas de Cuba 17 mar. 2011. www.uneac.org.cu.. Digital. Fecha de acceso 23 mar. 2014.

López, Iraida H., ed. "Prólogo" El viejo, el asesino, yo y otros cuentos. Miami: Stockcero, 2009. Impreso.

Lloréns, Irma. Nacionalismo y literatura. Constitución e institucionalización de la "República de las letras cubanas". Lérida: Edicions de la Universitat de Lleida, 1998. Impreso.

López Cabrales, María del Mar: "Desde las entrañas del deseo homoerótico en Cuba. Ena Lucia Portela y Karla Suárez". Colorado State University. Confluencia, Spring (2005). Digital. Fecha de acceso 14 oct. 2013.

Luis Reyes, Dean. “Casal Recurrente”. Diario Juventud Rebelde 1ro. de julio de 2001. Impreso. 
---. "Pasando el trapo". www.uneac.org.cu. La isla en peso (2001). Digital. Fecha de acceso 19 abr. 2014.

Mandolessi, Silvana. “ ¿Es posnacional la literatura argentina contemporánea? Apuntes para un debate”. Mitologías hoy 1 (2011): 60-79. Impreso.

Mañach, Jorge. Luz y "El Salvador". La Habana: Academia de la Historia de Cuba, 1948. Impreso.

Marqués de Armas, Pedro. Ciencia y poder en Cuba. Racismo, homofobia, nación (17901970). Madrid: Verbum, 2014. Impreso.

Martí, José. Obras completas. La Habana: Ed. Lex, 1953. Impreso.

---. "Julián del Casal”. Letras. Cultura en Cuba 8. Ed. Ana Cairo Ballester. La Habana: Pueblo y Educación, 1997:225-26. Impreso.

Martínez Heredia, Fernando. "La formación del grupo de la calle K: Una filosofía para la Revolución cubana". La Jiribilla. www.lajiribilla.cu. 28 sept. al 8 oct. 2013. Digital. Fecha de acceso 5 dic. 2013.

Martínez-San Miguel, Yolanda, y Frances Negrón-Muntaner. "En busca de la 'Ana Veldford' de Lourdes Casal: exilio, sexualidad y cubanía". www.debatefeminista.com. Digital. Fecha de acceso 23 de may. 2014.

Mateo Palmer, Margarita. Ella escribía postcrítica. La Habana: Editora Abril, 2006. Impreso.

---. "La narrativa cubana contemporánea: las puertas del siglo XXI". Anales de Literatura Hispanoamericana 31 (2002): 51-64. Impreso.

Mattelart, Armand. Diversidad cultural y mundialización. Barcelona: Paidós, 2006. Impreso.

Memorias del subdesarrollo. Dir. Tomás Gutiérrez Alea. Act. Sergio Corrieri, Daisy Granados. ICAIC, 1968. Filme.

Méndez Martínez, Roberto. "Paradiso, cuarenta años". Preludio. Paradiso. La Habana: Letras Cubanas, 2009. Impreso.

Méndez y Soto, Ernesto. Panorama de la novela cubana de la revolución (1959-1970). Miami: Universal, 1977. Impreso. 
Menéndez. Ronaldo. "El gallo de Diógenes. Reflexiones en torno a lo testimonial en los novísimos narradores cubanos". Revista Encuentro de la cultura 18 (2000): 215-22. Impreso.

Minjarez Sesma, Solem. Humor, violencia y memoria nacional cubana. Aproximaciones a la narrativa breve de Aida Bahr, Marilyn Bobes y Ena Lucía Portela. Tesis. Arizona State University, 2012. Arizona: UMI, 2007. 1531180. Impreso.

Morales, Edel. "La invención de Rojas". La Jiribilla. www.lajiribilla.com. 32 (2001). Digital. Fecha de acceso 27 nov. 2013.

Morán, Francisco. Julián del Casal (in memoriam). Stockcero, 2012. Impreso.

---. Julián del Casal o los pliegues del deseo. Madrid: Verbum, 2008. Impreso.

---. "Nuestra historia. Surgimiento de La Habana Elegante". La Habana Elegante Segunda Época. www.lahabanaelegante.com. Digital. Fecha de acceso 12 mar. 2014.

Moraña, Mabel. Crítica impura. Estudios de literatura y cultura latinoamericanos. Madrid: Iberoamericana, 2004. Impreso.

Moray. Santos. "España y los primeros amores". www.mujeres.co.cu. Digital. Fecha de acceso 22 feb. 2014.

Muñoz, Gerardo. Revista Diáspora(s) 1. Edición facsímil. Linkgua digital, 2013. Google Book.

Newman, Britton W. The Presence and Function of Russia in the Fiction of José Manuel Prieto. Thesis. The University of North Carolina at Chapel Hill. 2008. Publication Number: 1454422. Impreso.

Noguerol Jiménez, Francisca, et al., eds. Literatura más allá de la nación. De lo centrípeto y lo centrífugo en la narrativa hispanoamericana del siglo XXI. Madrid: Iberoamericana, 2011. Impreso.

Novak, Dazra. Cuerpos Reservados. La Habana: Ediciones Unión, 2007. Impreso.

Olivera Córdova, Marielena. "Enqueernando la narrativa sáfica latinoamericana (apuntes)". Segundo Coloquio de Escrituras Sáficas 14 feb. 2013. www.academia.edu. Digital. Fecha de acceso 19 mar. 2014.

Opatrny, Josef. “José Antonio Saco y los Estados Unidos”. Revista Brasileira do Caribe 10.19 (2009): 79-104. Impreso. 
---. "La cubanidad y la nación cubana: José Antonio Saco y Martí". Centro de Estudios Ibero-Americanos. Universidad Carolina, Praga. www.mdc.ulpgc.es. Digital. Fecha de acceso 17 ene. 2014.

Ordoqui, Joaquín. "Las Cubas posibles: entrevista a Rafael Rojas" Revista Encuentro de la cultura 19 ene. 2001. www.cubaencuentro.com.. Digital. Fecha de acceso 5 may. 2013.

Oviedo, José Miguel. Historia de la Literatura Hispanoamericana. Madrid: Alianza Editorial, 2002. Impreso.

Padilla, Ignacio et al. "Manifiesto Crack". Lateral. Revista de Cultura. 70.1 (2000): 1-10. Impreso.

Padura, Leonardo. "De la falacia y sus alrededores". La falacia. Ed. Gerardo Fernández Fe. La Habana: Ediciones Unión, 1999. Impreso.

---. El hombre que amaba a los perros. Barcelona: Tusquets, 2011. Impreso.

---. José María Heredia. La patria y la vida. La Habana: Ediciones Unión, 2002. Impreso.

---. La neblina del ayer. Barcelona: Tusquets, 2009. Impreso.

Park, Jungwon. Imaginar sin frontera: Visiones errantes de nación y cosmopolitismo desde la periferia. Dis. University of Pittsburgh, 2008. Impreso.

Paz, Octavio. El laberinto de la soledad. México: Fondo de Cultura Económica, 1996. Impreso.

Pera, Cristóbal. “¿Nación? ¿Qué nación? La idea de América Latina en Volpi”. Revista de Estudios Hispánicos 46.1 (2012): 99-113. Impreso.

Perelló Cabrera, José. Compendio de indicadores económicos y turísticos de Cuba y el Caribe. La Habana: Universidad de la Habana. Centro de Estudios Turísticos (1ra. Versión), 2005. Impreso.

Pérez, Evelyn. Supuestas vidas. La Habana: Ediciones Unión, 2008. Impreso.

Pérez, Ladyrene, y Mónica Romero. "Miguel Barnet en inauguración del Congreso UNEAC: El mercado no puede dictar la política cultural". Cubadebate 11 abr. 2014. www.cubadebate.cu. Digital. Fecha de acceso 14 may. 2014. 
Pérez-Firmat, Gustavo. "A Willingness of the Heart: Cubanidad, Cubaneo, Cubanía" (1997). Cuban Studies Association Occasional Papers. Paper 8. www.scholarlyrepository.miami.edu/csa/8. Digital. Fecha de acceso $11 \mathrm{feb.}$ 2014.

Peri Rossi, Cristina. Cosmoagonías. Barcelona: Editorial Juventud, 1994. Impreso.

Picart, Gina. "Los nuevos paradigmas". Hija del aire www.ginapicart.wordpress.com. 24 jun. 2011. Digital. Fecha de acceso 12 feb. 2014.

Piñera, Virgilio. "En el insomnio". Cuentos fríos. Ed. Julio Travieso Serrano. México D.F.: Lectorum, 2006: 53. Impreso.

---. La isla en peso. The Whole Island. Ed. y trad. Mark Weiss. United Kingdom: Shearsman Books Ltd, 2010. Impreso.

Pollitt, Brian H. "The Cuban Sugar Economy and the Great Depression”. Bulletin of Latin American Research 3.2 (1984): 3-28. Impreso.

Ponte, Antonio José. La fiesta vigilada. Barcelona: Anagrama, 2007. Impreso.

---. "La lengua de Virgilio". El libro perdido de los origenistas. Madrid: Renacimiento, 2004. Impreso.

Portela, Ena Lucía. "Algunos rumores sobre Djuna y Daniel”. Piedepagina Revista de Libros 12 (ago. 2007). www.piedepagina.com. Digital. Fecha de acceso 10 abr. 2014.

---. Djuna y Daniel. Barcelona: Mondadori, 2008. Impreso.

---. Cien botellas en una pared. Barcelona: Mondadori, 2002. Impreso.

---. "Dos almas perdidas nadando en una pecera". XVII Encuentro Debate de Talleres Literarios de la Ciudad de La Habana. La Habana: Extramuros, 1990. Impreso.

---. "Una extraña entre las piedras". Una extraña entre las piedras. La Habana: Letras Cubanas, 1999: 91-122. Impreso.

---. La sombra del caminante. La Habana: Ediciones Unión, 2001. Impreso.

---. El viejo, el asesino, yo y otros cuentos. Ed. Iraida G. López. Miami: Stockcero, 2009. Impreso.

---. “Sombrío despertar del avestruz". Nosotros dos. Antología homoerótica femenina. La Habana: Ediciones Unión, 2011: 25-35. Impreso. 
Prieto, Abel. "Cultura, Cubanidad, Cubanía”. La Jiribilla 8 (2001). (http://www.lajiribilla.cu/2001/n8 junio/203 8.html.) Digital. Fecha de acceso 16 abr. 2013.

Puebla, Carlos. "La voz de Carlos Puebla". www.jukebox.es/carlos-puebla. Digital. Fecha de acceso 23 nov. 2013.

Quesada y Miranda, Gonzalo de. Martí hombre. La Habana: Seoane, Fernández y Co., 1944. Impreso.

Rafael, Luis. "Las fronteras de Anna Lidia Vega Serova". Otrolunes.com. Revista Hispanoamericana de Cultura Enero 2012. Digital. 23 nov. 2013.

Rama, Ángel. Transculturación narrativa en América Latina. México: Siglo XXI, 2004. Impreso.

Riccio, Alessandra. "Ena Lucía Portela: Presa y cazadora". La Jiribilla 37 (2002). www.lajiribilla.cu. Digital. Fecha de acceso 16 ene. 2014.

Riestra, Blanca. "Djuna y Daniel, Ena Lucía Portela". La Tormenta en un Vaso 25 sep. 2005. www.latormentaenunvaso.blogspot.com. Digital. Fecha de acceso 4 abr. 2014.

Rius Xirgú, Xavier. “137. Alfonso Hernández Catá”. www.margaritaxirgu.es. Digital. Fecha de acceso 13 mar. 2014

Rodríguez Coronel, Rogelio. La novela de la Revolución cubana (1959-1979). La Habana: Letras cubanas, 1986. Impreso.

---. "La obra narrativa de José Lezama Lima". Historia de la Literatura Cubana. La Revolución (1959-1988). Con un apéndice sobre la literatura de los años noventa. Tomo III. La Habana: Letras Cubanas, 2008: 201-7. Impreso.

Rodríguez Fernández, Aimara. Análisis axiológico de las obras de Enrique José Varona y Blas Infante. Tesis doctoral. Universidad de Granada, 2009. Granada, 2009. Impreso.

Rodríguez Sosa, Fernando. "Nosotras dos. Crítica”. www.uneac.org.cu. Digital. Fecha de acceso 5 abr. 2014.

Rojas, Marta. "Alma dividida”. Granma 25 de abril de 2008: 2. Impreso.

Rojas, Rafael. El arte de la espera: notas al margen de la política cubana. Madrid: Colibrí. 1998. Impreso. 
---. "Contra el homo cubensis: Transculturación y nacionalismo en la obra de Fernando Ortiz". Cuban Studies 35 (2004): 1-23. Impreso.

--- "Cultura e ideología en el poscomunismo cubano". Cuba: sociedad, cultura y política en tiempos de globalización. Ed. Mauricio de Miranda Parrondo. Cali: Pontificia Universidad Javeriana, 2003: 79-94. Impreso.

---. "El discurso de la frustración republicana en Cuba". 26 jun. 2013. http://bidi.unam.mx/libroe 2007/0708716/A22.pdf : 390-432.. Digital. Fecha de acceso 3 feb. 2014.

---. El estante vacio. Literatura y política en Cuba. Barcelona: Anagrama, 2009. Impreso.

---. "El intelectual y la revolución. Contrapunteo cubano del nihilismo y el civismo". Encuentro de la cultura cubana 16/17 (2000): 80-8. Impreso.

---. Isla sin fin. Contribución a la crítica del nacionalismo cubano. Miami: Universal, 1998. Impreso.

---. La máquina del olvido. Mito, historia y poder en Cuba. México: Taurus, 2011. Impreso.

---. La política del adiós. Miami: Universal, 2003. Impreso.

Rufinelli, Jorge. "Anna Lidia Vega Serova de San Petersburgo a la Habana, de las artes plásticas a la escritura". Nuevo Texto Crítico 21.41-42 (2008): 43-50. Impreso.

Said, Edward. Cultura e imperialismo. Barcelona: Anagrama, 1996. Impreso.

Sánchez Becerril, Ivonne. Erizar y divertir: el proyecto de escritura de Ena Lucía Portela. Dis. México: UNAM, 2011. Impreso.

Sánchez, Ivonne. "Según Karla Suárez, Ellos mienten". Seminario de Estudios sobre Narrativa Latinoamericana Contemporánea 1 sep. 2013. www.seminariodenarrativalatinoamericana.blogspot.com. Digital. Fecha de acceso 15 abr. 2014.

Santí, Enrico Mario. Bienes del siglo. Sobre cultura cubana. México D.F.: Fondo de Cultura Económica, 2002. Impreso.

Santos Lidia. "Novísimas y rarísimas: melodrama y experimentalismo en la narrativa cubana escrita por mujeres". Revista de Crítica Literaria Latinoamericana 31.62. (2005): 195-210. Impreso. 
Santos Moray, Mercedes. “España y los primeros amores”. www.mujeres.co.cu. Digital. Fecha de acceso 28 feb. 2014.

Semicz, Hanna O. "La formidable Djuna Barnes". Transtierros 30 mar. 2013. www.transtierros.blogspot.com. Digital. Fecha de acceso 19 abr. 2014.

Skodowska. Elzbieta. "La literatura cubana y su crítica en la época de la globalización". Romance Notes 50.1 (2010): 105-15. Impreso.

Sorel, Julián B. Nacionalismo y Revolución en Cuba. 1823-1998. Miami: Fundación Liberal José Martí, 1998. Impreso.

Suárez, Karla. Espuma. La Habana: Letras cubanas, 1999. Impreso.

---. Carroza para actores. La Habana: Ediciones Unión, 2011. Impreso.

---. "Carroza para actores". www.enfocarte.com 6.28 (2008). Digital. Fecha de acceso 6 feb. 2014.

---. "Fin de siglo". Entre los poros y las estrellas: selección de cuentos cubanos. La Habana: Editorial Abril, 2009. Impreso.

---. Silencios. La Habana: Letras cubanas, 2007. Impreso.

---. La viajera. Barcelona: Editorial Roca, 2005. Impreso.

Suárez y Romero, Anselmo. Costumbristas cubanos del siglo XIX. Anónimo. www.biblioteca.org.ar. Digital. Fecha de acceso 3 oct. 2014.

Suite Habana. Dir. Fernando Pérez. Act. Francisquito Cardet, Francisco Cardet, Norma Pérez. ICAIC, 2003. Documental.

Suquet Martínez, Mirta. "La hamaca o el tajo: Variantes para una narrativa de la identidad nacional". Convergencia 32 (2003). UAEM. México Anuarios $L / L$, edición especial, Instituto de Literatura y Lingüistica Cuba: 23-55. Impreso.

Tahbaz, Joseph. "Demystifying las UMAP: The Politics of Sugar, Gender, and Religion in 1960's Cuba". Delaware Review of Latin American Studies 14.2 (2013). www.udel.edu. Digital. Fecha de acceso 13 mar. 2014.

Thomas, Hugh. Cuba: la lucha por la libertad. Nueva York: Vintage, 2013. Impreso.

Tornés Reyes, Emmanuel. Ed. Entre los poros y las estrellas: selección de cuentos cubanos. La Habana: Casa Editora Abril, 2009. Impreso. 
Uxó, Carlos. "Los Novísimos cubanos: primera generación de escritores nacidos en la Revolución”. Letras Hispanas 7 (2011):186-98. Impreso.

Valdés Galarraga, Ramiro. Tres mujeres en la vida de José Martí. La Habana: Editora Política, 2012. Impreso.

Valle, Amir. Brevísimas demencias. La narrativa joven cubana de los 90. La Habana: Extramuros, 2001. Impreso.

Valladares Ruiz, Patricia. Subjetividades sexuales y nacionales en la narrativa cubana contemporánea (1990-2003). Montréal: Université de Montréal, 2004. Impreso.

Varela, Félix. Obras. Biblioteca Nacional de Cuba José Martí. Biblioteca Digital. www.ddigital.bnjm.cu. Digital. Fecha de acceso 5 oct. 2013.

Vargas Llosa, Mario. La verdad de las mentiras. Madrid: Alfaguara, 2003. Impreso.

Varona, Enrique José. Textos escogidos. México: Porrúa S.A., 1974. Impreso.

Vattimo, Gianni. El fin de la modernidad. Nihilismo y hermenéutica en la cultura posmoderna. Barcelona: Gedisa, 1987. Impreso.

Vega Serova, Anna Lidia. Ánima fatua. La Habana: Letras cubanas, 2008. Impreso.

---. El día de cada día. La Habana: Ediciones Unión, 2006. Impreso.

---. Eslabones de un tiempo muerto. Cienfuegos: Reina del mar editores, 2005. Impreso.

---. Imperio doméstico. La Habana: Letras cubanas, 2004. Impreso.

---. Limpiando ventanas y espejos. La Habana: Ediciones Unión, 2001. Impreso.

---. Mirada de reojo. La Habana: Ediciones Unión, 2010. Impreso.

---. Noche de ronda. La Habana: Ediciones Unión, 2003. Impreso.

Vitier, Cintio. Lo cubano en la poesía. La Habana: Instituto Cubano del Libro, 1970. Impreso.

---. Crítica 1. Obras. La Habana: Instituto Cubano del Libro, 2000. Impreso.

---. Ese sol del mundo moral. Para una historia de la eticidad cubana. México: Siglo veintiuno, 1975. Impreso. 
---. Poetas cubanos del siglo XIX. Semblanzas. La Habana: Instituto Cubano del Libro, 1969. Impreso.

Veiga González, Roberto. "La nación y la emigración ¿diálogo al inicio del camino? Palabra Nueva may. (2004). www.palabranueva.net. Digital. Fecha de acceso 12 feb. 2014.

Volpi, Jorge. El insomnio de Bolívar. Cuatro consideraciones intempestivas sobre América Latina en el siglo XXI. México: Mondadori, 2009. Impreso.

---. "El fin de la narrativa latinoamericana". Revista de Crítica Literaria Latinoamericana 59.1 (2004): 33-42. Impreso.

---. "Yo soy una novela". Nexos. www.nexos.com.mx. (mar. 2011): 50-4. Digital. Fecha de acceso 25 mar. 2014.

Weiss, Mark. Ed. y trad. La isla en peso. The Whole Island. United Kingdom: Shearsman Books Ltd, 2010. Impreso.

Willis, Angela L. "Una conversación franca con una escritora ruso-cubana que merece ser mejor conocida: Anna Lidia Vega Serova". The Latin Americanist Dec. 2013: 131-42. Impreso.

Yulzarí, Emilia. "Valoraciones sobre la obra de Ena Lucía Portela" Stockcero 2010. www.stockcero.com. Digital. Fecha de acceso 16 feb. 2014.

Žizek, Slavoj. El acoso de las fantasías. México: Siglo XXI, 1999. Impreso.

Zoppi Fontana, Mónica G. "En los márgenes del texto, intervalos de sentidos en movimiento". Páginas de Guarda 4 (2007): 11-39. Impreso.

Zubiaurre, Maite. Ed. "Prólogo". El ángel de Sodoma. Doral: Stockcero, 2011. Impreso. 
VITA

\section{RAUL CABRERA}

PLACE OF BIRTH: Havana, Cuba.

PROFESSIONAL HISTORY AND EDUCATION

FLORIDA INTERNATIONAL UNIVERSITY (Miami)

2010-Present

2014-Present

Spanish Ph.D. Doctoral Candidate

2010-2014

Adjunct Professor - Spanish

Teaching Assistant - Spanish

2009

CITY COLLEGE OF NEW YORK (NY)

Master of Arts in Spanish

2008-2009

Adjunct Professor - Spanish

NEW YORK CITY DEPARTMENT OF EDUCATION (NY)

$2007-2008$

Substitute Teacher - Spanish

ALLIANCE FRANCAISE DE CUBA (Havana, Cuba)

1997

Diplome de Traduction Supérieure

HIGHER INSTITUTE OF INTERNATIONAL RELATIONS (Havana, Cuba)

1990

Bachelor's Degree in International Relations and Affairs 